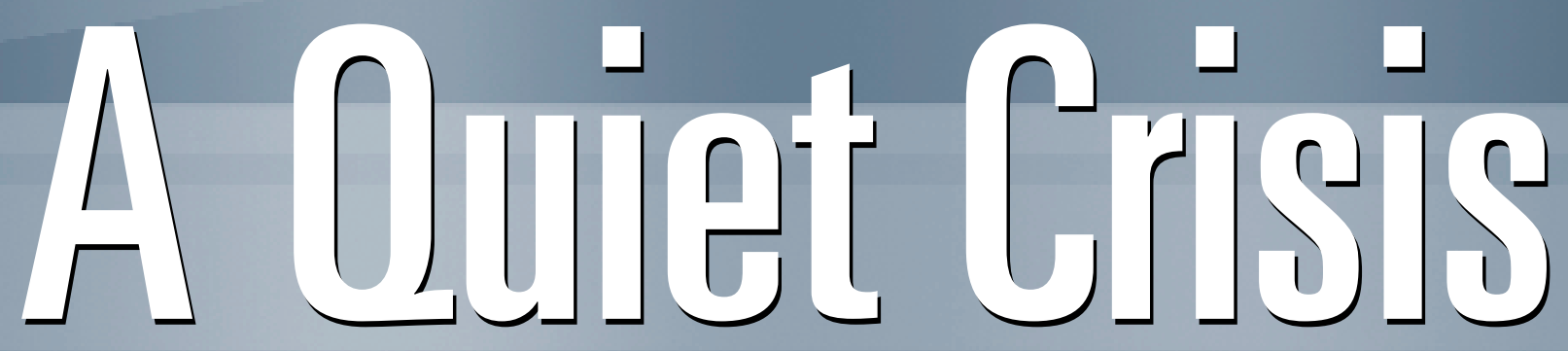

Fedlerad Funding and Undaset Negeds Is Jadian Countisy 


\section{U.S. Commission on Civil Rights}

The U.S. Commission on Civil Rights is an independent, bipartisan agency established by Congress in 1957. It is directed to:

- Investigate complaints alleging that citizens are being deprived of their right to vote by reason of their race, color, religion, sex, age, disability, or national origin, or by reason of fraudulent practices.

- Study and collect information relating to discrimination or a denial of equal protection of the laws under the Constitution because of race, color, religion, sex, age, disability, or national origin, or in the administration of justice.

- Appraise federal laws and policies with respect to discrimination or denial of equal protection of the laws because of race, color, religion, sex, age, disability, or national origin, or in the administration of justice.

- Serve as a national clearinghouse for information in respect to discrimination or denial of equal protection of the laws because of race, color, religion, sex, age, disability, or national origin.

- Submit reports, findings, and recommendations to the President and Congress.

- Issue public service announcements to discourage discrimination or denial of equal protection of the laws.

\section{Members of the Commission}

Mary Frances Berry, Chairperson

Cruz Reynoso, Vice Chairperson

Jennifer C. Braceras

Christopher Edley, Jr.

Peter N. Kirsanow

Elsie M. Meeks

Russell G. Redenbaugh

Abigail Thernstrom

Les Jin, Staff Director

U.S. Commission on Civil Rights

624 Ninth Street, NW

Washington, DC 20425

(202) 376-8128 voice

(202) 376-8116 TTY

www.usccr.gov 


\section{A Quiet Crisis}

Federal Funding and Unmet Needs in Indian Country 


\section{Letter of Transmittal}

The President

The President of the Senate

The Speaker of the House of Representatives

Sirs:

The United States Commission on Civil Rights transmits this report, A Quiet Crisis: Federal Funding and Unmet Needs in Indian Country, pursuant to Public Law 103-419. This report examines federal funding of programs intended to assist Native Americans at the U.S. Department of Interior, U.S. Department of Health and Human Services, U.S. Department of Housing and Urban Development, U.S. Department of Justice, U.S. Department of Education, and U.S. Department of Agriculture. In this report the Commission assesses the adequacy of funding provided via programs administered by these six agencies and the unmet needs that persist in Indian Country.

This study reveals that federal funding directed to Native Americans through programs at these agencies has not been sufficient to address the basic and very urgent needs of indigenous peoples. Among the myriad unmet needs are: health care, education, public safety, housing, and rural development. The Commission finds that significant disparities in federal funding exist between Native Americans and other groups in our nation, as well as the general population. Among immediate requirements for increased funding are: infrastructure development, without which tribal governments cannot properly deliver services; tribal courts, which preserve order in tribal communities, provide for restitution of wrongs, and lend strength and validity to other tribal institutions; and tribal priority allocations, which permit tribes to pursue their own priorities and allow tribal governments to respond to the needs of their citizens.

The Commission recommends that all federal agencies administering Native American programs identify and regularly assess unmet needs based on their authority. The federal government, through laws, treaties, and policies established over hundreds of years, is obligated to ensure that funding is adequate to meet these needs. Moreover, the government must work diligently to elevate the standard of living among Native Americans to that of other Americans by ensuring that federal agencies create attainable resource-driven goals toward this end.

For the Commissioners,

Mary Frances Berry

Chairperson 


\section{Acknowledgements}

This report was produced by the Office of Civil Rights Evaluation under the direction of Terri A. Dickerson, assistant staff director for civil rights evaluation. Principal writing and research were performed by Manuel Alba, social science analyst, and Mireille Zieseniss, civil rights analyst. Monique Dennis-Elmore, civil rights analyst, assisted with obtaining documents from agencies, performed research, and wrote several pages for the initial draft. Margaret Butler, civil rights analyst, assisted with calculations for inflation-adjusted dollars; Wanda Johnson, civil rights analyst, reviewed and commented on early drafts; and Teresa Brooks, secretary, sent the report to affected agencies for review. Library technician Vanessa Williamson provided valuable assistance in obtaining materials for the report and interns Jacqueline Pacheco, Hope College, Michigan; Adam Stella, Brown University, Rhode Island; and Alana Tipton, Springbrook High School, Silver Spring, Maryland, also contributed. Mr. Alba served as team leader.

The report was reviewed for legal sufficiency by Barbara de La Viez, attorney-advisor, Jenny Kim Park, attorney-advisor, and John W. Blakeley, attorney-advisor, Office of the General Counsel. John F. Dulles, director, Rocky Mountain Regional Office, Thomas V. Pilla, civil rights analyst, Western Regional Office, and John W. Blakeley, attorney-advisor, Office of General Counsel, reviewed the report for editorial aptness. Editor Dawn Sweet edited and prepared the report for publication. 


\section{Contents}

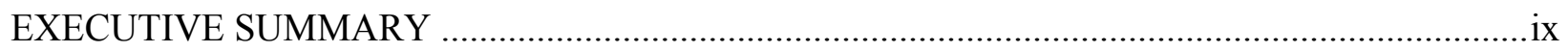

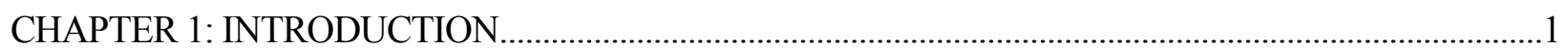

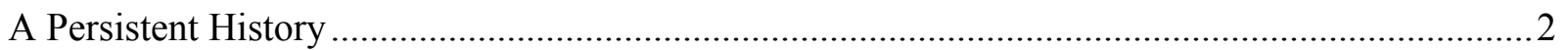

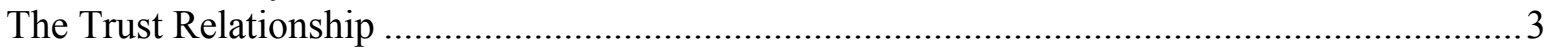

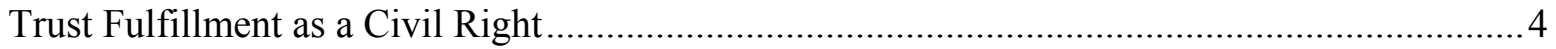

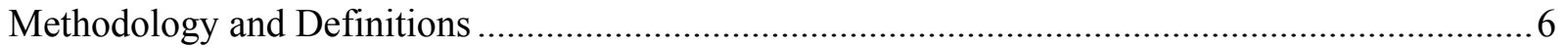

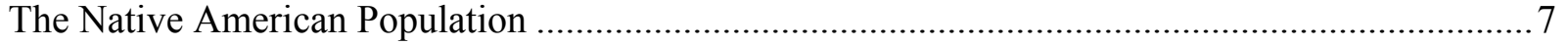

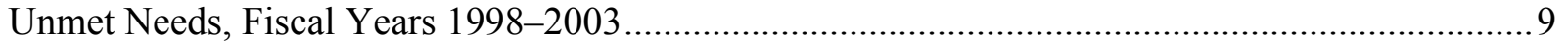

Federal Funding of Native American Programs ................................................................... 10

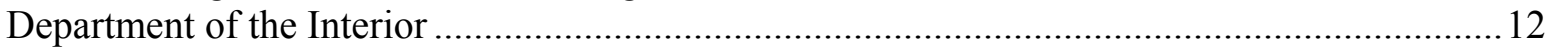

Department of Health and Human Services ....................................................................... 12

Department of Housing and Urban Development ............................................................. 13

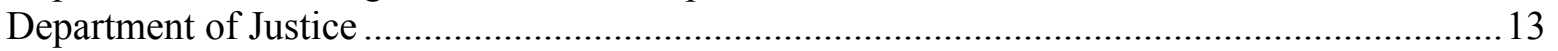

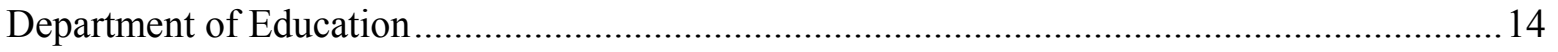

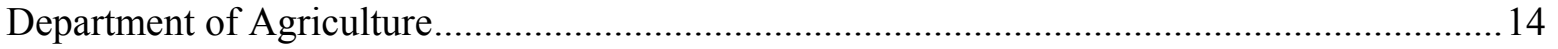

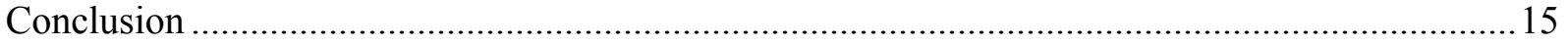

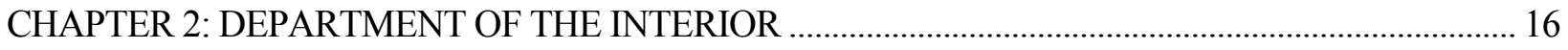

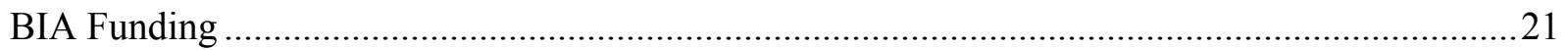

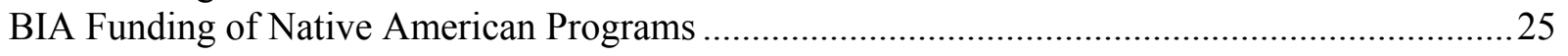

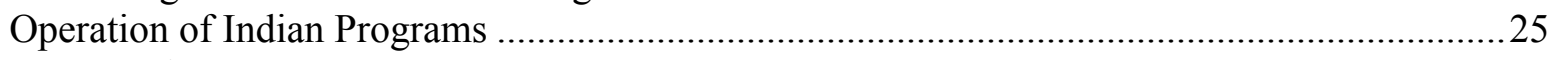

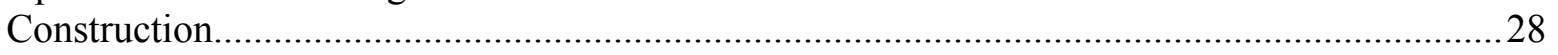

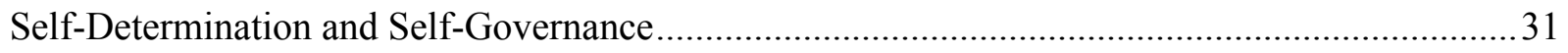

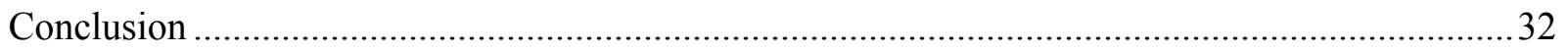

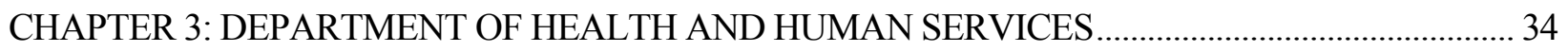

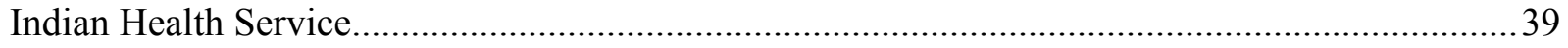

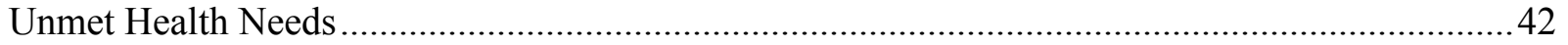

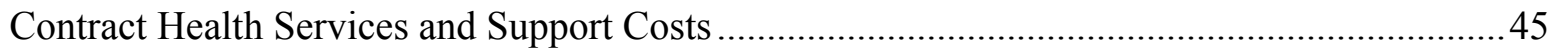

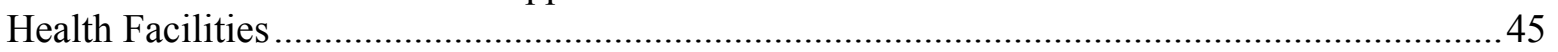

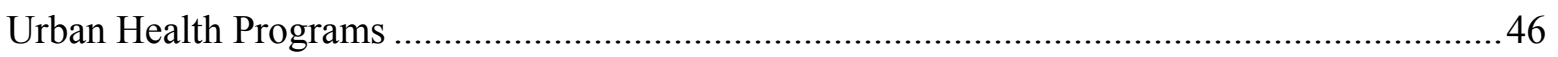

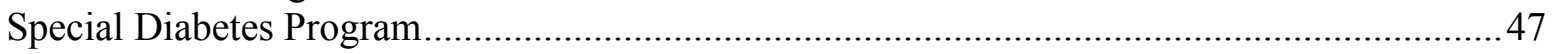

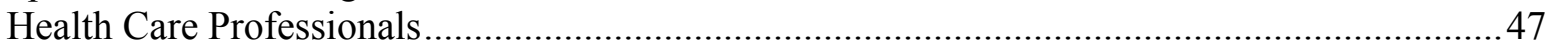

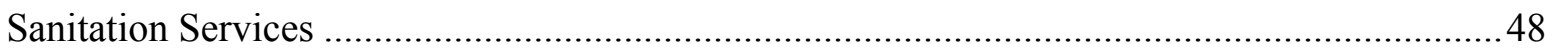

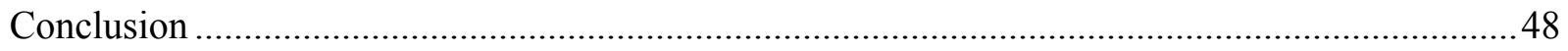

CHAPTER 4: DEPARTMENT OF HOUSING AND URBAN DEVELOPMENT .................................... 50

The Native American Housing Assistance and Self-Determination Act .....................................52

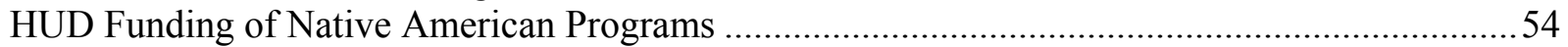

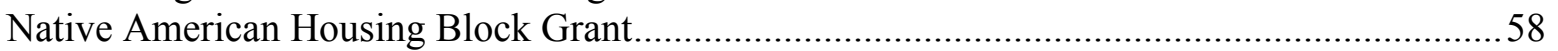

Title VI Tribal Housing Activities Loan Guarantee Program ...............................................58

Indian Home Loan Guarantee Program (Section 184) .............................................................59

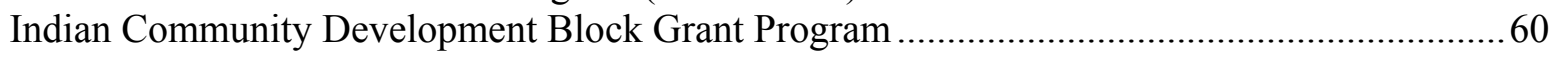

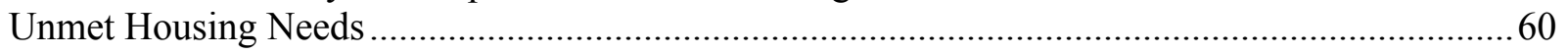

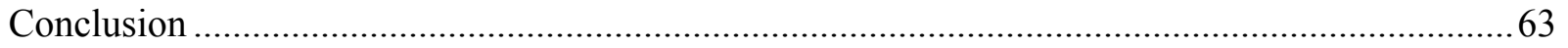




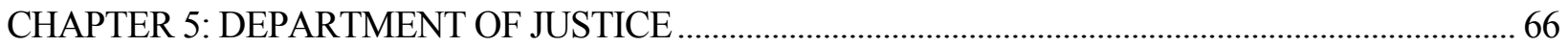

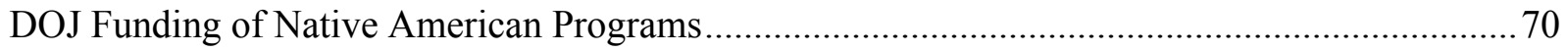

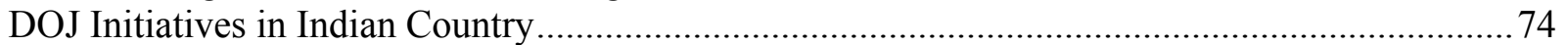

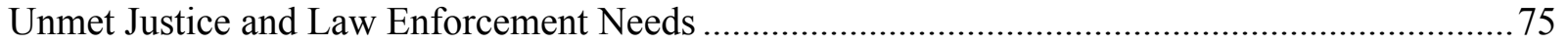

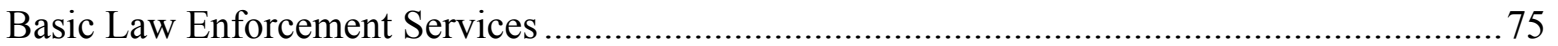

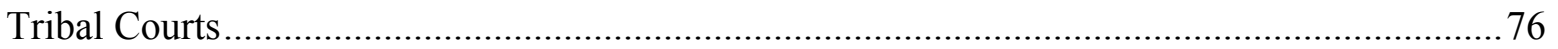

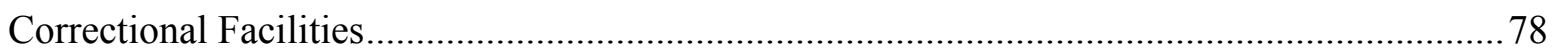

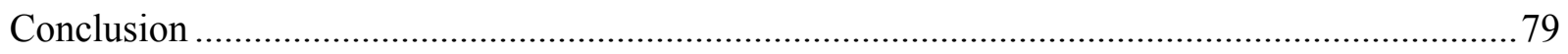

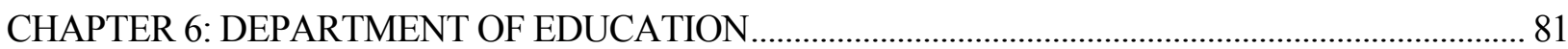

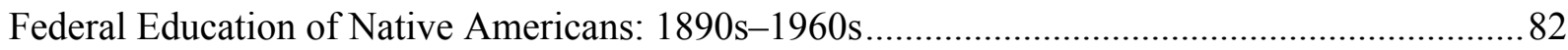

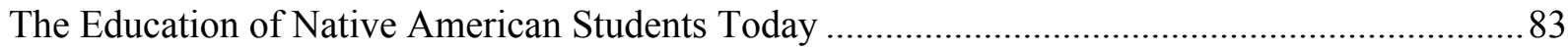

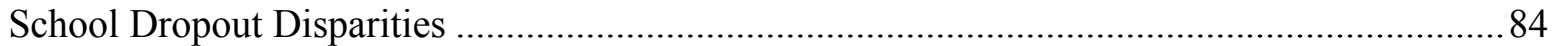

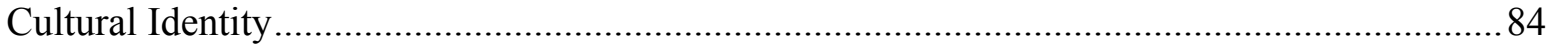

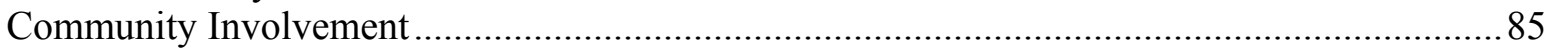

DOEd Funding of Native American Programs .................................................................... 85

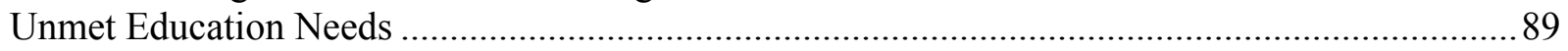

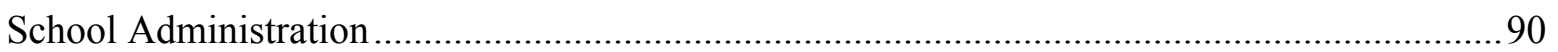

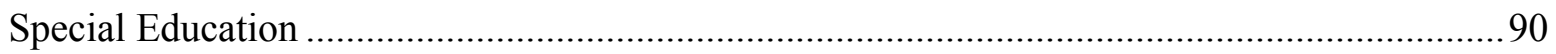

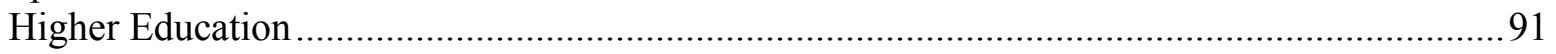

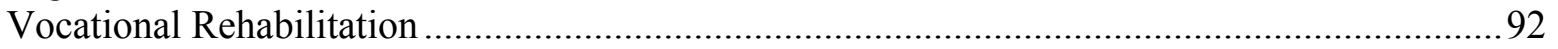

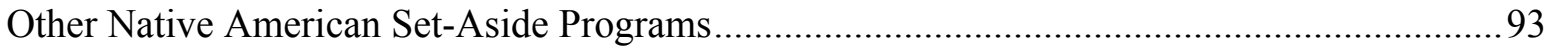

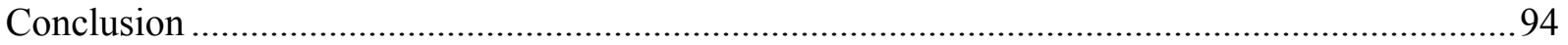

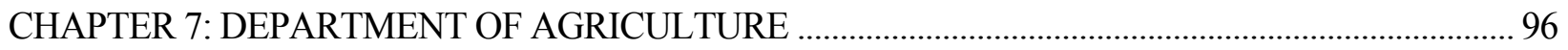

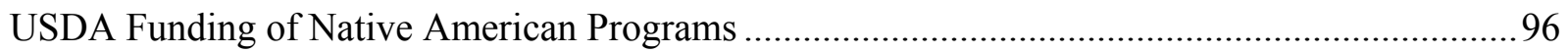

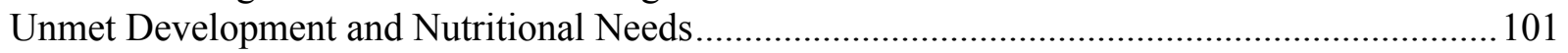

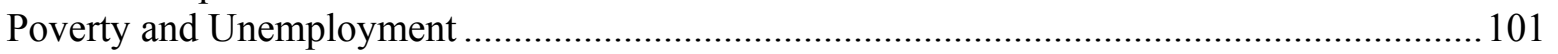

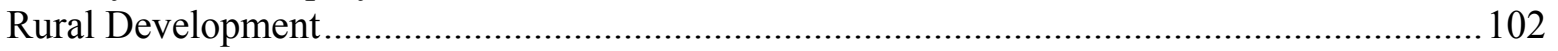

Food Distribution Program on Indian Reservations ............................................................. 104

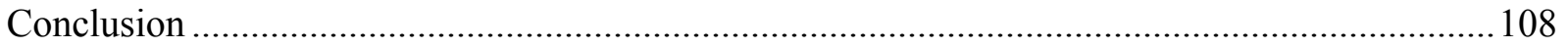

CHAPTER 8: CLOSING THE GAP_ADDRESSING UNMET NEEDS THROUGH FUNDING....... 110

The Growing Crisis: An Expression of Unmet Needs ............................................................ 110

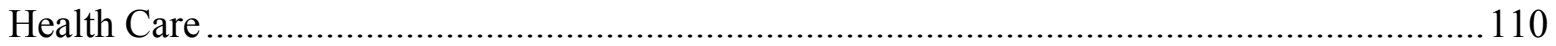

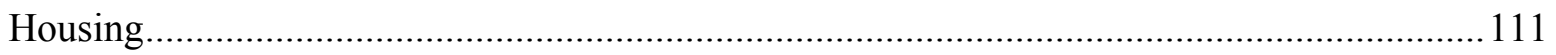

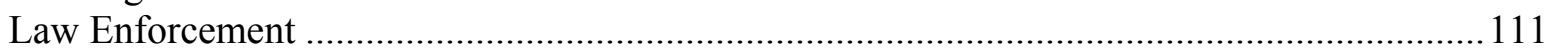

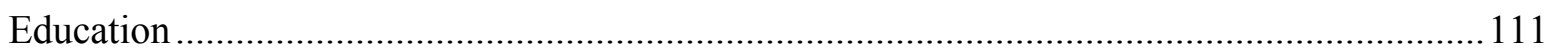

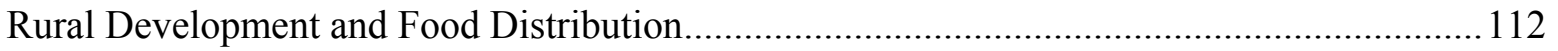

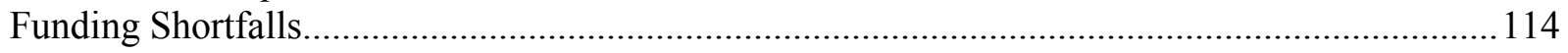

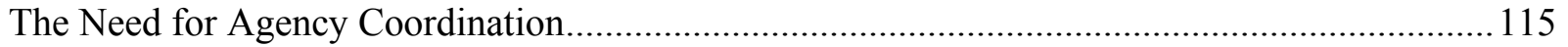

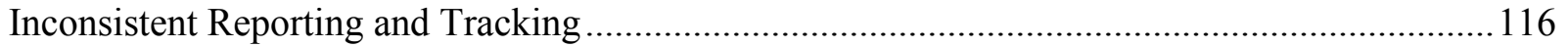

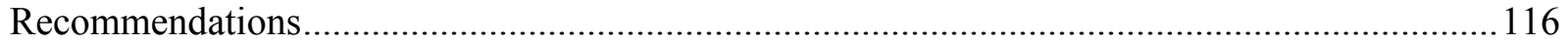

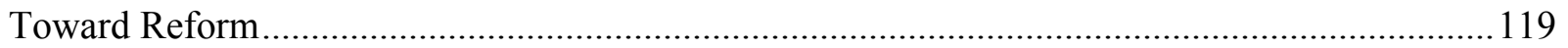

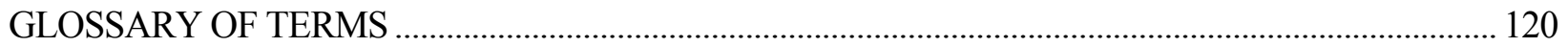




\section{FIGURES}

1.1 Actual and Constant Governmentwide Spending on Native American Programs, FY 1993-2003 .... 10

1.2 Per Capita Government Expenditures, U.S. Population vs. Native American Population, 1975-2000, in Current Dollars.................................................................................................. 11

3.1 HHS Budget Authority in Real and Constant Dollars, FY 1998-2004.....................................38

3.2 Comparison Between IHS Appropriations Per Capita and Other Federal

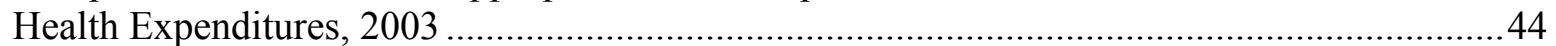

4.1 Comparison of Native American Appropriations and Disbursements, FY 1998-2002 ..............57

5.1 Organization Chart of Selected DOJ Offices Participating in Native American Programs ........70

7.1 Food Distribution Program on Indian Reservations Participation, FY 1998-2002 ..................107

\section{TABLES}

2.1 DOI Programs and Appropriations for BIA Services to Native Americans, FY 1998-2002 .......20

2.2 BIA Programs, Program Activities, and Subprograms ...................................................21

2.3 BIA Total Budget and as a Percentage of DOI's Discretionary Budget Authority, FY 1998-2004 ....22

2.4 Comparison of DOI and BIA Budgets in Constant 2003 Dollars, FY 1998-2004 _.................24

2.5 BIA Funding of Tribal Priority Allocations, FY 1998-2004 …..........................................27

2.6 BIA Funding of Education Construction, FY 1998-2004 …...................................................29

3.1 HHS Program Level Funding for American Indian and Alaska Native Programs, FY 1998-2004 .... 37

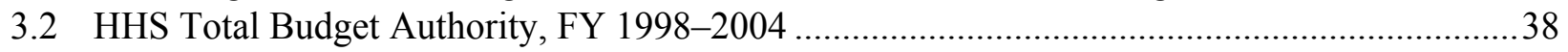

3.3 HHS Annual Discretionary Budget Authority, 1998-2003 …..............................................39

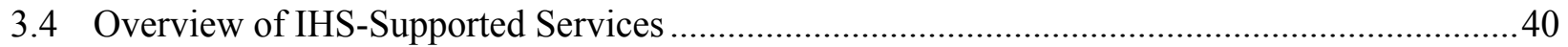

3.5 IHS Budget Authority as a Percentage of HHS Discretionary Authority ................................ 41

3.6 IHS Budget Authority and Program Level Funding, FY 1998-2003 .................................... 42

3.7 IHS Health Care Expenditures vs. Mainstream Benefits Package Expenditures, 2001 .............44

4.1 HUD Budget Authority, Discretionary Budget, and Native American Program Funding,

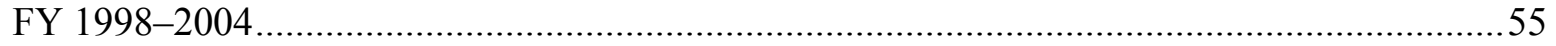

4.2 Native American Programs as a Percentage of HUD Appropriations, FY 1998-2004 ................55

4.3 HUD Budget Authority for Native American Programs, FY 1998-2004 ...............................56

4.4 Actual Disbursements of Native American/Native Hawaiian Grant Funds, FY 1998-2002 2..... 57

5.1 DOJ Budget Authority, Discretionary Budget, and Native American Program Funding,

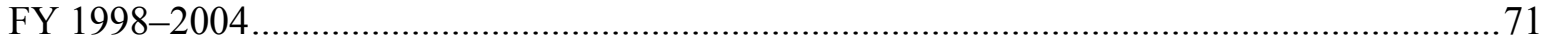

5.2 DOJ Funding for Native American Programs in Real and Constant 2003 Dollars, FY 1998-2004 .... 72

5.3 Native American Programs as a Percentage of Total OJP Funding, FY 1998-2004 .................72

5.4 DOJ Budget Authority for Native American Programs, FY 1998-2004 .................................73

5.5 Resources Available to Indian and Non-Indian Police Departments ....................................... 75

6.1A DOEd Appropriations for Office of Indian Education, FY 1998-2004 ..................................87

6.1B Office of Indian Education Program Funds as Percentage of DOEd Discretionary Funds,

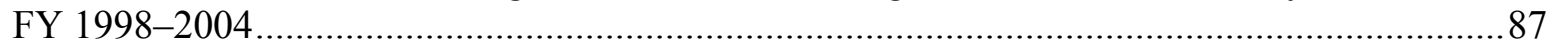

6.2 Office of Indian Education Subprograms Not Funded at Some Point During FY 1998-2004 .....88

6.3 Comparison of DOEd Discretionary Budget and Office of Indian Education Funding

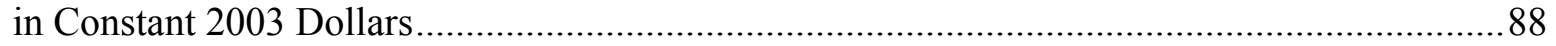

6.4 DOEd Funding of Select Native American Programs, FY 1998-2004 .................................91

6.5 DOEd Estimated Set-Asides Directly Supporting Native American Students, FY 2002-2004 ....94

7.1 USDA Funding of Programs Targeting Native Americans and Native American Institutions, FY 1999-2004. 
7.2 Native American Program Funding Relative to Total USDA Budget, FY 1999-2004 .............99

7.3 Native American Program Funding as a Percentage of Total USDA Budget, FY 1999-2004 ...... 100

7.4 Native American Set-Aside for Rural Community Advancement Program, FY 1999-2004 ... 102

7.5 Native American Set-Aside for Rural Community Advancement Program in Constant

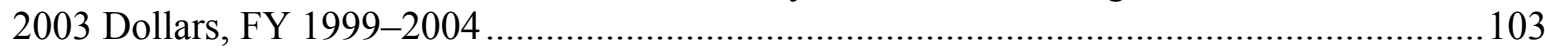

7.6 Food Distribution Program on Indian Reservations Funding Relative to Total Program Funding, FY 1999-2004 105

7.7 Food Distribution Program on Indian Reservations in Constant 2003 Dollars, FY 1999-2004.....106

8.1 Unmet Needs in Indian Country, by Agency ................................................................... 113 


\section{Executive Summary}

The federal government has a long-established special relationship with Native Americans characterized by their status as governmentally independent entities, dependent on the United States for support and protection. In exchange for land and in compensation for forced removal from their original homelands, the government promised through laws, treaties, and pledges to support and protect Native Americans. However, funding for programs associated with those promises has fallen short, and Native peoples continue to suffer the consequences of a discriminatory history. Federal efforts to raise Native American living conditions to the standards of others have long been in motion, but Native Americans still suffer higher rates of poverty, poor educational achievement, substandard housing, and higher rates of disease and illness. Native Americans continue to rank at or near the bottom of nearly every social, health, and economic indicator.

Small in numbers and relatively poor, Native Americans often have had a difficult time ensuring fair and equal treatment on their own. Unfortunately, relying on the goodwill of the nation to honor its obligation to Native Americans clearly has not resulted in desired outcomes. Its small size and geographic apartness from the rest of American society induces some to designate the Native American population the "invisible minority." To many, the government's promises to Native Americans go largely unfulfilled. Thus, the U.S. Commission on Civil Rights, through this report, gives voice to a quiet crisis.

Over the last 10 years, federal funding for Native American programs has increased significantly. However, this has not been nearly enough to compensate for a decline in spending power, which had been evident for decades before that, nor to overcome a long and sad history of neglect and discrimination. Thus, there persists a large deficit in funding Native American programs that needs to be paid to eliminate the backlog of unmet Native American needs, an essential predicate to raising their standards of living to that of other Americans. Native Americans living on tribal lands do not have access to the same services and programs available to other Americans, even though the government has a binding trust obligation to provide them.

In preparing this report, the Commission reviewed the budgets of the six federal agencies with the largest expenditures on Native American programs and conducted an extensive literature review.

\section{Department of the Interior}

The Bureau of Indian Affairs (BIA), within DOI, bears the primary responsibility for providing the 562 federally recognized Native American tribes with federal services. The Congressional Research Service found that between 1975 and 2000, funding for BIA and the Office of the Special Trustee declined by $\$ 6$ million yearly when adjusted for inflation.

BIA's mismanagement of Individual Indian Money trust accounts has denied Native Americans financial resources that could be applied toward basic needs that BIA programs fail to provide. Insufficient program funding resulted in $\$ 7.4$ billion in unmet needs among Native Americans in 2000. Of this amount, a shortfall in tribal priority allocations (TPA), which provides such basic services as child welfare and adult vocational training, alone totaled $\$ 2.8$ billion that year. Over the last few decades, Congress has minimally increased TPA funding. Unmet needs are also evident in school construction. In December 2002, the deferred maintenance backlog of BIA schools was estimated at $\$ 507$ million and increasing at an annual rate of $\$ 56.5$ million due to inflation and natural aging and 
deterioration of school buildings. BIA and its programs play a pivotal role in the lives of Native Americans, but mismanagement and lack of funding have undercut the agency's ability to improve living conditions in Native communities.

\section{Department of Health and Human Services}

Native Americans have a lower life expectancy than any other racial/ethnic group and higher rates of many diseases, including diabetes, tuberculosis, and alcoholism. Yet, health facilities are frequently inaccessible and medically obsolete, and preventive care and specialty services are not readily available. Most Native Americans do not have private health insurance and thus rely exclusively on the Indian Health Service (IHS) for health care. The federal government spends less per capita on Native American health care than on any other group for which it has this responsibility, including Medicaid recipients, prisoners, veterans, and military personnel. Annually, IHS spends 60 percent less on its beneficiaries than the average per person health care expenditure nationwide.

The IHS, although the largest source of federal spending for Native Americans, constitutes only 0.5 percent of the entire HHS budget. Moreover, it makes up a smaller proportion of HHS' discretionary budget today than five years ago. By most accounts, IHS has done well to work within its resource limitations. However, the agency currently operates with an estimated 59 percent of the amount necessary to stem the crisis. If funded sufficiently, IHS could provide more money to needs such as contract care, urban health programs, health facility construction and renovation, and sanitation services.

\section{Department of Housing and Urban Development}

The availability of safe, sanitary housing in Indian Country is significantly less than the need. Overcrowding and its effects are a persistent problem. Furthermore, existing housing structures are substandard: approximately 40 percent of on-reservation housing is considered inadequate, and one in five reservation homes lacks complete plumbing. Native Americans also have less access to homeownership resources, due to limited access to credit, land ownership restrictions, geographic isolation, and harsh environmental conditions that make construction difficult and expensive.

While HUD has made efforts to improve housing, lack of funding has hindered progress. Funding for Native American programs at HUD increased only slightly over the years (8.8 percent), significantly less than the agency as a whole (62 percent). After controlling for inflation, HUD's Native American programs actually lost spending power. The tribal housing loan guarantee program lost nearly 70 percent of its purchasing power over the last four years, and the Native American Housing Block Grant has lost funding for three years in a row. Given the unique housing challenges Native Americans face, greater and immediate federal financial support is needed.

Housing needs on reservations and tribal lands cannot be met with the same interventions that HUD uses to meet rental housing or homeownership goals in the suburbs or inner cities. Innovation and a more comprehensive approach are needed, and the government's trust responsibility to provide housing to Native Americans must be fully factored into these efforts.

\section{Department of Justice}

All three components of law enforcement-policing, justice, and corrections - are substandard in Indian Country compared with the rest of the nation. Native Americans are twice as likely as any 
other racial/ethnic group to be the victims of crime. Yet, per capita spending on law enforcement in Native American communities is roughly 60 percent of the national average. Correctional facilities in Indian Country are also more overcrowded than even the most crowded state and federal prisons. In addition, Native Americans have long held that tribal court systems have not been funded sufficiently or consistently, and hence, are not equal to other court systems.

Law enforcement professionals concede that the dire situation in Indian Country is understated. While DOJ should be commended for its stated intention to meet its obligations to Native Americans, promising projects have suffered from inconsistent or discontinued funding. Native American law enforcement funding increased almost 85 percent between 1998 and 2003, but the amount allocated was so small to begin with that its proportion to the department's total budget hardly changed. Native American programs make up roughly 1 percent of the agency's total budget. A downward trend in funding has begun that, if continued, will severely compromise public safety in Native communities.

Additionally, many Native Americans have lost faith in the justice system, in part due to perceived bias. Many attribute disproportionately high incarceration rates to unfair treatment by the criminal justice system, including racial profiling, disparities in prosecution, and lack of access to legal representation. Solving these problems is vital to restoring public safety and justice in Indian Country.

\section{Department of Education}

As a group, Native American students are not afforded educational opportunities equal to other American students. They routinely face deteriorating school facilities, underpaid teachers, weak curricula, discriminatory treatment, outdated learning tools, and cultural isolation. As a result, achievement gaps persist with Native American students scoring lower than any other racial/ethnic group in basic levels of reading, math, and history. Native American students are also more likely to drop out. The lack of educational opportunities in Native communities extends to postsecondary and vocational programs. Special Programs for Indian Adults has not been funded since 1995, and vocational rehabilitation programs are too poorly funded to meet the abundant need. Although 14 applications for such programs were submitted in 2001, only five tribal organizations received funding. Tribal colleges and universities receive 60 percent less federal funding per student than other public community colleges.

The federal government has sole responsibility for providing education to these students - an obligation it is failing to meet. Funding for DOEd's Office of Indian Education (OIE) has remained a relatively small portion of the department's total discretionary budget (ranging from 0.2 to 0.3 percent) between 1998 and 2003. OIE funding has undergone several reductions over the last few decades and, in many years, its budget has failed to account for inflation. At no time during the period under review in this report have all OIE subprograms been funded.

\section{Department of Agriculture}

The USDA is largely responsible for rural development and farm and business supplements in rural communities. Native Americans rely on such programs to foster conditions that encourage and sustain economic investments. However, insufficient funding has limited the success of development programs and perpetuated unstable economies. Poor economic conditions have resulted in food shortages and hunger. Native Americans are more than twice as likely as the general population to face hunger and food insecurity at any given time. The inaccessibility of food and economic devel- 
opment programs compromises their usefulness. By its failure to make programs accessible to Native Americans, the federal government has denied them the opportunity to receive benefits routinely available to other citizens.

USDA's set-aside for the Rural Community Advancement Program fluctuated between 2000 and 2003. The 2004 budget proposes to reduce funding by more than 18.2 percent from 2003 . The Food Distribution Program on Indian Reservations (FDPIR) lost funding when accounting for inflation (2.8 percent) between 1999 and 2003, reducing available food resources. FDPIR alone is not meeting the food assistance needs of Native Americans since many participants are also enrolled in other food assistance programs. The continuously high rates of hunger and poverty in Native communities are the strongest evidence that existing funds are not enough.

\section{Conclusion}

In short, the Commission finds evidence of a crisis in the persistence and growth of unmet needs. The conditions in Indian Country could be greatly relieved if the federal government honored its commitment to funding, paid greater attention to building basic infrastructure in Indian Country, and promoted self-determination among tribes.

The Commission further finds that the federal government fails to keep accurate and comprehensive records of its expenditures on Native American programs. There is no uniform reporting requirement for Native American program funding, and because agencies self-report their expenditures, available information varies across agencies, rendering monitoring of federal spending difficult.

While some agencies are more proficient at managing funds and addressing the needs of Native Americans than others, the government's failure is systemic. The Commission identified several areas of jurisdictional overlap, inadequate collaboration, and a lack of articulation among agencies. The result is inefficiency, service delay, and wasted resources. Fragmented funding and lack of coordination not only complicate the application and distribution processes, but also dilute the benefit potential of the funds.

In this study, the Commission has provided new information and analyses in the hope of stimulating resolve and action to address unmet needs in Indian Country. Converting data and analyses into effective government action plans requires commitment and determination to honor the promises of laws and treaties. Toward that end, the Commission offers 11 recommendations, which if fully implemented will yield (1) a thorough and precise calculation of unmet needs in Indian Country; (2) increased efficiency and effectiveness in the delivery of services through goal setting, strategic planning, implementation, coordination, and measurement of outcomes; (3) perennial adequate funding; and (4) advancement of Indian nations toward the goal of independence and self-governance.

Failure to act will signify that this country's agreements with Native people, and other legal rights to which they are entitled, are little more than empty promises. Focused federal attention and resolve to remedy the quiet crises occurring in Indian Country, embodied in these recommendations and the results that flow from them, would signal a decisive moment in this nation's history. That moment would constitute America's rededication to live up to its trust responsibility for its Native people. Only through sustained systemic commitment and action will this federal responsibility be realized. 


\section{Recommendations}

1. The Native American crisis should be addressed with the urgency it demands. The administration should establish a bipartisan, action-oriented initiative at the highest level of accountability in the government, with representatives including elected officials, members of Congress, officials from each federal agency that funds programs in Indian Country, tribes, and Native American advocacy organizations. The action group should be charged with analyzing the current system, developing solutions, and implementing positive change.

2. All agencies that distribute funds for Native American programs should be required to regularly assess unmet needs, including gaps in service delivery, for both urban and rural Native individuals. Agencies should establish benchmarks for the elevation of Native American living conditions to those of other Americans. Agencies should document Native American participation in programs and catalog initiatives.

3. Agencies should replicate IHS' Federal Disparity Index assessment for tracking disparities in services and needs. Tribal organizations and Native American advocacy groups should be consulted when agencies develop measures. The results of such examinations should be used to prepare budget estimates, prioritize spending, and assess the status of programs. Congress should require and review unmet needs analyses annually as a component of each agency's budget justification.

4. All federal agencies that administer Native American programs should be required to set aside money for infrastructure building that will benefit all. Such a fund should be jointly managed by the BIA, representatives from each contributing agency, and a coalition of tribal leaders. The contributing agencies should develop memoranda of understanding and other formal coordination mechanisms that outline precisely how the money will be spent.

5. Federal agencies should avoid implementing across-the-board budget cuts when the effect on already underfunded Native American programs is so severe. Agencies must prepare budgets that account for the proportionality of Native American funding.

6. Native American programs should be situated within the federal agencies that have the requisite expertise, but agencies should continually improve processes for redistributing funds to other agencies or tribal governments. Funds for a common purpose should be consolidated within a single agency so there is less overlap and clearer accountability.

7. To the extent possible, programs for Native Americans should be managed and controlled by Native Americans. Distribution of funds to tribes should be closely monitored by the source agencies to ensure that funds are used as directed in a manner developed in consultation with Native Americans and tribal governments.

8. Federal appropriations must compensate for costs that are unique to tribes, such as those required to build necessary infrastructure, those associated with geographic remoteness, and those required for training and technical assistance. The unique needs of non-reservation and urban Native Americans must also be assessed, and adequate funding must be provided for programs to serve these individuals.

9. Congress should request an analysis of spending patterns of every federal agency that supports Native American programs, either by the U.S. General Accounting Office or the Congressional Research Service. In addition, an independent external contractor should audit fund management of all federal agencies distributing Native American appropriations. 
10. Each agency should have one central office responsible for oversight and management of Indian funds, and which prepares budgets and analyses that can be compared and aggregated across agencies.

11. The Office of Management and Budget should develop governmentwide, uniform standards for tracking and reporting spending on Native American programs. Agencies should be required to include justifications for each Native American project in annual budget requests, as well as justifications for the discontinuation of such programs. They should also be required to maintain comprehensive spending logs for Indian programs, including actual grant disbursements, numbers of beneficiaries, and unfunded programs. 


\section{Chapter 1: Introduction}

There are at least two rationales for ongoing federal commitments to allocate resources to [American Indian/Alaska Native] programs and services. The first is a fundamental desire by the U.S. to address the compelling and often Third World conditions found in many native communities. . . I In many parts of native America, economic and social conditions resemble the emergency states associated with natural disasters which require federal intervention. The second rationale ... is the unique legal and political relationship between the U.S. and Indian tribes nationwide. ${ }^{1}$

The federal obligation to Native Americans is a matter of both moral and legal imperative. ${ }^{2}$ For centuries, Native Americans ceded or were displaced from culturally and historically vital territories on the agreement that the federal government would, in perpetuity, assume trust responsibility for them. ${ }^{3}$ The United States' authority and obligation to provide programs and services to Native Americans have long been established in laws, treaties, jurisprudence, and the customary practices of nations. Although Congress originally established treaties with various indigenous nations to meet the federal government's trust obligations to Native Americans, more recent laws also augment "Indian selfdetermination" by linking it with services. ${ }^{4}$ As this report will demonstrate, however, federal funding for services purported to compensate Native peoples for their sacrifices is unequal to the task. The

\footnotetext{
${ }^{1}$ Senator Ben Nighthorse Campbell, chair, and Senator Daniel K. Inouye, vice chair, Senate Committee on Indian Affairs, letter to the Senate Committee on the Budget, Feb. 29, 2000, as reported in Concurrent Resolution on the Budget, FY 2001, Report of the Committee on the Budget, United States Senate, Mar. 31, 2000, p. 188 (hereafter cited as Senators Campbell and Inouye, letter to the Senate Committee on the Budget, Feb. 29, 2000).

2 Throughout this report, the term "Native American" is used in lieu of "American Indian" or other terminology when not specifically citing or paraphrasing other work. It should be understood to include Alaska Natives unless otherwise noted. Unless otherwise indicated, Native Hawaiians are not included in the Native American category because they are not recognized as having the same government-to-government relationship, and are thus not eligible for the federal programs available to other Native groups. The term "Indian Country" refers to geographic regions encompassing reservations and trust lands within which Indian laws and customs and federal laws relating to Indians govern. See Theodore H. Haas, chief counsel, United States Indian Service, The Indian and the Law (Lawrence, KS: Haskell Institute, June 1949), p. 15, $<$ http://thorpe.ou.edu/cohen/tribalgovtpam2ptl\&2.htm>.

${ }^{3}$ See Senator Ben Nighthorse Campbell, chair, and Senator Daniel K. Inouye, vice chair, Senate Committee on Indian Affairs, letter to the Senate Committee on the Budget, Mar. 1, 2002, as reported in Concurrent Resolution on the Budget, FY 2003, Report of the Committee on the Budget, United States Senate, Apr. 11, 2002, p. 121 (hereafter cited as Senators Campbell and Inouye, letter to the Senate Committee on the Budget, Mar. 1, 2002); Tex Hall, president, National Congress of American Indians, testimony before the Senate Committee on Indian Affairs, Feb. 26, 2003 (hereafter cited as Hall testimony).

${ }^{4}$ Some of these laws are the Indian Reorganization Act of 1934, ch. 576, 48 Stat. 984 (codified as amended at 25 U.S.C. $\S$ 461-479 (1994 \& Supp. IV 1998)); Indian Civil Rights Act of 1968, Pub. L. No. 90-284, 82 Stat. 77 (codified as amended at 25 U.S.C. $\S \S 1301-1341$ (1994 \& Supp. IV 1998)); Indian Education Act of 1972, Pub. L. No. 992-318, 86 Stat. 873 (codified as amended in scattered sections of 7, 12, 16, and 20 U.S.C.); Indian Self-Determination and Education Assistance Act of 1975, Pub. L. No. 93-638, 88 Stat. 2206 (codified as amended in scattered sections of 5 U.S.C. and 25 U.S.C.); and American Indian Religious Freedom Act of 1978, Pub. L. No. 95-341, 92 Stat. 469 (codified as amended at 42 U.S.C. $\S 1996$ (Supp. IV 1998)). See also U.S. Department of the Interior, Office of Budget, "Bureau of Indian Affairs," FY 1998 Budget, $<$ http://www.doi.gov/budget/1998/BIAsum.html>; "Bureau of Indian Affairs," 2000 Department of the Interior Budget, $<$ http://www.doi.gov/budget/2000/index_for_2000.html>, p. BH-67. Self-determination is promoted via contracts, grants, or self-governance compacts, all of which provide Native Americans with greater authority in running programs.
} 
current federal funding of Native American programs is tethered to and built upon a past in which federal obligation to Native Americans was clearly established.

\section{A Persistent History}

Dating back to the country's earliest days, indigenous peoples have suffered gross injustices because of government-sanctioned policies. ${ }^{5}$ The birth of the nation rested upon the "discovery" and annihilation of its original inhabitants. Forty years before Christopher Columbus' voyage, Pope Nicholas V issued a law declaring war against non-Christians worldwide. The law allowed and promoted the conquest, colonization, and exploitation of non-Christian nations. In 1493, the year after Columbus returned, Pope Alexander VI issued a law granting Spain dominion over all lands that Columbus had located (except those previously located by Christian nations).

In 1823, a unanimous Supreme Court drew upon these church laws and the practice of European nations to establish how America would regard its indigenous peoples. In Johnson v. McIntosh the Court decided that when the United States became a successor nation, it retained the ultimate dominion European explorers had established over America. Thus, the conquest of indigenous peoples was justified as a right of discovery and was one of the bases on which the nation's early laws and policies were built. ${ }^{6}$ Consequently, the indigenous peoples lost the right to complete sovereignty, although they were not entirely dispossessed of land and retained the right to occupy and use the land. ${ }^{7}$ The United States, however, retained title to the land they inhabited, which precluded Native Americans from transferring it to any party other than the U.S. government.

A few years later, the government began to redefine its relationship with Native tribes. A series of Supreme Court cases in the 1830s established the analytical framework upon which Indian law is based today. Cherokee Nation v. Georgia determined that tribes are not foreign nations but rather "domestic dependent nations." 8 This decision forms the basis of what is now known as the trust relationship between tribes and the federal government and the consequent fiduciary responsibilities of the United States. In Worcester v. Georgia the Court recognized the self-governing status of tribes and refused to allow state law to be applied within tribal nations; it held that Indian tribes, as distinct political entities, are guaranteed protection against interference from the states. ${ }^{9}$

Despite this recognition of the inherent sovereignty of tribal governments, of their right to co-exist alongside Euro-Americans, Native peoples have nonetheless been subject to enduring efforts to strip them of their land, their possessions, and even their identities. Throughout the United States, Native peoples were pressured to lose their "Indianness," and to become individuals with no ties beyond family and, consequently, no claims to land or to the rights entered into by treaty with the federal government. ${ }^{10}$ For instance, the Cherokee were stripped of their lands, which once consisted of pre-

\footnotetext{
5 Lorie Graham, "Indigenous Peoples: Reparations and the Indian Child Welfare Act," Legal Studies Forum, vol. 25 (2001), p. 619 (hereafter cited as Graham, "Indigenous Peoples”).

${ }^{6} 21$ U.S. (8 Wheat.) 543 (1823).

${ }^{7}$ Johnson v. McIntosh, 21 U.S. (8 Wheat.) 543, 574 (1823).

${ }^{8} 30$ U.S. (5 Pet.) 1, 17 (1831).

${ }^{9} 31$ U.S. (6 Pet.) 515, 561 (1832).

${ }^{10}$ Ruth Wallis Herndon and Ella Wilcox Sekatau, "The Right to a Name: The Narragansett People and Rhode Island Officials in the Revolutionary Era," in American Encounters: Natives and Newcomers from European Contact to Indian Removal, 1500-1850, ed. Peter C. Mancall and James H. Merrell (NY: Routledge, 2000), p. 439 (hereafter cited as Herndon and Sekatau, "The Right to a Name").
} 
sent-day Kentucky and Tennessee, and were finally removed entirely from their homeland in $1838 .{ }^{11}$ In the $1880 \mathrm{~s}$, the state of Rhode Island declared the Narragansett people "extinct" and stripped the once-vibrant community of its tribal status; this denial of identity continues today. ${ }^{12}$

\section{The Trust Relationship}

The dispossession of Native peoples from their lands, in conjunction with the decimation of game and other foodstuffs, during the 18th, 19th, and 20th centuries denied them their primary method of sustenance, the freedoms enjoyed by other groups in the United States, and basic civil rights. Agreements between Native Americans and the United States came at a high price for Native peoples - a price they are still paying. The special government-to-government relationship, or trust relationship, between Native Americans and the United States that has evolved is upheld by the U.S. Constitution, as well as numerous Supreme Court decisions, treaties, and legislation. For example, binding agreements between the Cherokee Nation and the United States stipulate what the government owes the Cherokee today and henceforth for surrendering their land and all associated benefits, including access privileges and resources. ${ }^{13}$

In short, the federal government has obligations to tribes on the basis of agreements and treaties that were established when tribes relinquished their lands in exchange for services and other protections. The federal government, as trustee, thus has a responsibility to protect tribal lands, and holds title to ensure against their divestiture from tribal governments. ${ }^{14}$ Three components define the trust relationship: land, self-governance, and social services. According to the American Indian Policy Review Commission, the most important aspect of the trust relationship is its potential to improve the welfare of Native peoples:

The purpose behind the trust is and always has been to ensure the survival and welfare of Indian tribes and people. This includes an obligation to provide those services required to protect and enhance Indian lands, resources, and self-government, and also includes those economic and social programs that are necessary to raise the standard of living and social wellbeing of the Indian people to a level comparable to the non-Indian society. ${ }^{15^{\circ}}$

Although the federal trust responsibility is rooted in the U.S. government's obligation to compensate Native Americans, the unique government-to-government relationship that resulted has proven beneficial and detrimental. One benefit to tribes is the power to transact directly with the federal government and to receive federal funds without state involvement. However, some states have encroached on tribal sovereignty, primarily through attempts to limit tribal government jurisdiction and to tax and regulate tribal enterprise. A common misconception is that Native Americans do not pay taxes and thus should not benefit from state programs. While Native American lands are not taxed, Native

\footnotetext{
${ }^{11}$ William G. McLoughlin, "Cherokee Anomie, 1794-1810: New Roles for Red Men, Red Women, and Black Slaves," in American Encounters: Natives and Newcomers from European Contact to Indian Removal, 1500-1850, ed. Peter C. Mancall and James H. Merrell (NY: Routledge, 2000), p. 455; the Cherokee Nation, "A Brief History of the Cherokee Nation," 2002, <http://www.cherokee.org/Culture/HistoryPage.asp?ID=1>.

${ }^{12}$ Herndon and Sekatau, "The Right to a Name," pp. 427, 444; Narragansett Indian Tribe, "Narragansett Indian Tribe," $<$ http://www.narragansett-tribe.org $>$.

${ }^{13}$ For several examples of these obligations, see the Cherokee Nation, "Historical Facts," 2002, <http://www.cherokee. org/Culture/HistoryCat.asp?Cat=Facts $>$.

${ }^{14}$ U.S. General Accounting Office, "Economic Development: Federal Assistance Programs for American Indians and Alaska Natives," December 2001.

${ }^{15}$ American Indian Policy Review Commission, Final Report to Congress, vol. 1 (May 17, 1977), p. 130.
} 
Americans themselves pay considerable business, sales, and federal income taxes. ${ }^{16}$ Denial of services based on this premise ignores the true character of tribes' economic contributions to states. A study by the Arizona Commission of Indian Affairs found that for every dollar the state spent on a tribe, nearly $\$ 42$ was returned to the state through taxes assessed on businesses that operated on reservations and sales taxes that Native Americans paid on goods purchased off the reservation. ${ }^{17}$ Another study found that, in 1999, tribes contributed more than \$1 billion to Washington State's economy, much more than the state paid to provide services to Native Americans. ${ }^{18}$

Another misconception is that Native Americans do not need state assistance because they benefit from tax-free wealth generated by casino gaming. In reality, very few tribes have generated significant wealth from casino revenues; and casino income is taxed. Taxation and gaming are complex and outside the scope of this report, but it is important to note that the perception of casino-generated wealth is creating a new anti-Indian backlash and resistance to support funding for much-needed social services.

Federal programs that rely on block grants to states frequently underpay Native American recipients. Unless Native Americans are specifically designated as eligible recipients of funds, tribes often must negotiate with state governments to receive a share. Additionally, while eligible, Native Americans often do not have access to programs dedicated to specific needs, because of geographic isolation or the complexity of application processes. Furthermore, most federal programs are directed to Indian Country and not urban areas with significant Native populations. A combination of unequal access to programs and the wrong impression among the general population that Native Americans have an array of self-run programs that serve their needs has created large pockets of impoverished and underserved Native Americans in major cities and reservation border towns. ${ }^{19}$ All these factors complicate service delivery, making the receipt of services markedly more difficult for Native Americans than other populations.

\section{Trust Fulfillment as a Civil Right}

Before the passage of federal civil rights laws, Native Americans faced (as did African Americans and other groups) other, less subtle forms of legally sanctioned discrimination based on religion, culture, and race. In several states, for instance, not only did water fountains exist for "Whites" and "Coloreds," but also for "Indians." 20 Separation of the three groups, and the segregation of African Americans and Native Americans from whites, also occurred in public places such as movie theaters, which designated separate areas for "Colored" and "Indian." 21 Until 1954, one of the most common

\footnotetext{
${ }^{16}$ Stephen L. Pevar, The Rights of Indians and Tribes, The Authoritative ACLU Guide to Indian and Tribal Rights (Carbondale, IL: Southern Illinois University Press, 2002), p. 197 (hereafter cited as Pevar, The Rights of Indians and Tribes).

${ }^{17}$ Pevar, The Rights of Indians and Tribes, citing "Tribes Represent Multi-Million-Dollar Asset for Arizona," Indian Country Today, Feb. 4, 1993, p. A6.

${ }^{18}$ Pevar, The Rights of Indians and Tribes, citing "Washington Tribes Boost State Economy by \$1 Billion," Indian Country Today, Feb. 8, 1999, p. A6.

${ }^{19}$ Between 1953 and 1962, the height of the termination era, BIA's relocation program alone moved more than 160,000 Native Americans to cities. Later generations remain in urban areas. Kay Culbertson, president, National Council of Urban Indian Health, testimony before the Senate Committee on Indian Affairs, Washington, D.C., Feb. 26, 2003 , p. 4.

${ }^{20}$ U.S. Department of Justice, "American Indians," <http://www.usdoj.gov/kidspage/crt/indian.htm>.

${ }^{21}$ Hollywood's film version of the "Wild West," even in recent years presented a western frontier void of African Americans and populated by "dime store Indians" hindering the advancement of civilization by clinging to a "bygone" era and archaic beliefs. Of course, in many "Westerns" Native American characters were played by "Anglo" actors costumed to appear Native American, further adding to the distasteful representation.
} 
offenses in Arizona courts was "selling liquor to an Indian," a practice that was prohibited by Arizona's constitution. $^{22}$

Efforts to raise Native American living conditions to the standards enjoyed by other groups have only been in full motion since the 1960s, largely inspired by the drive of other disadvantaged groups. ${ }^{23}$ But the goals of Native Americans were, and are, somewhat distinct. While integration was a governmental objective for many antidiscrimination programs affecting blacks and Hispanics, this was not always the objective of government policy toward Native Americans. As noted above, in early years the federal government engaged in a policy of removal and segregation. In the era of termination (1946-1965), however, federal policy shifted toward one of forced acculturation, pushing thousands of Native Americans into urban areas, away from cultural and familial ties, and creating another form of isolation with brutal consequences. ${ }^{24}$

At the height of the civil rights movement, Native Americans resisted policies of forced integration and fought to preserve their unique cultural identities. Many Native Americans came to view civil rights as collective entitlements for which their ancestors bargained. ${ }^{25}$ It was around this time that the federal government recognized the need to establish a comprehensive Indian policy, which would acknowledge the hundreds of historical treaties, through legislation supporting Native American selfdetermination. The goal of self-determination maintains the federal protective role while increasing tribal participation in government. ${ }^{26}$ This goal has been eagerly embraced by Native Americans further asserting their rights and demanding redress for centuries of failed policies. Through their struggle, Indian tribes have retained most powers of government, such as public school administration, health care provision, and the administration of justice.

Today, Native Americans are subject to the same protections as other racial/ethnic and religious groups and are entitled to opportunities because of their unique status as (1) original inhabitants of U.S. land and (2) self-governing peoples. However, although current federal policies support selfdetermination, the lingering effects of past injustices remain. ${ }^{27}$ Attempts to self-govern and undo damages are undermined by the lack of resources and infrastructure necessary to adequately serve tribal members. At least in policy, the nation has clearly stated its promise to Native Americans. But laws and policies are meaningless without resources to enforce them. Resources are an important demonstration of the U.S. government's commitment to its responsibilities, including the obligation to preserve civil and other rights.

The federal government's failure to avail Native Americans of services and programs available to other Americans violates their civil rights. This report demonstrates that funding for services critical to Native Americans - including health care, law enforcement, and education - is disproportionately lower than funding for services to other populations. For example, the federal government's rate of spending on health care for Native Americans is 50 percent less than for prisoners or Medicaid re-

\footnotetext{
${ }^{22}$ Morris K. Udall, “The American Indians and Civil Rights,” Dec. 22, 1998, <http://www.library.arizona.edu/branches/ spc/udall/indian_htm.html>.

${ }^{23}$ Troy Johnson, “The American Indian Occupation of Alcatraz Island, 1969-1971," Introduction: Alcatraz, <http://www. csulb.edu/ gcampus/libarts/am-indian/alcatraz/001_001_intro_text.html>.

${ }^{24}$ U.S. Commission on Civil Rights, Indian Tribes: A Continuing Quest for Survival, June 1981, pp. 22-23 (hereafter cited as USCCR, A Continuing Quest for Survival).

${ }^{25}$ See Steve Russell, "Seeking Justice: Critical Perspectives of Native People: A Black and White Issue: The Invisibility of American Indians in Racial Policy Discourse," Georgetown Public Policy Review, vol. 4 (spring 1999), pp. 129-30.

${ }^{26}$ USCCR, A Continuing Quest for Survival, p. 23.

${ }^{27}$ Graham, "Indigenous Peoples," pp. 619, 625.
} 
cipients, and 60 percent less than is spent annually on health care for the average American. Underfunding violates the basic tenets of the trust relationship between the government and Native peoples and perpetuates a civil rights crisis in Indian Country.

For more than 40 years, the U.S. Commission on Civil Rights has documented the dismal conditions in Native communities. Sadly, conditions in Indian Country are current-day reflections of some of the Commission's earliest works, despite continued funding and promises to improve. To what degree the federal government has failed to live up to its obligations and the implications of that failure are questions to which the Commission now addresses itself. In every area reviewed-health, housing, law enforcement, education, food distribution - funding and services are inadequate, as they have been historically. Some observers have labeled the economic condition in Indian Country "termination by funding cuts, ${ }^{28}$ as funding has so severely limited the ability of tribal governments to provide the services needed to sustain life on reservations.

With this report, the Commission evaluates budgets and expenditures of the major federal agencies sponsoring Native American programs. The six agencies reviewed account for more than 90 percent of all federal spending on Native American programs. They are the Department of the Interior (DOI), the Department of Health and Human Services (HHS), the Department of Housing and Urban Development (HUD), the Department of Justice (DOJ), the Department of Education (DOEd), and the Department of Agriculture (USDA). ${ }^{29}$

\section{Methodology and Definitions}

The Commission obtained data independently and with the assistance of budget office personnel in the source agencies. The Commission analyzed agency budgets and, specifically, the budgets of offices that have financial assistance responsibilities for Native American nations. The Commission used a uniform interrogatory consisting of four questions and a uniform document request to obtain information from the agencies whose budgets are the subjects of this study. The project research team evaluated responses and conducted telephone inquiries to obtain clarification and additional information. The Commission also conducted a literature review and analyzed documents pertinent to the topic.

The analysis focused on the funding amounts for Native American programs between fiscal years 1998 and 2003, as well as requests for 2004. Unless otherwise indicated, all references are for fiscal and not calendar years. The federal fiscal year runs from October 1 through September 30, beginning the previous calendar year. For example, fiscal year 2003 is October 1, 2002, through September 30, 2003.

Specific focus was given to the adequacy of funding and whether it has kept pace with inflation. All references to real funding are expressed in constant 2003 dollars. Expression in constant (present value) dollars accounts for inflationary trends and more accurately reflects the actual purchasing power of the funds. In previous Commission reports, as well as this one, inflation-adjusted values are referred to as "real funding" or "real spending power." Furthermore, "current" or "actual" dollars are exact dollar amounts appropriated in the year discussed. "Constant" or "adjusted" dollars are the dol-

\footnotetext{
${ }^{28}$ Nancy Thorington, "Civil and Criminal Jurisdiction Over Matters Arising in Indian Country: A Roadmap for Improving Interaction Among Tribal, State and Federal Governments," McGeorge Law Review, vol. 31 (summer 2000), pp. 986-87.

${ }^{29}$ Other agencies that fund Native American programs include the Departments of Commerce, Defense, Labor, Veterans Affairs, Transportation, and the Treasury, as well as the Environmental Protection Agency and the Small Business Administration.
} 
lar values after accounting for inflation. To make the adjustment, the Commission used the same deflators as those used by the Office of Management and Budget (OMB) in the Budget of the United States: Historical Tables, Fiscal Year 2004 (table 1.3, p. 26). The deflators have been used in other analyses performed by the Commission, and thus assist reader efforts to make parallel comparisons.

To facilitate comparison across agencies, this report uses actual budget authority as the definitive amount of funding, unless otherwise noted. Budget authority is the amount that Congress determines an agency is allowed to spend for a given fiscal year. OMB defines budget authority as, "the authority provided in law to enter into legal obligations that will result in immediate or future outlays of Government funds." 30 This report also uses the term "program level" when it refers to an agency's budget authority and its receivables, such as payment for products, services, and interest. The term "requested appropriations" generally refers to the amount of funding proposed by the President based on an agency's past spending, its future estimates, and expressed priorities.

A department's budget is generally composed of two types of funds: mandatory (or direct) and discretionary. Discretionary authority is only provided in an annual one-time appropriations act; mandatory authority is authorized through legislation (i.e., required by law). ${ }^{31}$ In most instances, Native American programs receive discretionary funding. ${ }^{32}$ The budget authority expressed in an agency's budget depends on whether the law specifies an exact amount (definite authority) or specifies a variable factor that determines the amount (indefinite authority). Current funding is the amount that can be spent in the current year, and permanent funding is the amount of money always available for a particular purpose. ${ }^{33}$

The term "set-aside" is used by federal agencies and in this report to identify funds allocated to Native American programs from funding for programs available to all populations. ${ }^{34}$ For example, a program open to all U.S. citizens is funded at $\$ 100$ million for fiscal year 2003; from the $\$ 100$ million the amount of $\$ 5$ million or 5 percent might be specifically targeted or set aside for Native American individuals, governments, or organizations.

\section{The Native American Population}

Compared with other racial and ethnic groups in the United States, Native Americans make up a relatively small proportion of the population. Often considered the "invisible minority," their numbers are relatively small and percentages too minute to register on established government-reported tracking scales. In addition, their geographic location leaves those who reside, attend school, or work on reservations isolated from the rest of society. The tendency of American society to respond foremost to visible problems results in Native Americans being overlooked and, in the minds of many, forgotten. However, there are nearly 2.5 million individuals in the United States who identify themselves as American Indian or Alaska Native (0.9 percent of the population); another 1.6 million identify as part

\footnotetext{
${ }^{30}$ Office of Management and Budget, Budget of the United States Government, Fiscal Year 2004, Analytical Perspectives, p. 466 (hereafter cited as OMB, FY 2004 Budget, Analytical Perspectives).

${ }^{31}$ OMB, FY 2004 Budget, Analytical Perspectives, p. 468.

${ }^{32}$ A notable exception is the Food and Nutrition Service of the Department of Agriculture, which also receives mandatory funding.

${ }^{33}$ OMB, FY 2004 Budget, Analytical Perspectives, p. 468.

${ }^{34}$ See Christopher D. Boesen, executive director, National American Indian Housing Council, testimony before the Senate Committee on Indian Affairs, Feb. 23, 2000, for examples of Native American funding set-asides.
} 
American Indian or Alaska Native. ${ }^{35}$ (Note that the 2000 census was the first time individuals were allowed to identify as more than one race; therefore, caution should be used when making comparisons with previous census counts. Where possible, this analysis focuses on those who identified as American Indian/Alaska Native alone.) The Native American population is growing at a faster rate than the U.S. population in its entirety. There was a 26 percent increase in the American Indian/Alaska Native alone category and a 110 percent increase among all Native Americans (alone and in combination with another race) between the 1990 and 2000 censuses. During that same time, the U.S. population increased 13 percent. $^{36}$

Native Americans are more geographically clustered than other populations, with 62 percent residing in 11 states. More Native Americans live in the West than any of the other three regions of the country (48 percent). ${ }^{37}$ Among all Native Americans, 79.3 percent report being enrolled in or affiliated with a tribe (compared with 66.9 percent of those reporting themselves as Native American and another race). There are currently 562 federally recognized Native American tribes in the United States. The tribes with the largest membership or affiliation are the Cherokee, Navajo, Choctaw, Sioux, Chippewa, and those identified as Latin American Indian. ${ }^{38}$ These six groups account for 40 percent of all Native Americans. Eskimo is the largest group among Native Alaskans, followed by TlingitHaida, Alaska Athabascan, and Aleut; these four groups combined make up only 3.6 percent of all Native Americans who reported tribal affiliation. According to the 2000 census, nearly 60 percent of Native Americans live in urban areas, compared with roughly 38 percent in $1990{ }^{39}$ The remaining 40 percent live on reservations, trust lands, or bordering rural areas. ${ }^{40}$

The socioeconomic condition of the Native American population in the United States reveals a dire need for increased national attention. Native Americans rank at or near the bottom of nearly every social, health, and economic indicator. For example, the national poverty rate in the Unites States for the period between 1999 and 2001 was 11.6 percent. For Native Americans nationally, the average annual poverty rate was 24.5 percent. That is, nearly a quarter of Native Americans - more than twice the national average-live in poverty. ${ }^{41}$ Nearly one in three (31.2 percent) of those residing on reservations live in poverty. The unemployment rate in the Native American population nationwide is 12.4 percent, more than twice the general unemployment rate. ${ }^{42}$ On reservations, unemployment averages 13.6 percent, but varies widely across the nation. Unemployment among the Navajo, for example, is 25 percent; on the Pine Ridge and Rosebud reservations in South Dakota, unemployment

\footnotetext{
${ }^{35}$ U.S. Census Bureau, “The American Indian and Alaska Native Population: 2000," February 2002 (hereafter cited as Census Bureau, “AI/AN Population: 2000”).

${ }^{36}$ Census Bureau, “AI/AN Population: 2000,” p. 3.

${ }^{37}$ Ibid., p. 4. The states with the largest Native American populations, in descending order, are California, Oklahoma, Arizona, Texas, New Mexico, New York, Washington, North Carolina, Michigan, Alaska, and Florida. California and Oklahoma combined account for 25 percent of the total Native American population. The census identifies the four geographical regions as Northeast, Midwest, South, and West. Ibid.

${ }^{38}$ In 1997, the Office of Management and Budget definition of American Indian or Alaska Native included the original peoples of North and South America, including Central America. Census Bureau, "AI/AN Population: 2000, , p. 8.

${ }^{39}$ U.S. Department of Health and Human Services, Indian Health Service, FY 2004 Budget Request, Justification of Estimates for Appropriations Committees, <http://www.ihs.gov/AdminMngrResources/Budget/FY_2004_Budget_Justification.asp>, p. 93.

${ }^{40}$ Senators Campbell and Inouye, letter to the Senate Committee on the Budget, Mar. 1, 2002, p. 120.

${ }^{41}$ U.S. Census Bureau, "Poverty in the United States: 2001," Current Population Reports, September 2002, p. 7.

${ }^{42}$ U.S. Census Bureau, "Sex by Employment Status for the Population 16 Years and Over (American Indian and Alaska Native Alone)," detailed table, <http://www.factfinder.census.gov/servlet/DTTable?ts=75210518085>.
} 
exceeds 33 percent; and on the Kickapoo reservation in Texas, unemployment is nearly 70 percent. ${ }^{43}$ Of Native Americans aged 18 to 24, only 63.2 percent have graduated from high school (compared with 76.5 percent of the United States population) and of those 25 years and older, only 9.4 percent have completed four or more years of college (compared with 20.3 percent nationally). ${ }^{44}$

As subsequent chapters will demonstrate, the poor socioeconomic status of Native Americans resonates through myriad aspects of social and fiduciary policy from education to health care to housing. Stunted economic development in Native communities calls for increased national commitment that preserves the right to self-governance and self-determination. History has shown that self-governance and self-determination, in spite of promises, have come at the cost of constant struggle.

\section{Unmet Needs, Fiscal Years 1998-2003}

This study analyzes federal funding for Native American programs and services from 1998 through 2003, as well as estimated funding for 2004, where available. ${ }^{45}$ The report focuses on the adequacy of federal funding for programs and services targeting "American Indians, Federally Recognized Indian Tribal Governments and Native American Organizations." 46 Attention is directed at unmet needs, the portion of basic needs among Native Americans that the government is supposed to supply but does not. Basic needs encompass such critical items as health (e.g., medical facilities, clean drinking water); education (e.g., books, structurally sound school buildings); law enforcement (e.g., a sufficient number of law enforcement personnel); and housing (e.g., indoor plumbing, a sufficient number of houses).

In a statement to Congress in 1999, some Native American leaders estimated their collective unmet needs at more than $\$ 899$ million. ${ }^{47}$ By 2001, the government's own nationwide estimate of unmet needs for Native American school facilities alone reached $\$ 1$ billion; ${ }^{48}$ it was estimated that another $\$ 1.8$ billion was needed to achieve health care parity. ${ }^{49}$ According to the chair and vice chair of the Senate Indian Affairs Committee, the President's 2003 budget request for Indian programs did not provide "the resources necessary to effectively address or remedy the longstanding problems in Indian Country." 50

\footnotetext{
${ }^{43}$ U.S. Census Bureau, "Employment Status and Commuting to Work: 2000," summary file, <http://www.factfinder. census.gov/servlet/GCT Table?_ts $=75215796856>$.

${ }^{44}$ U.S. Census Bureau, "Selected Social and Economic Characteristics for the 25 Largest American Indian Tribes," August 1995.

${ }^{45}$ Every effort has been made to obtain funding amounts (also known as outlays or appropriations) provided to Native Americans/Alaska Natives whenever these figures were available. Actual funding is here defined as the amount of money provided by federal agencies, as appropriated by Congress, for Native American/Alaska Native programs versus, for example, the amount requested.

${ }^{46}$ The terms "American Indians," "Federally Recognized Indian Tribal Governments," and "Native American Organizations" are borrowed from the Catalog of Federal Domestic Assistance and include Alaska Native groups, <http://www.cfda.gov>.

${ }^{47}$ Kevin Gover, assistant secretary for Indian affairs, U.S. Department of the Interior, testimony before the Senate Committee on Indian Affairs, Feb. 24, 1999.

${ }^{48}$ Senators Campbell and Inouye, letter to the Senate Committee on the Budget, Mar. 1, 2002, p. 121.

${ }^{49}$ See chapter 3.

${ }^{50}$ Senators Campbell and Inouye, letter to the Senate Committee on the Budget, Mar. 1, 2002, p. 121.
} 


\section{Federal Funding of Native American Programs}

In 1993, budget authority for Native American programs across all federal agencies was roughly \$5.6 billion. By 1999, budget authority had grown to $\$ 7.8$ billion. By 2003, the budget estimate for these programs was $\$ 10.6$ billion. ${ }^{51}$ Although in actual dollars funding increased roughly 89 percent, after adjusting for inflation, the increase is actually closer to 55 percent. During the same period, the entire federal budget authority increased from roughly $\$ 1.47$ trillion in 1993 to $\$ 2.16$ trillion in 2003, a 46.7 percent growth. ${ }^{52}$ The same growth was evident in governmentwide discretionary funding. Although Native American programs have grown at a faster rate than total government spending, such programs constituted only 0.4 percent of total government spending in 1993 and 0.5 percent in 2003, not a significant increase by federal budget standards. Furthermore, this formula fails to take into consideration market-specific inflation, such as increasing health care and housing costs, that weakens the strength of the dollar over time.

FIGURE 1.1

Actual and Constant Governmentwide Spending on Native American Programs, FY 1993-2003

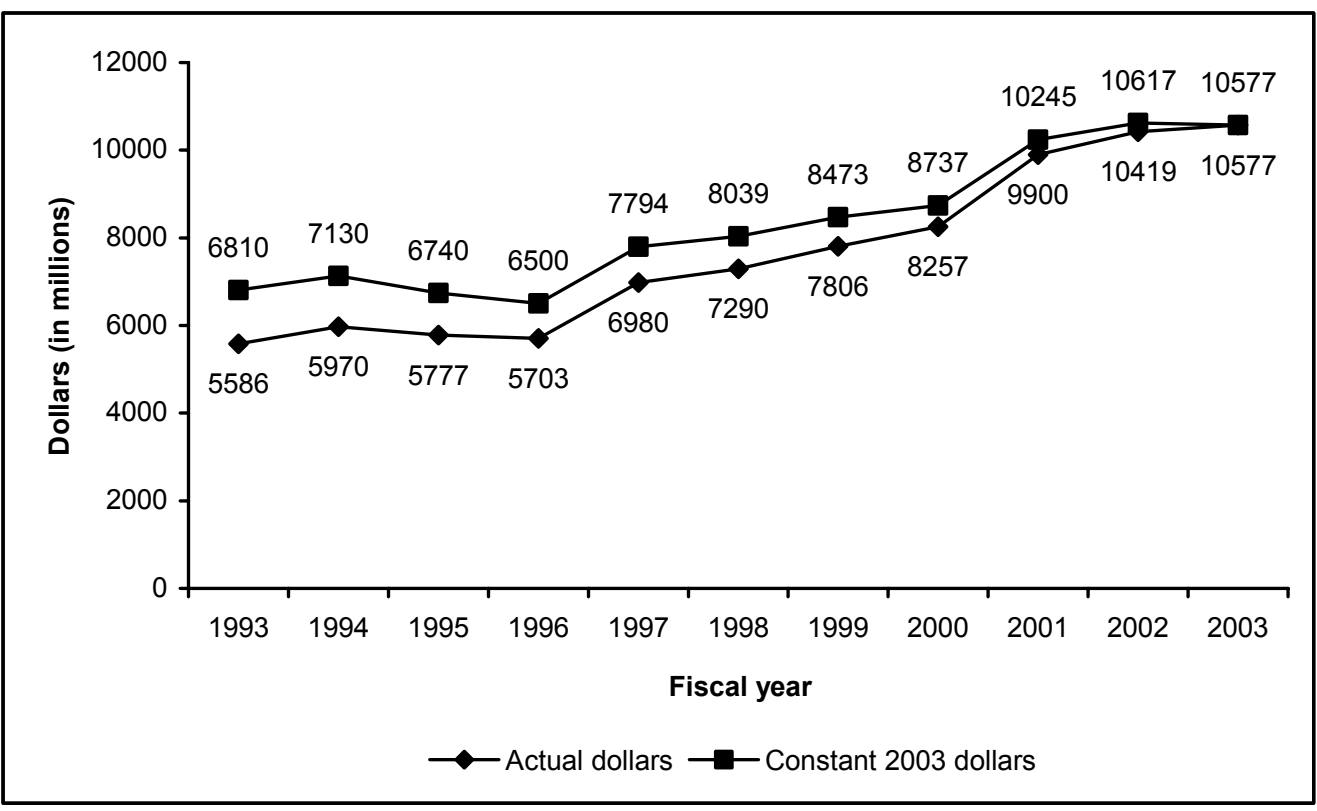

Sources: Department of the Interior and Related Agencies Appropriations Bills: H.R. REP. No. 102-116 (1991); H.R. Rep. No. $103-158$ (1993); H.R. Rep. No. 103-551 (1994); H.R. ReP. No. 104-173 (1995); H.R. ReP. No. $104-625$ (1996); H.R. REP. No. 105-163 (1997); H.R. REP. No. 105-609 (1998); H.R. REP. No. 106-222 (1999); H.R. REP. No. 106-646 (2000); and H.R. REP. No. 107-564 (2002).

According to members of the Senate Indian Affairs Committee, despite a marked increase in governmentwide funding beginning in 1993, a decline in spending power has been evident for decades. ${ }^{53}$ As figure 1.2 illustrates, per capita federal spending on Native Americans was higher than spending

\footnotetext{
${ }^{51}$ Department of the Interior and Related Agencies Appropriations Bills: H.R. REP. No. 103-551 (1994); H.R. REP. NO. 106-646 (2000); and H.R. REP. NO. 107-564 (2002).

${ }^{52}$ Office of Management and Budget, Budget of the United States Government, Fiscal Year 2003, table 5.2, pp. 95-96.

53 "Statement of Chairman Ben Nighthorse Campbell, Committee on Indian Affairs, on the Budget Request for the BIA and HHS," Feb. 26, 1997, <http://indian.senate.gov/hearings/226_bnc.html>; Senators Campbell and Inouye, letter to the Senate Committee on the Budget, Feb. 29, 2000, pp. 186-89.
} 
for the general population between 1975 and 1980. Between 1980 and 1985, however, Native American expenditures declined while those for the general population increased, until approximate equivalency. After 1985, per capita Native American and general population spending did not increase at the same rates, resulting in a wide gap. The Native American population has grown at a faster rate than the U.S. population as a whole; therefore, overall spending increases have not translated to equivalent per capita spending increases. ${ }^{54}$

FIGURE 1.2

Per Capita Government Expenditures, U.S. Population vs. Native American Population, 1975-2000, in Current Dollars

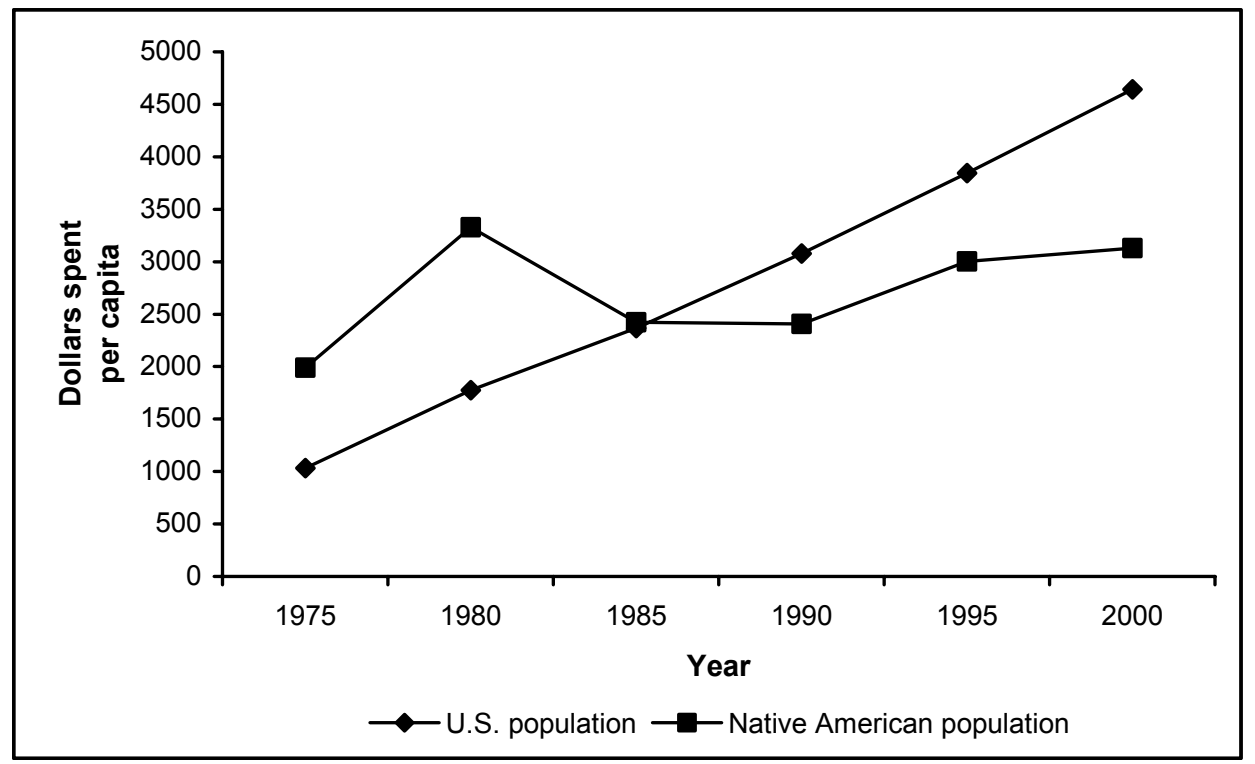

Note: Data used for this analysis compare funding for major Indian-related programs and federal nondefense funding.

Source: Roger Walke, specialist in American Indian policy, Domestic Social Policy Division, Congressional Research Service, memorandum to the Senate Committee on Indian Affairs, re: Indian-Related Federa Spending Trends, 1975-2001, Mar. 1, 2000, appendix, table 1.

Federal agencies providing the largest amount of financial assistance to Native Americans (DOI, HHS, HUD, DOJ, DOEd, and USDA) show the same trend. Funding for Native American programs in fiscal year 2003 for the six agencies studied here is roughly \$2.1 billion more than fiscal year 1998 appropriations; after adjusting for inflation, the increase is actually closer to $\$ 1.6$ billion. While this appears encouraging, within some specific programs funding has been flat or declining for years, and other programs have gone unfunded. Making matters worse, Native American population needs have increased at a rate faster than inflation, as problems are compounded by years of neglect. Thus, the purchasing power of Native American assistance programs has generally not been sufficient and, in some cases, has been reduced dramatically. Already substandard housing conditions have deteriorated further, and health problems that could easily be remedied persist. This report expresses the difference between the needs of Native peoples and the funding of those needs by the six federal agencies. By assessing needs against funding, this report finds evidence of a quiet crisis; specifically that

\footnotetext{
${ }^{54}$ Roger Walke, specialist in American Indian policy, Domestic Social Policy Division, Congressional Research Service, memorandum to the Senate Committee on Indian Affairs, re: Indian-Related Federal Spending Trends, 1975-2001, Mar. 1, 2000, pp. 9-10.
} 
federal funding for Native American programs is inadequate and goes unnoticed because it is unreported, unmonitored, unaccounted for, and inconsistently tracked.

Individual agencies are expected to report to the Office of Management and Budget the amount spent on Native American programs annually. Yet, there are no apparent guidelines for how that information should be reported, or for what must be included. Some agencies report direct and indirect funding; others estimate how many Native Americans benefit from programs that serve the general public, not just those directed specifically to tribes, villages, and Native American individuals. Any exercise involving the collection of budget data for federal Native American programs is thus difficult and likely compromised by the lack of uniformity in reporting.

\section{Department of the Interior}

The Department of the Interior (DOI), through its Bureau of Indian Affairs (BIA), is the federal agency that works most closely with Native American individuals, governments, and organizations. ${ }^{55}$ DOI and BIA are responsible for addressing a wide range of Native American needs (including economic development, public safety, and education) through numerous federal programs operated by BIA. Between 1998 and 2003, DOI and BIA provided an average of \$2 billion per year in funding for programs targeting Native Americans. In several instances, funds for BIA-managed Native American programs were transferred to BIA from other federal agencies. BIA education programs, for example, are partially operated by funds transferred from the Department of Education in conjunction with funds supplied by BIA. ${ }^{56}$

During the period from 1998 through 2004, the percentage of the total DOI budget directed toward BIA has fluctuated, declining between 2000 and 2002. Over this period, BIA's funding of tribal priority allocations (grants to Native American governments for such basic services as child welfare), for example, also declined from 42 percent of BIA's budget in 1998 to 35 percent in 2002, and may only be 33.3 percent of the budget in 2004 .

\section{Department of Health and Human Services}

The Department of Health and Human Services (HHS) receives the largest budget appropriation of all federal agencies for Native American-specific programs. ${ }^{57}$ The agency's allocation was slightly more than $\$ 4$ billion for health and related services to Native Americans in 2003. The Indian Health Service (IHS) itself has a budget authority of \$2.6 billion. Between 1998 and 2003, the department's overall appropriation for Native programs steadily increased about 33 percent, in constant dollars; the increase for IHS was approximately 35 percent. However, Native American health programs remain a low budget priority, as IHS constitutes only 0.5 percent of the total HHS budget and only 4.4 percent of the department's entire discretionary budget, the subset of the total budget from which Native American programs are funded.

IHS has many significant responsibilities, including clinical care, preventive health care, facility construction and maintenance, health professional development, and community sanitation improvement. Yet, as this analysis will demonstrate, the agency is so fiscally constricted that it cannot pro-

\footnotetext{
${ }^{55}$ See chapter 2 for a discussion on DOI programs.

${ }^{56}$ See chapter 6 for a discussion on DOEd funds transferred to BIA.

${ }^{57}$ See chapter 3 for a discussion on HHS programs.
} 
vide basic health services to its user population, much less address the specific and critical health needs of Native communities. Native Americans receive less funding per capita than any other group for which the federal government has health care responsibilities, including Medicaid/Medicare recipients, veterans, and prisoners. The legal and moral obligation to provide health care to Native Americans has not been met, and unless IHS receives an exponential increase in funding, health conditions are not likely to improve and will likely worsen.

\section{Department of Housing and Urban Development}

The Department of Housing and Urban Development (HUD) is charged with housing construction and maintenance on Native American trust lands and reservations. ${ }^{58}$ Under the Native American Housing Assistance and Self-Determination Act (NAHASDA) of 1996, the federal government makes block grants to tribes and tribally designated housing entities. ${ }^{59}$ While the block grant program has led to greater local control, its success has been undercut by lack of funding. At its current level, NAHASDA funding will only meet 5 percent of the total need for housing in Native communities.

Between 1998 and 2003, Native American housing program funding remained relatively stable. While HUD's overall budget authority increased 62 percent, Native American funding only increased 8.8 percent. When accounting for inflation, this amounts to an actual decrease in spending power. Native American program funding makes up a smaller proportion of HUD's discretionary budget today than it did five years ago. HUD also guarantees home mortgages for individuals who cannot obtain financing from private lenders. During the period under review, funds for these programs dwindled as well, reducing the amount of loans supported and lessening the opportunity for homeownership. Given the unique housing challenges Native Americans face-including impoverished economic conditions, restrictions on individual land rights, lack of homeownership, and substandard housing - greater and immediate federal financial support is imperative.

\section{Department of Justice}

The Department of Justice (DOJ) plays a significant role in law enforcement and public safety on reservations and Indian trust lands, working in collaboration with the Bureau of Indian Affairs and tribal judicial systems. ${ }^{60}$ DOJ has made efforts in recent years to curb the growing crime and victimization rates in Native communities, mainly through grant programs and technical assistance. Many of the department's Native programs are disbursed through the Office of Justice Programs (OJP). In addition, the agency has established an Office of Tribal Justice to coordinate efforts within the agency and foster communication with tribes.

DOJ has initiated many badly needed programs, several of which remain underfunded or completely without funding. Between 1998 and 2003, the department's budget authority increased 23.3 percent and its discretionary budget increased 5.4 percent. During that same period, its funding for Native American programs increased 86.7 percent. Despite this increase, however, funding for Native American programs remained roughly 1 percent of the agency's total budget. This can be explained by the fact that the budget for Indian programs is so small to begin with that even substantial in-

\footnotetext{
${ }^{58}$ See chapter 4 for a discussion on HUD programs.

${ }^{59}$ Native American Housing Assistance and Self-Determination Act of 1996, Pub. L. No. 104-330, 110 Stat. 4016 (codified as amended at 25 U.S.C. $\S \S 4101-4212$ (Supp. IV 1998)).

${ }^{60}$ See chapter 5 for a discussion on DOJ programs.
} 
creases have not changed its proportion to the overall budget. OJP funding for Native American programs more than doubled between 1998 and 1999, but it too has not changed proportionate to OJP's entire budget authority.

As a result of the agency's deficient funding, many unmet law enforcement needs persist in Indian Country. Among the most severe are basic police services, tribal court systems, and adequate correctional facilities. The agency has engaged in collaborative efforts to remedy these problems, but funding has not been enough to establish justice systems that will eventually be self-sufficient.

\section{Department of Education}

The Department of Education (DOEd) funds the education of Native American students by (1) operating Native American-targeted programs, (2) setting aside funds within programs open to all students, and (3) transferring funds to BIA for BIA-managed schools. ${ }^{61}$ Between 1998 and 2001, the Office of Indian Education's (OIE) budget steadily increased until it reached 0.3 percent or $\$ 115.5$ million of DOEd's $\$ 40.1$ billion discretionary budget. Commencing in 2002, and carrying through the 2004 budget estimate, OIE's share of this budget has declined $(0.2$ percent or $\$ 120.4$ million in 2002 and 0.2 percent or $\$ 121.6$ million in 2003) and may again only be 0.2 percent or $\$ 122.4$ million in 2004 (based on a proposed DOEd discretionary budget authority of $\$ 53.1$ billion).

Between 1998 and 2003, funding was completely absent for numerous subprograms. Native American self-determination is hindered, if not imperiled, by the federal government's failure throughout this period to appropriately fund programs whose necessity has been established by law. DOEd Native American programs are often funded at the minimum level established by Congress, never the maximum. The federal government has not upheld its legal and moral obligation to provide sufficient funding for the education of Native American students.

\section{Department of Agriculture}

The Department of Agriculture (USDA) provides financial assistance to Native Americans via an assortment of programs and services, covering such areas as economic development and nutritional assistance. ${ }^{62}$ From 1999 through 2003, USDA provided an average of $\$ 139.3$ million each year in funding for programs targeting Native Americans. Compared with other federal agencies, this is a small amount, yet USDA's programs are crucial.

Among these programs is the Rural Community Advancement Program, which is designed to alleviate the perpetual state of poverty in several rural communities throughout the United States, including Native American reservations. Program funding for Native Americans is established by a setaside in the program's total budget. Although the percentage set aside for Native Americans rose between 2000 and 2001, a declining program budget may provide Native Americans only \$13 million in 2004 compared with $\$ 15.9$ million in 2003 and $\$ 19.9$ million in 2002 . If the 2004 budget is approved, it will mean a decrease of $\$ 2.9$ million or 18.2 percent from 2003 .

The Food Distribution Program on Indian Reservations (FDPIR), an alternative to the Food Stamp Program, which provides Native Americans with a nutritional source when no other may be available, has also had its purchasing power diminish. Between 1999 and 2003, FDPIR experienced a de-

${ }^{61}$ See chapter 6 for a discussion on DOEd programs.

${ }^{62}$ See chapter 7 for a discussion on USDA programs. 
crease of $\$ 2.2$ million or 2.8 percent after adjusting for inflation. Although this would be a critical issue for any group, it is especially severe for Native Americans because they are twice as likely to suffer from food insecurity and hunger than the general population. In fact, USDA found that from 1995 to 1997, 22.2 percent of Native American households where unsure about the likelihood of their next meal. Moreover, during this period, one or more members of these households suffered from moderate to severe hunger, with 8.6 percent experiencing both food insecurity and hunger. Clearly, USDA must ensure that adequate funds are available for such imperative Native American programs, which account for the difference between health and illness, for communities struggling to escape poverty and despair.

\section{Conclusion}

Federal agencies bear enormous responsibility for enforcing the laws that protect Native Americans from further civil rights denials. An array of agencies use various means to carry out their responsibilities. Among their duties are investigation of discrimination complaints, administration of grant programs, negotiation of agreements, and initiation of legal proceedings. The government has designated agencies to coordinate Native American programs of one type in an effort to eliminate duplication and foster consistency. However, efforts are not always coordinated efficiently and, as will be demonstrated, there is little consistency across agencies for reporting needs, tracking resources, and determining outcomes.

This report readily demonstrates the effects of rising costs on how much travel, equipment, supplies, or services an agency can purchase. Policymakers must bear in mind other more nuanced consequences of deficient funding. For example, decreased funding is often associated with reduced staffing, a decision that may limit coordination activities. Wasteful duplication and inconsistencies that result can drain scarce resources and unduly burden those individuals programs are intended to help. Resource scarcity may also limit the amount of training, technical assistance, public education, and outreach an agency can provide. Moreover, perennial shortfalls retard progress and reverse gains made during stronger funding cycles. The implications for federal policy, government agencies, and most importantly Native Americans render the need to act upon this report even more urgent. 


\section{Chapter 2: Department of the Interior}

President Bush and I are both believers in the concept of Indian Self-Determination. We want to make advances in Self-Determination and Self-Governance during our tenure which we believe can be fostered through consultation and our mutual goal of better government. ${ }^{1}$

On February 3, President Bush proposed a \$2.29 trillion budget for FY 2004 that included largely level funding for Indian programs, continuing the trend of consistent declines in federal per capita spending for Indians compared to per capita expenditures for the population at large. This trend demonstrates the abject failure of the federal government to commit the serious resources needed to fully honor its trust commitment to Indian tribes. ${ }^{2}$

The U.S. Department of the Interior (DOI) is the federal agency working most intimately with Native American individuals, governments, and organizations. ${ }^{3}$ Through its Bureau of Indian Affairs (BIA), DOI addresses such Native American needs as economic development, protection of land and water rights, development of forestlands, leasing of assets on Native American lands, and the development and maintenance of infrastructure. ${ }^{4}$ In fact, within DOI, and the federal government as a whole, BIA is assigned the primary responsibility for providing federal services to the 562 federally recognized Native American tribes. ${ }^{5}$

Directing BIA is the assistant secretary for Indian affairs, a position created in 1977. Since its inception, there have been nine assistant secretaries, including the current acting assistant secretary. ${ }^{6}$ The assistant secretary, as BIA's designated leader, is charged with ensuring that BIA provides Native Americans with adequate and efficient federal services. Specifically, DOI tasks the assistant secretary with discharging the department's trust responsibilities and promoting self-determination among Native Americans. ${ }^{7}$ Because BIA has not always managed to adequately provide these services, the

\footnotetext{
${ }^{1}$ Gale Norton, Secretary of the Interior, testimony before the Senate Committee on Indian Affairs, Washington, D.C., Feb. 28, 2001 (hereafter cited as Norton testimony).

${ }^{2}$ Tex Hall, president, National Congress of American Indians, testimony before the Senate Committee on Indian Affairs, Washington, D.C., Feb. 26, 2003 (hereafter cited as Hall testimony).

${ }^{3}$ U.S. Congress, Senate Committee on Indian Affairs, Oversight Hearing before the Senate Committee on Indian Affairs to Receive the Views of the Department of the Interior on Matters of Indian Affairs, Feb. 28, 2001.

${ }^{4}$ U.S. Department of the Interior, "Bureau of Indian Affairs, Mission Statement," Orientation to the U.S. Department of Interior, <http://www.doiu.nbc.gov/orientation/bia2.cfm> (hereafter cited as DOI, "BIA Mission Statement").

${ }^{5}$ U.S. Department of the Interior, "News, U.S. Department of Interior, Office of the Assistant Secretary-Indian Affairs, Secretary Norton Names Aurene M. Martin Acting Assistant Secretary-Indian Affairs," Jan. 6, 2003 (hereafter cited as DOI, "News DOI," Jan. 6, 2003).

${ }^{6}$ DOI, "News DOI," Jan. 6, 2003; U.S. Department of the Interior, "News, U.S. Department of Interior, Office of the Assistant Secretary-Indian Affairs, Martin Confirms Terry Virden as BIA Deputy Commissioner,” Feb. 10, 2003; DOI, "BIA Mission Statement."

${ }^{7}$ DOI, “News DOI,” Jan. 6, 2003.
} 
acting assistant secretary has been assigned the task of making BIA "an efficient and effective Indian service." $"$

DOI's failure to provide Native Americans with efficient and effective services is perhaps best exemplified in relation to the issue of "trust." In this context, trust refers to the government-togovernment relationship between Native Americans, as sovereign political bodies, and the United States government. ${ }^{9}$ Trust, in this general sense, is defined by three components: land, selfgovernance, and social services, which together require that the federal government compensate Native Americans for what they surrendered to the United States - most notably their land. ${ }^{10}$ Examined within the context of compensation, DOI and BIA have failed Native Americans through the mismanagement of Native American fiscal resources, or Individual Indian Money (IIM) trust accounts, in which the United States acts as trustee of accounts holding income from land leases on behalf of individual Native American beneficiaries. ${ }^{11}$

According to a 2001 U.S. General Accounting Office (GAO) report, DOI was unable to assure trust account holders that their balances were accurate or that their assets were being properly managed. GAO asked DOI to update its trust fund management information systems to ensure the accuracy of its records. In order to achieve accuracy, DOI had to correct thousands of inaccurate, incomplete, or outdated entries. ${ }^{12}$ Despite taking actions to address management problems, in 2003 GAO reported that additional weaknesses, including inadequate accounting and information systems and internal controls, still prevented DOI from ensuring the proper management of funds. ${ }^{13}$

Five years before GAO's 2001 report, a class action lawsuit was filed against DOI and the U.S. Department of the Treasury concerning IIM trust accounts. ${ }^{14}$ The suit accused the government of mismanaging the accounts by losing, destroying, or not reporting them. ${ }^{15}$ According to the plaintiffs, the federal government owes concerned parties \$137 billion in restitution for failing to provide full roy-

\footnotetext{
${ }^{8}$ National Academy of Public Administration, “A Study of Management and Administration: The Bureau of Indian Affairs," Resources, Congressional Testimony, Mar. 8, 2000, < http://www.napawash.org/resources/testimony/testimony_ 03_08_00.htm>; DOI, "News DOI," Jan. 6, 2003.

${ }^{9}$ See Senator Ben Nighthorse Campbell, chair, and Senator Daniel K. Inouye, vice chair, Senate Committee on Indian Affairs, letter to the Senate Committee on the Budget, Mar. 1, 2002, as reported in Concurrent Resolution on the Budget, FY 2003, Report of the Committee on the Budget, United States Senate, Apr. 11, 2002, p. 121 (hereafter cited as Senators Campbell and Inouye, letter to the Senate Committee on the Budget, Mar. 1, 2002); Hall testimony.

${ }^{10}$ American Indian Policy Review Commission, Final Report to Congress, vol. 1 (May 17, 1977), p. 130. See chapter 1.

${ }^{11}$ Mismanagement of the IIM trust accounts is the subject of ongoing litigation. See Cobell v. Babbitt, 30 F. Supp. 2 d 24, 27 (D.D.C 1998); Gerald Murphy, fiscal assistant secretary, U.S. Department of the Treasury, "Interpretation Number 1, Reporting on Indian Trust Funds in General Purpose Financial Reports of the Department of the Interior and in the Consolidated Financial Statements of the United States Government: An Interpretation of SFFAS 7," <http://www.fasab.gov/intprt1.htm>. Currently, the Indian trust funds are managed by Interior's Office of the Special Trustee, Office of the Secretary. Prior to 1996, BIA managed the trust fund. The leasing of Native American land is a complex issue and beyond the scope of the current analysis.

${ }^{12}$ U.S. General Accounting Office, Performance and Accountability Series: Major Management Challenges and Program Risks, January 2001, pp. 8-9.

${ }^{13}$ U.S. General Accounting Office, Performance and Accountability Series: Major Management Challenges and Program Risks, January 2003, p. 14.

${ }^{14}$ Cobell v. Babbitt, 30 F. Supp.; J. Michael Kennedy, “Truth and Consequences on the Reservation," Los Angeles Times Magazine, July 7, 2002, p. 14.

${ }^{15}$ Cobell v. Babbitt, 30 F. Supp. 2d 24, 29; Dean Schabner, "\$137 Billion Missing: Government Continues to Lie About Reform of Trust Accounts, Judge Says," ABCNews.com, September 2002 (hereafter cited as Schabner, "\$137 Billion Missing").
} 
alties on leases covering 90 million acres of land for a century. ${ }^{16}$ Furthermore, the plaintiffs allege that the defendants are charged with the duties of trustee with regard to the IIM accounts, including maintaining an adequate accounting and records system, investing the funds in the accounts prudently, reporting to beneficiaries, and refraining from self-dealing. ${ }^{17}$

The federal judge presiding over the case decided that DOI did very little and lied about it in order to cover up its continued failure, despite having been ordered to initiate steps to correct account problems. Specifically, the judge stated that DOI either refused or was unable to properly manage the trust account. ${ }^{18}$ The judge viewed the situation so gravely that he held the Secretary of the Interior and the assistant secretary for Indian affairs in contempt of court on the counts of:

- committing fraud on the court by concealing the true actions of the department regarding the historical accounting;

- committing fraud on the court for misrepresentations regarding Internet technology security failures at the department;

- committing fraud on the court for failing to disclose the true status of the Trust Assets Accounting Management System project; and

- committing fraud on the court by filing false and misleading status reports regarding BIA data cleanup. ${ }^{19}$

Since 1996, the government has spent $\$ 600$ million attempting to reform the trust, but the problems have not been solved. ${ }^{20}$

Because of DOI's persistent mismanagement of IIM trust accounts, Native Americans have not received money that they rightfully and legally earned - money that could be used for education, health care, housing, and other needed services. Billions of dollars owed over time have multiplied the government's obligation to Native Americans and rendered them more reliant on the receipt of funds from external (non-tribal) sources.

DOI, through BIA, provides extensive federal services to Native Americans via numerous financial assistance programs. ${ }^{21}$ A partial list includes aid to tribal governments, social services, resource management, education, alcohol and substance abuse prevention, and public safety and justice (see table

\footnotetext{
${ }^{16}$ Schabner, "\$137 Billion Missing."

${ }^{17}$ Cobell v. Babbitt, 30 F. Supp. 2d 24, 28.

${ }^{18}$ Schabner, "\$137 Billion Missing."

${ }^{19}$ Cobell v. Norton, 226 F. Supp. 2d 1 (D.D.C. 2002); Native American Rights Fund, “Trust Fund Matters,” 2001, $<$ http://www.narf.org/cases/index.html>.

${ }^{20}$ Schabner, "\$137 Billion Missing." According to the DOI, Office of the Budget, substantial progress has been made in records management, education and training, and other areas. See John Trezise, director, Office of Budget, U.S. Department of the Interior, letter to Terri A. Dickerson, assistant staff director, Office for Civil Rights Evaluation, U.S. Commission on Civil Rights, July 16, 2003, re: affected agency review (hereafter cited as Trezise letter).

${ }^{21}$ Aurene Martin, acting assistant secretary, Bureau of Indian Affairs, testimony before the Senate Committee on Indian Affairs, Washington, D.C., Mar. 5, 2003 (hereafter cited as Aurene Martin testimony); U.S. Department of the Interior, "10-Year Accounts History," Sept. 8, 2002 (hereafter cited as DOI, "10-Year Accounts History"). Although DOI provides funds to Native Americans via other bureaus, the focus here is on BIA.
} 
2.1). ${ }^{22}$ In 2002, DOI devoted nearly 25 percent of its budget to Indian nations, communities, and individuals. ${ }^{23}$

As table 2.1 shows, in several instances BIA programs, including Operation of Indian Programs (OIP) and construction, are divided into several program activities, as the federal government labels them. Several program activities are then divided into subprograms, as they are labeled in this report, that can be permanent or temporary. Thus, OIP consists of seven program activities. One of these program activities is other recurring programs, which itself consists of several ongoing or permanent subprograms, such as resource management activities. Another program activity is non-recurring programs, which is a permanent program activity consisting of temporary subprograms that function only until the task they were created for, such as noxious weed eradication, is accomplished (see table 2.2). ${ }^{24}$ The situation is further complicated by the limitations of some programs. For example, the White Earth Settlement Fund serves only one Native American group and thus is not open to other indigenous groups. ${ }^{25}$

Because the array of Native American programs BIA funds is so vast and diverse, this review limits itself to an analysis of OIP, specifically tribal priority allocations (which promote and facilitate selfdetermination), and construction, specifically education construction. ${ }^{26}$

Through the programs presented in table 2.2, BIA assists tribal governments in providing crucial services to their members. For example, tribal priority allocations permit tribal governments to provide after-school care for children whose parents work past the daily dismissal time. These funds also allow tribal governments to provide adult vocational training. The purpose of education construction is to permit BIA-funded schools to provide structurally sound buildings in which Native American children can learn without leaking roofs and peeling paint. ${ }^{27}$

\footnotetext{
${ }^{22}$ See Robert Smith, Office of the Assistant Secretary for Indian Affairs, Office of Alcohol and Substance Abuse Prevention, U.S. Department of the Interior, letter submitted via facsimile, Aug. 8, 2003 (hereafter cited as Smith letter); Trezise letter.

${ }^{23}$ Norton testimony.

${ }^{24}$ Office of Management and Budget, Budget of the United States Government, Fiscal Year 2004, Appendix, pp. 580-89 (hereafter cited as OMB, FY 2004 Budget, Appendix); DOI, "10-Year Accounts History."

${ }^{25}$ OMB, FY 2004 Budget, Appendix, p. 583. The White Earth Settlement Fund is only available to eligible allottees or heirs of the White Earth Reservation in Minnesota.

${ }^{26}$ See OMB, FY 2004 Budget, Appendix, pp. 580-82; U.S. Department of the Interior, Bureau of Indian Affairs, "DOI 1995 Annual Report-Bureau of Indian Affairs,” 1995 (hereafter cited as DOI, “1995 Annual Report-BIA”).

${ }^{27}$ Trezise letter.
} 
TABLE 2.1

DOI Programs and Appropriations for BIA Services to Native Americans, FY 1998-2002

(in thousands of dollars)

\begin{tabular}{|c|c|c|c|c|c|}
\hline & 1998 & 1999 & 2000 & 2001 & 2002* \\
\hline \multicolumn{6}{|l|}{ Current authority } \\
\hline \multicolumn{6}{|l|}{ Definite appropriations } \\
\hline Operation of Indian Programs & $1,529,638$ & $1,585,553$ & $1,648,547$ & $1,788,579$ & $1,799,809$ \\
\hline Construction & 125,279 & 123,421 & 197,404 & 356,618 & 357,132 \\
\hline $\begin{array}{l}\text { Indian land and water claim settlements } \\
\text { and miscellaneous payments to Indians }\end{array}$ & 43,352 & 28,882 & 27,128 & 37,443 & 60,949 \\
\hline Indian Loan Guaranty and Insurance Fund & 0 & 0 & 0 & 0 & 0 \\
\hline Indian Guaranteed Loan Program Account & 5,000 & 5,001 & 4,985 & 4,977 & 4,986 \\
\hline Indian Direct Loan Program Account & 0 & 0 & 0 & 0 & 0 \\
\hline Indian Land Consolidation Pilot & 0 & 5,000 & $(\mathrm{OST})^{\star *}$ & (OST) & (OST) \\
\hline Technical assistance of Indian enterprises & 0 & 0 & 0 & 0 & 0 \\
\hline Total, current appropriations & $1,703,269$ & $1,747,857$ & $1,878,064$ & $2,187,617$ & $2,222,876$ \\
\hline Total, current authority & $1,703,269$ & $1,747,857$ & $1,878,064$ & $2,187,617$ & $2,222,876$ \\
\hline Total, constant 2003 dollars & $1,878,276$ & $1,897,159$ & $1,987,206$ & $2,263,888$ & $2,265,206$ \\
\hline \multicolumn{6}{|l|}{ Permanent authority } \\
\hline \multicolumn{6}{|l|}{ Indefinite appropriations } \\
\hline Construction & 0 & 0 & 0 & 0 & 0 \\
\hline White Earth Settlement Fund & 1,830 & 1,745 & 1,456 & 2,000 & 2,000 \\
\hline Operation and maintenance of quarters & 5,197 & 5,059 & 4,786 & 5,131 & 5,183 \\
\hline $\begin{array}{l}\text { Indian Loan Guarantee and Insurance } \\
\text { Fund, liquidating }\end{array}$ & 11,000 & 1,000 & 1,000 & 1,000 & 1,000 \\
\hline Indian Loan Guarantee default payment & 0 & 0 & 0 & 0 & 1,375 \\
\hline $\begin{array}{l}\text { Land and Water Rights Settlements } \\
\text { Fund and miscellaneous payments }\end{array}$ & 0 & 0 & 0 & 0 & 0 \\
\hline Payments to Tribal Economic Recovery Fund & 0 & 0 & 0 & 0 & 0 \\
\hline Tribal Economic Recovery Fund & (OST) & (OST) & (OST) & (OST) & (OST) \\
\hline Indian Direct Loan Program default payment & 228 & 877 & 6,295 & 79 & 4,251 \\
\hline Revolving Fund for Loans, liquidating & $\begin{array}{l}\text { (Offsetting } \\
\text { collection)^ }\end{array}$ & $\begin{array}{l}\text { (Offsetting } \\
\text { collection) }\end{array}$ & $\begin{array}{l}\text { (Offsetting } \\
\text { collection) }\end{array}$ & $\begin{array}{l}\text { (Offsetting } \\
\text { collection) }\end{array}$ & $\begin{array}{l}\text { (Offsetting } \\
\text { collection) }\end{array}$ \\
\hline Miscellaneous permanent appropriations & 76,541 & 72,929 & 69,762 & 80,498 & 81,412 \\
\hline Total, permanent appropriations & 94,796 & 81,610 & 83,299 & 88,708 & 95,221 \\
\hline Total, Bureau of Indian Affairs & $1,798,065$ & $1,829,467$ & $1,961,363$ & $2,276,325$ & $2,318,097$ \\
\hline Total, constant 2003 dollars & $1,982,813$ & $1,985,740$ & $2,075,346$ & $2,355,689$ & $2,362,241$ \\
\hline
\end{tabular}


TABLE 2.2

BIA Programs, Program Activities, and Subprograms

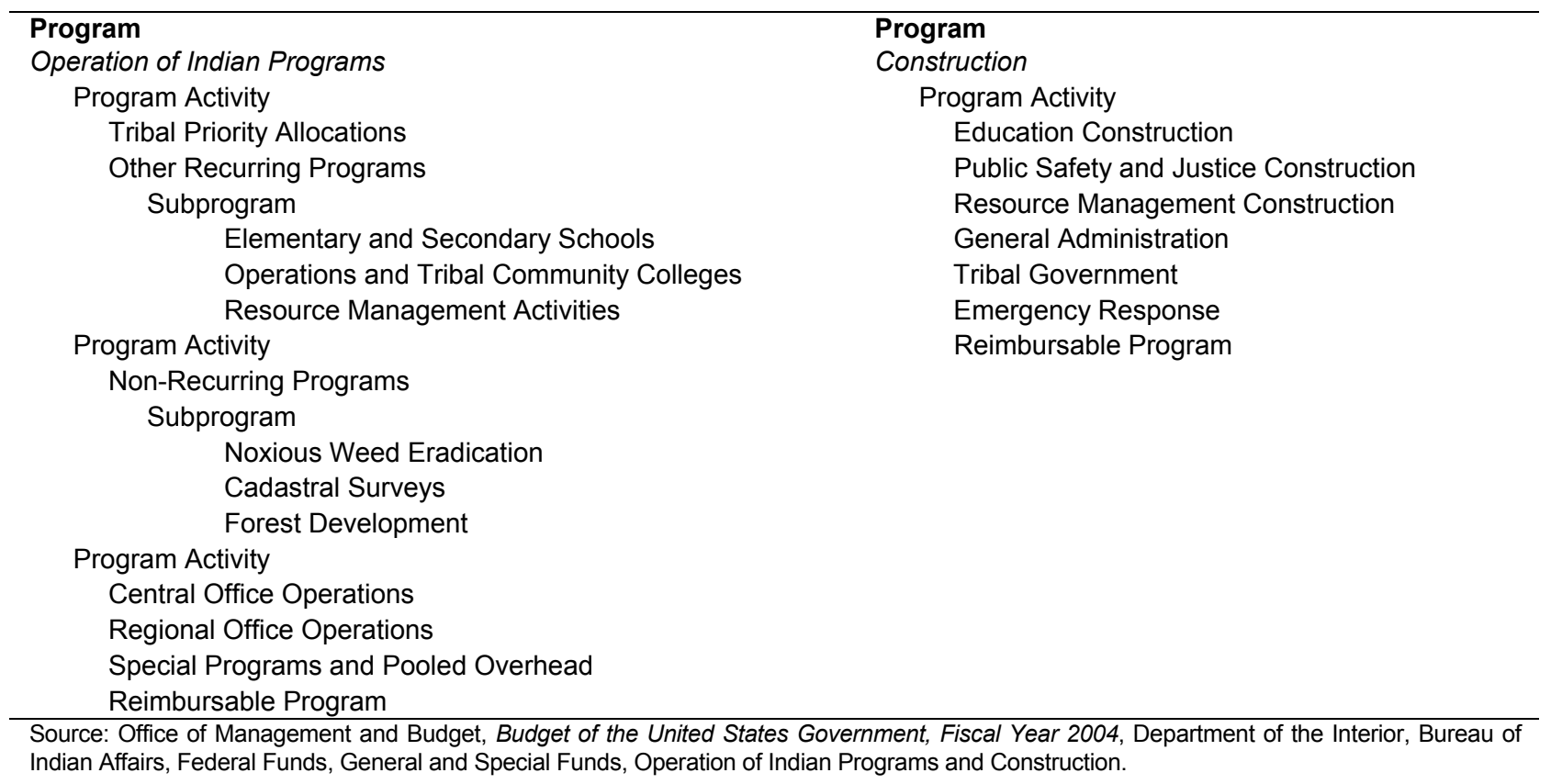

\section{BIA Funding}

From 1998 to 2001, BIA's appropriation increased annually. Between 1998 and 1999, it increased $\$ 45$ million or 2.6 percent, while the next year it increased $\$ 130$ million or 7.4 percent. The largest increase during this period occurred between 2000 and 2001, when BIA's appropriation rose $\$ 310$ million or 16.5 percent. DOI's estimated budgets for 2002 and 2003 show this trend continuing, although at a slower rate (see table 2.3). ${ }^{28}$

BIA's share of DOI's budget has not mirrored this trend. Since peaking at a 22.1 percent share in 2000 , it declined to a 21.2 percent share in 2001; the same percentage estimated for 2002. DOI estimates that in 2003 BIA may again receive a 22.1 percent share, with the 2004 budget proposal providing a 22.7 percent share of DOI's budget (see table 2.3 ). ${ }^{29}$

\footnotetext{
${ }^{28}$ DOI, "10-Year Accounts History."

${ }^{29}$ Office of Management and Budget, Budget of the United States Government, Fiscal Year 1998, Budget, tables S-6, S-7, and 5.4; Office of Management and Budget, Budget of the United States Government, Fiscal Year 1999, Budget, tables S6, S-7, and 5.4; Office of Management and Budget, Budget of the United States Government, Fiscal Year 2000, Budget, tables S-6, S-7, and 5.4 (hereafter cited as OMB, FY 2000 Budget); Office of Management and Budget, Budget of the United States Government, Fiscal Year 2001, Budget, tables S-6, S-7, and 5.4 (hereafter cited as OMB, FY 2001 Budget); Office of Management and Budget, Budget of the United States Government, Fiscal Year 2002, Budget, tables S-6, S-7, and 5.4 (hereafter cited as OMB, FY 2002 Budget); Office of Management and Budget, Budget of the United States Government, Fiscal Year 2003, Budget, tables S-6, S-7 (hereafter cited as OMB, FY 2003 Budget); Office of Management and Budget, Budget of the United States Government, Fiscal Year 2003, Historical Tables, table 5.4; Office of Management and Budget, Budget of the United States Government, Fiscal Year 2004, Budget, tables S-6, S-7 (hereafter after cited as OMB, FY 2004 Budget); Office of Management and Budget, Budget of the United States Government, Fiscal Year 2004, Historical Tables, table 5.4.
} 
TABLE 2.3

BIA Total Budget and as a Percentage of DOl's Discretionary Budget Authority, FY 1998-2004 (in millions of dollars)



Despite a fluctuating percentage of DOI's budget, rising appropriations initially appear to bode well for BIA funding of Native American programs over the period examined here. As seen below, however, numerous programs have suffered budget cuts. The 2003 budget, for example, cuts $\$ 4$ million in welfare assistance for Indian families, and reduces funding for BIA construction by $\$ 11.9$ million and for tribal colleges by $\$ 2$ million from 2002 levels. $^{30}$

Funding cuts and the reallocation of funds for non-tribal use increase unmet needs in Indian Country. A prime example is the amount of BIA funds directed to public schools for the education of Native American students via the Johnson O'Malley (JOM) scholarship program. This scholarship limits funding to $\$ 85$ per student based on criteria established by the tribal priority allocations (TPA) system, discussed below, and a 1995 count of the number of Native American students per state. According to the state of California, between 1995 and 2000 the Native American population in California grew by 38 percent, but BIA continues to provide $\$ 85$ per student based on the 1995 count. Furthermore, the 1995 count excluded a large number of Native American students. Consequently, BIA is not meeting the education needs of Native American students in California or likely in other states since the same criteria are used. ${ }^{31}$

The problem in California is longstanding and occurs nationally. According to the National Congress of American Indians (NCAI) and the National Indian Education Association (NIEA), in 1999, for example, funding for JOM was $\$ 18$ million despite a growing Native American student population that required funding of between \$24 million and \$25 million. Based on the lower figure, Native American students required at least another $\$ 6$ million or 33.3 percent above the $\$ 18$ million alloca-

\footnotetext{
${ }^{30}$ National Congress of American Indians, "House Interior Appropriations Subcommittee Approves FY 2003 Spending Bill," NCAI News (Broadcast \# 02-046), June 25, 2002; Brian Stockes, "President's New Budget Offers Little for Tribal Programs," Indian Country Today, Jan. 23, 2002, <http://www.indiancountry.com/?1013439180>.

31 California School Boards Association, "Recommendations from the CSBA American Indian Student Issues Task Force,” May 3, 2002, <http://www.csba.org/is/am_indians/recommendations.htm>.
} 
tion if their needs were to be adequately addressed. ${ }^{32} \mathrm{JOM}$ funding per student is currently 65.4 percent less than it was during the early 1970s, when per student funding averaged \$246. During that time, Alaska (the state with the highest allocation) received \$1,168 per student, Arizona \$251 per student, New Mexico \$188 per student, and Nevada (the state with the lowest allocation) \$71 per student. ${ }^{33}$

Inadequate funding is scheduled to continue into 2004 in several programs, including TPA and initiatives supporting public safety, education, and economic development. Although TPA is targeted for an additional $\$ 5$ million, it requires $\$ 25$ million or 400 percent more funding than has been proposed. ${ }^{34}$ Moreover, increases for some programs have correlated with decreases in others. A proposed increase of $\$ 169$ million for trust management and related activities of Native American accounts is derived from a reduction in other BIA programs. ${ }^{35}$ It should be noted that DOI disputes this assessment and states that no BIA programs have been reduced to increase funding for trust management. ${ }^{36}$ However, a decrease in BIA program funding is evident. For example, the facilities improvement and repair program is slated for a $\$ 16.2$ million decrease from 2003 , as these funds will be transferred to the replacement school construction program. ${ }^{37}$

Perhaps the clearest example of unmet needs among Native Americans is the disparity between the amounts spent per student at BIA schools compared with public schools. In 2004, BIA schools will spend about $\$ 3,000$ per student, less than half the amount that public schools nationally will spend. ${ }^{38}$ In fact, early estimates for the 2001-2002 school year indicate that, nationally, public schools spent $\$ 7,524$ per student during that year, 150 percent more than BIA schools will spend per student roughly three years later. ${ }^{39}$ The amount currently spent per student at BIA schools is equivalent to public school per student expenditures during the 1983-1984 school year. Thus, in the coming school year BIA schools will spend an amount per student that public schools were spending 20 years ago. ${ }^{40}$ The year 2004 will mark the seventh straight year that only $\$ 3,000$ has been allocated per student at BIA schools; thus inflation has not been factored into funding levels, despite that BIA schools are subject to the same economic conditions as other schools. ${ }^{41}$

\footnotetext{
${ }^{32}$ W. Ron Allen, president, National Congress of American Indians, testimony before the Senate Committee on Indian Affairs, Feb. 24, 1999 (hereafter cited as Allen testimony, Feb. 24, 1999), p. 9; National Indian Education Association, testimony before the Senate Committee on Indian Affairs, Washington, D.C., Feb. 25, 1998, <http://Indian.senate.gov/ 1998hrgs/0225 jc.htm>.

33 Joe H. Herrera, "Candid Comments on Bureaucratic Education,” Journal of American Indian Education, vol. 11, no. 3 (May 1972), <http://jaie.asu.edu/v11/V11S3can.html>.

${ }^{34}$ Hall testimony.

35 Ibid.

${ }^{36}$ Trezise letter.

${ }^{37}$ Senator Pete Domenici, "Domenici: Lean Bush Budget Shows Benefits, Funding Increases for New Mexico (Part II)," news release, Feb. 3, 2003, <http://domenici.senate.gov/newscenter/record.cfm?id=190136>.

${ }^{38}$ David Melmer, "NCAI President Tex Hall Asks Cooperation for Indian Country," Indian Country Today, Feb. 7, 2003, $<$ http://www.indiancountry.com/?1044632117> (hereafter cited as Melmer, "Cooperation for Indian Country"); Thomas E. Atcitty, president, the Navajo Nation, testimony before the Senate Select Committee on Indian Affairs, Washington, D.C., June 10,1998 (hereafter cited as Atcitty testimony, 1998). According to DOI, funding for BIA schools is based on a weighted student unit (WSU), where one student is equivalent to about 1.8 WSU. The 2004 budget proposal provides $\$ 4,029$ for each of the 86,733 WSUs, which would equate to about \$7,294 in BIA funding per Native American student. See Trezise letter.

${ }^{39}$ U.S. Department of Education, National Center for Education Statistics, "Early Estimate of Public Elementary and Secondary Education Statistics: School Year 2001-02," April 2002, pp. 2, 9.

${ }^{40}$ U.S. Department of Education, National Center for Education Statistics, "Digest of Education, 1995," Indicator 30. Pupil/ Teacher Ratios and Expenditures per Student, 1998, <http://nces.gov/pubs98/yi/y9630a.asp>.

${ }^{41}$ Melmer, "Cooperation for Indian Country"; Atcitty testimony, 1998.
} 
When adjusting BIA's appropriations for inflation between 1975 and 2000, the Congressional Research Service found that BIA and the Office of the Special Trustee experienced a yearly decline of $\$ 6$ million despite a budget that indicated an average annual increase of $\$ 46$ million. ${ }^{42}$ BIA's budget has historically been inadequate to meet the needs of Native Americans and, consequently, their needs have multiplied. The 2004 BIA budget fails to fund tribes at the rate of inflation, thus exacerbating the hardships faced by Native American communities. For example, the Gay Head Wampanoag Tribe on the island of Martha's Vineyard, Massachusetts, has received level funding from BIA for five years and has been unable to keep up with rising costs. ${ }^{43}$ In 2000, unmet needs in Indian Country owing to inadequate BIA funding were estimated at $\$ 7.4$ billion and have grown since then. ${ }^{44}$

\section{TABLE 2.4}

Comparison of DOI and BIA Budgets in Constant 2003 Dollars, FY 1998-2004 (in millions of dollars)

\begin{tabular}{|c|c|c|c|c|c|c|c|}
\hline & 1998 & 1999 & 2000 & 2001 & $2002^{*}$ & $2003^{*}$ & $2004^{* *}$ \\
\hline Department of the Interior & 8,100 & 8,000 & 8,500 & 10,300 & 10,500 & 10,200 & 10,600 \\
\hline In constant 2003 dollars & 8,932 & 8,683 & 8,993 & 10,659 & 10,700 & 10,200 & 10,405 \\
\hline Average annual funding, 1998-2003 & \multicolumn{7}{|c|}{$\$ 9,267$} \\
\hline $\begin{array}{l}\text { Average annual funding in constant } \\
2003 \text { dollars, 1998-2003 }\end{array}$ & \multicolumn{7}{|c|}{$\$ 9,695$} \\
\hline Change, 1998-2003 & \multicolumn{7}{|c|}{$\$ 2,100$ or $26 \%$} \\
\hline \multicolumn{2}{|l|}{ Change in constant 2003 dollars, 1998-2003 } & \multicolumn{5}{|c|}{$\$ 1,268$ or $14.2 \%$} & \\
\hline Bureau of Indian Affairs & 1,703 & 1,748 & 1,878 & 2,188 & 2,223 & 2,246 & 2,403 \\
\hline In constant 2003 dollars & 1,878 & 1,897 & 1,987 & 2,264 & 2,265 & 2,246 & 2,359 \\
\hline Average annual funding, 1998-2003 & \multicolumn{7}{|c|}{$\$ 1,998$} \\
\hline $\begin{array}{l}\text { Average annual funding in constant } \\
2003 \text { dollars, 1998-2003 }\end{array}$ & \multicolumn{7}{|c|}{$\$ 2,098$} \\
\hline Change, 1998-2003 & \multicolumn{7}{|c|}{$\$ 543$ or $31.9 \%$} \\
\hline Change in constant 2003 dollars, 1998-2003 & \multicolumn{7}{|c|}{$\$ 368$ or $19.6 \%$} \\
\hline
\end{tabular}

* Estimated. The Department of the Interior Office of Budget and Bureau of Indian Affairs Budget Office informed the Commission that actual budget numbers for fiscal years 2002 and 2003 were not available.

** 2004 budget proposal.

Sources: Office of Management and Budget, Budget of the United States Government, Fiscal Years 2000-2004, Analytical Perspectives, tables S-6, S-7, and 5.4; U.S. Department of the Interior, "Department of Interior Appropriations History Table, Department of Interior-10-Year Accounts History," Sept. 8, 2002, submitted via e-mail, Jan. 9, 2003.

The analysis that follows focuses on two BIA programs: Operation of Indian Programs (OIP), specifically tribal priority allocations, and construction, specifically education construction, to determine whether BIA has satisfied its obligation to Native Americans.

\footnotetext{
${ }^{42}$ Hall testimony. Established by the American Indian Trust Fund Management Reform Act of 1994 (Public Law $103-$ 412), the Office of the Special Trustee for American Indians (OST) was created to improve the accountability and management of Indian funds held in trust by the federal government.

${ }^{43}$ E.S. Dempsey, "USET Impact Week: Tribes Being Left Out Again,” Indian Country Today, Feb. 14, 2003, <http:// www.indiancountry.com/?1045241141> (hereafter cited as Dempsey, "USET").

${ }^{44}$ Susan Masten, president, National Congress of American Indians, testimony before the Senate Committee on Indian Affairs, Feb. 23, 2000, p. 2 (hereafter cited as Masten testimony, 2000).
} 


\section{BIA Funding of Native American Programs}

OIP and construction are the two highest funded programs at BIA. In 2002, OIP received $\$ 1.8$ billion or 78.3 percent of BIA's $\$ 2.3$ billion budget. ${ }^{45}$ The President's 2003 budget requested $\$ 1.9$ billion for OIP, 82.6 percent of BIA's $\$ 2.3$ billion budget. ${ }^{46}$ Construction is the second highest, and in 2000 this program received 10.1 percent or $\$ 200$ million of BIA's \$2 billion budget; in 2001, this program accounted for $\$ 357$ million or 15.5 percent of BIA's $\$ 2.3$ billion budget. ${ }^{47}$ Together, these programs account for \$2.3 billion or 93 percent of BIA's \$2.4 billion 2004 budget request. ${ }^{48}$

\section{Operation of Indian Programs}

OIP is a BIA program consisting of seven program activities: (1) tribal priority allocations; (2) other recurring programs; (3) non-recurring programs; (4) central office operations; (5) regional office operations; (6) special programs and pooled overhead; and (7) reimbursable program (see table 2.2 above). ${ }^{49}$ The OIP program activity funded at the highest level from 1998 through the estimated 2004 budget is tribal priority allocations. As stated by a former BIA assistant secretary, "Tribal Priority Allocations . . . comprises the majority of the Bureau's operating budget and provides the principal source of funds for local units of Tribal Government, most of which are small and lack independent resources to meet the increasing costs of tribal government operation." ${ }^{50}$ More specifically, TPA funds are used to provide such basic tribal services as social services, child welfare, law enforcement, natural resource management, and adult vocational training. ${ }^{51}$

BIA provides TPA support to tribes either by funding tribally operated activities or through direct services. Costs include management and administration. A portion of TPA funds pays government employees who become displaced when tribes choose to operate their own activities. BIA distributes TPA funds to tribes, not individual Native Americans, based on the tribe's reported service population. ${ }^{52}$ Thus, not all Native Americans benefit from TPA funding; tribes have varying definitions of who meets eligibility requirements for BIA-funded services. As such, per person benefits from TPA allocations is a complex calculation that cannot be extrapolated from population estimates alone.

The service population for many tribes residing on reservations consists of the "number of Indian people living on or near tribal lands who are eligible for services from the tribe or BIA." ${ }^{53}$ Communities located in counties adjacent to reservations are those that BIA considers to be "near tribal lands,"

\footnotetext{
${ }^{45}$ DOI, "10-Year Accounts History."

${ }^{46}$ Neal A. McCaleb, former assistant secretary, Bureau of Indian Affairs, testimony before the Senate Committee on Indian Affairs, Mar. 14, 2002 (hereafter cited as McCaleb testimony). The Department of Interior Office of Budget and Bureau of Indian Affairs Budget Office informed the Commission that budget numbers for fiscal year 2003 were not available.

${ }^{47}$ DOI, "10-Year Accounts History."

${ }^{48}$ U.S. Department of the Interior, "Fiscal Year 2004, The Interior Budget in Brief," Table of Contents, Bureau Highlights, Bureau of Indian Affairs, <http://www.doi.gov/budget/2004/04Hilites/toc.html>.

${ }^{49}$ OMB, FY 2004 Budget, Appendix, pp. 580-89.

${ }^{50}$ McCaleb testimony.

${ }^{51}$ U.S. General Accounting Office, "Indian Programs: Tribal Priority Allocations Do Not Target the Neediest Tribes," July 1998, p. 3.

${ }^{52}$ U.S. General Accounting Office, “Indian Issues: BIA’s Distribution of Tribal Priority Allocations,” April 1998, pp. 1, 4-5 (hereafter cited as GAO, "Indian Issues").

${ }^{53}$ U.S. Department of the Interior, Bureau of Indian Affairs, "Report on Tribal Priority Allocations,” July 1999 , p. 18.
} 
and, thus, eligible for services. ${ }^{54}$ Most tribes also require heritage that demonstrates at least onequarter Indian blood for tribal membership and eligibility for services. Tribes in the Muskogee and Anadarko TPA distribution areas of Oklahoma define the service population based on last affiliation with a reservation since these tribes do not have reservations in Oklahoma. In some instances, this definition results in a larger service area than other reservation tribes because it is not confined by reservation borders. ${ }^{55}$ As of 1998, BIA did not consider the tribal service population figures to be accurate, although it does not provide alternatives. ${ }^{56}$

Between 1998 and 2003, TPA funding totaled $\$ 4.5$ billion, a yearly average of $\$ 749$ million. ${ }^{57}$ Since 1998, the percentage of BIA funds provided to TPA has declined such that, for 2004, it will be lower than at any other point except 2001. In 1998, TPA received 42 percent of BIA's budget. By 2001, however, it was receiving only 33 percent, a decrease of 9 percent. Although TPA was receiving more dollars in 2001 (\$759 million) than in 1998 (\$754 million), if its proportion of BIA's budget had remained at 42 percent, its 2001 budget would have been $\$ 966$ million or 27.3 percent more. In 2004, TPA's allocation will be 33.3 percent of BIA's budget if the President's budget request is enacted. Thus, although TPA may receive $\$ 800$ million in 2004 , had its proportion of BIA's budget remained at 1998 levels, it would be funded at $\$ 1$ billion or 25 percent more (see table 2.5). This amount would exceed the \$25 million NCAI believes is required for TPA above the President's request in 2004. The President's 2004 budget requests a \$5 million increase over 2003, \$20 million less than recommended by NCAI. ${ }^{58}$

TPA funding has been so inadequate that it is estimated that its programs in Indian Country still needed $\$ 2.8$ billion in 2000 . According to NCAI, inadequate TPA funding reaches back two decades and has prevented tribes from exercising self-determination and self-governance. ${ }^{59}$ Adult education is among the TPA programs severely affected by funding shortfalls. In 1998, for example, NCAI reported that adult education had been one of the most underfunded Indian programs for numerous years. ${ }^{60}$ In 2000, NCAI stated that the $\$ 2.6$ million program funding level would not meet the adult education needs of Indian Country and that funding must double to $\$ 5$ million. ${ }^{61}$ Despite NCAI's declaration, for 2001, program funding was reduced by more than $\$ 100,000$ from the previous year. ${ }^{62}$

When adjusting for inflation, the impact of TPA funding shortfalls becomes more evident. The TPA budget has diminished the real spending power of tribal governments dramatically, as they have not received funds to compensate for inflation (see table 2.5). Over the period examined in this report, TPA spending power has lost $\$ 36.5$ million or 4.4 percent. ${ }^{63}$ Moreover, Congress has minimally, if at

\footnotetext{
${ }^{54}$ Ibid.

${ }^{55}$ Ibid., p. 18. In fiscal year 1998, Aberdeen, Albuquerque, Anadarko, Billings, Eastern, Juneau, Minneapolis, Muskogee, Navajo, Phoenix, Portland, and Sacramento made up the TPA distribution areas.

${ }^{56}$ GAO, "Indian Issues,” pp. 1, 4-5.

${ }^{57}$ OMB, FY 2000 Budget, Appendix, pp. 581-91; OMB, FY 2001 Budget, Appendix, pp. 588-98; OMB, FY 2002 Budget, Appendix, pp. 591-600; OMB, FY 2003 Budget, Appendix, pp. 579-88; OMB, FY 2004 Budget, Appendix, pp. 580-89.

${ }^{58}$ Hall testimony.

${ }^{59}$ Masten testimony, 2000, pp. 2, 7.

${ }^{60}$ National Congress of American Indians, testimony before the Senate Committee on Indian Affairs, Feb. 25, 1998, $<$ http://indian.senate.gov/1998hrgs/0225 jc.htm>.

${ }^{61}$ Allen testimony, Feb. 24, 1999, p. 9.

${ }^{62}$ Masten testimony, 2000, p. 9.

${ }^{63}$ OMB, FY 2000 Budget, Appendix, pp. 581-91; OMB, FY 2001 Budget, Appendix, pp. 588-98; OMB, FY 2002 Budget, Appendix, pp. 591-600; OMB, FY 2003 Budget, Appendix, pp. 579-88; OMB, FY 2004 Budget, Appendix, pp. 580-89.
} 
all, increased TPA funding over the last decades, thus hindering the full attainment of selfdetermination and self-governance goals. ${ }^{64}$

TABLE 2.5

BIA Funding of Tribal Priority Allocations, FY 1998-2004 (in millions of dollars)

Annual funding, 1998-2003

Annual funding in constant 2003

dollars, 1998-2003

\begin{tabular}{ccccccc}
1998 & $\mathbf{1 9 9 9}$ & $\mathbf{2 0 0 0}$ & $\mathbf{2 0 0 1}$ & $\mathbf{2 0 0 2}$ & $\mathbf{2 0 0 3}^{\boldsymbol{*}}$ & $\mathbf{2 0 0 4}^{\text {** }}$ \\
\hline 754.0 & 681.0 & 705.0 & 759.0 & 801.0 & 795.0 & 800.0 \\
831.5 & 739.2 & 746.0 & 785.5 & 816.3 & 795.0 & 785.3
\end{tabular}

Average annual funding, 1998-2003

$\$ 749.2$

Average annual funding in constant

2003 dollars, 1998-2003

$\$ 785.6$

Change, 1998-2003

$\$ 41.0$ or $5.4 \%$

Change in constant 2003 dollars, 1998-2003

Total funding, 1998-2003

$(\$ 36.5)$ or $(4.4 \%)$

Total funding in constant 2003

dollars, 1998-2003

Percent of BIA's budget

Note: Numbers are rounded.

* Estimated. At the time this report was drafted, actual budget numbers for fiscal year 2003 were not yet available.

** 2004 budget proposal.

Source: Office of Management and Budget, Budget of the United States Government, Fiscal Years 2000-2004, Department of the Interior,

Bureau of Indian Affairs, Federal Funds, General and Special Funds, Operation of Indian Programs.

The limited attainment of self-determination and self-governance because of insufficient funding has been addressed by GAO, a tribal workgroup, and the House of Representatives Resources Committee. The Cherokee Nation is among those tribes experiencing roadblocks to complete self-determination because of inadequate TPA funding. At no time since it entered into a self-governance compact with DOI has the Cherokee Nation received the full share of funding it was guaranteed for contract support costs. In 1999, for example, BIA did not provide the Cherokee Nation with $\$ 250,000$ in indirect costs and failed to provide any direct contract costs despite a legal obligation to do so. ${ }^{65}$ In 2001 , the Cherokee Nation received $\$ 4.3$ million from a lawsuit it filed against DOI for BIA's failure to provide full funding for contract support costs from 1989 through 1993. The Cherokee Nation states that contract support costs from 1993 to the present must still be addressed. ${ }^{66}$

The Cherokee is but one tribe among many encountering barriers to self-determination because of inadequate funds, according to GAO. Many tribes have had to cope with deteriorating governmental infrastructure (e.g., personnel, computer systems, and accounting systems) and resulting limitations because of insufficient TPA funds. Tribal governments also have lost opportunities to improve their communities' economic conditions because the necessary funds have not been available when required, but instead diverted to cover TPA funding shortfalls. Another obstacle to self-determination has been a reduction in program services because TPA funds have not been sufficient to maintain

\footnotetext{
${ }^{64}$ James T. Martin, executive director of United South and Eastern Tribes Inc., testimony before the Senate Committee on Indian Affairs, Washington, D.C., Feb. 26, 1998 (hereafter cited as James T. Martin testimony, Feb. 26, 1998).

${ }^{65}$ Brian Stockes, "Funding Points to a Crisis in Self-Determination," Indian Country Today, May 24, 2000, $<$ http://www.indiancountry.com/?834>. Direct program costs are those that can be identified specifically with a particular contract objective. Indirect costs are those incurred for a common or joint purpose benefiting more than one contract objective, or which are not readily assignable to the contract objectives.

${ }^{66}$ Cherokee Nation, "Cherokee Nation Settles Suit, Nets \$4.3 Million," Mar. 8, 2001, <http://www.cherokee.org/News Archives/Archives2001/3-01-9.htm>.
} 
existing benefits. Lastly, perhaps the gravest impediment to self-determination has been the decision by several tribes to refuse contracting activities because TPA funds simply are not sufficient to cover the costs of running programs. ${ }^{67}$

Reduced spending power has hindered the development of strong and stable tribal governments, which rely on TPA funds to foster economic development in their communities. ${ }^{68}$ Economic development provides tribal governments with a financial foundation to become self-sufficient. Most Native American communities do not have a tax base from which to finance local government, thus when TPA dollars are insufficient, tribes cannot fulfill their governmental obligations. Economic development is critical because it is the only source of generating funds for running tribal governments since most cannot levy taxes on their communities. ${ }^{69}$ The 2004 budget will further impede tribal governments because while funding for some BIA Native American programs will be increased, in others it will be reduced. ${ }^{70}$

\section{Construction}

Construction, like OIP, is a BIA program that consists of seven program activities: (1) education construction; (2) public safety and justice construction; (3) resource management construction; (4) general administration; (5) tribal government; (6) emergency response; and (7) reimbursable program (see table 2.2 above).$^{71}$ By far, the program activity funded at the highest level from 1998 through the estimated 2004 budget is education construction (EC). ${ }^{72}$ EC provides for the planning, design, construction, maintenance, and rehabilitation of BIA-funded school facilities and the repair needs for employee housing. ${ }^{73}$ NIEA arranges these areas under three headings: (1) replacement school construction; (2) facilities repair and improvement (maintenance, rehabilitation, and employee housing); and (3) planning and design. ${ }^{74}$ For ease of discussion, NIEA's format will be used in this chapter.

EC funds the construction of new school buildings, replacement of structurally unsound ones, and repair and maintenance of existing ones. EC is a critical program activity for both BIA and Native American groups. BIA is one of two federal agencies, the other being the Department of Defense (DOD), that manage its own school system. Under the BIA's administration are 185 elementary and secondary schools located in 23 states with an enrollment of almost 48,000 students. BIA operates one-third of the schools directly, while Native American groups operate the rest. ${ }^{75}$

Between 1998 and 2003, EC funding averaged \$166.4 million per year. Total funding over this period was $\$ 999$ million. The percentage of BIA funds directed at EC from 1998 through 2003 in-

\footnotetext{
${ }^{67}$ U.S. General Accounting Office, "Indian Self-Determination Act: Shortfalls in Indian Contract Support Costs Need to Be Addressed," June 1999, p. 39.

${ }^{68}$ James T. Martin testimony, Feb. 26, 1998.

${ }^{69}$ James T. Martin, executive director of United South and Eastern Tribes Inc., testimony before the Senate Committee on Indian Affairs, Washington, D.C., Apr. 9, 1998.

${ }^{70}$ Dempsey, "USET."

${ }^{71}$ OMB, FY 2004 Budget, Appendix, pp. 580-89.

${ }^{72}$ OMB, FY 2000 Budget, Appendix, pp. 581-91; OMB, FY 2001 Budget, Appendix, pp. 588-98; OMB, FY 2002 Budget, Appendix, pp. 591-600; OMB, FY 2003 Budget, Appendix, pp. 579-88; OMB, FY 2004 Budget, Appendix, pp. 580-89.

${ }^{73}$ OMB, FY 2004 Budget, Appendix, p. 582.

${ }^{74}$ National Indian Education Association, "Legislative Update," Feb. 8, 2003, p. 3 (hereafter cited as NIEA, "Legislative Update").

${ }^{75}$ Aurene Martin testimony.
} 
creased substantially. While in 1998 EC was only 3.6 percent of BIA's budget, by 2001 it was 11.8 percent and had increased \$208 million or 325 percent. Although in fiscal year 2002 it declined to 9.2 percent of BIA's budget, compared with 2000 it was \$115 million or 123.2 percent more (see table 2.6) ${ }^{76}$ Perhaps no other Native American program at BIA needed this increase as much as EC because in 2001 the backlog of maintenance that had been deferred stood at $\$ 634$ million. $^{77}$

TABLE 2.6

BIA Funding of Education Construction, FY 1998-2004 (in millions of dollars)

\begin{tabular}{|c|c|c|c|c|c|c|c|}
\hline & 1998 & 1999 & 2000 & 2001 & 2002 & 2003* & $2004^{* *}$ \\
\hline Annual funding, 1998-2003 & 64.0 & 63.0 & 95.0 & 272.0 & 212.0 & 292.6 & 292.6 \\
\hline $\begin{array}{l}\text { Annual funding in constant } 2003 \\
\text { dollars, 1998-2003 }\end{array}$ & 70.6 & 68.4 & 100.5 & 281.5 & 216.0 & 292.6 & 287.2 \\
\hline Average annual funding, 1998-2003 & & & & $\$ 166.4$ & & & \\
\hline $\begin{array}{l}\text { Average annual funding in constant } \\
2003 \text { dollars, 1998-2003 }\end{array}$ & & & & $\$ 171.6$ & & & \\
\hline Change, 1998-2003 & & & & 29 or 357 & & & \\
\hline $\begin{array}{l}\text { Change in constant } 2003 \text { dollars, } \\
\text { 1998-2003 }\end{array}$ & & & & 22 or 314 & & & \\
\hline Total funding, 1998-2003 & & & & $\$ 999$ & & & \\
\hline $\begin{array}{l}\text { Total funding in constant } 2003 \\
\text { dollars, 1998-2003 }\end{array}$ & & & & $\$ 1,030$ & & & \\
\hline Percent of BIA's budget & $3.6 \%$ & $3.5 \%$ & $4.8 \%$ & $11.8 \%$ & $9.2 \%$ & $14.6 \%$ & $12.2 \%$ \\
\hline
\end{tabular}

A few years earlier, in 1998, the repair and replacement backlog of BIA schools had been $\$ 754$ million, with BIA schools in generally poorer physical condition than schools nationally, even those in inner-city neighborhoods. ${ }^{78}$ In 2001 , the Secretary of the Interior stated that, generally, Indian school facilities were in poor condition, with some a century old and exceeding their life expectancy by decades. ${ }^{79}$ In fact, according to BIA, of the 4,495 education buildings in its inventory, half are more than 30 years old, and more than 20 percent are older than 50 years. In 1998, BIA documented 16 buildings that had been erected more than 100 years ago. ${ }^{80}$ BIA education buildings, on average, are 60 years old, while 40 years is the average age for public schools serving the general population. ${ }^{81}$ More significant is the fact that 65 percent of BIA school administrators report one or more school buildings in inadequate physical condition, and 76 percent report inadequate dormitories. By contrast, only 24 percent of public school administrators and 32 percent of DOD school administrators report

\footnotetext{
${ }^{76}$ OMB, FY 2000 Budget, Appendix, pp. 581-91; OMB, FY 2001 Budget, Appendix, pp. 588-98; OMB, FY 2002 Budget, Appendix, pp. 591-600; OMB, FY 2003 Budget, Appendix, pp. 579-88; OMB, FY 2004 Budget, Appendix, pp. 580-89.

77 Aurene Martin testimony.

${ }^{78}$ Senator Tim Johnson, "Johnson Decries Backlog of BIA School Construction During Senate Indian Affairs Committee Hearing," news release, June 10, 1998, <http://johnson.senate.gov/releases/6-10-98biasschool.htm>.

${ }^{79}$ Norton testimony.

${ }^{80}$ John W. Cheek, executive director, National Indian Education Association, testimony before the Senate Committee on Indian Affairs, Washington, D.C., Sept. 6, 2000 (hereafter cited as Cheek testimony, 2000); John W. Cheek, executive director, National Indian Education Association, testimony before the Senate Committee on Indian Affairs, Washington, D.C., Feb. 26, 2003 (hereafter cited as Cheek testimony, 2003).

${ }^{81}$ Cheek testimony, 2003.
} 
buildings in inadequate physical condition. ${ }^{82}$ Although EC allocations have improved dramatically over the last few years, by December 2002, the deferred maintenance backlog was still estimated at \$507 million and increasing. ${ }^{83}$ According to NIEA, deferred maintenance annually increases \$56.5 million (\$22.6 million due to inflation and \$33.9 million due to the natural aging and deterioration of school buildings). ${ }^{84}$

The 2004 budget proposes to fund EC at \$292.6 million, level with 2003, although replacement school construction may increase from $\$ 125.2$ million to $\$ 131.4$ million. ${ }^{85}$ NIEA believes that with the 2004 budget the President continues his commitment to reducing the replacement school construction backlog. Although facilities repair and improvement may decrease \$16.6 million compared with 2003, NIEA believes the reduction is offset by the increase in replacement school construction. ${ }^{86}$ Despite the increase for replacement school construction, with a continuing backlog last estimated at $\$ 507$ million, NIEA believes the President's 2004 budget request for EC overall should have exceeded the 2003 level of $\$ 292.6$ million. ${ }^{87}$

Contributing to the dismal physical condition of most BIA schools are unmet maintenance needs. While the 2004 budget requests $\$ 57.8$ million for facilities maintenance, a $\$ 2$ million increase over the 2003 budget, the NIEA believes minimal funding must be at least \$70 million, $\$ 12.2$ million more than requested. NIEA states that were funding provided under a congressionally mandated needs-based formula, it would exceed $\$ 70$ million. Unmet needs, however, have been a perennial problem as facilities maintenance has been inadequately funded for numerous years. ${ }^{88}$ According to a 1997 GAO report, when maintenance has been provided it has typically been only enough to keep the facility open, not to permanently correct the deficiency. Because of this continuing crisis, 52 percent of BIA schools report deficient ventilation systems, compared with 27 percent of schools serving the general population. Likewise, while 57 percent of BIA schools report problems with the physical security of the building, only 24 percent of all schools report this problem; while 44 percent of BIA schools report problems with heating, only 19 percent of all schools have this problem; while 38 percent of BIA schools report problems with indoor air quality, 19 percent of all schools report this problem. Lastly, while 94 percent of BIA schools report at least one unsatisfactory environmental condition, 50 percent of all schools report at least one such condition. ${ }^{89}$

When adjusted for inflation, the EC budget increased \$222 million or 314.4 percent between 1998 and 2003 (see table 2.6 above).$^{90}$ However, the hazardous structural conditions of the 185 BIA and tribally run schools would have been more quickly addressed had funding been greater. In 2003, for

\footnotetext{
${ }^{82}$ U.S. General Accounting Office, "BIA and DOD Schools: Student Achievement and Other Characteristics Often Differ from Public Schools," September 2001, pp. 23-25, 41-44.

${ }^{83}$ NIEA, "Legislative Update," p. 3; Aurene Martin testimony.

${ }^{84}$ Cheek testimony, 2000.

${ }^{85}$ NIEA, “Legislative Update,” p. 3.

${ }^{86}$ Cheek testimony, 2003. DOI states that these funds have been transferred to the replacement school construction program because a decision was made that it was more cost effective to replace some schools than repair them. See Trezise letter.

${ }^{87}$ NIEA, “Legislative Update," p. 3.

${ }^{88}$ Cheek testimony, 2003.

${ }^{89}$ U.S. General Accounting Office, "School Facilities: Reported Condition and Costs to Repair Schools Funded by Bureau of Indian Affairs,” December 1997, pp. 6-7.

${ }^{90}$ OMB, FY 2000 Budget, Appendix, pp. 581-91; OMB, FY 2001 Budget, Appendix, pp. 588-98; OMB, FY 2002 Budget, Appendix, pp. 591-600. OMB, FY 2003 Budget, Appendix, pp. 579-88; OMB, FY 2004 Budget, Appendix, pp. 580-89; Aurene Martin testimony.
} 
instance, only six schools were scheduled to receive replacement school construction dollars: Santa Fe Indian School, \$15.3 million; Kayenta Board School, \$33.6 million; Tiospa Zina Tribal School, \$13.5 million; Wide Ruins Boarding School, \$21.2 million; Low Mountain Boarding School, \$22.5 million; and St. Francis Indian School, $\$ 14.1$ million. These six schools, along with $\$ 5$ million for the repair of school employee housing, received \$125.2 million or 42.8 percent of the total $\$ 292.6$ million EC budget. ${ }^{91}$ Moreover, although the 2003 EC budget increased $\$ 80.6$ million or 38 percent over 2002, facilities maintenance decreased $\$ 8$ million from 2002. ${ }^{92}$ Therefore, maintaining the proposed 2004 budget at the 2003 level further hinders the EC program's ability to repair all facilities and eliminate the maintenance backlog as quickly as possible. ${ }^{93}$ Old and exceeding their life expectancy by decades, BIA schools require consistent increases in facilities maintenance without offsetting decreases in other programs if 48,000 Native American students are to be educated in structurally sound schools. ${ }^{94}$ Building six new schools in 2001 and repairing six schools in 2003, while progress, is not enough. ${ }^{95}$

Years of delay typically characterize funding for Native American school construction. The Navajo, for instance, had to wait seven years for school construction funds despite being placed on the new construction priority list. The gravity of the situation becomes clear when one realizes that the Navajo estimate that at least half the schools in their system need to be replaced. ${ }^{96}$ The length of time to obtain funding is compounded by the time required for building construction. Native Americans typically wait numerous years before hazardous school buildings are replaced. According to NIEA, despite congressional approval for the construction of 16 schools in 1993, only 13 structures were expected to be completed by 2001 , with construction yet to commence on the remaining three. ${ }^{97}$ However, DOI states that in most cases BIA has no control over how quickly schools get built because funds are contracted out to tribes. ${ }^{98}$

\section{Self-Determination and Self-Governance}

Self-determination and, one of its key components, self-governance are goals of both the federal government and Native Americans. ${ }^{99}$ Despite congressional support for tribal management, tribes wishing to manage programs are beset by inadequate funding and further hindered by the lack of technical assistance and information on the intricacies of self-governance. Funding for the SelfGovernance Communication and Education Project, the source of technical assistance and information for tribes seeking to manage programs, has not increased in real dollars during its 12 years of

\footnotetext{
${ }^{91}$ National Indian Education Association, “Indian Education Legislative Report, 107th Congress, 2nd Session,” Nov. 2-6, 2002, pp. 9, 31.

92 Ibid.

93 Aurene Martin testimony.

${ }^{94}$ Norton testimony; Aurene Martin testimony.

95 Senator Tom Daschle, "Remarks by Senate Democratic Leader Tom Daschle to the 31st Annual Convention of the National Indian Education Association,” Oct. 29, 2000, < http://webarchives.net/remarks_senate_democratic_lea.htm>.

${ }^{96}$ Faye Blueeyes, director of facilities, Shiprock Alternative Schools Inc., testimony before the House Subcommittee on Early Childhood, Youth and Families of the Committee on Education and the Workforce, Washington, D.C., July 20, 1999, <http://commdocs.house.gov/committees/edu/hedcew6-60.000/hedcew6-60.htm>.

${ }^{97}$ Cheek testimony, 2003.

98 Trezise letter.

${ }^{99}$ Eric Henson, Jonathan B. Taylor, et al., Native America at the New Millennium (Cambridge, MA: Harvard University, John F. Kennedy School of Government, Project on American Indian Economic Development, November 2002), pp. 8-9; U.S. Department of the Interior, Bureau of Indian Affairs, "Bureau of Indian Affairs," <http://www.doi.gov/pfm/ar4bia.html> (hereafter cited as DOI, "Bureau of Indian Affairs"); DOI, “1995 Annual Report-BIA.”
} 
existence. For 2004 the NCAI has requested that this program's funding be restored and increased $\$ 100,000 .^{100}$

Inadequate funding of TPA programs, as shown above, has a tremendous impact on Native American governments, the majority of which are small and do not have the option of turning to other sources to meet the increasing costs of government. Native Americans rarely have independent resources to sustain tribal governments, relying instead on funds obtained through BIA. ${ }^{101}$ Since self-determination is paramount in BIA's work with Native Americans, one would expect that TPA would be fully funded every fiscal year. ${ }^{102}$ Yet, in fiscal year 2001, despite a projected 2 percent increase over 2000, TPA contract support costs were funded at 88 percent of need.

\section{Conclusion}

Although BIA funding of Native American programs has increased in real dollars over the period examined here, it has been for the most part inadequate. ${ }^{103}$ The goal of self-determination and selfgovernance demands that all programs be adequately funded. ${ }^{104}$ If tribal governments do not receive the necessary funds, technical assistance, and information for running the programs they manage, it can hardly be expected that indigenous peoples can fully function as sovereign nations. ${ }^{105}$

Unmet needs, as documented above and throughout this report, are all too prevalent among Native Americans. The mismanagement of IIM trust accounts has denied Native Americans basic resources that they were promised in order to meet their needs. Since 1975, subsequent administrations and Congress have neglected their legal obligations to provide full funding for the TPA contract support cost needs of tribally operated BIA programs. ${ }^{106}$ Adding to the crisis is BIA's failure to provide Congress with timely reports fully explaining the nature of TPA contract support costs and shortfalls. Moreover, BIA has withheld program implementation and resources at the area and central office levels, thus preventing them from reaching Native Americans. ${ }^{107}$ The consequences have been reductions in direct program operations, programs that are essential for Native Americans because tribal governments have been unable to cover costs. ${ }^{108}$ The persistent practice of inadequately funding self-determination contracts has also led tribal governments to divert funds for administrative costs; the result is a loss of pro-

\footnotetext{
${ }^{100}$ Hall testimony.

${ }^{101}$ McCaleb testimony.

102 DOI, "Bureau of Indian Affairs”; DOI, “1995 Annual Report-BIA.”

${ }^{103}$ For example, the Office of Alcohol and Substance Abuse Prevention, within the Office of the Assistant Secretary of Indian Affairs at DOI, has historically not been provided sufficient funding to adequately perform its mission of reducing the incidence and prevalence of alcohol and substance abuse in Indian Country. The assistant secretary of Indian affairs reestablished this office in FY 2000. See Smith letter; Office of National Drug Control Policy, "Summary: FY 2002 National Drug Control Budget," IV. Agency Budget Summaries, Department of Interior, Bureau of Indian Affairs, April 2001, $<$ http://www.ncjrs.org/ondcppubs/publications/policy/budget02/partiv_bia.html>.

${ }^{104}$ DOI, "Bureau of Indian Affairs"; DOI, “1995 Annual Report-BIA.”

${ }^{105}$ Hall testimony; Senators Campbell and Inouye, letter to the Senate Committee on the Budget, Feb. $29,2000$.

${ }^{106}$ National Congress of American Indians, "National Policy Workgroup on Contract Support Costs, Second Interim Report," Feb. 1, 1999 <http://www.ncai.org/main/pages/issues/governance/documents/CSreport2.htm> (hereafter cited as NCAI, National Policy Workgroup, Second Interim Report).

${ }^{107}$ National Congress of American Indians, "National Policy Workgroup on Contract Support Costs, Final Report," July $1999<$ http://www.ncai.org/main/pages/issues/governance/documents/CSfinalrep.htm> (hereafter cited as NCAI, National Policy Workgroup, Final Report).

${ }^{108}$ NCAI, National Policy Workgroup, Second Interim Report.
} 
gram resources. ${ }^{109}$ Why this situation continues is perplexing since Congress recognizes that funding shortfalls are the greatest threat to the success of the tribal self-determination policy. ${ }^{110}$

The financial conditions under which BIA Native American programs currently find themselves demand that funding be provided at levels adequate to meet the needs of Native American governments, organizations, and individuals. These conditions can be summarized as follows:

- BIA funding of several Native American programs has been inadequate over the period examined in this report. Between 1975 and 2000, the Congressional Research Service found that BIA and the Office of the Special Trustee had experienced a yearly budget decline of $\$ 6$ million when funding was adjusted for inflation.

- When adjusted for inflation, TPA funding has decreased $\$ 36.5$ million or 4.4 percent between 1998 and 2003. Over the last few decades, Congress funded TPA such that Native American governments and BIA have fallen behind in providing services to Native American communities and families.

- Although education construction funding has increased \$222 million or 314.4 percent even after adjusting for inflation, increased funding would more quickly address the hazardous physical conditions of BIA and tribally operated schools. Despite increased funding, as of December 2002 the replacement school construction backlog stood at \$507 million and is expected to increase. Because BIA and tribally operated schools have been neglected for so long, repairing or building an average of six schools yearly will not address the underlying problems soon enough.

\footnotetext{
${ }^{109}$ NCAI, National Policy Workgroup, Final Report.

${ }^{110}$ NCAI, National Policy Workgroup, Second Interim Report.
} 


\section{Chapter 3: Department of Health and Human Services}

A strong federal commitment to make good on old promises to provide resources for services, prevention programs, and health care facilities is badly needed to turn around the troubling health statistics in Indian Country. ${ }^{1}$

Health service is one of the main responsibilities in the special government-to-government relationship between the United States and federally recognized tribes. The first federal health assistance for Native Americans dates back to 1832, when Congress appropriated $\$ 12,000$ for a health program. By 1880, there were four Native American hospitals, which were run by the Bureau of Indian Affairs. ${ }^{2}$ Forty years later, the Snyder Act of 1921 specifically authorized federal funds "for the relief of distress and conservation of health ... [and] for the employment of . . physicians" for Indian tribes throughout the United States. ${ }^{3}$ In 1954, the responsibility for health care delivery to Native Americans was transferred from the Department of the Interior to the agency today known as the Department of Health and Human Services (HHS). ${ }^{4}$

As social policies have evolved, the federal government has transferred to Native Americans greater authority to manage programs of which they are beneficiaries. The Indian Self-Determination and Education Assistance Act of 1975 gave tribes the choice of whether to take over the administration and operation of health services from the U.S. government or to remain with the government's direct health system. ${ }^{5}$ With the passage of the Indian Health Care Improvement Act of 1976, Congress established the goal of raising "the status of health care for American Indians and Alaska Natives over a seven-year period to a level equal to that enjoyed by other American citizens." ${ }^{6}$ More than 25 years later, this goal is yet unrealized, as Native American health conditions and services remain substandard.

Native Americans have a lower life expectancy - nearly six years less - and higher disease occurrence than other racial/ethnic groups. Roughly 13 percent of Native American deaths occur among those under the age of 25, a rate three times more than that of the total U.S. population. Native American youth are more than twice as likely to commit suicide, and nearly 70 percent of all suicidal acts in Indian Country involve alcohol. ${ }^{7}$ Native Americans are 670 percent more likely to die from

\footnotetext{
${ }^{1}$ Tex Hall, president, National Congress of American Indians, "The State of Indian Nations Today: Mapping a Course for the Next Seven Generations" (State of the Indian Nations Address, Jan. 31, 2003), <http://www.ncai.org> (hereafter cited as Hall, "The State of Indian Nations Today").

${ }^{2}$ U.S. Commission on Civil Rights, Federal Policies and Programs for American Indians, staff report, Albuquerque/Phoenix hearings, November 1972, p. 43 (hereafter cited as USCCR, Federal Policies and Programs for American Indians).

${ }^{3}$ Snyder Act of 1921, ch. 115, 42 Stat. 208 (codified as amended at 25 U.S.C. $\S 13$ (1994)).

${ }^{4}$ Transfer Act of Aug. 5, 1954, Pub. L. No. 89-568, 68 Stat. 674 (codified as amended at 42 U.S.C. § 2001 (1994)). At the time, the agency was known as the Department of Health, Education, and Welfare.

${ }^{5}$ Indian Self-Determination and Education Assistance Act of 1975, Pub. L. No. 93-638, 88 Stat. 2206 (codified in scattered sections of 5 U.S.C. and 25 U.S.C.).

${ }^{6}$ H.R. ReP. No. 94-1026, pt. I, at 13 (1976); Indian Health Care Improvement Act of 1976, Pub. L. No. 94-437, 90 Stat. 1400 (codified as amended in scattered sections of 25 U.S.C.).

${ }^{7}$ Friends Committee on National Legislation, "Quality Health Care for Native Youth," Feb. 28, 2001, <http://www.fcnl. org/issues/nat/sup/indians_health_care.htm>; Friends Committee on National Legislation, "FCNL Letter to Appropriations
} 
alcoholism, 650 percent more likely to die from tuberculosis, 318 percent more likely to die from diabetes, and 204 percent more likely to suffer accidental death when compared with other groups. ${ }^{8}$ These disparities exist because of disproportionate poverty, poor education, cultural differences, and the absence of adequate health service delivery in most Native communities.

One of the largest barriers to adequate health care for Native Americans is access. Only 28 percent of Native Americans have private health insurance through an employer; 55 percent rely on the Indian Health Service (IHS) within HHS for all their health care needs. ${ }^{9}$ According to the National Center for Health Statistics, Native Americans make fewer visits to physicians' offices and hospital outpatient departments than any other racial or ethnic group. In 1999, per 100,000 people, whites made 293 visits to the doctor, Asian Americans made 233 visits, blacks made 211 visits, and Native Americans made only 54. On the other hand, they made more emergency room visits than whites or Asian Americans. ${ }^{10}$

For the last 10 years, HHS has designated more funding to Native American programs than any other federal agency. HHS houses the Indian Health Service, which is the principal federal health care provider and health advocate for Native American people. ${ }^{11}$ All members of federally recognized Indian tribes are eligible for IHS services. IHS serves an estimated 1.6 million (approximately 60 percent) of the 2.5 million Native Americans in the United States. ${ }^{12}$

Because IHS is the primary Native American health care provider, and the agency's largest recipient of Native American-specific funding, it will be the subject of this discussion; however, other agencies within HHS also provide funding for and administer programs to benefit Native peoples. They are the Administration for Children and Families, the Administration on Aging, the Centers for Disease Control and Prevention, and the Substance Abuse and Mental Health Services Administration (see table 3.1 below for a list of programs and funding amounts). The Center for Medicare/Medicaid Services is the second largest resource for Indian health care through its Medicaid, Medicare, and State Children's Health Insurance Programs. ${ }^{13}$ Its expenditures are not, however, included in HHS' funding totals for Native American programs because these benefits are available to the entire eligible U.S. population.

In addition to the direct health services to Native Americans, HHS also funds more than $\$ 1.1$ billion annually in grants to Native American tribes, individuals, and organizations, according to the Catalog of Federal Domestic Assistance. Among the largest projects funded are:

\footnotetext{
Interior Subcommittees re: Increase the FY 2002 Budget for the Indian Health Service," June 6, 2001, <http://www.fcnl. org/issues/nat/sup/indians_health_51801.htm> (hereafter cited as FCNL, "Letter to Appropriations Interior Subcommittees").

${ }^{8}$ Restructuring Initiative Workgroup, Transitions 2002: A 5-Year Initiative to Restructure Indian Health, final report to the Indian Health Service, October 2002, p. 9 (hereafter cited as Restructuring Workgroup, Transitions 2002); see also U.S. Department of Health and Human Services, Indian Health Service, Trends in Indian Health, 1998-99, p. 6 (hereafter cited as IHS, Trends in Indian Health).

${ }^{9}$ Restructuring Workgroup, Transitions 2002, p. 8.

${ }^{10}$ U.S. Census Bureau, Statistical Abstracts of the United States: 2001, table 158, p. 108.

${ }^{11}$ U.S. Department of Health and Human Services, Indian Health Service, "Introduction," <http://www.ihs.gov/About IHS/IHSintro.asp> (hereafter cited as IHS, "Introduction").

12 U.S. Department of Health and Human Services, Indian Health Service, "Fact Sheet," updated Oct. 16, 2002, $<$ http://www.ihs.gov/PublicInfo/PublicAffairs/Welcome_Info/ThisFacts.asp > (hereafter cited as IHS, "Fact Sheet").

13 James Allen Crouch and Cliff Wiggins, co-chairs, Federal Disparity Index Workgroup, letter to Dr. Michael Trujillo, director, Indian Health Service, Mar. 26, 2001, included in "FY 2001 FEHBP Disparity Index and Application of Findings to Allocate the FY 2002 Indian Health Care Improvement Fund,” March 2002 (hereafter cited as Crouch and Wiggins letter).
} 
- Financial assistance awards to Indian tribes to enable them to assume programs, functions, services, and activities of IHS and of the Department of the Interior. These project grant awards result in cooperative agreements between the departments and tribes for the provision of health services.

- Funds to enable Indian tribes to assume the management and operation of health care delivery to Indian people. These grants enable self-determination contracts with Indian tribes or tribal organizations interested in assuming responsibility for the administration and provision of government health services.

- Grants to provide financial assistance, training and technical assistance, and research, demonstration, and evaluation activities to public and private nonprofit organizations. Recipients include tribes, urban Indian centers, Alaska Native villages, Native Hawaiian organizations, rural off-reservation groups, and Native American Pacific Island groups for the development and implementation of social and economic development strategies that promote selfsufficiency. These projects are expected to result in improved social and economic conditions of Native Americans within their communities.

Additional funds are made available for capacity building, tribal work programs, urban health services, health profession scholarships, and health management programs.

The following table depicts HHS funding for programs specifically targeting American Indians and Alaska Natives. In tallying its Native American expenditures, HHS does not include funding for which Native Americans compete with other groups, those for which all individuals are eligible, and those that are awarded to states and then passed on to Native communities. ${ }^{14}$ As a result, and as noted previously, the amount does not include Medicaid and Medicare benefits received by Native Americans.

Between 1998 and 2003, funding for Indian-specific programs increased roughly $\$ 1.3$ billion, an increase of approximately 47 percent. However, after adjusting for inflation, the increase is only slightly more than $\$ 1$ billion. This represents a real increase of roughly 33 percent during the six-year period. During the same period, HHS' overall budget authority increased $\$ 148.3$ billion, a 41 percent increase. After adjusting for inflation, the increase was actually $\$ 112$ billion (from $\$ 396$ billion to $\$ 508$ billion) or roughly 28 percent. ${ }^{15}$ This demonstrates that funding for Indian-specific programs has grown at a slightly faster rate than HHS' overall budget. While this upward trend appears promising, there remains reason to be concerned about its adequacy, particularly upon closer examination of HHS' discretionary budget.

\footnotetext{
${ }^{14}$ U.S. Department of Health and Human Services, Office of the Secretary for Management and Budget, "DHHS Funding for American Indian and Alaska Native Targeted Programs," submitted via facsimile, Feb. 6, 2003.

${ }^{15}$ Office of Management and Budget, Budget of the United States Government, Fiscal Year 2004, Historical Tables, table 5.2, pp. 95-96 (hereafter cited as OMB, FY 2004 Budget). The same composite deflators were used to calculate HHS' overall budget authority in constant 2003 dollars as were used to calculate the agency's funding for Native American programs (see table 3.1).
} 
TABLE 3.1

HHS Program Level Funding for American Indian and Alaska Native Programs, FY 1998-2004

(in thousands of dollars)

\begin{tabular}{|c|c|c|c|c|c|c|c|}
\hline & & & & & & & \\
\hline & 1998 & 1999 & 2000 & 2001 & 2002 & 2003 & $2004^{*}$ \\
\hline Indian Health Service & $2,459,787$ & $2,668,931$ & $2,857,100$ & $3,273,100$ & $3,392,900$ & $3,510,300$ & $3,607,500$ \\
\hline \multicolumn{8}{|l|}{$\begin{array}{l}\text { Admin. for Children } \\
\text { and Families (ACF): }\end{array}$} \\
\hline Head Start & 121,272 & 130,191 & 144,800 & 171,300 & 181,800 & 185,500 & 189,500 \\
\hline $\begin{array}{l}\text { Administration for } \\
\text { Native Americans }\end{array}$ & 34,870 & 34,858 & 35,400 & 46,00 & 45,800 & 45,500 & 45,100 \\
\hline $\begin{array}{l}\text { Low Income Home } \\
\text { Energy Assistance }\end{array}$ & 19,232 & 10,293 & 21,800 & 21,800 & 19,700 & 17,600 & 17,800 \\
\hline Child Care Programs & 61,383 & 63,335 & 71,000 & 92,300 & 96,300 & 96,100 & 96,300 \\
\hline Family Violence & 7,666 & 8,878 & 10,100 & 11,700 & 12,400 & 12,600 & 12,400 \\
\hline $\begin{array}{l}\text { Community Services } \\
\text { Block Grant }\end{array}$ & 3,016 & 3,040 & 3,300 & 3,800 & 3,900 & 4,100 & 3,000 \\
\hline $\begin{array}{l}\text { Promoting Safe and } \\
\text { Stable Families }\end{array}$ & 2,550 & 2,750 & 3,000 & 3,100 & 4,500 & 5,000 & 7,100 \\
\hline Tribal TANF & 5,734 & 16,017 & 19,900 & 50,100 & 102,700 & 110,100 & 114,800 \\
\hline Tribal Work Program & 7,633 & 7,633 & 7,600 & 7,600 & 7,600 & 7,600 & 7,600 \\
\hline Tribal Child Support & N/A & $\mathrm{N} / \mathrm{A}$ & $\mathrm{N} / \mathrm{A}$ & 2,100 & 6,100 & 11,700 & 34,800 \\
\hline Child Welfare Services & 4,035 & 4,683 & 3,900 & 4,500 & 4,500 & 5,300 & 4,500 \\
\hline Subtotal ACF & 267,391 & 281,678 & 320,800 & 414,300 & 485,300 & 501,100 & 532,900 \\
\hline \multicolumn{8}{|l|}{ Admin. on Aging: } \\
\hline Grants to Tribes & 18,457 & 18,457 & 18,500 & 30,400 & 33,200 & 35,600 & 33,200 \\
\hline \multicolumn{8}{|l|}{$\begin{array}{l}\text { Centers for Disease } \\
\text { Control: }\end{array}$} \\
\hline $\begin{array}{l}\text { Preventive Health } \\
\text { Block Grant }\end{array}$ & 94 & 96 & 100 & 100 & 100 & 100 & 100 \\
\hline \multicolumn{8}{|l|}{$\begin{array}{l}\text { Substance Abuse } \\
\text { and Mental Health } \\
\text { Services Admin.: }\end{array}$} \\
\hline $\begin{array}{l}\text { Substance Abuse } \\
\text { Block Grant }\end{array}$ & 490 & 515 & 500 & 500 & 500 & 500 & 500 \\
\hline Total program level ${ }^{\star *}$ & $\$ 2,746,219$ & $\$ 2,969,677$ & $\$ 3,197,000$ & $\$ 3,718,400$ & $\$ 3,912,000$ & $\$ 4,047,600$ & $\$ 4,174,200$ \\
\hline $\begin{array}{l}\text { Total in constant } \\
2003 \text { dollars }\end{array}$ & $\$ 3,028,387$ & $\$ 3,223,348$ & $\$ 3,382,789$ & $\$ 3,848,041$ & $\$ 3,986,498$ & $\$ 4,047,600$ & $\$ 4,097,626$ \\
\hline
\end{tabular}


TABLE 3.2

HHS Total Budget Authority, FY 1998-2004 (in millions of dollars)

\begin{tabular}{|c|c|c|c|c|c|c|c|}
\hline & 1998 & 1999 & 2000 & 2001 & 2002 & 2003 & $2004^{*}$ \\
\hline Actual dollars & 359,536 & 365,297 & 392,449 & 434,966 & 478,722 & 525,067 & 537,683 \\
\hline Constant 2003 dollars ${ }^{* *}$ & 396,478 & 396,501 & 415,256 & 450,131 & 487,838 & 525,067 & 527,819 \\
\hline
\end{tabular}

${ }^{*}$ Estimate based on FY 2004 budget request.

** To adjust for inflation, the composite deflators used by the Office of Management and Budget and provided in the FY 2004 Budget of the United States were used.

Sources: Office of Management and Budget, Budget of the United States Government, Fiscal Year 2004, Historical Tables, table 5.2, pp. 9596; U.S. Department of Health and Human Services, Office of Budget, Division of Budget Policy and Management, "FY 2004 President's Budget," updated numbers submitted via e-mail, Mar. 27, 2003.

\section{FIGURE 3.1}

HHS Budget Authority in Real and Constant Dollars, FY 1998-2004

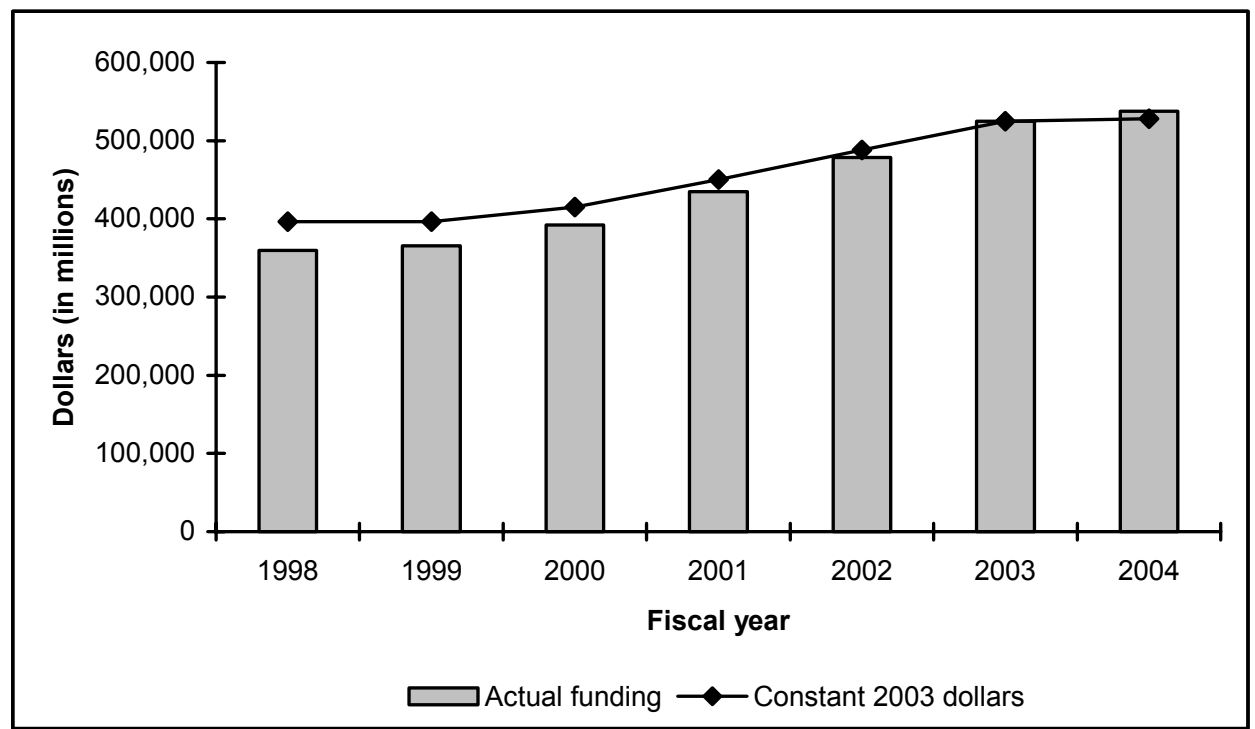

Sources: Office of Management and Budget, Budget of the United States Government, Fiscal Year 2004, Historical Tables, table 5.2, pp. 95-96; U.S. Department of Health and Human Services, Office of Budget, Division of Budget Policy and Management, "FY 2004 President's Budget," updated numbers submitted via e-mail, Mar. 27, 2003.

Federal funding for Indian health care is not statutorily predetermined, but rather depends on annual discretionary appropriations. Thus, tribes receive different amounts depending on needs from year to year, all of which is subject to availability of funds. ${ }^{16}$ Between 1998 and 2003, HHS received an average annual increase in discretionary funds of 11.8 percent (see table 3.3 ). ${ }^{17}$ In constant dollars, the agency's discretionary budget authority increased nearly 58 percent overall from the 1998 level. ${ }^{18}$ Thus, the funding for Native American programs - which is a subset of discretionary appropriations, not HHS' overall budget authority - increased, but significantly less than discretionary programs overall (33 percent compared with 58 percent).

\footnotetext{
${ }^{16}$ U.S. Department of Health and Human Services, Indian Health Service, Level of Need Funded Workgroup, "Level of Need Funded Cost Model," May 1999, p. 2.

${ }^{17}$ OMB, FY 2004 Budget, Budget, table S-17, p. 317.

${ }^{18}$ OMB, FY 2004 Budget, Historical Tables, table 5.4, pp. 103-04.
} 
TABLE 3.3

HHS Annual Discretionary Budget Authority, 1998-2003 (in billions of dollars)

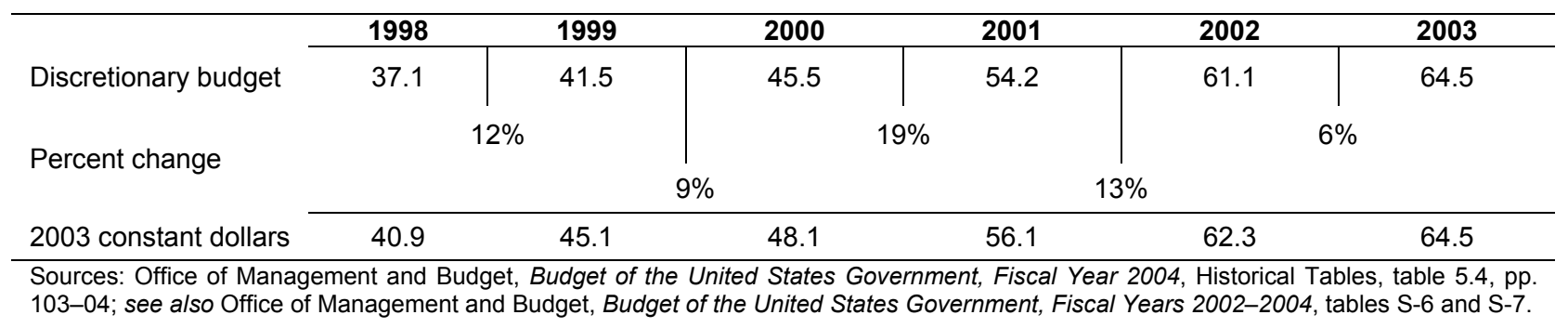

\section{Indian Health Service}

The Indian Health Service was established in 1955 to provide primary health care in Indian Country facilities. IHS counts American Indians, Eskimos, and Aleuts who reside in geographic areas on or near reservations to estimate its service population; the service population comprises about 60 percent of all Native Americans, not all of whom use IHS services. ${ }^{19}$ Approximately 36 percent of the IHS service area population resides in non-Indian regions that are served under contracts with existing health care providers (known as contract service delivery areas). Indian areas are defined as reservations, off-reservation trust lands, Alaska Native Regional Corporations, and Alaska Native village statistical areas. ${ }^{20}$ As noted above, today IHS provides care to 1.6 million American Indians and Alaska Natives, who are members of federally recognized tribes, in 35 states.

IHS employs more than 15,000 individuals; 69 percent of IHS staff is of American Indian or Alaska Native descent. ${ }^{21}$ From its 12 area offices and headquarters based in Washington, D.C., IHS supports 49 hospitals and more than 540 health clinics and other facilities, many of which are locally operated by the tribes themselves under self-determination contracts. In addition, IHS contracts medical care from private health sources, provides preventive health care, funds urban Indian programs, and constructs waste water and solid waste disposal systems in Indian homes and communities. ${ }^{22}$ Most IHS funds are appropriated for Native Americans who live on or near reservations, which are primarily located in rural settings. There are 34 projects providing health care for 330,000 Native Americans living in urban areas. ${ }^{23}$

\footnotetext{
${ }^{19}$ IHS, Trends in Indian Health, p. 13. For counting purposes, IHS relies on the definitions of American Indian, Eskimo, and Aleut used in the census.

${ }^{20}$ U.S. Department of Health and Human Services, Indian Health Service, FY 2004 Budget Request, Justification of Estimates for Appropriations Committees, <http://www.ihs.gov/AdminMngrResources/Budget/FY_2004_Budget_Justification.asp>, p. 93 (hereafter cited as IHS, FY 2004 Budget Request, Justification of Estimates).

${ }^{21}$ IHS, "Fact Sheet"; U.S. Department of Health and Human Services, Indian Health Service, "Year 2002 Profile," January 2002 (hereafter cited as IHS, "Year 2002 Profile").

${ }^{22}$ IHS, "Introduction."

${ }^{23}$ IHS, "Fact Sheet”; IHS, "Year 2002 Profile."
} 
TABLE 3.4

Overview of IHS-Supported Services

\begin{tabular}{cc}
\hline Federal System & Self-Determination Contracts \\
36 hospitals & 13 hospitals \\
63 health centers & 158 health centers \\
44 health stations & 76 health stations \\
5 residential treatment centers & 28 residential treatment centers \\
34 urban Indian health projects & 170 Alaska village clinics \\
\hline Source: U.S. Department of Health and Human Services, Indian Health Service, "Year 2002
\end{tabular}
Profile," January 2002.

Tribes manage approximately 52 percent of the funds appropriated to IHS. ${ }^{24}$ As table 3.4 illustrates, IHS has self-determination contracts with tribes that support more than 440 facilities, from fullservice hospitals to clinics and treatment centers. It is estimated that, in fiscal year 2004, tribal governments, under self-determination contracts and self-governance compacts, will administer \$1.4 billion of IHS' funds. ${ }^{25}$ With the transfer of responsibility to the tribes comes the recognition that tribemanaged health care is more responsive to the needs of individual tribal members than a far-removed federal system. Further, because so many of the chronic health conditions that plague Native Americans have behavioral components, a more comprehensive community-based approach to health care in Indian communities is needed. ${ }^{26}$ This underscores the importance of self-determination contracts and tribal management of health care systems.

In its first year of existence, 1955, IHS' budget was $\$ 24.5$ million. ${ }^{27}$ Today, with a total program level of $\$ 3.5$ billion and a budget authority of roughly $\$ 2.9$ billion, IHS is the single largest funding source for Native American programs, yet its budget accounts for 0.5 percent of HHS' total budget authority (\$525 billion) and only 4.4 percent of HHS' discretionary budget. This underfunding holds true despite an increase of $\$ 91$ million over the 2002 level. As table 3.5 illustrates, the amount of HHS' discretionary budget has increased at a faster rate than IHS' total budget. In 1998, the IHS total budget was 5.6 percent of HHS' discretionary budget, while in 2003 it is 4.4 percent. The proposed FY 2004 IHS budget maintains the current proportion.

\footnotetext{
${ }^{24}$ U.S. Department of Health and Human Services, Office of Budget, FY 2003 President's Budget for HHS, <http://www. hhs.gov/budget/docbudget.htm>, p. 28.

${ }^{25}$ OMB, FY 2004 Budget, Appendix, p. 411.

${ }^{26}$ Eric Hensen, Jonathan B. Taylor, et al., Native America at the New Millennium (Cambridge, MA: Harvard University, John F. Kennedy School of Government, Project on American Indian Economic Development, November 2002 ), p. 126 (hereafter cited as Hensen and Taylor, Native America at the New Millennium).

${ }^{27}$ USCCR, Federal Policies and Programs for American Indians, p. 43.
} 
TABLE 3.5

IHS Budget Authority as a Percentage of HHS Discretionary Authority (in millions of dollars)

\begin{tabular}{|c|c|c|c|c|c|c|c|}
\hline & 1998 & 1999 & 2000 & 2001 & 2002 & 2003 & $2004^{*}$ \\
\hline HHS discretionary & 37,122 & 41,516 & 45,452 & 54,249 & 61,098 & 64,493 & 66,195 \\
\hline IHS budget authority & 2,099 & 2,240 & 2,391 & 2,689 & 2,759 & 2,850 & 2,890 \\
\hline $\begin{array}{l}\text { Percent of total } \\
\text { discretionary funds }\end{array}$ & $5.6 \%$ & $5.4 \%$ & $5.3 \%$ & $5.0 \%$ & $4.5 \%$ & $4.4 \%$ & $4.4 \%$ \\
\hline $\begin{array}{l}\text { IHS budget in constant } \\
2003 \text { dollars }\end{array}$ & 2,315 & 2,431 & 2,530 & 2,783 & 2,812 & 2,850 & 2,837 \\
\hline
\end{tabular}

IHS' budget authority increased $\$ 751$ million between 1998 and 2003, an increase of roughly 35 percent. After adjusting for inflation, the increase was $\$ 535$ million or approximately 23 percent. IHS thus did not receive increases comparable to those HHS received as a whole, nor did its budget grow at the same rate as all Native American programs within the agency.

Most of IHS' budget (86 percent) is spent on health services, including clinical care, preventive health, health professional training, and contract support for health service management transferred to tribes. The remaining is allocated to maintenance and construction of health and sanitation facilities and equipment (see table 3.6).

While other federal health programs, such as Medicare and Medicaid, accrue annual interest to keep pace with inflation, IHS programs do not. ${ }^{28}$ Since 1990, the IHS service population has increased approximately 2.3 percent each year. ${ }^{29}$ Thus, over the five-year period between 1998 and 2003, the service population has increased at least 11.5 percent. During the same period, industry experts estimate that medical costs grew approximately 10 to 12 percent annually. ${ }^{30}$ Even with the funding increases it has received, the IHS budget has not kept pace with the growing service population and escalating health care costs. Consequently, a large and expanding gap exists between needed and available services, or unmet needs, in Native American communities.

\footnotetext{
${ }^{28}$ Julia Davis-Wheeler, chair, National Indian Health Board, testimony before the Senate Committee on Indian Affairs, Washington, D.C., Feb. 26, 2003, p. 6 (hereafter cited as Davis-Wheeler testimony).

${ }^{29}$ IHS, Trends in Indian Health, p. 5.

${ }^{30}$ Judy Nichols, "Indian Health Care: Separate, Unequal," Arizona Republic, Apr. 14, 2002 (hereafter cited as Nichols, "Indian Health Care").
} 
TABLE 3.6

IHS Budget Authority and Program Level Funding, FY 1998-2003 (in millions of dollars)

\begin{tabular}{|c|c|c|c|c|c|c|c|}
\hline & 1998 & 1999 & 2000 & 2001 & 2002 & 2003 & $2004^{*}$ \\
\hline \multicolumn{8}{|l|}{ Health Services } \\
\hline Clinical services & $1,476.9$ & $1,540.4$ & $1,632.3$ & $1,840.0$ & $1,891.9$ & $1,973.8$ & $1,987.1$ \\
\hline Preventive health & 82.8 & 87.1 & 91.9 & 97.4 & 99.7 & 102.6 & 108.3 \\
\hline Contract support costs & 168.7 & 203.8 & 228.8 & 248.2 & 268.2 & 269.0 & 270.7 \\
\hline Urban health & 25.3 & 26.4 & 27.8 & 29.9 & 30.9 & 31.3 & 31.6 \\
\hline Health professions & 28.7 & 29.6 & 30.5 & 30.6 & 31.2 & 31.1 & 35.4 \\
\hline Direct operations & 47.4 & 49.3 & 51.0 & 60.5 & 55.3 & 60.2 & 56.6 \\
\hline Self-governance/Tribal management & 11.5 & 11.8 & 11.9 & 12.2 & 12.3 & 7.9 & 12.7 \\
\hline Subtotal & $1,841.2$ & $1,948.4$ & $2,074.2$ & $2,318.9$ & $2,389.6$ & $2,475.9$ & $2,502.4$ \\
\hline \multicolumn{8}{|l|}{ Indian Health Facilities } \\
\hline Facilities/Environmental health support & 101.6 & 107.7 & $1,16.3$ & 127.3 & 126.8 & 132.3 & 139.5 \\
\hline Health care facilities construction & 14.4 & 41.1 & 50.4 & 85.5 & 86.3 & 81.6 & 69.9 \\
\hline Sanitation facilities construction & 89.1 & 89.3 & 92.1 & 94.7 & 93.8 & 93.2 & 114.2 \\
\hline Maintenance and improvement & 39.4 & 40.6 & 43.4 & 46.3 & 46.3 & 49.5 & 47.3 \\
\hline Medical equipment & 13.0 & 13.2 & 14.3 & 16.3 & 16.3 & 17.2 & 16.3 \\
\hline Subtotal & 257.5 & 292.0 & 316.6 & 370.1 & 369.5 & 373.7 & 387.3 \\
\hline Total budget authority & $2,098.7$ & $2,240.3$ & $2,390.7$ & $2,689.0$ & $2,759.1$ & $2,849.7$ & $2,889.7$ \\
\hline Total program level ${ }^{\star *}$ & $2,459.8$ & $2,668.9$ & $2,857.1$ & $3,273.1$ & $3,393.9$ & $3,510.3$ & $3,607.3$ \\
\hline
\end{tabular}

\section{Unmet Health Needs}

Over the past thirty years there has developed a chronic pattern of underfunding. In recent years, the Congress has failed to provide sufficient funds to address even natural population growth and medical inflation. The resulting erosion of buying power has contributed to the disparity in health status among [American Indian/Alaska Native] communities. ${ }^{31}$

In an earlier report, the Commission found that Native Americans lagged 20 to 25 years behind the general population in health status. ${ }^{32}$ The unmet health care needs of Native Americans remain among the most severe of any group in the United States. Despite their need for health care and although there are designated health services, the monetary value of Native American care is significantly less than the average health expenditure for all Americans. IHS' real spending per Native American, after adjusting for inflation and population growth, has fallen over time, despite funding increases. ${ }^{33}$

According to one health care expert, IHS operates with an estimated 59 percent of what it needs to provide adequate health care. ${ }^{34}$ It is estimated that national per capita health expenditure for the average American will be $\$ 5,775$ in 2003 , and that health care spending will continue to grow at an an-

\footnotetext{
${ }^{31}$ Crouch and Wiggins letter.

${ }^{32}$ USCCR, Federal Policies and Programs for American Indians, p. 44.

${ }^{33}$ Hensen and Taylor, Native America at the New Millennium, p. 129.

${ }^{34}$ Michelle DeArmond, "Caring for Tribal Members," The Press-Enterprise (Riverside, CA), Sept. 15, 2002, p. A1, quoting James Crouch, spokesman, California Indian Health Partnership.
} 
nual rate of 7.3 percent over the next 10 years. ${ }^{35}$ IHS spends $\$ 1,600$ per person per year for comprehensive health services in its hospitals and health clinics, roughly 50 percent below per person expenditures by public and private health insurance plans. ${ }^{36}$ The agency also estimates that in 2003 it will spend roughly $\$ 1,900$ per person for all medical care, including preventive health and clinical services (see figure 3.2). It should be noted that the amount of per capita spending on health care varies greatly among IHS service areas. According to one report, in remote Native villages of Alaska, IHS spends more than $\$ 6,000$ per person annually for health care, while in one area of the Navajo Nation, the largest Native American reservation land base, it spends less than $\$ 800$ annually per person. ${ }^{37}$

Contrasting Native Americans with other populations for whom the federal government has direct responsibility for health care - such as veterans, Medicaid recipients, and federal prison inmatesdistinct disparities in expenditures are evident. In 2003, the government will spend nearly $\$ 6,000$ for each Medicare recipient and more than $\$ 5,200$ on each veteran who uses services of the Veterans Administration. Federal prisoners and Medicaid patients will each receive more than twice the amount spent on Native American health care (see figure 3.2). In 2002, the Department of Defense spent $\$ 3,324$ per military member using its services. ${ }^{38}$ Even after adding IHS medical and nonmedical (such as community water and sewer) per person expenditures, IHS spends less on its service users than the government spends on any other group receiving public health care. This disparity in spending is amplified by the poorer health conditions of many in the Native American community and represents a direct affront to the legal and moral obligation the nation has to improve Indian health status. To correct this problem, the government must consider the data and determine, immediately and earnestly, what level of funding is needed to improve service delivery so that all eligible Native Americans receive adequate health care.

Some tentative strides have been made to establish the appropriate level of funding, however, the scope and resulting action associated with such efforts have been limited. For example, in recent years, the Federal Disparity Index Workgroup, sponsored by IHS, has measured gaps in health care funding to Indian people and made recommendations for distribution of the Indian Health Care Improvement Fund, which was established under the Indian Health Care Improvement Act. ${ }^{39}$ The act requires IHS to address deficiencies for tribes that have the highest health status and resource challenges. ${ }^{40}$

\footnotetext{
${ }^{35}$ Stephen Heffler et al., "Health Spending Projections for 2002-2012," Health Affairs, Feb. 7, 2003, p. W3-54.

${ }^{36}$ IHS, FY 2004 Budget Request, Justification of Estimates, p. 30.

${ }^{37}$ Nichols, "Indian Health Care."

38 Office of Management and Budget, FY 2004 Budget, Department of Defense, <http://www.whitehouse.gov/omb/ budget/fy2004/print/defense.html>.

${ }^{39}$ Indian Health Care Improvement Act of 1976, Pub. L. No. 94-437, 42 Stat. 1400 (codified as amended in scattered sections of 25 U.S.C.). The Indian Health Care Improvement Fund (IHCIF) was established in section 1621(a).

${ }^{40}$ Indian Health Care Improvement Act of 1976, Pub. L. No. 94-437, 42 Stat. 1400 (codified as amended in scattered sections of 25 U.S.C.). Although the IHCIF was established in 1992, no funds were appropriated until eight years later, in 2000. See also Crouch and Wiggins letter.
} 
FIGURE 3.2

Comparison Between IHS Appropriations Per Capita and Other Federal Health Expenditures, 2003

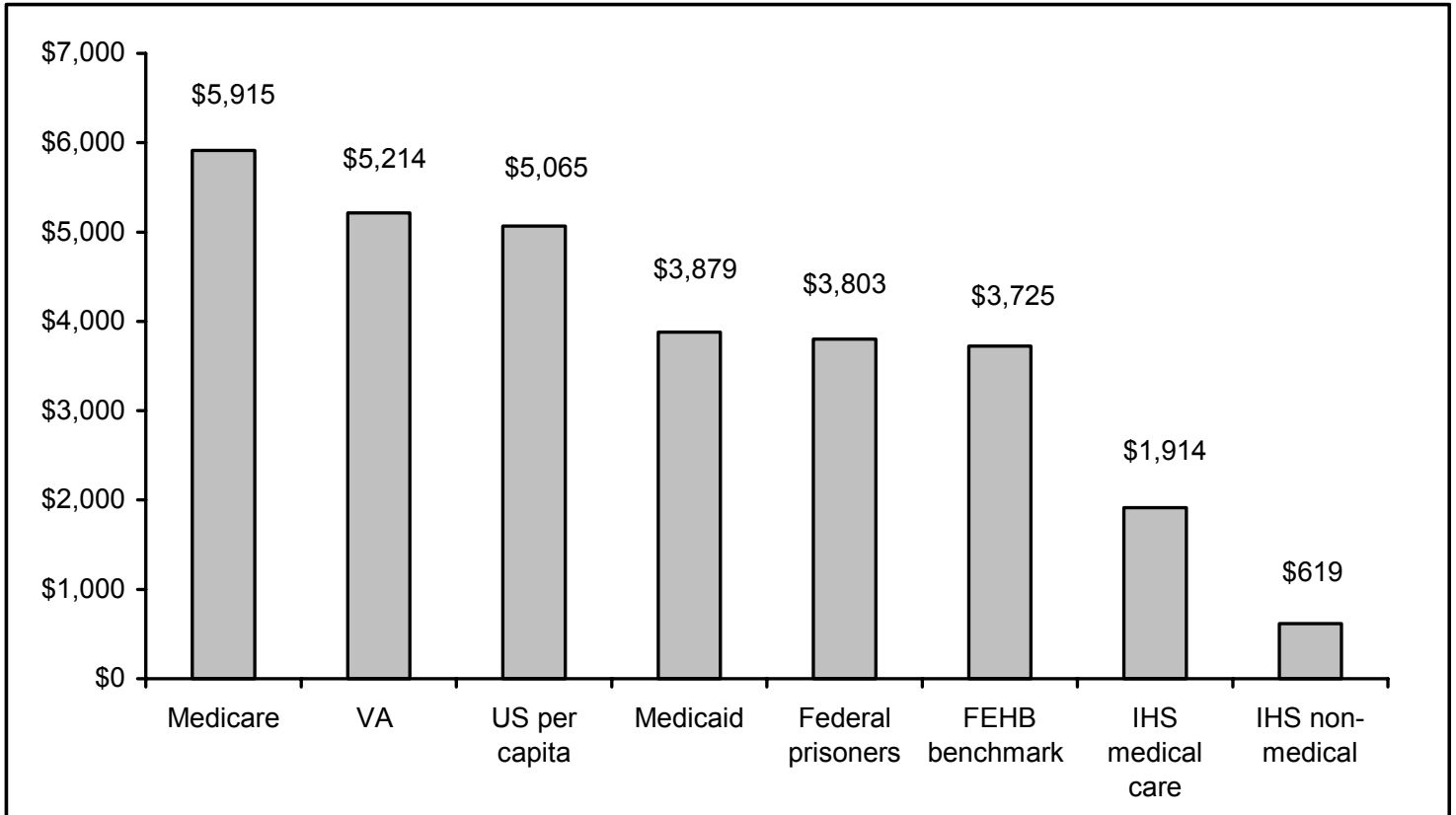

Note: The data in the chart represent forecasted expenditures for FY 2003 based on most recent available data for prior years. Source: U.S. Department of Health and Human Services, Indian Health Service, Office of Management Support, Division of Financial Management, "IHS Appropriations Per Capita Compared to Other Federal Health Expenditure Benchmarks, March 2003," submitted via facsimile, Mar. 27, 2003.

TABLE 3.7

IHS Health Care Expenditures vs. Mainstream Benefits Package Expenditures, 2001

Personal health care benefits package price benchmark

Cost to fully fund a benefits package for all IHS users

Price benchmark net of other coverage

Balance of cost to IHS

IHS expenditures for personal health care

IHS health care expenditures per user
$\$ 3,582$ per user annually

$\$ 4.96$ billion

$\$ 2,687$ per user annually

$\$ 3.72$ billion

$\$ 1.92$ billion

$\$ 1,384$

$52 \%$

Personal health care benefits as a percentage of benchmark

Source: James Allen Crouch and Cliff Wiggins, co-chairs, Federal Disparity Index Workgroup, letter to Dr. Michael Trujillo, director, Indian Health Service, Mar. 26, 2001, included in "FY 2001 FEHBP Disparity Index and Application of Findings to Allocate the FY 2002 Indian Health Care Improvement Fund," March 2002.

The workgroup compared IHS service costs with Federal Employees Health Benefit Program service costs. ${ }^{41}$ It found that a benefits package for IHS users comparable to that available to federal employees would have cost $\$ 3.72$ billion. $^{42}$ IHS actually spent $\$ 1.92$ billion that year on personal health care - $\$ 1,384$ per person-which is only 52 percent of the benchmark for health care costs net other sources of coverage (Medicare, private insurance, etc.).

\footnotetext{
${ }^{41}$ The formula took into account the price per user for a personal health care benefits package, inflation to account for the increase in cost for employer-sponsored health plans, and payments by other sources (such as Medicaid). The workgroup also calculated unmet needs based on health status factors.

${ }^{42}$ Crouch and Wiggins letter.
} 
In the context of overall spending shortfalls, there are specific areas in the IHS budget that lack the fiscal strength necessary to fulfill the Native American health care mandate. Following is a discussion of some of the areas that, based on this assessment, require increased budgetary commitment.

\section{Contract Health Services and Support Costs}

As noted above, Indian health systems are organized in two main structures: those managed by IHS and those managed by tribes. The shortfall of on-reservation facilities and the geographic vastness of Native American communities often necessitate that IHS contract with existing health care facilities for services beyond its reach. Even when tribes manage their own health care through selfdetermination contracts, the government nonetheless provides contract support funds for health professional training, staffing, and administration. Both of these systems-IHS contracting for external care and tribally provided care-require large sums of money.

The funding for contract health services is folded into the clinical services category in IHS' budget (see table 3.6). Roughly a quarter of the total amount budgeted for clinical services is dedicated to contracted care. It is estimated that $\$ 1$ billion is needed to meet the needs of the contract health service program in Indian Country. ${ }^{43}$ In 2002 , IHS received $\$ 460.8$ million for contract care, and in 2003 , it received $\$ 475$ million. ${ }^{44}$ IHS requests $\$ 493$ million in 2004 to run this program-less than half of the amount needed. Under current conditions, funds are only available to treat the most lifethreatening illnesses, leaving other potentially serious health needs unaddressed. Funds to contract care from specialists for health issues not served by IHS facilities, such as cardiologists or neurologists, are also insufficient.

Despite that many tribes have taken over health care, funding has not been enough to support the associated expenses, particularly for the many tribes already experiencing budget constraints. As a result, tribes have had to cut back on much-needed health services and use funds dedicated to other programs to cover insufficient contract support allocations. ${ }^{45}$ Total funding for contract support costs has remained roughly $\$ 270$ million in recent years (see table 3.6). It is estimated that an additional $\$ 150$ million is needed to meet the shortfall for existing contracts. As tribes increasingly take control of their own health programs, support costs will continue to increase. ${ }^{46}$

\section{Health Facilities}

As of 2001, there was a $\$ 900$ million backlog in unmet needs for health facilities, contributing to the inaccessibility of care and the degenerating health conditions of Native Americans. ${ }^{47}$ It is estimated that $\$ 1$ billion is needed for new construction of health facilities. ${ }^{48}$ It is further estimated that, at the current rate of funding, projects now on the IHS facilities construction priority list would be com-

\footnotetext{
${ }^{43}$ Davis-Wheeler testimony, p. 6.

${ }^{44}$ U.S. Department of Health and Human Services, Indian Health Service, Office of Management Support, Division of Financial Management, "Indian Health Service All Purpose Table," submitted via facsimile, Mar. 27, 2003.

${ }^{45}$ See U.S. General Accounting Office, "Indian Self-Determination Act: Shortfalls in Indian Contract Support Costs Need to Be Addressed," June 1999.

${ }^{46}$ Davis-Wheeler testimony, p. 7.

${ }^{47}$ Senator Ben Nighthorse Campbell, chair, and Senator Daniel K. Inouye, vice chair, Senate Committee on Indian Affairs, letter to the Senate Committee on the Budget, Mar. 1, 2002, as reported in Concurrent Resolution on the Budget, FY 2003, Report of the Committee on the Budget, United States Senate, Apr. 11, 2002, p. 122.

${ }^{48}$ Hall, "The State of Indian Nations Today."
} 
plete more than 30 years from now. ${ }^{49}$ The average age of IHS facilities is 32 years, making safety and efficiency a problem if not properly maintained. ${ }^{50}$ Likewise, aging medical equipment, which is used for twice the normal life span in Indian health care facilities compared with general facilities, is often rendered obsolete. ${ }^{51}$ Nonetheless, the FY 2004 budget request proposes an $\$ 11.7$ million decrease for the construction of health facilities over the 2003 appropriation. It also proposes a decrease for facility maintenance and improvement (\$2.2 million) and equipment (\$0.9 million). ${ }^{52}$

\section{Urban Health Programs}

The federal responsibility for Indian health care extends beyond the reservation and rural communities associated with Native populations to include those who live in urban and off-reservation areas. According to the 2000 census, nearly 60 percent of Native Americans live in urban areas, compared with 37.7 percent in $1990 .^{53}$ The growth of the urban Native American population is the result of numerous factors, including poor economic conditions on reservations that have forced members to relocate. It is precisely because of federal program failure on reservations that many Native Americans have fled to cities and towns in search of a better way of life, while at the same time trying to maintain cultural and historical ties. ${ }^{54}$

IHS funds 34 urban Indian health organizations at 41 sites; approximately 605,000 Native Americans are eligible to use these facilities. ${ }^{55}$ This year, urban Indian health programs received $\$ 31.3$ million, or 1.1 percent of the total IHS budget authority, and 1.3 percent of the amount spent on health services (see table 3.6). While the 2004 budget proposed a funding increase of $\$ 4.3$ million, urban program funding has not grown at nearly the rate at which the urban Indian population has grown.

According to the National Council of Urban Indian Health, the insufficient funding levels only enable IHS to serve roughly 96,000 of the 605,000 eligible urban Indians (about 16 percent). ${ }^{56}$ The organization estimates the unmet need for urban Indian health care at $\$ 1.5$ billion. It recommends a $\$ 6$ million increase to the President's 2004 budget proposal for urban health programs to enhance health services and offset inflation. ${ }^{57}$ While many valid reasons exist for health care spending to be concentrated in rural and reservation communities where infrastructure and other options are lacking, the needs of urban Indians are far from met. The prominent medical afflictions of urban and rural Native Americans are largely the same: alcohol and substance abuse, domestic and community violence, diabetes, cancer, mental illness, heart disease, poor dental health, and infectious disease.

\footnotetext{
49 Julia Davis-Wheeler, chair, National Indian Health Board, "Comments/Reaction to the 'State of American Indian Nations Address' by NCAI President Tex Hall," issue alert, Jan. 31, 2003, <www.nihb.org> (hereafter cited as DavisWheeler, "Comments/Reaction to the State of the American Indian Nations Address").

${ }^{50}$ IHS, FY 2004 Budget Request, Justification of Estimates, pp. IHS-17-18.

${ }^{51}$ Davis-Wheeler, "Comments/Reaction to the State of American Indian Nations Address."

${ }^{52}$ IHS, FY 2004 Budget Request, Justification of Estimates, pp. IHS-17-18.

${ }^{53}$ Ibid., p. 93. It is important to note that the 2000 census represented the first time individuals could indicate more than one race, complicating comparisons with previous census reports.

${ }^{54}$ Kay Culbertson, president, National Council of Urban Indian Health, testimony before the Senate Committee on Indian Affairs, Washington, D.C., Feb. 26, 2003, pp. 5-6 (hereafter cited as Culbertson testimony).

${ }^{55}$ IHS, FY 2004 Budget Request, Justification of Estimates, p. 94.

${ }^{56}$ Culbertson testimony, p. 7.

${ }^{57}$ Ibid., p. 8.
} 


\section{Special Diabetes Program}

Diabetes is disproportionately prevalent in American Indian/Alaska Native communities; Native American adults are more than three times as likely to have diabetes as the U.S. population in general. Native American children also experience higher, and growing, rates of diabetes. Amputation rates due to diabetes are three to four times higher among Native Americans than the general population. ${ }^{58}$ In 1997, a grant program, the Special Diabetes Program for Indians, was established for a term of five years. The program provides grants to tribes to engage in prevention, identification, and treatment of the disease. Initially, it was proposed as a \$30 million per year appropriation for diabetes prevention and treatment, but the budget authority for the program grew to $\$ 100$ million per year for fiscal years 2000-2003. The program was reauthorized in December 2002 at $\$ 150$ million per year for five years. ${ }^{59}$ A total of 318 grant recipients in 35 states currently receive funding under this program.

Although the Special Diabetes Program has made significant strides toward improving Native community health, the available funding (including the increase) is not enough to address the entire problem of diabetes among this vulnerable population. It is estimated that it costs between $\$ 5,000$ and $\$ 9,000$ per year to care for one diabetic person - a figure much higher than the average per person expenditure of IHS. The agency estimates that it would cost $\$ 425$ million per year to care for those who are currently diagnosed with the disease. ${ }^{60}$

\section{Health Care Professionals}

The current vacancy rate for IHS health professional positions is approximately 12 percent (ranging from 6 percent for sanitarians to 22 percent for dentists). ${ }^{61}$ The agency is also experiencing critical shortages of nurses, pharmacists, and optometrists, as well as health technicians. ${ }^{62}$ The Indian Health Care Improvement Act authorizes the training of Native Americans to enter health professions through scholarships, loan repayment programs, recruitment and retention, and employment placement. $^{63}$

Between 2002 and 2003, the agency actually saw a decrease in funding for health professional training. The administration's 2004 budget requests $\$ 35.4$ million for this purpose. The largest share, nearly half, is designated for the loan repayment program, followed by scholarships for health professional training. The 2004 request represents an increase of roughly $\$ 4.3$ million over the 2003 appropriation. ${ }^{64}$ However, the 2004 request does not adequately take into account the increasing cost of medical services, and will thus not enable IHS to fill vacancies for desperately needed health care professionals.

\footnotetext{
${ }^{58}$ FCNL, "Letter to Appropriations Interior Subcommittees."

${ }^{59}$ Act of Dec. 17, 2002, Pub. L. No. 107-360, 116 Stat. 3019 (codified as amended in 42 U.S.C.S. § 254c-3 (Law. Co-op. 2002)); IHS, FY 2004 Budget Request, Justification of Estimates, p. 127.

${ }^{60}$ IHS, FY 2004 Budget Request, Justification of Estimates, p. 131.

${ }^{61}$ IHS, "Fact Sheet."

${ }^{62}$ IHS, FY 2004 Budget Request, Justification of Estimates, p. IHS-99.

${ }^{63}$ The Indian Health Care Improvement Act of 1976, Pub. L. No. 94-437, 42 Stat. 1400 (codified as amended in scattered sections of 25 U.S.C.). Title I of the act, Indian Health Manpower, authorizes IHS funding for health professional training programs.

${ }^{64}$ IHS, FY 2004 Budget Request, Justification of Estimates, p. IHS-104.
} 


\section{Sanitation Services}

Another significant role of IHS is the construction and maintenance of sanitation facilities, including water supplies, sewage disposal, and solid waste sites, in individual homes and communities. Adequate sanitation facilities play a large role in disease prevention. Currently, however, approximately 21,500 Native American homes (nearly 8 percent) lack safe water. ${ }^{65}$ In comparison, the same is true for 1 percent of all U.S. homes. ${ }^{66}$

At the close of 2002, IHS estimated that it needed $\$ 900$ million to address all "economically feasible" projects. ${ }^{67}$ That year, $\$ 93.8$ million had been appropriated for sanitation facilities. More than half was used to address the backlog of existing homes needing service. For its 2003 budget, IHS received \$600,000 less than it had in 2002. The administration's FY 2004 request asks for \$114.2 million, an increase of \$21 million over the 2003 level, but still far short of the amount that would be necessary to meet the most critical sanitation needs (see table 3.6 above).

\section{Conclusion}

Whether failure to access health care is the result of its relative unavailability or its inadequacy, the end result is poor health for Native Americans. According to one health expert:

The greatest travesty in looking at the deplorable health of American Indians comes in recognizing that the vast majority of illnesses and deaths from disease could be preventable if funding [were] available to provide even a basic level of care. ${ }^{68}$

While this study demonstrates that funding for Native American health programs has increased in recent years, it must be considered in relation to the government's obligation and the population's needs. Against this measure, the Commission finds persistent inadequacy. Looking beyond budget numbers to what the numbers represent in purchasing power and unmet needs reveals a clearer picture:

- Between 1998 and 2003, HHS' budget for Native American programs increased 33 percent, slightly faster than the agency's overall budget. However, examination of the agency's discretionary budget, out of which Native American programs are funded, reveals a slower increase for Native American health than for other discretionary programs.

- Although IHS is the single largest funding source for Native American services, it receives only 0.5 percent of HHS' total budget authority and 4.4 percent of its discretionary budget, a smaller proportion today than in 1998.

- During the period reviewed, IHS' budget did not receive increases comparable to HHS as a whole, nor did its budget grow at the same rate as all Native American programs within the agency.

- In general, IHS budget increases have not kept pace with rising costs of health care or its growing service population. The agency currently operates with an estimated 59 percent of

\footnotetext{
${ }^{65}$ Ibid., p. IHS-14.

${ }^{66}$ U.S. Department of Health and Human Services, "President's 2004 Budget Will Propose Funding for Indian Health Service Sanitation Construction," press release, Jan. 17, 2003, <http://www.hhs.gov/news>.

${ }^{67}$ IHS, FY 2004 Budget Request, Justification of Estimates, p. IHS-14.

${ }^{68}$ Davis-Wheeler testimony, p. 2.
} 
what it needs to provide adequate health care. More is needed for, among other areas, contract care, urban health programs, health facility construction and renovation, and sanitation services.

The 2004 President's request represents an increase of $\$ 97$ million (or roughly 3 percent) over the 2003 program level. By calculation of the National Indian Health Board, a \$325 million increase in 2004 would be required to provide the same level of services, albeit inadequate services, as the current year. ${ }^{69}$ The 2004 proposed budget is thus insufficient to address the health needs of Native peoples.

It is estimated that IHS actually needs appropriations totaling roughly $\$ 18$ billion, including a onetime appropriation of $\$ 8$ billion for facility construction and $\$ 10$ billion per year for health care delivery for the next 10 years, if Native Americans are to begin to achieve health parity with other Americans. ${ }^{70}$ Never has actual funding for the agency come close to meeting that need, nor does it appear to be increasing in amounts that would fulfill that need in the immediate future. The anorexic budget of IHS can only lead one to deduce that less value is placed on Indian health than that of other populations. If funding levels continue to stagnate, the health status of Native Americans will continue to decline, resulting in even greater needs in the future. The solution is clear: a substantial and swift increase in funding commensurate with needs is the best preventive medicine the federal government can provide.

\footnotetext{
${ }^{69}$ Ibid., p. 4.

${ }^{70}$ Ibid., p. 5. Tex Hall, president, National Congress of American Indians, testimony before the Senate Committee on Indian Affairs, Feb. 26, 2003, p. 7.
} 


\section{Chapter 4: Department of Housing and Urban Development}

An important aspect of the federal government's legal and moral responsibility to Native Americans is its obligation to provide adequate housing. The U.S. Department of Housing and Urban Development (HUD) is responsible for ensuring the housing needs of Native Americans are met. Unfortunately, dismal housing conditions persist in Native communities, particularly among poverty-stricken and economically depressed reservations and villages.

According to members of the Senate Indian Affairs Committee, roughly 90,000 Indian families are homeless or under-housed; more than 30 percent of reservation households are crowded; 18 percent are severely crowded; and one in five Indian houses lacks complete plumbing facilities. ${ }^{1}$ Roughly 16 percent of Native American homes are without telephones, while only 6 percent of non-Native households lack telephone service. Some Native American communities lack even the infrastructure for telephone installation, hampering basic communication. ${ }^{2}$ Overall, approximately 40 percent of on-reservation housing is considered inadequate as compared with roughly 6 percent nationwide. ${ }^{3}$ For Native Hawaiians, the situation is even more dire: 36 percent of homes are overcrowded, and 49 percent of Native Hawaiians experience housing problems. ${ }^{4}$ Regional variations exist and are associated with geographic isolation, proximity to urban economies, and private ownership of land. For example, in Alaska, Arizona, and New Mexico, the rate of overcrowding and substandard housing is more than 60 percent.

Basic housing provisions that are taken for granted elsewhere in the nation are often absent on reservations. For example, fewer than 50 percent of homes on reservations are connected to a public sewer system. ${ }^{5}$ Twenty percent of homes must resort to other means of sewage disposal, often resulting in "honeybucket" methods in which household waste and sewage are collected into large receptacles that are later dumped into lagoons beyond the boundaries of the village or tribe. Settlements that use this system often suffer serious contamination and severe bacterial and viral infection from the waste and sewage washing back into the communities after heavy rainfall; this system also results in the poisoning of crops. ${ }^{6}$

\footnotetext{
${ }^{1}$ Senator Ben Nighthorse Campbell, chair, and Senator Daniel K. Inouye, vice chair, Senate Committee on Indian Affairs, letter to the Senate Committee on the Budget, Mar. 1, 2002, as reported in Concurrent Resolution on the Budget, FY 2003, Report of the Committee on the Budget, United States Senate, Apr. 11, 2002, p. 122 (hereafter cited as Senators Campbell and Inouye, letter to the Senate Committee on the Budget, Mar. 1, 2002).

${ }^{2}$ U.S. Department of Commerce, Economic Development Administration, “Assessment of Technology Infrastructure in Native Communities," < http://www.doc.gov/eda/html/reports_pubs.htm>.

${ }^{3}$ Eric Hensen, Jonathan B. Taylor, et al., Native America at the New Millennium (Cambridge, MA: Harvard University, John F. Kennedy School of Government, Project on American Indian Economic Development, November 2002), p. 139 (hereafter cited as Hensen and Taylor, Native America at the New Millennium).

${ }^{4}$ Senators Campbell and Inouye, letter to the Senate Committee on the Budget, Mar. 1, 2002, p. 135.

${ }^{5}$ Senator Ben Nighthorse Campbell, "Providing for Business Development and Trade Promotion for Native Americans, and For Other Purposes," S. REP. NO. 106-149, at 2 (1999).

${ }^{6}$ National American Indian Housing Council, Native American Housing News, special convention issue, June 2002 , p. 9.
} 
The need for subsidized housing appears to have grown at a rate inversely proportional to the availability of livable structures, and such housing is often not available in Indian Country. In 1998, Native American families waited nearly three and a half years for subsidized housing, twice as long as families nationally. ${ }^{7}$ High levels of unemployment and poverty on reservations render the need for subsidized housing more pressing. Housing problems are compounded by poor access to credit for home purchases, fractured land ownership, lack of infrastructure that supports housing communities, isolation and environmental conditions of reservations, and insufficient funds for housing programs. ${ }^{8}$

Dismal housing conditions have long plagued Indian Country, and the Commission has repeatedly documented the unmet housing needs of Native Americans. As early as 1961, in one of its first reports on Native Americans, the Commission reported, "As one might expect from the low economic status of Indians, the quality of reservation housing is far below the national average." 9 That seminal report also found that Native Americans suffered extensive denials and discrimination in housing akin to other minority groups in that era. In 1966, the Bureau of Indian Affairs estimated that 75 percent of houses on Indian reservations and in Alaska villages were substandard and overcrowded. More than two-thirds were too run down to even merit improvement. ${ }^{10}$ In 1972, a Commission hearing confirmed that substandard housing remained more often the case than not on Indian reservations. ${ }^{11}$

The need for homelands and housing predates modern history and goes back to the removal and allotment eras. At that time, hundreds of millions of acres of land were surrendered by tribes, and Native peoples were forced to relocate to unfamiliar and undeveloped regions where they had to struggle to even build traditional Native housing structures. It was not until the Snyder Act of 1921 that the Bureau of Indian Affairs (BIA) in the Department of the Interior was given the authority to provide housing assistance on reservations, ${ }^{12}$ although the federal government was not swift to address many housing needs. The Housing Act of 1937 established the nation's intention to eliminate unsanitary and unsafe housing conditions for poor American families. ${ }^{13}$ However, again the needs of Native Americans were largely ignored, as the act was not initially interpreted to include them. The omission of Native Americans from the act reflected a post-World War II shift in federal policy away from self-determination and toward decreasing the federal trust responsibility. ${ }^{14}$ It was not until 1961 that the federal government began to substantially address the housing needs of non-urban Indians by redirecting the Housing Act to include Indian reservations. Thus, it took the federal government nearly 30 years to recognize the need for housing assistance on Native American lands despite longdocumented evidence of treacherous living conditions. ${ }^{15}$

\footnotetext{
${ }^{7}$ Friends Committee on National Legislation, "Housing Native Youth: Shortages and Struggles," Feb. 28, 2001, <http://www. fcnl.org/issues/nat/sup/indians_housing.htm>.

${ }^{8}$ Ibid.

${ }^{9}$ U.S. Commission on Civil Rights, Justice, 1961, p. 151.

${ }^{10}$ U.S. Commission on Civil Rights, Federal Policies and Programs for American Indians, staff report, Albuquerque/Phoenix hearings, November 1972, p. 46.

11 Ibid.

${ }^{12}$ Snyder Act of 1921, ch. 115, 42 Stat. 208 (codified as amended at 25 U.S.C. $\S 13$ (1994)).

${ }^{13}$ The United States Housing Act of 1937, Pub. L. No. 75-412, 50 Stat. 888 (codified as amended at 42 U.S.C. § 1437 (1994)). The act resulted in the Public Housing Program, which was to provide livable, safe, and sanitary housing entities for low-income families.

${ }^{14}$ Susan J. Ferrell, “Indian Housing: The Fourth Decade,” St. Thomas Law Review, vol. 7 (summer 1995), p. 452 (hereafter cited as Ferrell, "Indian Housing").

${ }^{15}$ Ferrell, "Indian Housing,” p. 451.
} 
In the early 1960s, BIA developed a housing improvement program based on a 1961 departmental task force, which reported a compelling need for Native American housing. An agency then known as the Public Housing Administration (PHA) also made it possible for tribes to establish Indian Housing Authorities to apply for and receive federal housing funds. Together, PHA and BIA developed the Mutual Help Home Ownership Opportunity Program, designed to enable Native Americans to move from leasing to owning single-family homes through payments based on income level. ${ }^{16}$ While the intent of the program was honorable, the cost of monthly payments, utilities, and home maintenance was often prohibitive, particularly with poor reservation economies.

In 1965, HUD was created in an effort to consolidate various housing programs that existed across federal agencies, including those that served Native Americans. Through the 1970s many reservation housing programs faced serious financial and administrative problems, and the task of eliminating housing disparities in Indian Country was determined greater than anticipated. ${ }^{17}$ In 1988 , HUD created a separate Native American housing program and the Office of Native American Programs, with the passage of the Indian Housing Act. ${ }^{18}$ Today, nearly all housing in Native American communities is provided through federal programs, most commonly through HUD funding. ${ }^{19}$ HUD assistance consists of funds for housing construction, funds for maintenance of low-income rental units, and loan guarantee assistance for homeownership. The federal government has struggled to improve living conditions on reservations for decades, and these attempts have not been entirely successful.

Unlike other agencies, such as the Indian Health Service, HUD's programs for Native Americans are not directly service driven, but rather provide support through grants to tribes and tribal housing authorities. As this chapter will show, HUD's grant programs have not consistently received the appropriations necessary to address the extensive housing needs of this population.

\section{The Native American Housing Assistance and Self-Determination Act}

The Native American population faces circumstances, and hence needs, that differ from the general population. The dismal housing situation is compounded by the difficulties many Native Americans face in accessing credit and loans, due in part to their unique relationship with the federal government and the fact that they do not own land titles. Fewer than 33 percent of Native Americans own their own homes, compared with 67 percent of all Americans. ${ }^{20}$ In 1996, the government attempted to address these unique concerns, as well as housing conditions, with the passage of the Native American Housing Assistance and Self-Determination Act (NAHASDA). ${ }^{21}$

\footnotetext{
${ }^{16}$ Ibid., pp. 453-54.

${ }^{17}$ National American Indian Housing Council, Too Few Rooms: Residential Crowding in Native American Communities and Alaska Native Villages, 2001, p. 9 (hereafter cited as NAIHC, Too Few Rooms).

${ }^{18}$ Indian Housing Act, Pub. L. No. 100-358, 102 Stat. 676 (codified as 42 U.S.C. $§ 1437$ aa, repealed 1996). See also Coalition for Indian Housing and Development, submission to the Millennial Housing Commission, June 29, 2001 , p. 2 (hereafter cited as Coalition for Indian Housing and Development, submission).

${ }^{19}$ Coalition for Indian Housing and Development, submission. Other agencies that play a role in Native American housing are the Bureau of Indian Affairs, the Indian Health Service, the Department of Agriculture, and the Department of Veterans Affairs.

${ }^{20}$ U.S. General Accounting Office, "Native American Housing: VA Could Address Some Barriers to Participation in Direct Loan Program,” August 2002, p. 1.

${ }^{21}$ Native American Housing Assistance and Self-Determination Act of 1996, Pub. L. No. 104-330, 110 Stat. 4016 (codified as amended at 25 U.S.C. $\S \S 4101-4195$ (Supp. IV 1998)).
} 
Before NAHASDA's implementation in 1998, HUD provided federal housing assistance to Native Americans through virtually the same public housing programs that were provided to the rest of the nation's low-income families. Through HUD's headquarters, six field offices, and 217 Native American housing authorities, the department provided funding to Native American communities for the construction, maintenance, and rehabilitation of low-income housing. ${ }^{22}$ HUD directed 14 programs for the distribution of funding to Native American housing authorities and tribes; nine awarded the funding competitively. The remaining five programs granted funding through HUD's noncompetitive method, which used specific formulas or distributed the funds on a first-come, firstserved basis. Between fiscal years 1993 and 1997, HUD's 14 programs distributed \$2.8 billion to Native American housing authorities and tribes. ${ }^{23}$

NAHASDA separated Native American housing from general public housing, both administratively and financially. The act, recognizing tribal rights to self-governance and self-determination, was designed to permit tribal recipients to manage and monitor housing assistance programs. It is structured to provide flexibility in tribal planning, implementation, and administration of housing programs.

NAHASDA eliminated nine of the 14 separate Native American housing assistance programs and replaced them with a single block grant. ${ }^{24}$ Grants are now available to approximately 575 Native American housing entities based on a noncompetitive allocation formula that considers population, housing need, and current assisted stock. The current assisted stock (the housing units developed prior to NAHASDA as a result of the 1937 Housing Act) component consists of two elements: an operating subsidy and a modernization allocation. Need is determined by seven weighted criteria, including such factors as population, overcrowding, extent of poverty, and burden of household's housing costs. ${ }^{25}$ While the block grant is allocated to tribes, many tribes select a tribally designated housing entity (TDHE) to be the actual recipient of funds. In some cases, different tribes appoint the same TDHE to receive funds and administer housing programs. In 2002, for example, there were 363 grant recipients representing 542 tribes. $^{26}$

HUD has authority to monitor expenditures of NAHASDA block grants and require recipients to submit quarterly expenditure reports. Tribes or TDHEs submit to HUD an Indian Housing Plan each year, which must be found in compliance with the act, to receive funding. They also submit an Annual Performance Report. ${ }^{27}$ If through site visits or reviewing tribal reports, the department discovers that housing units fail to comply with the regulations of NAHASDA, it can reduce or terminate future grant requests and/or provide replacements for the housing entities managing the programs. The new single block grant formula that was established under NAHASDA did not factor in Native American housing program funding awarded in previous years and left unspent, although tribes had

\footnotetext{
${ }^{22}$ U.S. General Accounting Office, "Native American Housing: Information on HUD's Funding of Indian Housing Programs," November 1998 (hereafter cited as GAO, "Information on HUD’s Funding of Indian Housing Programs").

${ }^{23}$ GAO, "Information on HUD’s Funding of Indian Housing Programs," p. 2.

${ }^{24}$ NAHASDA did not alter the following five programs: Indian Community Block Grants, Drug Elimination Grants, Drug Elimination Technical Assistance Grants, Economic Development and Supportive Services, and Section 184 Indian Home Loan Guarantees.

${ }^{25}$ U.S. Department of Housing and Urban Development, Office of Native American Programs, facsimile to U.S. Commission on Civil Rights, July 18, 2003, re: affected agency review comments.

${ }^{26}$ Ibid.

${ }^{27}$ U.S. Department of Housing and Urban Development, Homes and Communities, <http://www.hud.gov:80/office/pih/ ih/grants/ihbg.cfm>.
} 
to report their planned use of those funds upon implementation of the act. ${ }^{28}$ It is ultimately the tribe's responsibility to make certain that grant funds are allocated efficiently and appropriately.

\section{HUD Funding of Native American Programs}

Tribes' housing needs remain disproportionately high compared with their housing block grant. As a result, tribal housing entities are only able to maintain their housing status quo and have had difficulty making headway to addressing their members' overall needs. ${ }^{29}$

As of April 2002, the construction or renovation of approximately 25,000 homes had been facilitated by NAHASDA. ${ }^{30}$ Although estimates of required Native American housing units vary, studies approximate an immediate need that is close to $200,000 .{ }^{31}$ This number may be an underestimation of the actual need for housing because it is calculated based on waiting lists, and does not take into consideration the needs of tribal members and families moving back to reservations because public assistance has expired or other economic factors prohibit living off-reservation. ${ }^{32}$ HUD itself estimates that current NAHASDA funding will only meet 5 percent of the need for housing and that more than 230,000 housing units are still needed for Native American families. ${ }^{33}$ In addition, there are approximately 20,000 families on a waiting list for space on Hawaiian homelands, some of whom have been waiting 20 years. ${ }^{34}$ The level of need far exceeds the amount of funding. As a result, tribal housing entities are only able to maintain the status quo, and cannot offer significant improvement to overall living conditions.

Placed in context of HUD's overall budget authority, the housing needs of Native Americans are disproportionately underfunded. In the current fiscal year (2003), HUD received a budget of nearly \$34 billion; \$30.4 billion is for its discretionary programs, out of which Native American grants are allocated. Yet, in total, Native American programs received roughly $\$ 731$ million or 2.4 percent of the discretionary budget (table 4.1 and 4.2).

\footnotetext{
${ }^{28}$ GAO, “Information on HUD’s Funding of Indian Housing Programs," pp. 2-3.

${ }^{29}$ Senators Campbell and Inouye, letter to the Senate Committee on the Budget, Mar. 1, 2002, p. 135.

${ }^{30}$ Roberta Youmans, Federal Housing Finance Board, "Native American Housing Needs and Proposed Recommendations," background paper presented to the Millennial Housing Commission, Apr. 2, 2002, p. 5 (hereafter cited as Youmans, "Native American Housing Needs").

${ }^{31}$ Youmans, "Native American Housing Needs," p. 4.

32 Ibid.

${ }^{33}$ U.S. Department of Housing and Urban Development and U.S. Department of the Treasury, One-Stop Mortgage Center Initiative in Indian Country: A Report to the President, October 2000.

${ }^{34}$ Youmans, "Native American Housing Needs," p. 9.
} 
TABLE 4.1

HUD Budget Authority, Discretionary Budget, and Native American Program Funding, FY 1998-2004

(in millions of dollars)

\begin{tabular}{lrrrrrrr}
\hline & $\mathbf{1 9 9 8}$ & $\mathbf{1 9 9 9}$ & $\mathbf{2 0 0 0}$ & $\mathbf{2 0 0 1}$ & $\mathbf{2 0 0 2}$ & $\mathbf{2 0 0 3}$ & $\mathbf{2 0 0 4}$ \\
\cline { 2 - 7 } Budget Authority & 21,022 & 26,344 & 24,324 & 32,370 & 35,578 & 33,966 & 34,981 \\
Percent change from previous year & & $25.3 \%$ & $(7.7 \%)$ & $33.1 \%$ & $9.9 \%$ & $(4.5 \%)$ & $1.5 \%$ \\
Constant 2003 dollars** & 23,182 & 28,594 & 25,738 & 33,499 & 36,256 & 33,966 & 34,339 \\
\hline Discretionary Authority & 19,744 & 22,163 & 21,111 & 28,357 & 31,428 & 30,400 & 31,301 \\
Percent change from previous year & & $12.3 \%$ & $(4.8 \%)$ & $34.3 \%$ & $10.8 \%$ & $(3.3 \%)$ & $1.3 \%$ \\
Constant 2003 dollars & 21,773 & 24,056 & 22,338 & 29,346 & 32,026 & 30,400 & 30,727 \\
Native American Programs & 672.0 & 693.6 & 693.0 & 725.4 & 735.2 & 731.2 & 731.1 \\
Percent change from previous yearyyyyyyyyyyyyyyyy & & $3.1 \%$ & $(0.1 \%)$ & $4.7 \%$ & $1.4 \%$ & $(0.5 \%)$ & 0 \\
Constant 2003 dollars & 741.0 & 752.2 & 733.3 & 750.9 & 749.6 & 731.2 & 717.7 \\
\hline
\end{tabular}

* Estimate based on 2004 budget request.

** To adjust for inflation, the composite deflators used by the Office of Management and Budget and provided in the 2004 Budget of the United States were used.

Sources: Office of Management and Budget, Budget of the United States, Fiscal Year 2004, tables 5.2 and 5.4, pp. 95-96, 103-04; U.S. Department of Housing and Urban Development, Office of Budget, "Indian and Hawaiian Appropriation and Disbursements, 1998 through 2003," submitted via facsimile, Apr. 17, 2003.

During the six-year period under review, HUD's total budget authority increased approximately 62 percent. The agency's discretionary authority increased 54 percent. At the same time, Native American program funding only increased 8.8 percent. After adjusting for inflation, the agency's budget authority actually increased 46.5 percent; discretionary funds increased 39.6 percent; and Native American funding decreased 1.3 percent. As table 4.2 illustrates, the proportion of HUD's budget dedicated to Native American programs has declined in recent years, from 3.2 percent in 1998 to 2.2 percent in 2003.

TABLE 4.2

Native American Programs as a Percentage of HUD Appropriations, FY 1998-2004

\begin{tabular}{|c|c|c|c|c|c|c|c|}
\hline & 1998 & 1999 & 2000 & 2001 & 2002 & 2003 & 2004 \\
\hline $\begin{array}{l}\text { Native American programs } \\
\text { (in millions of dollars) }\end{array}$ & 672.0 & 693.6 & 693.0 & 725.4 & 735.2 & 731.2 & 731.1 \\
\hline Percent of total budget authority & $3.2 \%$ & $2.6 \%$ & $2.8 \%$ & $2.2 \%$ & $2.1 \%$ & $2.2 \%$ & $2.1 \%$ \\
\hline Percent of discretionary authority & $3.4 \%$ & $3.1 \%$ & $3.3 \%$ & $2.6 \%$ & $2.3 \%$ & $2.4 \%$ & $2.3 \%$ \\
\hline
\end{tabular}

Sources: Office of Management and Budget, Budget of the United States, Fiscal Year 2004, tables 5.2 and 5.4, pp. 95-96, 103-04; U.S. Department of Housing and Urban Development, Office of Budget, "Indian and Hawaiian Appropriation and Disbursements, 1998 through 2003," submitted via facsimile, Apr. 17, 2003.

As indicated earlier, NAHASDA consolidated many of HUD's earlier Native American programs. Today, the agency houses three primary programs to support housing construction and promote homeownership in Native American communities. They are the Native American Housing Block Grant; the Indian Home Loan Guarantee Program (also known as the Section 184 Home Guarantee Program); and the Indian Community Development Block Grant. These programs are administered by HUD's Office of Native American Programs within the Office of Public and Indian Housing.

In addition to these, HUD has established two programs to improve the housing conditions of Native Hawaiians, even though they are not recognized as having the same special government status as Native Americans. The Native Hawaiian Housing Block Grant, which is modeled after the Native American Housing Block Grant, recognizes the housing needs of Hawaiians who live on designated 
Hawaiian homelands and provides funds for the purchase, construction, and rehabilitation of housing. ${ }^{35}$ The second program is the Hawaiian Home Loan Guarantee Fund, which is modeled after the Indian Home Loan Guarantee program. ${ }^{36}$ Its purpose is to increase homeownership among Native Hawaiians by providing loan guarantees and to enable the financing of mortgages by private lenders that would not otherwise be possible due to the unique legal status of Hawaiian Homelands. ${ }^{37}$ These programs are not assessed in this study because they are not within its scope; they are noteworthy, however, because HUD includes them when calculating funding totals for Native American programs.

Likewise, because this report focuses on those programs specifically designated for Native Americans, it does not include general population housing programs from which Native peoples benefit. For example, the Rural Housing and Economic Development Grant and Federal Housing Administration Mortgage Insurance Programs have provided funding for Indian community and housing development.

\section{TABLE 4.3}

HUD Budget Authority for Native American Programs, FY 1998-2004 (in millions of dollars)

\begin{tabular}{lrrrrrrr}
\hline & $\mathbf{1 9 9 8}$ & $\mathbf{1 9 9 9}$ & $\mathbf{2 0 0 0}$ & $\mathbf{2 0 0 1}$ & $\mathbf{2 0 0 2}$ & $\mathbf{2 0 0 3}$ & $\mathbf{2 0 0 4}^{*}$ \\
\cline { 2 - 7 } Native American Housing Block Grant & 600.0 & 620.2 & 620.0 & 648.6 & 648.6 & 644.8 & 646.6 \\
NAHASDA Loan Guarantee Program ** & 5.0 & 6.0 & 6.0 & 6.0 & 6.0 & 2.0 & 1.0 \\
Section 184 Loan Guarantee Program & 5.0 & 6.4 & 6.0 & 6.0 & 6.0 & 5.3 & 1.0 \\
Indian Community Development Block Grant & 67.0 & 67.0 & 67.0 & 70.8 & 70.0 & 70.5 & 72.5 \\
Native Hawaiian Block Grant & -- & -- & -- & -- & 9.6 & 9.5 & 10.0 \\
Native Hawaiian Loan Guarantee Program & -- & -- & -- & -- & 1.0 & 1.0 & 1.0 \\
\cline { 2 - 7 } Total & $\mathbf{6 7 2 . 0}$ & $\mathbf{6 9 3 . 6}$ & $\mathbf{6 9 3 . 0}$ & $\mathbf{7 2 5 . 4}$ & $\mathbf{7 3 5 . 2}$ & $\mathbf{7 3 1 . 1}$ & $\mathbf{7 3 1 . 1}$ \\
Constant 2003 dollars & $\mathbf{7 4 1 . 0}$ & $\mathbf{7 5 2 . 8}$ & $\mathbf{7 3 3 . 3}$ & $\mathbf{7 5 0 . 7}$ & $\mathbf{7 4 9 . 2}$ & $\mathbf{7 3 1 . 1}$ & $\mathbf{7 1 7 . 7}$ \\
\hline Nyyyyyyy
\end{tabular}

Note: Includes rescissions of 0.22 percent for 2001 and 0.65 percent for 2003; numbers are rounded.

* Estimate based on 2004 budget request.

** Set-aside that comes out of the total Indian housing block grant. Although it is reported separately in appropriations, it is not included in the totals to avoid duplication.

Sources: U.S. Department of Housing and Urban Development, Office of Budget, "Indian and Hawaiian Appropriation and Disbursements, 1998 through 2003," submitted via facsimile, Apr. 17, 2003; U.S. Department of Housing and Urban Development, Fiscal Year 2004 Budget Summary, appendix B, <http://www.hud.gov/about/budget/fy04/appendixb.pdf>.

Overall, between 1998 and 2003, the amount of funding for HUD's Native American grant programs did not increase significantly and, in fact, lost purchasing power. In 1998, the agency received $\$ 672$ million; in 1999 the amount increased to $\$ 693.6$ million. The largest increase occurred between 2000 and 2001, when the agency received an increase of $\$ 32.4$ million. In 2002, the amount of funding for the existing block grants remained roughly the same, but the new $\$ 10$ million Native Hawaiian Block Grant Program was added. Fiscal year 2003 saw a decrease in funding by $\$ 4$ million (table 4.3). As noted above, the actual purchasing power of the Native American block grants is significantly less in 2003 than it was in 1998 and has been on the decline since 2001 (see table 4.1).

Because HUD's Native American funding is in the form of grant programs, the amount distributed each year depends on a number of factors, such as the number of applicants, amount requested, and number of awards granted. Although HUD received appropriations to fund $\$ 3.52$ billion in grants

\footnotetext{
${ }^{35}$ HUD, FY 2004 Budget Summary, p. 17.

${ }^{36}$ See Hawaiian Homelands Homeownership Act of 2000, Pub. L. No. 106-568, 114 Stat. 2872 (2000). See also HUD, FY 2004 Budget Summary, pp. 16-17.

${ }^{37}$ U.S. Department of Housing and Urban Development, Office of Public and Indian Housing, "Native Hawaiian Loan Guarantee Fund," FY 2004 Budget Proposal, p. H-15.
} 
between 1998 and 2002, the amount actually disbursed was $\$ 3.37$ billion (see table 4.4). ${ }^{38}$ Each year there have been allocated funds that have not been distributed to eligible tribes, for example, because a tribe did not submit an Indian Housing Plan or the plan was found not in compliance. Leftover funds are carried over and later distributed to eligible recipients (see figure 4.1). During the five-year period, approximately $\$ 151$ million was not distributed, some of which may still be pending disbursement.

TABLE 4.4

Actual Disbursements of Native American/Native Hawaiian Grant Funds, FY 1998-2002 (in millions of dollars)

\begin{tabular}{|c|c|c|c|c|c|}
\hline & 1998 & 1999 & 2000 & 2001 & 2002 \\
\hline Native American Housing Block Grant & 452.9 & 596.9 & 643.5 & 684.0 & 713.1 \\
\hline Section 184 Loan Guarantee Program & 2.0 & 1.8 & 1.6 & 1.0 & 0.8 \\
\hline Indian Community Development Block Grant & 45.4 & 52.5 & 49.8 & 58.2 & 64.3 \\
\hline Native Hawaiian Block Grant & -- & -- & -- & -- & -- \\
\hline Native Hawaiian Loan Guarantee Program & -- & -- & -- & -- & 0.035 \\
\hline Total & 500.3 & 651.2 & 694.9 & 743.2 & 778.3 \\
\hline
\end{tabular}

Note: Because this report was drafted midyear 2003, actual disbursements for 2003 were not yet available; numbers are rounded.

Source: U.S. Department of Housing and Urban Development, Office of Budget, "Indian and Hawaiian Appropriation and Disbursements, 1998 through 2003," submitted via facsimile, Apr. 17, 2003.

FIGURE 4.1

Comparison of Native American Appropriations and Disbursements, FY 1998-2002

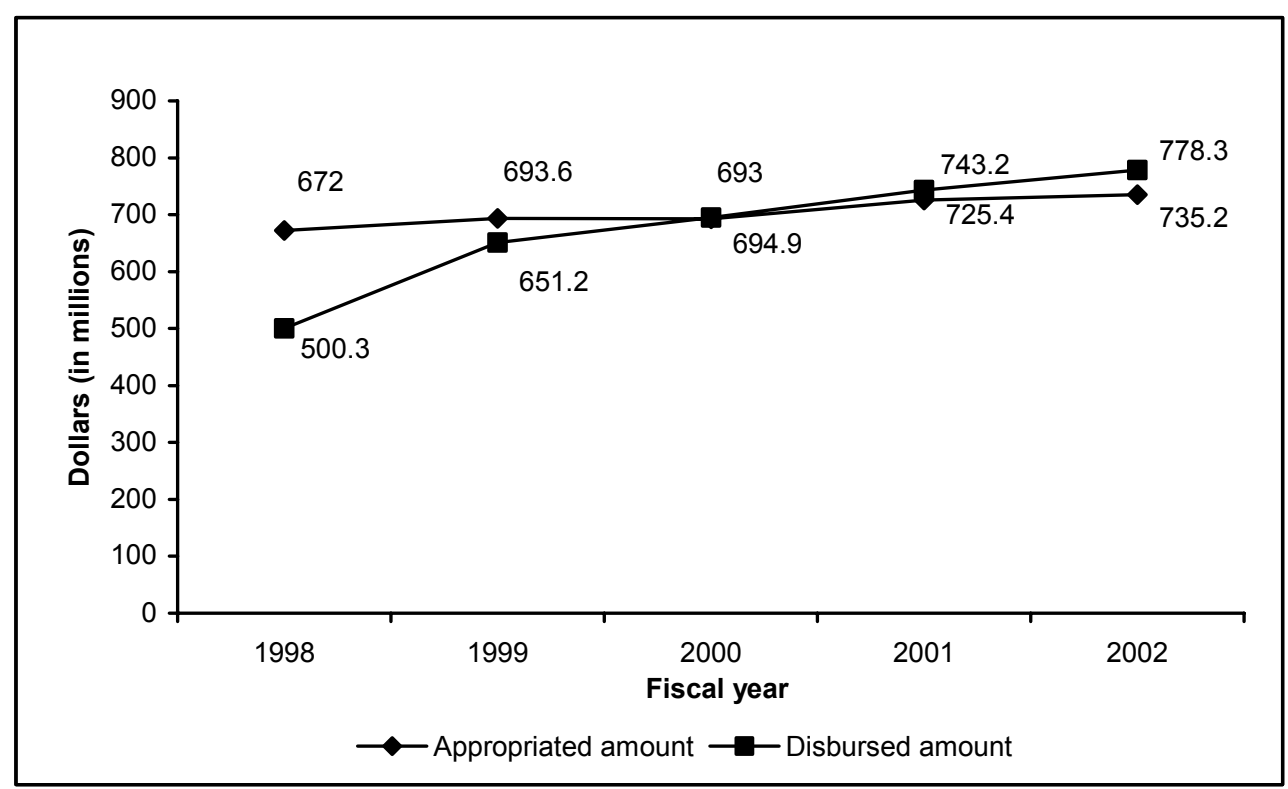

Source: U.S. Department of Housing and Urban Development, Office of Budget, "Indian and Hawaiian Appropriation and Disbursements, 1998 through 2003," submitted via facsimile, Apr. 17, 2003.

\footnotetext{
${ }^{38}$ At the time this report was drafted, fiscal year 2003 disbursements had not yet been finalized.
} 


\section{Native American Housing Block Grant}

The Native American Housing Block Grant (NAHBG) ${ }^{39}$ program gains its statutory authority directly from NAHASDA, which authorized direct block grants to tribal governments or tribally designated entities. Grants are awarded on a formula basis that was established in agreement with tribes. Funds can be used to develop new housing to meet shortages or to maintain existing units. Grants may also be used to provide housing services, administer units, or engage in crime prevention. ${ }^{40}$ HUD uses a formula for calculating how much to award tribes, taking into account current assisted stock and need, as noted above.

At roughly $\$ 645$ million annually, this is the largest direct source of federal funding for Native American housing. In 2003, HUD received \$644.8 million, an amount \$3.8 million less than it had received in each of the preceding two years. The NAHBG has lost spending value for three years in a row, a trend continued with the 2004 budget request.

Considering that these limited funds are available to 575 housing entities, this is not a significant amount of money. If the money were distributed evenly among all potentially eligible tribes, each would receive approximately $\$ 1.1$ million. But, of course, not all tribes have the same needs. For example, some larger tribes with expansive land bases find it critical to build infrastructure such as sewage and water systems, adequate roads, and electricity before they can build homes. Small tribes sometimes need to spend money on basic training to learn how to operate housing programs effectively. ${ }^{41}$

Further, only about 40 percent of funding actually goes toward new construction. The remaining 60 percent of the appropriation is spent on operating subsidies. ${ }^{42}$ Funds are used for administrative costs, staff expenses, travel, and training. ${ }^{43}$ The Coalition for Indian Housing and Development estimates that at least $\$ 1.1$ billion is needed annually to adequately fund the block grant, allowing $\$ 600$ million for new construction. ${ }^{44}$ The National American Indian Housing Council estimates the same need, citing increased housing costs in a booming real estate market and inflation. To maintain the same purchasing power as 2001, the 2004 appropriation would have to be $\$ 700$ million. $^{45}$

\section{Title VI Tribal Housing Activities Loan Guarantee Program}

The Native American Housing Block Grant includes a mandated set-aside for tribal housing guarantees. The purpose of the set-aside is to provide guaranteed loans to NAHBG recipients who need funds to foster affordable housing initiatives but cannot borrow from private sources without guarantee of

\footnotetext{
${ }^{39}$ Some sources refer to this as the Indian Housing Block Grant Program.

${ }^{40}$ U.S. Department of Housing and Urban Development, Fiscal Year 2004 Budget Summary, p. 16 (hereafter cited as HUD, FY 2004 Budget Summary).

${ }^{41}$ Russell Sossamon, "Tribes Need More Funds, More Attention for Housing," Indian Country Today, Aug. 22, 2002, $<$ http://www.IndianCountry.com/?1029957358> (hereafter cited as Sossamon, "Tribes Need More Funds").

${ }^{42}$ Coalition for Indian Housing and Development, submission, p. 8.

${ }^{43}$ Sossamon, "Tribes Need More Funds."

${ }^{44}$ Coalition for Indian Housing and Development, submission, p. 8.

${ }^{45}$ Russell Sossamon, chair, National Indian Housing Council, testimony before the Senate Committee on Indian Affairs, Feb. 26, 2003 (hereafter cited as Sossamon testimony).
} 
payment by the federal government. ${ }^{46}$ The program can be used to guarantee loans for Indian housing assistance, housing development, housing management, crime prevention, and model activities.

This relatively small fund held steady at $\$ 6$ million for several years (from 1999 through 2002) but was slashed by two-thirds to $\$ 2$ million between fiscal years 2002 and 2003 . After adjusting for inflation, the program actually lost nearly 70 percent of its purchasing power between its highest level in 1999 and 2003. The 2004 budget request would again cut the fund in half to \$1 million, essentially reducing the loan amount supported from $\$ 16.6$ million to $\$ 8$ million.

\section{Indian Home Loan Guarantee Program (Section 184)}

A third program designed to help Native Americans access private mortgage financing for the purchase, construction, or maintenance of single-family homes is the Indian Home Loan Guarantee program. Commonly referred to as the Section 184 loan guarantee program, it was instituted under the Housing and Community Development Act of $1992 .{ }^{47}$ It authorizes HUD to guarantee loans from private lenders to Native American families, tribes, and housing authorities. ${ }^{48}$ Basically, if a mortgage holder (a Native American family or individual) defaults on a loan, HUD pays the balance and assumes property ownership from the lender. ${ }^{49}$

This program has received fairly consistent funding since 1998, receiving $\$ 5$ million that year and roughly $\$ 6$ million for each subsequent year until 2003, when it received funding at $\$ 5.3$ million. Despite its moderate budget, according to the Housing Assistance Council, Section 184 is the most widely used financial product to encourage private lending on restricted land. ${ }^{50}$ HUD documents show that as of February 28, 2003, the program had guaranteed 1,204 loans totaling more than $\$ 115$ million. The largest share was in the state of Alaska; there, 309 loans have been guaranteed for a total of more than $\$ 47.7$ million. ${ }^{51}$ While it should be noted that the usefulness of this program is limited to those Native Americans who can afford to purchase a home and that it does not directly benefit many low-income Native Americans families, it is the major source of mortgage financing for moderate income families living on tribal lands.

The President's 2004 budget proposal would reduce Section 184 funding to $\$ 1$ million. ${ }^{52}$ It appears that this decrease will be divided among other Native American program areas to maintain overall level funding for 2004 (see table 4.3). It is estimated that the reduced loan guarantee program will support \$27 million in loans, significantly less than the anticipated \$200 million worth of loans that will be supported in fiscal year 2003. ${ }^{53}$

\footnotetext{
${ }^{46}$ HUD, FY 2004 Budget Summary, p. 16; see also U.S. Department of Housing and Urban Development, Homes and Communities, <http://www.hud.gov:80/offices/pih/ih/homeownership/titlevi/index.cfm>.

${ }^{47}$ Housing and Community Development Act of 1992, Pub. L. No. 102-550, 106 Stat. 3739 (codified as amended at 12 U.S.C. § 1715z-13a (Supp. IV 1998)). Section 184 of the act was established in 1994.

${ }^{48}$ Housing Assistance Council, Taking Stock: Rural People, Poverty, and Housing at the Turn of the 21st Century, 2002, p. 101 (hereafter cited as HAC, Taking Stock).

${ }^{49}$ Ferrell, "Indian Housing," p. 459.

${ }^{50}$ HAC, Taking Stock, p. 101.

${ }^{51}$ U.S. Department of Housing and Urban Development, Homes and Communities, "About the Indian Home Loan Guarantee Program," <http://www.hud.gov:80/offices/pih/ih/homeownership/184/about.cfm>.

${ }^{52}$ HUD, FY 2004 Budget Summary, p. 16.

${ }^{53}$ Housing Assistance Council, Something Old, Something New: An Analysis of the Administration's Proposed Fiscal Year 2004 Rural Housing Budget, March 2003, pp. 25-26.
} 


\section{Indian Community Development Block Grant Program}

At $\$ 4.9$ billion (in 2003), the Community Development Block Grant (CDBG) is one of the largest grants HUD administers. A portion of the grant is set aside specifically for Native Americans. The actual appropriation of grants to tribes varies from year to year, but statutorily, a minimum of 1 percent of the total block grant is reserved for Indian Country. The 2003 Native American set-aside from the CDBG is approximately 1.5 percent of the total appropriation, or $\$ 70.5$ million. The set-aside remained consistent at $\$ 67$ million between 1998 and 2000. In 2001 it received an increase of $\$ 3.8$ million, and then lost $\$ 0.8$ million the following year.

Indian Community Development Block Grant funds are dedicated for infrastructure and economic development, as well as housing on reservations and in Native Alaskan villages. Infrastructure improvements can include roads, water and sewer facilities, and community buildings. Eligible economic development activities include a variety of commercial, industrial, and agricultural projects. ${ }^{54}$ The Senate Indian Affairs Committee recommends that the amount be increased to at least 3 percent of the total CDBG or $\$ 144$ million. ${ }^{55}$

\section{Unmet Housing Needs}

Advocates argue that it is important to distinguish between Native American housing and housing programs for low-income families. The federal government has a special trust responsibility to Native American peoples, and as such, programs for their benefit should not be grouped with those that benefit low-income or rural populations in general. ${ }^{56}$ Moreover, while Native Americans have many of the same needs as other low-income populations, they also confront additional challenges. According to one Native American housing organization:

Unique financial barriers, remoteness, limited human resources, and land-use restrictions are factors not normally faced by public housing programs, but are among the most serious challenges for Indian communities. ${ }^{57}$

Irrespective of the trust responsibility, the fact that Native Americans do not have the housing opportunities available to other low-income communities - and that therefore housing conditions remain substandard-raises civil rights concerns. It is impossible to compare federal expenditures on lowincome housing nationally with housing expenditures in Native communities because HUD does not collect such data, nor does any other organization. However, it has been widely documented that Native American communities face unique challenges that demand greater federal resources than other public housing programs. While there have been improvements, largely as a result of NAHASDA, the dismal conditions on many reservations and tribal lands persist. ${ }^{58}$

\footnotetext{
${ }^{54}$ U.S. Department of Housing and Urban Development, Homes and Communities, "Indian Community Development Block Grant Program," <http://www.hud.gov:80/offices/pih/ih/grants/icdbg.cfm>.

${ }^{55}$ Senators Campbell and Inouye, letter to the Senate Committee on the Budget, Mar. 1, 2002, p. 135.

${ }^{56}$ Coalition for Indian Housing and Development, "Comments on Native American Issues from Responses to Millennial Housing Commission Solicitation Letter," <http://www.mhc.gov/responses.html>. See also Sossamon, "Tribes Need More Funds."

${ }^{57}$ Coalition for Indian Housing and Development, submission, p. 4.

${ }^{58}$ See George H. Cortelyou, "An Attempted Revolution in Native American Housing: The Native American Housing Assistance and Self-Determination Act," Seton Hall Legislative Journal, vol. 25 (2001), p. 429; Coalition for Indian Housing and Development, submission, p. 4; Housing Assistance Council, "Issues and Trends: Rural Housing in the U.S.," spring
} 
Federal housing funds are insufficient to compensate for the increased cost of construction on reservations. The expense of building in Native American communities is high because of geographic isolation, distance from urban centers, lack of infrastructure, and harsh climates that limit the construction season. It is estimated that labor costs in remote areas make up 65 percent of construction costs, compared with 50 percent generally. ${ }^{59}$ New housing projects are also time consuming because they must be coordinated among several federal agencies, including HUD, BIA, USDA, and HHS, as well as state agencies. ${ }^{60}$ Often there is overlap in responsibilities and lack of coordination between the federal agencies that administer housing-related programs from construction to sanitation services to rural development activities.

Additionally, the poor economic conditions of many Native communities render it impossible for residents to maintain their homes and pay rent, draining the scarce resources of tribally designated housing entities. Therefore, housing strategies will not work without simultaneous economic development programs to help communities become more self-sufficient. Federal housing subsidies can only go so far, especially if those subsidies remain as limited as they have been over the last several years. It is estimated that the current level of funding needed for housing in Native American communities is $\$ 1.1$ billion. $^{61}$

There has been a shortage of housing, combined with limited household resources, in these communities for decades. In two Lakota and Dakota communities, for example, 1,600 people are on waiting lists for housing. The funds received from NAHASDA for low-income housing will only provide enough to add 100 additional housing units per year, after allocating expenses for fund administration and maintenance of existing homes. Some households could remain on waiting lists for a decade or more, and yet it is speculated that even this calculation underestimates the real needs of the communities. ${ }^{62}$

These obstacles result in many housing deficiencies, but perhaps the greatest concern is overcrowding. It is not uncommon in Native communities for 25 to 30 people to share a single home. Overcrowding on Indian trust lands is six times the national rate, and in Alaska Native villages it is eight times the rate. ${ }^{63}$ In fact, more than a third of homes on reservations and more than 40 percent of homes in Alaska Native villages are overcrowded, compared with roughly 5 percent of the homes in the United States. ${ }^{64}$ The true extent of overcrowding may, in fact, be underestimated because no extensive studies have been done, and no federal agency has a comprehensive database that includes all reservation housing units and number of occupants. ${ }^{65}$ Moreover, census counts rely on self-reporting, and public housing residents are not likely to report the true number of occupants for fear of violating tenant occupancy rules.

One reservation story illustrates the extreme overcrowding characteristic of many who reside on reservations. A one-bedroom house that was built in the 1960s as one of the first transitional low-

2003; U.S. Department of Housing and Urban Development and U.S. Department of the Treasury, One-Stop Mortgage Center Initiative in Indian Country: A Report to the President, October 2002; and Sossamon testimony.

${ }^{59}$ Hensen and Taylor, Native America at the New Millennium, p. 140.

${ }^{60}$ NAIHC, Too Few Rooms, p. 37.

${ }^{61}$ Coalition for Indian Housing and Development, submission, p. 8; Sossamon testimony, p. 2.

${ }^{62}$ NAIHC, Too Few Rooms, p. 31. The NAIHC study refers to the Dakota/Lakota communities as one to disguise the identity of study participants. However, they are two distinct nations consisting of several bands or tribes.

${ }^{63}$ National American Indian Housing Council, "Overcrowding is Extensive, Causing Host of Health Problems, According to Study," press release, Feb. 12, 2002.

${ }^{64}$ NAIHC, Too Few Rooms, p. 3.

${ }^{65}$ Ibid., p. 30. 
income housing units on a Dakota plains reservation - and was abandoned in the 1970s because of extreme deterioration - is now regularly occupied by a family of 12 to 18 people. Housing advocates describe the deteriorating condition of the house:

There is very little insulation in the house and the winds rip through it, even with plastic over the windows. In the winter, the single wood stove and the oven going full blast in the kitchen cannot keep the house warm. The roof over the bedroom is collapsing. Floors in the bedroom, kitchen, and front room are caving in. The electrical wiring is disintegrating. The bathroom fixtures spray water across the room. ... Household residents believe the young children have recurring illnesses because of the extreme cold in the bedroom and on the front room floor where they often sleep. ${ }^{66}$

This particular house, which was initially built to have a functional life of no more than five years, is eligible for a federally funded home rehabilitation program, but has received none because of the long waiting list for assistance. Stories like this one abound and reflect the acute need for federal intervention. Effects of overcrowding and substandard housing conditions contribute to the difficult climate of reservation life:

- Poorly constructed or dilapidated housing often offers little protection from the elements, such as harsh winters or extreme heat.

- Overcrowded and unsanitary conditions result in poorer health conditions and increased spreading of communicable, normally preventable, illnesses.

- Deteriorating houses lead to increased frequency of accidents, fires, and other hazards.

- Children living in overcrowded homes suffer from sleep deprivation and inability to concentrate in school. Family transience due to inadequate housing further affects school performance.

- Overcrowding often results in stress, which can magnify family dysfunction and eventually lead to alcohol and child abuse. ${ }^{67}$

Because many Native American cultures emphasize a commitment to one another's care, Native Americans often feel obligated to house extended families or neighbors when economic struggles or disasters result in loss of housing. With the existing housing shortage on reservations, the only alternatives are sharing housing, no matter how overcrowded the living situation becomes, or homelessness. Overcrowding on reservations and in Native villages is already severe, but as the Native population grows, the situation will intensify unless there are swift measures to build more housing. Homelessness is also becoming increasingly visible on reservations, with families living in cars, tents, abandoned buildings, or storage sheds. ${ }^{68}$

Because Native American housing units are built quickly and cheaply, they often deteriorate beyond repair. This, combined with growth in tribal populations and the return of many Native Americans to reservations, has resulted in a greater demand for housing than supply. ${ }^{69}$ In addition to housing construction itself, large investments are needed for the construction of water lines, sewage and sanita-

\footnotetext{
${ }^{66}$ Ibid., pp. $28-29$.

${ }^{67}$ Ibid., pp. 31-34.

${ }^{68}$ Ibid., pp. 30-31.

${ }^{69}$ Ibid., p. 27.
} 
tion facilities, electricity, and roads. ${ }^{70}$ Many reservation communities still need these basic infrastructure, particularly large tribes with an extensive land base. ${ }^{71}$

Because Indian land is held in trust by the Bureau of Indian Affairs, as discussed in chapters 1 and 2, private housing developers are deterred from developing markets on these lands. In addition, because federal trust land cannot be used as collateral, Native Americans have difficulty obtaining mortgages. Market-based housing programs, such as housing vouchers, are not effective in Indian Country because it lacks a real estate market. ${ }^{72}$ More federal funding is needed to enable Native Americans to secure loans through guarantee programs, which have proven effective, and through low-interest mortgage assistance. While HUD's home loan assistance programs have helped increase homeownership, the benefit is minimal because many households do not have adequate income to participate or are impeded by poor credit histories as a result of limited economic opportunities. ${ }^{73}$

Another unmet need is the lack of resources to remedy unforeseen and critical housing expenses caused by environmental and natural disasters. HUD has established an emergency fund for its public housing programs, but no such fund exists for Native American housing. The absence of such a fund was most evident when recently several tribes suffered from the effects of toxic black mold that infested their homes. ${ }^{74}$ The extreme health problems that arose forced emergency evacuations in many homes. While the total cost of remedying problems associated with this disaster has not been calculated, it is estimated that at least \$20 million is needed just for the reservations of North Dakota to resolve the mold problem.

The foregoing discussion has exemplified the housing needs of Native Americans living on reservations and tribal lands or in villages because those are the communities targeted by HUD's Native American programs. However, as noted earlier, a large percentage of Native Americans reside in urban areas (roughly 60 percent), and the number is growing. Although the socioeconomic conditions of urban Indians are slightly better than those living on reservations, they often still require federal housing assistance. Many who leave reservations for urban areas are not financially prepared for the higher housing costs. And many continue to live in poverty, in overcrowded and substandard conditions. ${ }^{75}$ NAHASDA funds are distributed directly to tribes and tribal housing entities, most of which limit their services to tribal members living on or near reservations, to the neglect of urban members. ${ }^{76}$

\section{Conclusion}

Housing needs on reservations and tribal lands cannot be met with the same interventions that HUD uses to meet rental housing or homeownership goals in the suburbs or inner cities. A more comprehensive approach is needed, and the government's trust responsibility to Native Americans is an im-

\footnotetext{
${ }^{70}$ Senators Campbell and Inouye, letter to the Senate Committee on the Budget, Mar. 1, 2002, p. 134.

${ }^{71}$ Sossamon, "Tribes Need More Funds."

${ }^{72}$ Coalition for Indian Housing and Development, submission, pp. 5-6.

${ }^{73}$ NAIHC, Too Few Rooms, p. 37.

${ }^{74}$ Ron Selden, "Families Sicken and Die in Mold-Plagued HUD Housing," Indian Country Today, Apr. $2,2002$.

${ }^{75}$ Hensen and Taylor, Native America at the New Millennium, p. 160.

${ }^{76}$ Ibid., p. 161.
} 
portant factor. ${ }^{77}$ Housing, and by extension adequate appropriations, is a component of that responsibility. $^{78}$

Research has shown that fostering tribal self-determination and providing tribes with local control of housing funds enable them to better meet the needs of their members. ${ }^{79}$ Many factors determine the housing needs of a community, including population size, environmental conditions, and socioeconomic self-sufficiency. According to housing experts, despite tribal support for NAHASDA and the local control it offers, the number one barrier to adequate housing in tribal communities and villages is lack of funding. ${ }^{80}$ Indeed, the same can be said for those Native Americans residing in urban areas. However, in addition to increasing funding, the federal government must make a strong commitment to address the housing needs of Native Americans and to expedite the process by which funds reach the people who need them most.

Given the extensive documentation of the unmet housing needs in Native American communities, it is astounding that funding for these programs has remained static, and in some cases has declined, over the years. Specifically, this analysis reveals that:

- Funding for HUD's Native American housing programs has not kept pace with the agency's total budget. During the review period, HUD's budget increased 62 percent, but Native American programs increased only 8.8 percent. This actually amounts to a decrease in spending power after accounting for inflation.

- Whether due to level funding or actual budget cuts, almost every Native American housing program at HUD has lost spending power. The Native American Housing Block Grant, which is the largest source of federal funding for Native housing, has lost value for three years in a row. The tribal housing loan guarantee program lost nearly 70 percent of its purchasing power between 1999 and 2003.

- Not all the housing grants appropriated and awarded in a given year are actually disbursed to tribes that year and may sometimes be carried over. This should not be interpreted to mean that, in any given year, there were more funds available than needed because, as this report demonstrates, housing needs are robust. Ultimately, not all funds are reaching those who need them most, either because of noncompliance or the complexities of the application and distribution process.

- The President's 2004 budget request continues to maintain level funding for Indian housing construction/improvement and decreases the federal guarantees for tribal activities by $\$ 1$ million and the Indian Housing Loan Guarantee Fund by $\$ 4$ million. ${ }^{81}$

NAHASDA, though limited in funding, has been praised for facilitating the housing construction and homeownership momentum and enabling tribes to improve infrastructure on reservations, but much more needs to be done. The basic standard of living of Native Americans remains well below that of the rest of the nation, with crumbling structures, unsanitary conditions, and overcrowding all too

\footnotetext{
${ }^{77}$ Youmans, "Native American Housing Needs," p. 2.

${ }^{78}$ Sossamon, "Tribes Need More Funds."

${ }^{79}$ Native American Indian Housing Council, "Six Case Studies: Tribal Self-Determination Utilizing NAHASDA Activities," November 2002, <http://naihc.net/News/index.asp?bid=2463>.

${ }^{80}$ Ibid.

${ }^{81}$ HUD, FY 2004 Budget Summary, Appendix A.
} 
common in Indian Country. Native American households often lack even basic provisions such as plumbing, electricity, and telephone lines. Moreover, they seldom have the infrastructure or the economic viability to enable improvements. These conditions are unacceptable in 21 st century America. As long as current housing problems remain unfixed, conditions will continue to deteriorate, requiring greater tribal and federal investments in the future. Native people are entitled to adequate, safe, and sanitary homes like other Americans. 


\section{Chapter 5: Department of Justice}

A volatile mixture of despair and lack of opportunity, burgeoning youth populations, and inadequate police resources contribute to what can only be described as a crisis. Of all the challenges that face tribes, these may be the most troubling and daunting. ${ }^{1}$

The U.S. Department of Justice (DOJ), by virtue of its law enforcement responsibility on trust lands and reservations, has a significant role in providing public safety services and supporting tribal justice systems. DOJ works with the Department of the Interior's Bureau of Indian Affairs (BIA) and tribal police to provide law enforcement, corrections, and judicial support in Indian Country. ${ }^{2}$ These three components are collectively referred to here as the criminal justice system. DOJ has two additional functions with respect to law enforcement in Native areas: (1) to administer funds that enable tribes to build the capacity to combat crime and promote public safety; and (2) to represent the United States in litigation brought for the benefit of Indian tribes and individuals, as well as in litigation by tribes or individuals against the United States. ${ }^{3}$

Jurisdictional divisions among tribal, federal, and state law enforcement agencies complicate and challenge the unique justice system that prevails in Indian Country. The government-to-government relationship between Native tribes and the United States has resulted in shared responsibility for law enforcement and corrections, and a complex web of systems. Jurisdictional laws have evolved over the last 200 years as self-governance and sovereignty have been redefined, and numerous court cases and legislative measures have established the existing criminal justice framework.

As early as 1817, Congress asserted federal jurisdiction over non-Indians for crimes committed against Indians, as well as over Indians for some crimes committed against non-Indians. Congress also established that the federal government did not have jurisdiction over Indian-on-Indian crimes, those crimes that have been punished by the tribe, or those for which a treaty specifically designates tribal jurisdiction. ${ }^{4}$ Seventy years later, however, Congress claimed federal jurisdiction over seven crimes. If committed by Indians in Indian Country, regardless of the victim's identity, murder, manslaughter, rape, assault with intent to kill, arson, burglary, and larceny are under federal authority. ${ }^{5}$ Seven additional crimes have since been added: kidnapping, incest, assault with a dangerous weapon, assault resulting in serious injury, attempted rape, robbery, and felonious molestation of a minor. ${ }^{6}$

\footnotetext{
${ }^{1}$ Eric Hensen, Jonathan B. Taylor, et al., Native America at the New Millennium (Cambridge, MA: Harvard University, John F. Kennedy School of Government, Project on American Indian Economic Development, November 2002 ), p. 132 (hereafter cited as Hensen and Taylor, Native America at the New Millennium).

${ }^{2}$ U.S. Department of Justice, Office of Tribal Justice, "Department of Justice Policy on Indian Sovereignty and Government-to-Government Relations with Indian Tribes," <http://www.usdoj.gov/otj/sovtrb.htm>.

${ }^{3}$ Ibid.

${ }^{4}$ Federal Enclaves Act of 1817 (also known as the General Crimes Act), ch. $92 \S 2,3$ Stat. 383 (codified as amended at 18 U.S.C. § 1152 (Supp. IV 1998)). See Michael J. Bulzomi, "Indian Tribal Sovereignty: Criminal Jurisdiction and Procedure," FBI Law Enforcement Bulletin, vol. 70, no. 6 (June 2001), p. 24 (hereafter cited as Bulzomi, "Criminal Jurisdiction and Procedure").

${ }^{5}$ Major Crimes Act of 1885, ch. $341 \S 9,23$ Stat. 385 (codified as amended at 18 U.S.C. $§ 1153$ (Supp. IV 1998)).

${ }^{6}$ Bulzomi, "Criminal Jurisdiction and Procedure," pp. 26-27.
} 
Matters were further complicated in 1953 when Congress passed a law terminating tribal authority over criminal and civil matters in six states and enabling other states to assume jurisdiction by passing state law or amending state constitutions. ${ }^{7}$ In 1978, the Supreme Court ruled in Oliphant $v$. Suquamish Indian Tribe that tribal courts have no jurisdiction over non-Indian defendants, reiterating precedent that reservations must submit to the territorial sovereignty of the United States. ${ }^{8}$ However, the decision only dealt with limitations to tribal power, not the federal responsibility to compensate for those limitations based on the trust relationship. The Court did not require the federal government to protect tribes or prosecute non-Indian offenders who commit crimes on tribal lands. Only in cases where an enforceable treaty already existed would the federal government be required to provide a justice system and law enforcement for a tribe. ${ }^{9}$

The federal government has treated tribal justice authority inconsistently, at times granting jurisdiction to tribes and at others revoking it. Simply stated, today, jurisdiction over crimes in Indian Country depends on the identity of the victim and the offender, the severity of the crime, and where the crime occurred. ${ }^{10}$ Under current laws, tribal criminal authority is restricted to misdemeanors, with sentences limited to one year in jail and/or a $\$ 5,000$ fine per offense. Tribes have the authority to create and design independent judicial and correctional systems to address these matters, but often a lack of funds from DOJ and BIA limits their ability to do so. The result has been a severe shortage of crime prevention, victim assistance, public safety, and correctional programs on tribal lands. Furthermore, when a criminal perpetrator is non-Indian, tribes and their members depend on the federal government to provide the same law enforcement benefits that other Americans receive from state and local governments. ${ }^{11}$ According to one legal expert, the federal government has not always honored this responsibility seriously, and Native Americans have become easy crime targets. Many offenders know that they can get away with committing minor offenses against Native Americans because the federal government is not likely to spend resources pursuing these crimes. ${ }^{12}$

The lack of federal resources and efforts to address these issues may explain why Native Americans are the victims of crime at more than twice the rate of all U.S. residents. ${ }^{13}$ The rate of victimization of Native American women is 50 percent higher than the next highest group, African American males. ${ }^{14}$ Crimes reported in Indian Country are twice as likely to be violent in nature than are those reported in the rest of the United States. In Alaska, Natives are also more likely to be victims of crime than any other group, particularly Native women whose victimization rates in both urban and rural areas far exceed state and national averages. ${ }^{15}$ Although the violent crime rate for Native Americans is highest in urban areas, the crime rate for rural Native Americans is more than twice that of rural

\footnotetext{
${ }^{7}$ Act of Aug. 15, 1953, ch. $50 \S 2$, 67 Stat. 588 (codified as amended at 18 U.S.C. $§ 1162$ (1994)); Bulzomi, "Criminal Jurisdiction and Procedure," p. 27.

${ }^{8}$ Oliphant v. Suquamish Indian Tribe, 435 U.S. 191, 216 (1978).

${ }^{9}$ Victor H. Holcomb, "Prosecution of Non-Indians for Non-Serious Offenses Committed Against Indians in Indian Country," North Dakota Law Review, vol. 75 (1999), p. 766 (hereafter cited as Holcomb, "Prosecution of Non-Indians for NonSerious Offenses").

${ }^{10}$ U.S. Department of Justice, “Jails in Indian Country, 2001,” Bureau of Justice Statistics Bulletin, May 2002 (hereafter cited as DOJ, "Jails in Indian Country").

${ }^{11}$ Holcomb, "Prosecution of Non-Indians for Non-Serious Offenses," p. 761.

12 Ibid.

${ }^{13}$ U.S. Department of Justice, Bureau of Justice Statistics, “American Indians and Crime,” February 1999.

${ }^{14}$ U.S. Department of Justice, Office of Justice Programs, Office on Violence Against Women, "STOP Violence Against Indian Women Discretionary Grant Program," Fiscal Year 2000 Continuation Application Guidelines.

${ }^{15}$ Alaska Advisory Committee to the U.S. Commission on Civil Rights, Racism's Frontier: The Untold Story of Discrimination and Division in Alaska, April 2002, p. 38 (hereafter cited as Alaska Advisory Committee, Racism's Frontier).
} 
whites. Moreover, Native Americans are more likely than any other racial or ethnic group to experience violence at the hands of someone of a different race. ${ }^{16}$

Despite the prevalence of crime, law enforcement in Native communities remains inadequate, with understaffed police departments and overcrowded correctional facilities. There are fewer law enforcement officers in Indian Country than in other rural areas and significantly fewer per capita than nationwide. In addition, per capita spending on law enforcement in Native American communities is roughly 60 percent of the national average. ${ }^{17}$

In addition to being the victims of crime more often, Native Americans are also overrepresented in jails and prisons. American Indians are incarcerated at a rate 38 percent higher than the national per capita rate. ${ }^{18}$ Alaska Natives are incarcerated at nearly twice the rate of their representation in the state population. ${ }^{19}$ The number of Native American youth in the federal prison system has increased 50 percent since $1994 .{ }^{20}$ Many Native Americans attribute disproportionate incarceration rates to unfair treatment by the criminal justice system, including racial profiling, disparities in prosecution, and lack of access to legal representation. Because of burgeoning crime and lack of prevention programs, jails in Indian Country regularly operate beyond capacity. In 2001, the 10 largest jails were at 142 percent capacity, and nearly a third of all tribal facilities were operating above 150 percent capacity. ${ }^{21}$ According to a DOJ study, in some Native jails resources are so scarce that inmates do not have blankets, mattresses, or basic hygiene items, such as soap and toothpaste. ${ }^{22}$

Many Native Americans have lost faith in the criminal justice system in Indian Country, in part due to its inadequacy and in part due to a perceived bias. The Commission and its State Advisory Committees have held numerous meetings with Native communities over the years, and the sentiment remains unchanged: Native Americans face disparate treatment by law enforcement officials at every level. ${ }^{23}$ In South Dakota, for example, a strong perception exists among Native Americans that there is a dual system of justice and that race is a critical factor in determining how law enforcement is carried out. ${ }^{24}$ Many contend that violent crimes involving Native Americans are dealt with differently from those involving whites and that violence against Natives is investigated and prosecuted less vigorously. Other problems have been evident, including racial profiling in Indian Country and disparities in arrests, prosecution, legal representation, and sentencing. ${ }^{25}$

\footnotetext{
${ }^{16}$ U.S. Department of Justice, Office of Justice Programs, Bureau of Justice Statistics, American Indians and Crime, February 1999.

${ }^{17}$ Hensen and Taylor, Native America at the New Millennium, p. 136. See table 5.5.

${ }^{18}$ Hensen and Taylor, Native America at the New Millennium, p. 132.

${ }^{19}$ Alaska Advisory Committee, Racism's Frontier, p. 43.

${ }^{20}$ Chyrl Andrews, "OJJDP Tribal Youth Program," Juvenile Justice Journal, vol. 7, no. 2 (December 2000), $<$ http://www.ncjrs.org/html/ojjdp/jjnl_2000_12/contents.html> (hereafter cited as Andrews, "Tribal Youth Program").

${ }^{21}$ DOJ, "Jails in Indian Country," p. 3.

${ }^{22}$ U.S. Department of Justice, "Final Report to the Executive Committee for Indian Country Law Enforcement Improvements," Oct. 31, 1997, <http://www.usdoj.gov/otj/icredact.htm>.

${ }^{23}$ See, e.g., U.S. Commission on Civil Rights, Justice, 1961; U.S. Commission on Civil Rights, The Southwest Indian Report, May 1973; U.S. Commission on Civil Rights, Enforcement of the Indian Civil Rights Act, hearing held in Rapid City, South Dakota, July/August 1986; Oklahoma Advisory Committee to the U.S. Commission on Civil Rights, Selected Administration of Justice Issues Affecting American Indians in Oklahoma, September 1989.

${ }^{24}$ South Dakota Advisory Committee to the U.S. Commission on Civil Rights, Native Americans in South Dakota: An Erosion of Confidence in the Justice System, March 2000, p. 37 (hereafter cited as South Dakota Advisory Committee, Native Americans in South Dakota).

${ }^{25}$ South Dakota Advisory Committee, Native Americans in South Dakota, p. 37.
} 
In Alaska, as with many rural Native communities, the administration of justice is complicated by the remoteness of villages and towns. As one Alaska Native noted, in Native areas, justice services are "both qualitatively and quantitatively inferior to those provided in the state's non-Native communities." 26 Many Alaska Natives also believe that they are treated unfairly by the criminal justice system, and that when they are victims of crimes, their cases are low priority. ${ }^{27}$ Members of the Alaska Native community attribute the higher rates of incarceration among Natives to differential treatment by the criminal justice system, lack of access to adequate counsel, and racial profiling. ${ }^{28}$

The U.S. criminal justice system conflicts in many respects with traditional views of justice held by Native American communities. Whereas the U.S. system is based on an intricate series of laws and procedures, Native systems of justice are often guided by custom, tradition, and practices learned through the oral teachings of elders. ${ }^{29}$ The goal of the Native justice system is to achieve harmony in the community and make reparations. For many Native Americans, lack of familiarity with the "foreign" and often adversarial method of justice characteristic of the federal government foster a cultural divide and further mistrust. The complexity of the jurisdictional division among federal, state, and tribal governments adds to the breakdown of law and order in Native communities. ${ }^{30}$ Moreover, for the law enforcement system to be effective, it must also make allowances for an intricate network of cultural and social factors. For example, alcohol and/or substance abuse borders on epidemic in Native communities, and plays a significant role in crime and victimization in Indian Country, demanding law enforcement that has corrective as well as punitive goals. ${ }^{31}$

There is consensus among law enforcement professionals that the problems with the criminal justice system in Indian Country are serious and often understated. ${ }^{32}$ Recognizing increasing crime rates and sparse law enforcement, DOJ has made attempts in recent years to better serve Native American communities through collaboration with tribal leaders and increased presence. In 1995, the department launched the Indian Country Justice Initiative to reassess how the agency supports tribal law enforcement and to streamline its internal programs and resources. The Office of Tribal Justice was created to increase the responsiveness of the agency to tribes. Another primary resource for funding and technical assistance is the American Indian and Alaska Native Affairs Desk in the Office of Justice Programs (OJP), which is the primary grant-making agency within the department. These two offices coordinate on departmentwide Native American initiatives.

Other OJP offices have law enforcement responsibilities in Native communities, including the Bureau of Justice Assistance, Office of Juvenile Justice and Delinquency Prevention, Office for Victims of Crime, and the Office on Violence Against Women. The Federal Bureau of Prisons, Federal Bureau of Investigation (FBI), and Office of Community Oriented Policing Services (COPS) also pro-

\footnotetext{
${ }^{26}$ Alaska Advisory Committee, Racism's Frontier, p. 36, quoting John Angell, professor emeritus, University of Alaska at Anchorage.

${ }^{27}$ Alaska Advisory Committee, Racism's Frontier, p. 37.

${ }^{28}$ Ibid., p. 43.

${ }^{29}$ Ada Pecos Melton, president, American Indian Development Associates, "Indigenous Justice Systems and Tribal Society,"<http://www.ojp.gov/nij/rest-just/ch1/indigenous.htm>.

${ }^{30}$ South Dakota Advisory Committee, Native Americans in South Dakota, p. 38.

${ }^{31}$ Stewart Wakeling et al., "Policing on American Indian Reservations: A Report to the National Institute of Justice," Harvard Project on American Indian Economic Development, July 2001 (hereafter cited as Wakeling et al., "Policing on American Indian Reservations"); U.S. Department of Justice, Office of Justice Programs, Promising Practices and Strategies to Reduce Alcohol and Substance Abuse Among American Indian and Alaska Natives, an OJP Issues and Practices Report, August 2000.

${ }^{32}$ Holcomb, "Prosecution of Non-Indians for Non-Serious Offenses," pp. 779-80.
} 
vide services - directly and indirectly - in Indian Country. Figure 5.1 shows the offices at DOJ that support Native American programs as discussed in this report.

\section{FIGURE 5.1}

Organization Chart of Selected DOJ Offices Participating in Native American Programs

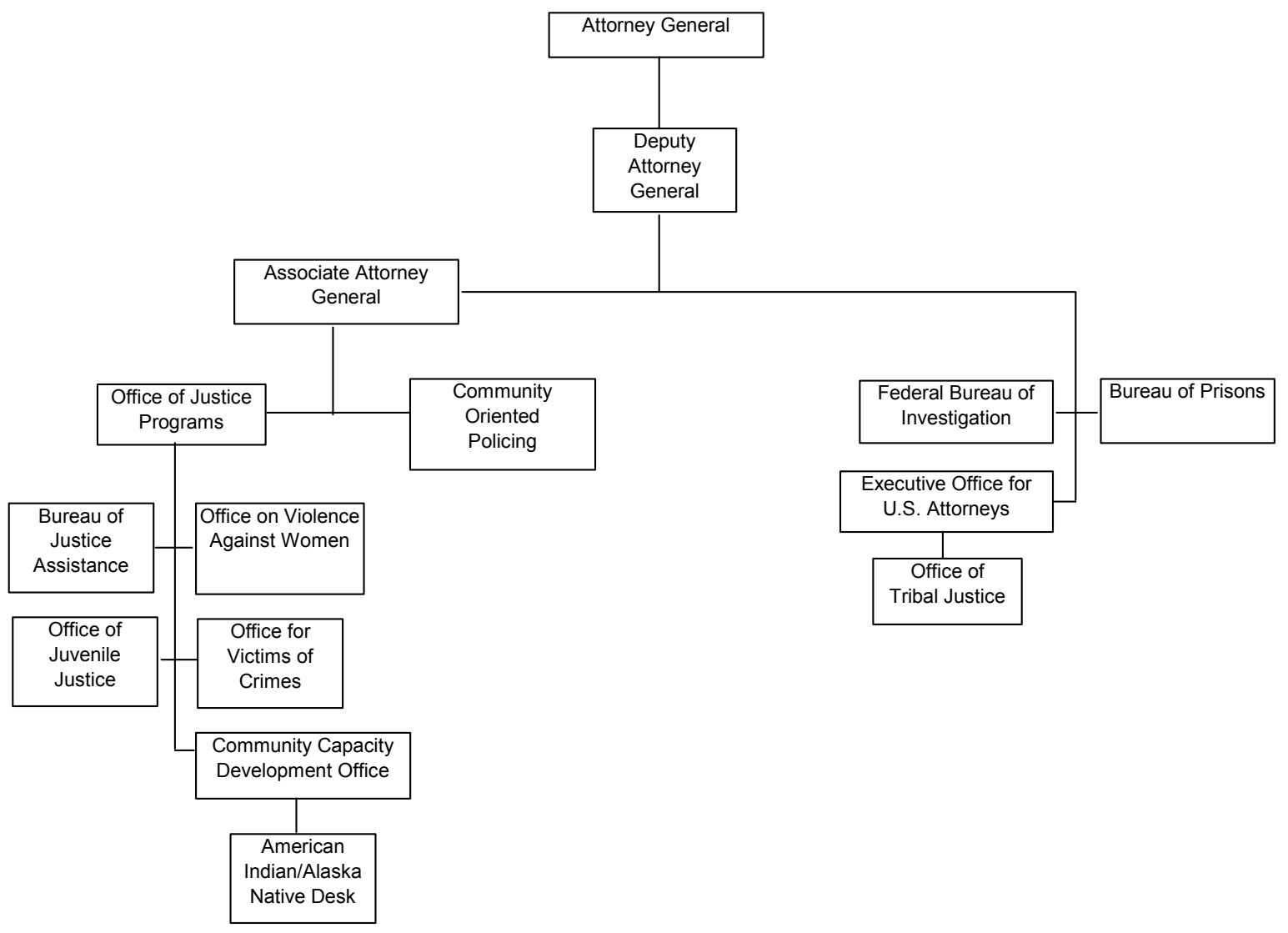

Sources: U.S. Department of Justice, "Organization Chart," Jan. 17, 2003, <http://www.usdoj.gov/dojorg.htm>; U.S. Department of Justice, Office of Justice Programs, "Organization of OJP," <http://www.ojp.usdoj.gov/org.htm>.

\section{DOJ Funding of Native American Programs}

The Department of Justice, although large in stature, receives a relatively small percentage of the federal government's total annual budget authority (averaging roughly 1.1 percent for each of the last six years). ${ }^{33}$ Its budget authority has averaged \$21 billion per year since 1998. DOJ's budget has undergone moderate fluctuation in recent years. Between 1998 and 2003, its budget authority increased 23.3 percent, and its discretionary budget increased 5.4 percent (see table 5.1). During that same period, the department's expenditures on Native American programs increased 86.7 percent, a significant increase that reflects recognition of the need to improve services to Native communities. However, funding for Native American programs has remained at roughly 1 percent of the department's total discretionary budget for the last six years. In other words, although Native American funding

\footnotetext{
${ }^{33}$ Office of Management and Budget, Budget of the United States Government, Fiscal Year 2004, Historical Tables, table 5.3, pp. 99-100.
} 
increased a significant percentage, it was a small amount to begin with, so its proportion to the agency's entire budget authority remained virtually unchanged.

TABLE 5.1

DOJ Budget Authority, Discretionary Budget, and Native American Program Funding, FY 1998-2004 (in millions of dollars)

\begin{tabular}{lrrrrrrr}
\hline & $\mathbf{1 9 9 8}$ & $\mathbf{1 9 9 9}$ & $\mathbf{2 0 0 0}$ & $\mathbf{2 0 0 1}$ & $\mathbf{2 0 0 2}$ & $\mathbf{2 0 0 3}$ & $\mathbf{2 0 0 4}$ \\
\cline { 2 - 7 } Budget Authority & 19,245 & 19,922 & 19,195 & 22,683 & 21,315 & 23,730 & 22,650 \\
Percent change from previous year & & $3.5 \%$ & $(3.6 \%)$ & $18.2 \%$ & $(6.0 \%)$ & $11.3 \%$ & $(4.6 \%)$ \\
\cline { 2 - 7 } Discretionary Budget & 18,057 & 18,911 & 19,313 & 21,942 & 19,677 & 19,036 & 17,697 \\
Percent change from previous year & & $4.7 \%$ & $2.1 \%$ & $13.6 \%$ & $(10.3 \%)$ & $(3.3 \%)$ & $(7.0 \%)$ \\
Native American Programs & 119.1 & 181.9 & 195.0 & 201.8 & 258.7 & 222.4 & 220.6 \\
Percent change from previous year & & $52.7 \%$ & $7.2 \%$ & $3.5 \%$ & $28.2 \%$ & $(14.0 \%)$ & $(0.8 \%)$ \\
Percent of total budget authority & $0.6 \%$ & $0.9 \%$ & $1.0 \%$ & $0.9 \%$ & $1.2 \%$ & $0.9 \%$ & $1.0 \%$ \\
Percent of discretionary budget & $0.7 \%$ & $1.0 \%$ & $1.0 \%$ & $0.9 \%$ & $1.3 \%$ & $1.2 \%$ & $1.2 \%$ \\
\hline * Estimate bas\%
\end{tabular}

* Estimate based on 2004 budget request.

Sources: Office of Management and Budget, Budget of the United States Government, Fiscal Year 2004, tables 5.2 and 5.4, pp. 95-96, 10304; U.S. Department of Justice, Justice Management Division, Budget Staff, "Detailed Federal Funding for Government-wide Native American Programs," submitted via facsimile, Apr. 10, 2003; U.S. Department of Justice, Justice Management Division, Budget Staff, "FY 2004 Detailed Federal Funding for Government-wide Native American Programs," submitted via facsimile, Apr. 29, 2003.

As table 5.1 illustrates, funding for Native American programs increased most dramatically between fiscal years 1998 and 1999 (52.7 percent), and again between 2001 and 2002 (28.2 percent). Even after allowing for inflation, DOJ's total Native American funding increased roughly \$91.1 million, approximately 69.3 percent, between 1998 and 2003. This upward trend holds true for both Office of Justice Programs funding and other departmental programs (see table 5.2). However, between 2002 and 2003, the amount of total funding for Indian programs decreased by 14 percent, indicating a withdrawal from previous support for these programs. The 2004 budget request, if approved, would again decrease funding by roughly 1 percent. After adjusting for inflation, the proposed decrease is actually 3 percent.

The Department of Justice, in reporting its expenditures on Native American programs, includes costs associated with direct assistance to Native communities (whether through grants or services), as well as costs for public services from which Native Americans benefit. For example, the department includes FBI expenditures for law enforcement in rural areas that encompass reservations and trust lands and the amount the Bureau of Prisons spends on incarcerated Native Americans. Because reporting is so inclusive, the amounts spent specifically on Native American programs cannot be precisely extracted.

An isolated analysis of OJP spending provides a clearer picture. OJP's Native American programs primarily administer grants and services (technical assistance, training, research, etc.) for tribes. Funding for these programs more than doubled between 1998 and 1999 and then fluctuated in ensuing years. Between 2001 and 2002 it nearly doubled again, but then was reduced by roughly 43 percent in 2003. Native American programs constitute, on average, 1.6 percent of OJP's total budget each year (table 5.3). 
TABLE 5.2

DOJ Funding for Native American Programs in Real and Constant 2003 Dollars, FY 1998-2004 (in thousands of dollars)

\begin{tabular}{|c|c|c|c|c|c|c|c|}
\hline & 1998 & 1999 & 2000 & 2001 & 2002 & $2003^{*}$ & $2004^{* *}$ \\
\hline \multicolumn{8}{|l|}{ OJP Activities } \\
\hline Real dollars & 28,583 & 62,963 & 62,870 & 54,849 & 101,009 & 57,748 & 50,728 \\
\hline Constant 2003 dollars & 31,520 & 68,341 & 66,524 & 56,761 & 102,933 & 57,748 & 49,797 \\
\hline \multicolumn{8}{|l|}{ Other DOJ } \\
\hline Real dollars & 90,482 & 118,965 & 132,147 & 146,920 & 157,672 & 164,604 & 169,844 \\
\hline Constant 2003 dollars & 99,779 & 129,127 & 139,827 & 152,042 & 160,675 & 164,604 & 166,728 \\
\hline \multicolumn{8}{|l|}{ Total DOJ } \\
\hline Real dollars & 119,065 & 181,928 & 195,017 & 201,769 & 258,681 & 222,352 & 220,572 \\
\hline Constant 2003 dollars & 131,299 & 197,468 & 206,350 & 208,804 & 263,607 & 222,352 & 216,526 \\
\hline
\end{tabular}

TABLE 5.3

Native American Programs as a Percentage of Total OJP Funding, FY 1998-2004 (in thousands of dollars)

\begin{tabular}{|c|c|c|c|c|c|c|c|}
\hline & 1998 & 1999 & 2000 & 2001 & 2002 & 2003* & $2004^{* *}$ \\
\hline OJP total budget & $4,769,464$ & $4,819,498$ & $3,984,070$ & $4,637,047$ & $4,258,348$ & $2,667,662$ & $2,300,178$ \\
\hline OJP Native American programs & 28,583 & 62,963 & 62,870 & 54,849 & 101,009 & 57,748 & 50,728 \\
\hline Percent of total & $0.6 \%$ & $1.3 \%$ & $1.6 \%$ & $1.2 \%$ & $2.4 \%$ & $2.2 \%$ & $2.2 \%$ \\
\hline
\end{tabular}

Table 5.4 shows funding by agency within the department and, within the Office of Justice Programs, each individual grant program. Over the years, notable increases were granted for Violence Against Women Act programs, corrections, and Community Oriented Policing, although funds for the latter two have steadily declined in recent years. The juvenile justice program budget, on the other hand, has been cut dramatically (nearly 80 percent) since 1998. Likewise, between 2002 and 2003 the budget for the At-Risk Children's Initiative was reduced by 40 percent, negating the significant increase it received between 2001 and 2002. The Native American portion of the Local Law Enforcement Block Grant has been phased out entirely, as have tribal drug courts. In addition, over the years, several programs have been proposed, but never funded: tribal youth mental health, police corps, sexual assault nurse examiners, drug testing and treatment, and an Indian law enforcement block grant. ${ }^{34}$

It should be noted that not all the programs in table 5.4 are legislatively mandated, and thus funding fluctuates depending on appropriations available, demand for specific grants, and the priorities of the administration and Congress. There are three basic categories of OJP programs available to Native

\footnotetext{
${ }^{34}$ U.S. Department of Justice, Justice Management Division, Budget Staff, "Detailed Federal Funding for Governmentwide Native American Programs," submitted via facsimile, Apr. 10, 2003.
} 
Americans: (1) required set-asides of larger legislatively authorized funds; (2) programs strictly targeting Native Americans, but which are not mandated; and (3) programs for which tribes are eligible along with other populations.

TABLE 5.4

DOJ Budget Authority for Native American Programs, FY 1998-2004 (in thousands of dollars)

\begin{tabular}{|c|c|c|c|c|c|c|c|}
\hline & 1998 & 1999 & $2000^{*}$ & 2001 & 2002 & $2003^{*}$ & $2004^{* *}$ \\
\hline Bureau of Prisons & 45,347 & 51,406 & 52,948 & 64,438 & 70,640 & 75,753 & 80,367 \\
\hline $\begin{array}{l}\text { Environment and Natural } \\
\text { Resources Division }\end{array}$ & 4,685 & 6,438 & 7,945 & 6,239 & 9,364 & 8,987 & 12,971 \\
\hline U.S. Attorneys & 9,686 & 10,053 & 10,078 & 15,391 & 18,500 & 19,299 & 19,910 \\
\hline Federal Bureau of Investigation & 8,869 & 13,550 & 16,031 & 16,706 & 19,840 & 21,242 & 21,909 \\
\hline Legal Activities & 4,839 & 4,642 & 5,145 & 4,173 & 4,328 & 4,550 & 4,687 \\
\hline Community Oriented Policing & 17,056 & 32,876 & 40,000 & 39,973 & 35,000 & 34,773 & 30,000 \\
\hline Subtotal & 90,482 & 118,965 & 132,147 & 146,920 & 157,672 & 164,604 & 169,844 \\
\hline \multicolumn{8}{|l|}{ Office of Justice Programs } \\
\hline Crime Victims Fund ${ }^{\wedge}$ & 2,500 & 1,500 & 1,500 & 1,358 & 4,760 & 4,600 & 4,600 \\
\hline Tribal Criminal Justice Statistics & -- & -- & -- & 1,144 & 210 & 1,983 & 2,000 \\
\hline Juvenile Justice Programs^^ & 1,800 & 1,600 & 1,600 & 296 & 398 & 387 & 398 \\
\hline At-Risk Children's Initiative & -- & 10,000 & 12,500 & 10,043 & 22,318 & 12,391 & 12,500 \\
\hline $\begin{array}{l}\text { State and Local Law } \\
\text { Enforcement Assistance }\end{array}$ & 2,257 & 925 & -- & -- & -- & -- & -- \\
\hline $\begin{array}{l}\text { Local Law Enforcement Block } \\
\text { Grant }\end{array}$ & 957 & -- & -- & 1,120 & 503 & -- & -- \\
\hline Violence Against Women Act^ ${ }^{\wedge}$ & 12,718 & 8,270 & 8,270 & 16,320 & 16,078 & 20,503 & 20,377 \\
\hline Drug Courts & 2,351 & 868 & -- & 3,351 & 2,686 & -- & -- \\
\hline Corrections & 5,050 & 34,000 & 34,000 & 19,453 & 44,363 & 4,968 & -- \\
\hline Tribal Courts & -- & 5,000 & 5,000 & 890 & 8,727 & 7,948 & 5,921 \\
\hline Exec. Office for Weed \& Seed & 950 & 800 & -- & 525 & 225 & -- & -- \\
\hline Civil/Criminal Legal Asst. & -- & -- & -- & 349 & 436 & -- & -- \\
\hline Alcohol and Substance Abuse & -- & -- & -- & -- & 305 & 4,968 & 4,932 \\
\hline Subtotal OJP & 28,583 & 62,963 & 62,870 & 54,849 & 101,009 & 57,748 & 50,728 \\
\hline Total DOJ & 119,065 & 181,928 & 195,017 & 201,769 & 258,681 & 222,352 & 220,572 \\
\hline \multicolumn{8}{|c|}{$\begin{array}{l}\text {-- Indicates that no funding was appropriated. } \\
\text { *Enacted amounts (actuals not available). } \\
\text { ** Estimate based on } 2004 \text { budget request. } \\
\text { ^ Native American set-aside funds that are legislatively required. } \\
\text { D Discretionary grant programs not specifically targeting Native Americans, but for which tribes are eligible. } \\
\text { Sources: U.S. Department of Justice, Justice Management Division, Budget Staff, "Detailed Federal Funding for Government-wide Native } \\
\text { American Programs," submitted via facsimile, Apr. 10, 2003; U.S. Department of Justice, Justice Management Division, Budget Staff, "FY } \\
2004 \text { Detailed Federal Funding for Government-wide Native American Programs," submitted via facsimile, Apr. 29, } 2003 \text {. }\end{array}$} \\
\hline
\end{tabular}




\section{DOJ Initiatives in Indian Country}

Most tribal police departments are funded through BIA contracts, although DOJ is in a unique position - as the law enforcement arm of the federal government - to provide resources, expertise, and services. The department has, in fact, taken initiative through increased grants and technical assistance in recent years. Momentum began in 1999 when the administration sought to bring tribal law enforcement up to adequate standards, thereby improving the quality of life for Native Americans living on reservations and trust lands. ${ }^{35}$

After a collaborative analysis of crime and justice on tribal lands, the Departments of Justice and Interior determined that law enforcement in Indian Country failed to meet basic safety needs. They identified the preeminent problem as lack of resources. ${ }^{36}$ This four-year collaboration, known as the Indian Country Law Enforcement Improvements Initiative, resulted in increased funding for tribal law enforcement and justice, including funding for police staffing, correctional facilities, juvenile justice programs, and tribal courts. ${ }^{37}$ Many of the programs included in the Law Enforcement Improvements Initiative, however, have lost funding since their initiation.

In fact, DOJ lists numerous initiatives that, because they are important, should be funded consistently. However, as table 5.4 illustrates, many programs undergo extreme funding fluctuations from year to year, and some have had funding eliminated altogether. For example, funding for the department's tribal youth program, which supports crime prevention and juvenile justice system improvements, has fluctuated from \$10 million in 1999 to $\$ 22.3$ million in 2002 to $\$ 12.4$ million in 2003 . $^{38} \mathrm{~A}$ grant program for Indian Country prison construction was funded at $\$ 44.4$ million in 2002 , but in 2003 was reduced to less than $\$ 5$ million, and the 2004 budget request proposes funding elimination altogether. ${ }^{39}$ The Tribal Drug Court Program, which is designed to integrate substance abuse treatment with sanctions and transitional services, received \$3.4 million in 2001 and \$2.7 million in 2002. The program was not funded in 2003, nor have funds been requested for $2004{ }^{40}$

These are just a few of the many programs the Department of Justice administers, which represent a wide array of law enforcement needs and resources. While many have proven worthwhile, none has the funding or budget stability necessary for maximum success. The department's commitment to tribal justice appears sincere with the development of innovative and badly needed programs, but its appropriations underestimate the true breadth of the challenges that remain in Indian Country. The commitment of Congress will be tested at the end of fiscal year 2003 when the Indian Country Law Enforcement Improvements Initiative, the source of many of these grant program, expires.

\footnotetext{
${ }^{35}$ U.S. Department of Justice, “Attorney General Reno Announces Major Initiative to Improve Indian Country Law Enforcement," Oct. 13, 1999, <http://www.usdoj.gov/opa/pr/1999/October/476ag.htm>.

${ }^{36}$ Kim Baca, "The Changing Federal Role in Indian Country," National Institute of Justice Journal, April 2001, pp. 9-11 (hereafter cited as Baca, "The Changing Federal Role in Indian Country"); see also U.S. Department of Justice, Office of Tribal Justice, Report of the Executive Committee for Indian Country Law Enforcement Improvements: Final Report to the Attorney General and Secretary of the Interior, October 1997, <http://www.usdoj.gov/otj/icredact.htm> (hereafter cited as OTJ, "Final Report to the Attorney General").

${ }^{37}$ Baca, "The Changing Federal Role in Indian Country," p. 11.

${ }^{38}$ U.S. Department of Justice, Office of Justice Programs, “Fiscal Year 2002 At-a-Glance,” May 2002.

${ }^{39}$ Ibid.

${ }^{40}$ U.S. Department of Justice, Office of Justice Programs, Bureau of Justice Assistance, “Tribal Drug Court Grant Program," <http://www.ojp.usdoj.gov/BJA/grant/tribal_drug.html>.
} 
As previously noted, DOJ's 2003 budget authority for Native American programs was $\$ 36.3$ million less than the preceding year. The President's 2004 budget request, if approved, would reduce appropriations by another $\$ 2$ million. Funding for OJP programs, which account for most of the direct Indian initiatives, would be reduced by roughly $\$ 7$ million. Because funding is so low relative to overall departmental spending, decreases, however slight, are magnified. Moreover, needs that remain unmet under these circumstances will inevitably multiply.

\section{Unmet Justice and Law Enforcement Needs}

\section{Basic Law Enforcement Services}

Perhaps one of the most urgent needs in Indian Country is access to basic law enforcement, which many of the 1.4 million Native Americans living on or near reservations and tribal lands lack. ${ }^{41}$ The Indian Self-Determination and Education Assistance Act of 1975 gave tribes the opportunity to establish their own law enforcement bodies through contracts with BIA. ${ }^{42}$ Most tribal police departments in existence today fall under this category, while others are directly administered by BIA or rely on state and local authorities. ${ }^{43}$

There are more than 200 police departments in Indian Country, ranging in size from two officers to roughly 200 . The populations they serve are as small as 600 and as large as $250,000 .{ }^{44}$ According to DOJ research, the typical tribal police department serves an area the size of Delaware with a population of 10,000 . These areas are patrolled by no more than three police officers, and as few as one at a time. This reflects a level of police coverage that is much lower than any other in the United States, and which is attributed to inadequate funding. ${ }^{45}$ Table 5.5 illustrates the disparity; fewer dollars are spent per capita on law enforcement in Indian Country than nationally or even in comparable rural areas. It is estimated that tribes have between 55 and 75 percent of the resources available to nonIndian communities, a figure that is even more exaggerated considering the higher crime rates. Large cities such as New York, Washington, D.C., and Detroit provide between four and seven officers per thousand residents, whereas few departments in Indian Country have more than two per thousand. ${ }^{46}$

TABLE 5.5

Resources Available to Indian and Non-Indian Police Departments

\begin{tabular}{lcccc}
\hline & $\begin{array}{c}\text { Indian } \\
\text { Country }\end{array}$ & $\begin{array}{c}\text { Comparable } \\
\text { Rural Areas }\end{array}$ & National Average & $\begin{array}{c}\text { Comparable } \\
\text { High-Crime } \\
\text { Areas }\end{array}$ \\
\cline { 2 - 5 } Officers per 1,000 residents & 1.3 & $1.8-2.0$ & 2.3 & $3.9-6.6$ \\
Dollars per capita & $\$ 83$ & $\$ 104$ & $\$ 131$ & -- \\
Dollars per employee & $\$ 36,000$ & $\$ 43,400$ & $\$ 48,200$ & -- \\
\hline
\end{tabular}

Source: Eric Hensen, Jonathan B. Taylor, et al., Native America at the New Millennium (Cambridge, MA: Harvard University, John F. Kennedy School of Government, Project on American Indian Economic Development, November 2002) p. 136, citing Stewart Wakeling et al., "Policing on American Indian Reservations: A Report to the National Institute of Justice," Harvard Project on American Indian Economic Development, July 2001, p. 17.

\footnotetext{
${ }^{41}$ Andrews, "Tribal Youth Program."

${ }^{42}$ Indian Self-Determination and Education Assistance Act of 1975, Pub. L. No. 93-638, 88 Stat. 2206 (codified as amended in scattered sections of 5 U.S.C. and 25 U.S.C.).

${ }^{43}$ Wakeling et al., "Policing on American Indian Reservations," pp. v-vi.

${ }^{44}$ Ibid., p. v.

${ }^{45}$ Ibid., p. vi.

${ }^{46}$ Ibid., p. vii.
} 
These numbers, however stark, still underestimate the true insufficiency of law enforcement on Native American lands. The population served by Indian police agencies is larger than the Indian population itself because many non-Indians use tribal services, roads, land, and public places. Second, tribal police districts encompass large geographic areas, rendering regular police patrolling impossible, especially when compounded by harsh climates. ${ }^{47}$ DOJ estimates that nearly 4,300 officers are needed to provide basic public safety in Indian Country, roughly twice the current number of officers. ${ }^{48}$

The state of Alaska is largely responsible for providing law enforcement to its Native villages and remote communities. Village public safety officers, who report to state troopers, receive less training and pay than troopers, and are not allowed to intervene in major criminal cases, leaving villages vulnerable to crime. ${ }^{49}$ One-third of the 226 Native Alaskan villages are without any form of law enforcement, rendering them "virtually defenseless to lawbreakers." ${ }^{\text {, }}$ More than 80 percent of the population in Alaska receiving full protection from state troopers are non-Native, whereas 80 percent of the population that receive limited or no local police protection are Native.

Lack of adequate law enforcement has other serious outcomes; Native individuals and communities do not derive the deterrence benefit of an adequate police presence, and the result has been increased criminal behavior and victimization of residents in areas known for inadequate policing. The failure of the federal government to fully acknowledge and remedy policies that have a disproportionately negative effect on a group of people, and to continue following such policies, jeopardizes the safety of the group compared with other Americans and constitutes discrimination. ${ }^{51}$

The need for adequate law enforcement in Indian Country is most important today. With national security a priority throughout the country, and particularly along its borders, more money is being allocated to public safety than ever. Yet, Native American communities, many of which occupy border lands and house important energy and agricultural resources, have been left out of the homeland security resource pool.

\section{Tribal Courts}

It is widely agreed among Native American leaders that tribal courts play an important role in Native communities. Tribal courts not only confront issues of self-determination and sovereignty, but are charged with providing reliable and equitable adjudication to the many matters that come before them. ${ }^{52}$ Accordingly, tribal justice systems are the primary institutions for maintaining order on reservations. Former Attorney General Janet Reno noted that fulfilling the federal government's trust responsibility to Indian nations means not only providing adequate law enforcement, but also enhancing tribal courts. ${ }^{53}$ Although these courts do not have authority to adjudicate complex criminal

\footnotetext{
${ }^{47}$ Gary L. Edwards, chief executive officer, National Native Law Enforcement Association, testimony before the Senate Committee on Indian Affairs, Feb. 26, 2003, p. 5.

${ }^{48}$ Ibid.

${ }^{49}$ Alaska Advisory Committee, Racism's Frontier, p. 39.

${ }^{50}$ Ibid., quoting Lare Aschenbrenner, directing attorney, Native American Rights Fund, Alaska office, written submission to the Alaska Advisory Committee to the U.S. Commission on Civil Rights, Oct. 26, 2001, p. 9.

${ }^{51}$ Holcomb, "Prosecution of Non-Indians for Non-Serious Offenses," p. 769.

52 Jill E. Shibles, president, National American Indian Court Judges Association, testimony before the Senate Committee on Indian Affairs, June 3, 2003 (hereafter cited as Shibles testimony).

${ }^{53}$ Shibles testimony, citing “A Federal Commitment to Tribal Justice Systems," Judicature, vol. 79 , no. 7 (November/December 1995), p. 114.
} 
cases, they do confront many of the same problems as state and federal courts, but with considerably fewer resources.

Tribal justice systems have been underfunded for decades. At hearings in 1986 and 1988, the Commission was told that funding for tribal courts was inadequate, preventing their proper functioning and suggesting that ensuring a fair system of justice in Indian Country was not a federal priority. ${ }^{54}$ As noted by one Native American legal advocate:

I think it is important that the government decide what its commitment is to tribal government. If it believes that there should be a tribal government and a reservation system, then it should give the funding, provide the means, for that court system to operate like any other court system. ${ }^{55}$

Again in 1991, the Commission found that lack of funding had hampered the effectiveness of tribal courts for more than 20 years. ${ }^{56}$ In 1993, with the passage of the Indian Tribal Justice Act, tribes were to receive $\$ 58.4$ million per year to create and expand their justice systems. ${ }^{57}$ By the time the act expired in 1999, only $\$ 5$ million had actually been appropriated. ${ }^{58}$ This analysis reveals sporadic and insufficient funding in recent years as well. DOJ's tribal courts program was initially funded at \$5 million in 1999 as a component of the Indian Country Law Enforcement Initiative. Funding held steady the following year and then was reduced to less than \$1 million in 2001 (see table 5.4 above). In 2002, the amount of funding increased significantly to $\$ 8.7$ million, but has since declined to $\$ 7.9$ million in 2003. The proposed 2004 budget includes less than $\$ 6$ million for the tribal courts program. Considering there are more than 250 tribal courts and intertribal court systems, this amount is insufficient. ${ }^{59}$

When surveyed about the most urgent funding needs, tribal court officials responded that the most critical was funding for construction or renovation of tribal justice facilities. This was followed by funding to employ and train additional judicial and court personnel. ${ }^{60}$ Funding for technical assistance is also needed as new court systems are developed. The National American Indian Court Judges Association notes that the \$58 million annual appropriation promised under the Indian Tribal Justice Act would go a long way toward fulfilling the needs of tribal courts. At least, it argues, tribal courts should be funded at $\$ 15$ million per year, more than twice the 2003 appropriation, which would enable their enhancement and continued operation. ${ }^{61}$

The implications of inadequate funding for tribal courts are far-reaching. As long as tribal courts are underfunded and unable to deal with tribal jurisprudence, the burden for criminal justice will continue to fall on the federal court system, where sentences are typically harsher, perpetuating a system

\footnotetext{
${ }^{54}$ See U.S. Commission on Civil Rights, Enforcement of the Indian Civil Rights Act: Hearing Held in Rapid City, South Dakota, July 31, Aug. 1, and Aug. 21, 1986 (hereafter cited as USCCR, Rapid City Hearing, 1986); U.S. Commission on Civil Rights, Enforcement of the Indian Civil Rights Act: Hearing Held in Portland, Oregon, Mar. 31, 1988.

${ }^{55}$ USCCR, Rapid City Hearing, 1986, statement of Anita Remerowski, former director, Dakota Plains Legal Services.

${ }^{56}$ U.S. Commission on Civil Rights, The Indian Civil Rights Act, June 1991, p. 72.

${ }^{57}$ Indian Tribal Justice Act of 1993, Pub. L. No. 103-176, 107 Stat. 2007 (codified as amended at 25 U.S.C. § 3613 (1994)).

${ }^{58}$ Nancy Thorington, "Civil and Criminal Jurisdiction Over Matters Arising in Indian Country: A Roadmap for Improving Interaction Among Tribal, State and Federal Governments," McGeorge Law Review, vol. 31 (summer 2000), p. 987.

${ }^{59}$ U.S. Department of Justice, Office of Justice Programs, Bureau of Justice Assistance, “Competitive Grant Announcement: Awards for Developing, Implementing, Enhancing, and Operating Tribal Courts,” May 25, 2001.

${ }^{60}$ Shibles testimony.

${ }^{61}$ Mary T. Wyne, president, National American Indian Court Judges Association, testimony before the House Appropriations Committee, Subcommittee on Commerce, Justice, State, and Judiciary, Mar. 31, 2000, p. 5.
} 
of dual justice for Native Americans on reservations. Moreover, effective resolution of civil disputes is an essential component of the governance infrastructure that tribes must provide. Thus, in addition to ensuring order and justice, tribal courts are a key to economic development and self-sufficiency. ${ }^{62}$

\section{Correctional Facilities}

Detention facilities in Indian Country are inadequate in many respects. According to a DOJ report, Indian Country jails fall far short of basic professional standards due to a shortage of operating funds, training, and technical assistance. The department notes that operations are substandard in such critical areas as staff and inmate safety, inmate services and programs, fire safety, communicable disease prevention, sanitation, and hazardous substance control. ${ }^{63}$ In addition, detention facilities in Native communities are often antiquated, inadequate, and out of compliance with building codes. Most jails were designed as high-security facilities, without consideration for their population: most inmates in Indian Country jails are those who have been found guilty of misdemeanor offenses. ${ }^{64}$ State and federal prisons, on the other hand, separate violent and felony offenders from those convicted of minor crimes.

These insufficiencies are compounded by the fact that, in many tribal areas, overcrowding in correctional facilities is severe. ${ }^{65}$ For example, at midyear 2001, the Pine Ridge Correctional Facility in South Dakota housed 168 inmates, more than 7.5 times its capacity of 22. The Tohono O'odham Detention Center in Arizona housed three times its operating capacity. The Navajo Department of Corrections-Window Rock in Arizona was nearly 65 percent above capacity. Overall, the 10 largest jails in Indian Country were at 142 percent capacity, and 21 of all 68 tribal facilities were operating above 150 percent capacity. ${ }^{66}$ Prisons across the United States also are overcrowded, but not nearly to the extent of those in Indian Country. At year-end 1998, the most recent year for which data are available, the federal prison system was operating at 27 percent over capacity, and state prisons overall were operating at 13 percent above their highest capacity. ${ }^{67}$

This stark disparity reveals the need to increase funding for tribal correctional facilities, but Congress and DOJ have failed to even maintain level funding over the last few years. In fiscal year 2002, \$35.2 million was provided to construct detention facilities in tribal areas. As of May 2002, 16 facilities had received grants for expansion, renovation, or construction; 17 additional facilities had received administrative approval for modification, but funding was still pending. ${ }^{68}$ The estimated backlog for construction is $\$ 400$ million, yet the 2003 enacted budget includes less than $\$ 5$ million for tribal detention facilities. The 2004 request provides no funding at all (see table 5.4).

While funding for facility construction and improvement is important, it is also necessary that DOJ, in conjunction with other federal agencies, determine why incarceration rates in Native communities are so high, resulting in overcrowding. If it is determined that this is the result of unfair sentencing, lack of access to counsel, or other disparities in the system, it should be addressed immediately. The

\footnotetext{
${ }^{62}$ Ibid., p. 7.

${ }^{63}$ OTJ, "Final Report to the Attorney General," tab D.

${ }^{64}$ Ibid.

${ }^{65}$ Sixty-eight detention facilities operate in Indian Country, with the capacity to hold roughly 2,100 individuals. DOJ, "Jails in Indian Country," p. 3.

${ }^{66}$ DOJ, “Jails in Indian Country," p. 3.

${ }^{67}$ U.S. Department of Justice, Office of Justice Programs, "Prisoners in 1998," Bureau of Justice Statistics Bulletin, August 1999.

${ }^{68}$ DOJ, “Jails in Indian Country,” p. 4.
} 
agency must also provide program funding to deter criminal behavior and develop alternatives to incarceration.

\section{Conclusion}

The Commission has long documented persistent disparities in the criminal justice system among racial and ethnic groups. Native American communities are among the most underserved in the nation. As this chapter has highlighted, there are fewer law enforcement officers per capita in Indian Country than other rural and high-crime areas. Native Americans are the victims of crimes, especially violent crimes, at rates exceeding those of other groups in the United States. They are also overrepresented in the correctional system, a fact that is attributed to unfair police practices, disparities in prosecution rates, and lack of access to legal representation. Race is thus a critical factor in law enforcement outcomes.

Law enforcement officials acknowledge the magnitude of the problems and identify lack of funding as a primary factor. Funding for criminal justice systems in Indian Country remains insufficient to meet the immediate needs of these communities, much less establish a framework for eventual selfsufficiency. The potential for even modest progress will be undone if funding cutbacks continue as they have in recent years. The Commission's analysis reveals the following about Department of Justice funding for Native American programs:

- During the review period, the agency's expenditures on Native American programs increased at a faster rate than its overall budget authority. However, because funding for Native American programs is so comparatively small, its proportion to the department's budget has remained unchanged, at roughly 1 percent.

- Despite overall increases between 1998 and 2003, a downward trend has begun: between 2002 and 2003 the amount of total funding for Indian programs decreased by 14 percent, and OJP funding for such programs decreased by roughly 43 percent. The President's 2004 budget request, if approved, would continue this downward trend.

- Some Native American programs have received notable increases over the years, but others have faced significant budget cuts. Still others have been phased out entirely or proposed but never funded.

Because many of DOJ's Native American programs are not statutorily required, they are subject to the priorities of appropriators, and as a result, funding fluctuates from year to year. This fractured funding negatively affects program development and delivery. Moreover, the jurisdictional division among tribal, federal, and state law enforcement agencies, as well as that between DOJ and BIA, has resulted in a complex and uncoordinated system.

Public safety is fundamental to the preservation of communities, and the federal government has a trust responsibility to Native peoples to support law enforcement and judicial systems on par with the rest of the population. Yet, every day the safety of Native Americans is compromised by the federal government's failure to meet this responsibility. According to one commentator:

The government's failure to provide the promised protection becomes the means by which the wrongdoers are allowed to operate, and the government is essentially an accessory to the wrongdoing. . . . By establishing itself as the exclusive means by which [non-serious] crimes 
are prosecuted, but then failing to honor this obligation, it is in fact the government that is responsible for the deprivation of these essential freedoms without any process of law. ${ }^{69}$

The federal government has maintained jurisdictional authority over most criminal activity in Indian Country. In carrying out its responsibility, it must provide protection equal to that afforded to other Americans.

${ }^{69}$ Holcomb, "Prosecution of Non-Indians for Non-Serious Offenses,” pp. 768-69. 


\section{Chapter 6: Department of Education}

Unlike public schools, Indian schools and Indian programs across the nation are totally reliant on the level of federal funding received to ensure they meet even minimal standards. ${ }^{1}$

The federal government has a unique and continuing trust relationship with and responsibility to the Indian people for the education of Indian children. ${ }^{2}$

The U.S. Department of Education (DOEd) funds Native American individuals, governments, and organizations through various grants and contracts. ${ }^{3}$ Grants dominate, however, with only a few relatively small contracts for research and evaluation offered each fiscal year. ${ }^{4}$ Consequently, grants are the primary method DOEd uses to address the "unique educational and culturally related needs of Indian children." Because DOEd programs are designed to complement the efforts of Native American groups and those of state and local education agencies, many programs have matching fund requirements, the provisions of which depend on the applicable statute. ${ }^{6}$ The number of grants is voluminous and thus they are not within the scope of this report. In 2002, for instance, DOEd provided local education agencies and tribal schools 1,189 formula grants. ${ }^{7}$

\footnotetext{
${ }^{1}$ National Indian Education Association, “Indian Education Legislative Report, 107th Congress, Second Session,” Nov. 26, 2002, p. 4.

${ }^{2}$ U.S. Department of Education, No Child Left Behind: A Desktop Reference, Oct. 25, 2002, <http://www.ed.gov/offices/ OESE/reference/7a.html> (hereafter cited as DOEd, No Child Left Behind).

${ }^{3}$ U.S. Department of Agriculture, Federal Funding Sources for Rural Areas: Fiscal Year 2003, compiled by M. Louise Reynnells for the Rural Information Center (Beltsville, MD: National Agricultural Library, 2003), pp. 38-39, 44. Throughout this discussion the terms "Native American" and "Alaska Native" are used in lieu of DOEd's term "Indian." DOEd adheres to legislation that defines "Indian" to mean an individual who is "a member of an Indian tribe or band, as membership is defined by the tribe or band, including - any tribe or band terminated since 1940; and any tribe or band recognized by the State in which the tribe or band resides; a descendant, in the first or second degree, or an individual described above; considered by the Secretary of the Interior to be an Indian for any purpose; an Eskimo, Aleut, or other Alaska Native; or a member of an organized Indian group that received a grant under the Indian Education Act of 1988 as was in effect October 19, 1994." See U.S. Department of Education, Office of Elementary and Secondary Education, Office of Indian Education, "Programs and Responsibilities," Feb. 19, 2003, <http://www.ed.gov/offices/OESE/oie/about oie/programs.html\#fgrants>.

${ }^{4}$ U.S. Department of Education, Interrogatory Response for Native American Project, Feb. 28, 2003 (hereafter cited as DOEd, "Interrogatory Response"). In FY 1999 \$0.7 million, in FY 2000 \$1.7 million, in FY 2001 \$1.2 million, and in FY $2002 \$ 2.0$ million were approximately offered in contracts for research and evaluation.

${ }^{5}$ Victoria Vasques, director, Office of Indian Education, U.S. Department of Education, testimony before the Senate Committee on Indian Affairs, Washington, D.C., Mar. 5, 2003 (hereafter cited as Vasques testimony).

${ }^{6}$ U.S. Department of Education, Elementary and Secondary Education, FY 1998 Budget Summary, Feb. 5, 1997, $<$ http://ed.gov/offices/OUS/Budget98/BudgetSum/summary3.html>; U.S. Department of Education, Elementary and Secondary Education, FY 2003 Budget Summary, Feb. 2, 2002, <http://ed.gov/offices/OUS/Budget03/Summary/SectionII/ A.html>; U.S. Department of Education, Section II. A. Elementary and Secondary Education, Education Budget, Summary and Background Information, Fiscal Year 2004, <http://ed.gov/offices/OUS/Budget04/04summary/section2a.html > (hereafter cited as DOEd, FY 2004 Budget, Summary and Background Information); DOEd, "Interrogatory Response."

${ }^{7}$ Office of Management and Budget, Budget of the United States Government, Fiscal Year 2004, Appendix, p. 326.
} 
Instead, the focus of this chapter is the Office for Indian Education (OIE), within the Office of Elementary and Secondary Education, because despite handing only a portion of DOEd funds that benefit Native Americans, it administers federal funds for Native American students at DOEd and houses the Indian Education Program. ${ }^{8}$ OIE is also charged with managing grants, evaluating national programs, promoting communication with individuals in the field, and coordinating programs across federal agencies. This latter role is one of its most important since DOEd shares the responsibility for educating Native Americans with the Bureau of Indian Affairs and the Department of Defense, among other federal agencies. Because education funding is decentralized, agencies must coordinate their efforts to avoid wasting funds through redundancy or by letting them go unused. This chapter will demonstrate that education programs can be further compromised by inconsistent funding.

\section{Federal Education of Native Americans: 1890s-1960s}

The federal government initially educated Native American children with the goal of assimilation, a process it believed would eventually lead to the extinction of indigenous communities residing within the boundaries of the United States as Native children were acculturated in Euro-American society. ${ }^{9}$ The goal was to convert young Native Americans into "white men," with future generations naturally following their lead since Western European-based society was "inherently superior" to tribal society. ${ }^{10}$ If extinction did not occur, adherents believed, at the very least Indian identity would be suppressed. ${ }^{11}$ One of the most outspoken proponents of these views was Colonel Richard Henry Pratt, a leader in the late-1800s movement to educate Native Americans based on a Western European model and founder of the Carlisle Indian School in Pennsylvania. ${ }^{12}$ The goal of educating "Indians," in Colonel Pratt's view, was to "Kill the Indian, save the Man."13 Carlisle Indian School and 24 other such schools were established throughout the United States in the 1890s to provide Native Americans a more "fulfilling" existence. ${ }^{14}$ These schools perhaps best exemplified the federal government's objective in educating Native Americans: prevent them from speaking their language, practicing their customs, and wearing traditional dress. ${ }^{15}$ That is, make them like "us."

\footnotetext{
${ }^{8}$ U.S. Department of Education, Office of Elementary and Secondary Education, "OESE Programs by Office," Mar. 14, 2003, <http://www.ed.gov/offices/OESE/program.html>; California School Boards Association, "American Indian Student Federal Funding," Jan. 6, 2003, <http://www.csba.org/is/am_indians/funding.htm>; U.S. Department of Education, Budget Service, "Technical Comments on the Commission's Draft Report on Funding Support for Native Americans," submitted via facsimile, July 17, 2003.

${ }^{9}$ Eric Hensen, Jonathan B. Taylor, et al., Native America at the New Millennium (Cambridge, MA: Harvard University, John F. Kennedy School of Government, Project on American Indian Economic Development, November 2002) (hereafter cited as Hensen and Taylor, Native America at the New Millennium) p. 70; University of Nebraska at Lincoln, "A Brief History of Education for Native Americans," UNL Today, <http://www.unl.edu/cci861/webpages/dshafer/dshafer5.html > (hereafter cited as UNL, "A Brief History"); Elizabeth Hope Styron, "Native American Education: Documents from the 19th Century," May 1997, <http://www.duke.edu/-ehs1/education> (hereafter cited as Styron, "Native American Education").

${ }^{10}$ UNL, "A Brief History"; Styron, "Native American Education." Indigenous societies throughout the world were viewed, and still are by some, as a monolithic entity with any differences between them being the result of, for example, environmental factors. The term "tribal" was, and is, used to describe those indigenous societies organized beyond the band level but not at the chiefdom level.

${ }^{11}$ Hensen and Taylor, Native America at the New Millennium, p. 70.

${ }^{12}$ UNL, "A Brief History"; Styron, "Native American Education."

${ }^{13}$ Styron, "Native American Education."

${ }^{14}$ Hensen and Taylor, Native America at the New Millennium, p. 70; UNL, "A Brief History."

${ }^{15}$ Hensen and Taylor, Native America at the New Millennium, p. 70.
} 
Colonel Pratt had several rules for students attending Carlisle. All had to wear uniforms, give up traditional foods, and speak English only, and boys had to keep their hair short. Students were also assigned new, non-Indian names. ${ }^{16}$ Although not all the schools subscribed to Colonel Pratt's ideals, the majority did require students to surrender their indigenous religions and adopt Christianity. ${ }^{17}$

Equal educational opportunity was not among the goals in the effort to assimilate Native Americans into Euro-American society. Unlike white students (who were taught reading, writing, and mathematics), Native American students were educated in trades, such as blacksmithing, cooking, and farming. ${ }^{18}$ As one researcher argued, assimilation meant that Native American children would shoe the horses and cook the meals of white people. Even these minor expectations by Euro-Americans, however, rarely materialized. Racism typically prevented graduates of these schools from gaining acceptance in white society. ${ }^{19}$

After this initial phase of Indian education ended, in the late 1920s, the education of Native Americans took on a more supportive role. Through the late 1930s, Native Americans were educated in an environment more accepting of their beliefs. This was best exemplified by the acceptance of indigenous religions within the schools; no longer was Christianity forced upon Native Americans. ${ }^{20}$ The 1940s saw the return of assimilationist policies, culminating in the policy of termination under the Eisenhower administration during the $1950 \mathrm{~s} .{ }^{21}$ Termination policy was the federal government's effort to end its special relationship with Native Americans, as previously discussed in this report, and force them to assimilate into the larger society. ${ }^{22}$ Native American education during this period was largely forgotten by Euro-American society, with the result that it deteriorated across all areas. ${ }^{23}$

The 1960s saw a revitalization of Native American education as tribal members took the lead in forcing the federal government and the educational establishment to provide their children a quality education. From the 1960s on, the federal government has become increasingly aware that the education of Native Americans must incorporate indigenous perspectives if it is to succeed. Success also demands that Native Americans have an active voice in the education of their children. ${ }^{24}$ These changes have been primarily initiated by Native Americans tired of the status quo and determined to see their communities awaken a vibrancy that has been dormant far too long. ${ }^{25}$

\section{The Education of Native American Students Today}

Native American children inhabit the poorest segment of society in the United States, a situation that hinders their efforts to obtain an education. This poverty extends to the value society places on individuals who educate Native American students. Individuals working in Indian education are typically

\footnotetext{
${ }^{16}$ UNL, "A Brief History."

${ }^{17}$ Ibid.

${ }^{18}$ Ibid. Styron, "Native American Education."

${ }^{19}$ Styron, "Native American Education."

${ }^{20}$ Ibid.

${ }^{21}$ George Pierre Castile, "To Show Heart: Native American Self-Determination and Federal Indian Policy, 1960-1975," June 6, 1998, <http://www.uapress.arizona.edu/samples/sam1171.htm> (hereafter cited as Castile, "To Show Heart"); Styron, "Native American Education."

${ }^{22}$ Castile, "To Show Heart."

${ }^{23}$ Styron, "Native American Education."

${ }^{24}$ Hensen and Taylor, Native America at the New Millennium, p. 70; Styron, "Native American Education."

${ }^{25}$ Hensen and Taylor, Native America at the New Millennium, p. 71.
} 
underpaid in comparison to colleagues teaching non-indigenous children. ${ }^{26}$ In the $1996-1997$ school year, for instance, tribal college full-time faculty averaged $\$ 23,964$ on nine- or 10-month contracts. Full-time faculty at non-tribal two-year institutions averaged $\$ 43,730$ for the same period of work, with faculty at all public institutions in the United States averaging $\$ 49,855 .^{27}$ These individuals face numerous other obstacles, such as professional isolation and substandard physical facilities. ${ }^{28}$ These factors, and many others, such as the absence of state assistance for Indian education, lower the quality of education afforded Native Americans relative to non-indigenous students and foster a continuous violation of their civil rights. ${ }^{29}$ Current conditions pose difficult challenges for the education of Native American students. National Assessment of Educational Progress test results reveal that fourth-grade American Indian and Alaska Native students score lower than other groups in basic levels of reading, math, and history. ${ }^{30}$

\section{School Dropout Disparities}

The most recent studies indicate that Native American students have higher dropout rates than nonNative students. ${ }^{31}$ In the last decade, only 66 percent of Native American students graduated from high school, compared with 75 percent of the general population. ${ }^{32}$ The Commission's Montana Advisory Committee studied Native American education in Montana and revealed that a decade earlier, only 23 percent of Native Americans in the state completed high school, compared with 51 percent of the general state population. In the 1994-1995 school year, Native American students dropped out of Montana high schools at a rate of 10.4 percent, 3.6 times more often than white students. In grades seven and eight, Native American students dropped out of Montana schools at a rate five times greater than their white counterparts. ${ }^{33}$ Taking a broader perspective, Native American students account for 3 percent of all primary and secondary dropouts nationwide despite being approximately only 1 percent of these students. ${ }^{34}$

\section{Cultural Identity}

Dropout rates among Native American students are high because, among other reasons, their civil rights and cultural identities are often at risk in the educational environment. Research shows that Native American students experience difficulty maintaining rapport with teachers and establishing relationships with other students; feelings of isolation; racist threats; and frequent suspension. ${ }^{35}$

\footnotetext{
${ }^{26}$ Ibid.

${ }^{27}$ American Indian Higher Education Consortium, the Institute for Higher Education Policy, "Tribal Colleges: An Introduction," February 1999, pp. F-1-F-2.

${ }^{28}$ Hensen and Taylor, Native America at the New Millennium, p. 71.

${ }^{29}$ Montana Advisory Committee to the U.S. Commission on Civil Rights, Equal Educational Opportunity for Native American Students in Montana Public Schools, July 2001, pp. 1, 22 (hereafter cited as Montana Advisory Committee, Equal Educational Opportunity).

${ }^{30}$ DOEd, No Child Left Behind.

${ }^{31}$ Ardy Sixkiller Clarke, "Social and Emotional Distress Among American Indian and Alaska Native Students: Research Findings," Special Edition, ERIC Digest, January 2002, <http://www.indianeduresearch.net/edorc01-11.htm> (hereafter cited as Clarke, "American Indian and Alaska Native Students").

${ }^{32}$ DOEd, No Child Left Behind.

${ }^{33}$ Montana Advisory Committee, Equal Educational Opportunity, pp. 4, 16.

${ }^{34}$ Hensen and Taylor, Native America at the New Millennium, p. 73.

${ }^{35}$ Clarke, "American Indian and Alaska Native Students."
} 
These sentiments were echoed at a community forum held by the Commission's Montana Advisory Committee, where Native Americans attributed high dropout rates to irrelevant curricula, discriminatory practices, and insensitive teachers and administrators. ${ }^{36}$ These circumstances arise in environments that do not uphold the education rights of Native American students or recognize their cultural backgrounds, instead allowing miscommunication and confrontation leading to hostility, alienation, and dropping out. ${ }^{37}$

Conversely, students are more likely to thrive in environments that support their cultural identities while introducing different ideas. ${ }^{38}$ The importance of such environments cannot be overstated. Such programs motivate students, support improved academic performance, promote a positive sense of identity and self, stimulate favorable attitudes about school and others, and earn the support and positive perception of the community toward the school. ${ }^{39}$ Only recently have school districts in significant numbers across the United States begun developing plans for incorporating Native cultures into school curricula. The Commission expects that such efforts, when implemented, will reduce the civil rights violations of Native American students.

\section{Community Involvement}

Community responsibility for and ownership of schools are crucial for creating a positive learning environment that respects students' civil and educational rights. ${ }^{40}$ For Native Americans to have a stronger impact on the education of their children, tribal communities must be provided adequate funding. ${ }^{41}$ Yet, funding for DOEd's Native American programs has frequently hindered tribal and DOEd efforts to create effective educational environments supportive of Native American students. The proposed 2004 budget, for example, does not provide the necessary funding to meet the requirements of the No Child Left Behind Act of 2001 throughout the United States, but especially in Indian Country. ${ }^{42}$ Native Americans have frequently faced similar funding shortfalls for the education of their children. Inadequately funding Native American education programs will diminish, if not undo, the progress that has been made. ${ }^{43}$

\section{DOEd Funding of Native American Programs}

These observations about the educational conditions of Native American students call for an increased commitment by the federal government, but it has sidestepped its obligations by failing to provide the necessary resources. The amount of discretionary funds appropriated for OIE from 1998

\footnotetext{
${ }^{36}$ Montana Advisory Committee, Equal Educational Opportunity, p. 22.

${ }^{37}$ Clarke, "American Indian and Alaska Native Students."

38 Ibid.

${ }^{39}$ William G. Demmert Jr., "Improving Academic Performance Among Native American Students: A Review of the Research Literature," ERIC, Clearinghouse on Rural Education and Small Schools, December 2001, pp. 42-43.

${ }^{40}$ Ibid. John W. Tippeconnic III, "Editorial . . . On BIA Education,” Journal of American Indian Education, vol. 35, no. 1 (October 1995), <http://jaie.asu.edu/v35/V35S1edi.htm>.

${ }^{41}$ Richard St. Germaine, "Bureau Schools Adopt Goals 2000," Journal of American Indian Education, vol. 35 , no. 1 (October 1995), <http://jaie.asu.edu/v35/V35S1bur.htm>.

${ }^{42}$ No Child Left Behind Act of 2001, Pub. L. No. 107-110, 115 Stat. 1425 (codified as amended in 20 U.S.C.A. $§ 7231$ (Law. Co-op. 2003)); David Melmer, "Cuts Threaten Education and Clean Water for S.D. Reservation," Indian Country Today, Feb. 18, 2003, <http://www.indiancountry.com/?1045581087>.

${ }^{43}$ Montana Advisory Committee, Equal Educational Opportunity, p. 7.
} 
through 2003 averaged \$93.9 million per year (see tables 6.1A and 6.3). Table 6.1B illustrates the percentage of DOEd discretionary funds allocated to OIE between 1998 and 2003. Over this period, OIE received no more than 0.3 percent of DOEd's discretionary funds (see table 6.1B). DOEd's discretionary funds increased much more substantially between 2001 and 2003 than did OIE's share of these funds (see tables 6.1A and 6.1B) ${ }^{44}$ Prior to 1999, the amount appropriated for each fiscal year included program administration costs. In 1998, the final year program administration costs were included in funding amounts, administrative costs were $\$ 2.8$ million or 5 percent of total OIE funding. ${ }^{45}$ When adjusted for inflation, OIE's budget increased 76.2 percent from 1998 to 2003, not 94.2 percent as appropriations would indicate. ${ }^{46}$

Over the last few decades OIE has undergone several funding cuts, and in many years its budget has failed to account for inflation. ${ }^{47}$ Since 1980 , when program funding was at its highest level, OIE has been challenged by the responsibility to provide education for Native Americans without the necessary resources. During the 1980s, extensive cuts in DOEd educational appropriations further hindered Native American education efforts. For example, DOEd cuts forced the Lummi to seek funding from BIA to continue successful educational efforts begun in the $1970 \mathrm{~s} .{ }^{48}$ Consequently, BIA resources intended for other areas had to be redirected to education.

\footnotetext{
${ }^{44}$ DOEd, "Interrogatory Response," updated, July 17, 2003; Office of Management and Budget, Budget of the United States Government, Fiscal Year 2002, Budget, table S-6, p. 228 (hereafter cited as OMB, FY 2002 Budget); Office of Management and Budget, Budget of the United States Government, Fiscal Year 2003, Budget, tables S-6 and S-7, pp. 400-01 (hereafter cited as OMB, FY 2003 Budget); Office of Management and Budget, Budget of the United States Government, Fiscal Year 2004, Budget, tables S-6 and S-7, pp. 316-17 (hereafter cited as OMB, FY 2004 Budget).

${ }^{45}$ U.S. Department of Education, Budget Office, "Education Department Budget History Table: FY 1980_Present," Mar. 5, 2003, <http://www.ed.gov/offices/OUS/BudgetHistory/index.html> (hereafter cited as DOEd, "Budget History"); U.S. Department of Education, "Section A-Elementary and Secondary Education," FY 2000 Budget Summary, Feb. 9, 1999, $<$ http://ed.gov/offices/OUS/Budget00/BudgetSumm/sum-a.html>; U.S. Department of Education, Fiscal Year 2000 Budget, Summary and Background Information," Sept. 28, 2001, <http:/www.ed.gov/offices/OUS/Budget00>. The average amount of funding from 1998 through 2004 excludes program administration costs.

${ }^{46}$ OMB, FY 2000 Budget, Appendix, pp. 351-52; OMB, FY 2001 Budget, Appendix, pp. 353-54; OMB, FY 2002 Budget, Appendix, pp. 352-53; OMB, FY 2003 Budget, Appendix, p. 352; OMB, FY 2004 Budget, Appendix, pp. 326-27; OMB, FY 2002 Budget, table S-6, p. 228; OMB, FY 2003 Budget, tables S-6 and S-7, pp. 400-01; OMB, FY 2004 Budget, tables S-6 and S-7, pp. 316-17; DOEd, "Responses to Follow-Up Questions to Interrogatory Response"; U.S. Department of Education, Budget Office, "Native American Information, Appendix A, Department of Education, Indian Education Program," submitted via e-mail, Feb. 26, 2003 (hereafter cited as DOEd, Native American Information, Appendix A).

${ }^{47}$ Michael Cohen, assistant secretary, Office of Elementary and Secondary Education, U.S. Department of Education, testimony before the Senate Committee on Indian Affairs, Washington, D.C., Feb. 23, 2000 (hereafter cited as Cohen testimony).

${ }^{48}$ Susanna A. Hayes, "Educational Innovation at Lummi," Journal of American Indian Education, vol. 29, no. 31 (May 1990), <http://jaie.asu.edu/v29/V29S3edi.htm>. The Lummi discussed in this journal article are located in northwest Washington State.
} 
TABLE 6.1A

DOEd Appropriations for Office of Indian Education, FY 1998-2004 (in millions of dollars)

\begin{tabular}{|c|c|c|c|c|c|c|c|}
\hline & 1998* & 1999 & 2000 & 2001 & 2002 & 2003 & $2004^{* *}$ \\
\hline Office of Indian Education & 62.6 & 66.0 & 77.0 & 115.5 & 120.4 & 121.6 & 122.4 \\
\hline Year-to-year growth & & & & & & & \\
\hline & & \multicolumn{2}{|c|}{$16.7 \%$} & \multicolumn{2}{|c|}{$4.2 \%$} & \multicolumn{2}{|c|}{$0.7 \%$} \\
\hline
\end{tabular}

\section{TABLE 6.1B}

Office of Indian Education Program Funds as Percentage of DOEd Discretionary Funds, FY 1998-2004 (in billions of dollars)

\begin{tabular}{|c|c|c|c|c|c|c|c|}
\hline & 1998 & 1999 & 2000 & 2001 & 2002 & 2003 & $2004^{* *}$ \\
\hline DOEd discretionary funds & 29.8 & 28.8 & 29.4 & 40.1 & 48.5 & 53.1 & 53.1 \\
\hline Year-to-year growth & \multicolumn{2}{|c|}{$(3.4 \%)$} & \multicolumn{2}{|c|}{$36.4 \%$} & \multicolumn{2}{|c|}{$9.5 \%$} & \\
\hline & & \multicolumn{2}{|c|}{$2.1 \%$} & \multicolumn{2}{|c|}{$21.0 \%$} & \multicolumn{2}{|c|}{$0 \%$} \\
\hline $\begin{array}{l}\text { Percent of discretionary funds } \\
\text { for OIE }\end{array}$ & $0.2 \%$ & $0.2 \%$ & $0.3 \%$ & $0.3 \%$ & $0.2 \%$ & $0.2 \%$ & $0.2 \%$ \\
\hline
\end{tabular}

* Includes program administration costs.

${ }^{* *}$ Requested amount.

Sources: U.S. Department of Education, Budget Office, "Native American Information, Appendix A, Department of Education, Indian Education Program," submitted via e-mail, Feb. 26, 2003, updated, July 17, 2003; Office of Management and Budget, Budget of the United States Government, Fiscal Years 2002-2004, tables S-6 and S-7.

OIE's subprograms have suffered from inconsistent funding throughout the period reviewed here; in fact, at no time has OIE received full funding, and many subprograms have never been funded. ${ }^{49}$ In 1998, the President's budget did not request funds for any of the subprograms listed in table 6.2. In fact, only two subprograms received funding between 1998 and 2003 (see table 6.2). ${ }^{50}$ The President's 2004 budget request continues a trend of requesting only partial funding for several reauthorized initiatives within these programs. ${ }^{51}$

If authorized, the 2004 DOEd budget will provide a per pupil payment of $\$ 206$ for the approximately 471,000 Native American students funded by the federal government. This is a $\$ 3$ reduction from the 2003 per pupil payment request of \$209 that supported 465,000 Native American students. ${ }^{52}$ The 2004 request represents a $\$ 6$ increase over 2001 per pupil expenditures and $\$ 72$ more than in $2000 .^{53}$

\footnotetext{
49 OIE subprograms are specific grants contained within programs. For example, Special Programs for Indian Children contains a grant for Educational Services for Indian Children and a grant for Professional Development, among others. Full funding means that all subprograms within a program have been funded.

${ }^{50}$ National Indian Education Association, "U.S. Department of Education, Office of Indian Education, Indian Education Funding, Fiscal Years 1994-2003 Request” (hereafter cited as NIEA, “Indian Education Funding, FY 1994-2003”).

${ }^{51}$ NIEA, "Indian Education Funding, FY 1994-2003"; John W. Cheek, executive director, National Indian Education Association, testimony before the Senate Committee on Indian Affairs, Washington, D.C., Feb. 26,2003 (hereafter cited as Cheek testimony, 2003); Allen testimony, Feb. 24, 1999.

${ }^{52}$ Vasques testimony; Thomas M. Corwin, deputy assistant secretary, Office of Elementary and Secondary Education, U.S. Department of Education, testimony before the Senate Committee on Indian Affairs, Washington, D.C., Mar. 5, 2002.

${ }^{53}$ Cohen testimony.
} 
TABLE 6.2

Office of Indian Education Subprograms Not Funded at Some Point During FY 1998-2004

(in millions of dollars)

\begin{tabular}{|c|c|c|c|c|c|c|c|}
\hline & 1998 & 1999 & 2000 & 2001 & 2002 & 2003 & $2004^{*}$ \\
\hline \multicolumn{8}{|l|}{ Special Programs for Indian Children } \\
\hline Educational Services for Indian Children & 0 & 1.3 & 1.3 & 2.4 & 2.4 & 13 & 13 \\
\hline Planning, Pilot and Demonstration & 0 & 0 & 0 & 0 & 0 & 0 & 0 \\
\hline Indian Fellowships & 0 & 0 & 0 & 0 & 0 & 0 & 0 \\
\hline Educational Professional Development & 0 & 0 & 0 & 0 & 0 & 0 & 0 \\
\hline Gifted and Talented Programs & 0 & 0 & 0 & 0 & 0 & 0 & 0 \\
\hline $\begin{array}{l}\text { Grants to Tribes for Education Administration, } \\
\text { Planning and Development }\end{array}$ & 0 & 0 & 0 & 0 & 0 & 0 & 0 \\
\hline Subtotal & 0 & 1.3 & 1.3 & 2.4 & 2.4 & 13 & 13 \\
\hline \multicolumn{8}{|l|}{ National Activities } \\
\hline Statistics and Assessment & & 0.7 & 1.7 & 2.7 & 3.2 & 5.2 & 5.2 \\
\hline Subtotal & 0 & 0.7 & 1.7 & 2.7 & 3.2 & 5.2 & 5.2 \\
\hline Total & 0 & 2 & 3 & 5.1 & 5.6 & 18.2 & 18.2 \\
\hline
\end{tabular}

${ }^{*}$ Requested amount.

Sources: Department of Education, Office of Indian Education, "Indian Education Funding, Fiscal Years 1994-2003 Request"; W. Ron Allen, testimony before the Committee on Indian Affairs, United States Senate, hearing, Washington, D.C., Feb. 25, 1998; W. Ron Allen, testimony before the Committee on Indian Affairs, United States Senate, hearing, Washington, D.C., Feb. 24, 1999; John W. Cheek, testimony before the Committee on Indian Affairs, United States Senate, hearing, Washington, D.C., Feb. 26, 2003.

TABLE 6.3

Comparison of DOEd Discretionary Budget and Office of Indian Education Funding in Constant 2003 Dollars, FY 1998-2004

\begin{tabular}{|c|c|c|c|c|c|c|c|}
\hline & 1998 & 1999 & 2000 & 2001 & 2002 & 2003 & $2004^{*}$ \\
\hline DOEd (in billions) & 29.8 & 28.8 & 29.4 & 40.1 & 48.5 & 53.1 & 53.1 \\
\hline In constant 2003 dollars & 32.9 & 31.3 & 31.1 & 41.5 & 49.4 & 53.1 & 52.1 \\
\hline Average annual funding, 1998-2003 & \multicolumn{7}{|c|}{$\$ 38.3$ billion } \\
\hline $\begin{array}{l}\text { Average annual funding in constant } 2003 \\
\text { dollars, 1998-2003 }\end{array}$ & \multicolumn{7}{|c|}{$\$ 39.9$ billion } \\
\hline Change, 1998-2003 & \multicolumn{7}{|c|}{$\$ 23.3$ billion or $78.2 \%$} \\
\hline Change in constant 2003 dollars, 1998-2003 & \multicolumn{7}{|c|}{$\$ 20.2$ billion or $61.4 \%$} \\
\hline Office of Indian Education (in millions) & $62.6^{* *}$ & 66.0 & 77.0 & 115.5 & 120.4 & 121.6 & 122.4 \\
\hline In constant 2003 dollars & 69.0 & 71.6 & 81.5 & 119.5 & 122.7 & 121.6 & 120.1 \\
\hline Average annual funding, 1998-2003 & \multicolumn{7}{|c|}{$\$ 93.9$ million } \\
\hline $\begin{array}{l}\text { Average annual funding in constant } 2003 \\
\text { dollars, 1998-2003 }\end{array}$ & \multicolumn{7}{|c|}{$\$ 97.7$ million } \\
\hline Change, 1998-2003 & \multicolumn{7}{|c|}{$\$ 59.0$ million or $94.2 \%$} \\
\hline Change in constant 2003 dollars, 1998-2003 & \multicolumn{7}{|c|}{$\$ 52.6$ million or $76.2 \%$} \\
\hline
\end{tabular}

* Requested amount.

** Includes approximately $\$ 2.8$ in program administration costs.

Sources: Office of Management and Budget, Budget of the United States Government, Fiscal Years 2000-2004, Department of Education, Office of Elementary and Secondary Education, Federal Funds, Indian Education; Office of Management and Budget, Budget of the United States Government, Fiscal Years 2002-2004, Budget, tables S-6 and S-7; Department of Education Response to the U.S. Commission on Civil Rights' Follow-Up Questions for Native American Project, Mar. 21, 2003; U.S. Department of Education, Budget Office, "Native American Information, Appendix A, Department of Education, Indian Education Program," submitted via e-mail, Feb. 26, 2003, updated, July 17, 2003. 


\section{Unmet Education Needs}

The 2002 DOEd budget provided local education agencies \$200 per Native American pupil. ${ }^{54}$ The National Indian Education Association (NIEA) estimated that at least $\$ 250$ per pupil was required, an increase of 25 percent above the budgeted amount, especially since the 2000 census revealed a rise in the number of Native American students. In reality, however, an extra $\$ 50$ per pupil would have only minimally addressed the unmet education needs of Native American students because funding has long been and continues to be inadequate. For instance, NIEA states that another $\$ 10$ million or 50 percent more is required for three existing, but unfunded, subprograms in Special Programs for Indian Children (see table 6.2). ${ }^{55}$ The federal government's failure to fund Native American education adequately is exemplified by the Navajo Nation, whose BIA schools received a per pupil payment that was 30 percent below the national average in $1999 .{ }^{56}$

The Navajo situation demonstrates that BIA education programs have also failed to keep up with education programs nationally. DOEd provides funds to BIA schools based on an authorized percentage set-aside and transfers funds to BIA for the benefit of students in those schools. ${ }^{57}$ These funds are set aside at DOEd from funding for programs available to all students, whether Native American or not. ${ }^{58}$ The 2003 budget provided a 1.5 percent funding increase for BIA education programs, significantly less than the funding increase for DOEd programs available to all populations. Because 1.5 percent was insufficient to cover pay increases, program dollars were directed toward that end. Consequently, the dollars available for program purposes decreased. ${ }^{59}$ NIEA states that pay increases are necessary to attract and retain highly qualified individuals to work with Native American students or any students; thus, providing sufficient funds for pay increases is essential. ${ }^{60}$ Moreover, as new schools enter the BIA system each year, funding becomes more thinly spread and unmet needs multiply. ${ }^{61}$ Finally, education programs targeting Native American students are being inadequately funded through BIA, with BIA and tribally operated schools spending roughly 50 to 60 per-

\footnotetext{
${ }^{54}$ Grants to local education agencies, along with Special Programs for Indian Children and National Activities, compose OIE programs. Grants to local education agencies, targeted to the public and BIA elementary and secondary schools, provide the majority of funding for Native American students supplied by OIE. In 2002, for example, this program provided $\$ 97$ million to local education agencies. Special Programs for Indian Children is the second largest grant program. Between 1998 and 2003, it averaged \$12.7 million annually. Finally, National Activities, which annually provides a few small contracts for research and evaluation, has the smallest budget. In 2002, for example, its grant budget was \$3 million.

${ }^{55}$ National Indian Education Association, "National Indian Education Association, 32nd Annual Convention, Billings, Montana, Indian Education Legislative Report, 107th Congress, 1st Session, 2001, p. 14 (hereafter cited as NIEA, "32nd Annual Convention").

${ }^{56}$ Faye Blueeyes, director of facilities, Shiprock Alternative Schools Inc., testimony before the House Subcommittee on Early Childhood, Youth and Families of the Committee on Education and the Workforce, Washington, D.C., July 20, 1999, $<$ http://commdocs.house.gov/committees/edu/hedcew6-60.000/hedcew6-60.htm> (hereafter cited as Blueeyes testimony).

${ }^{57}$ Cheek testimony, 2003.

${ }^{58}$ DOEd, "Responses to Follow-Up Questions to Interrogatory Response"; U.S. Department of Education, "Estimate of Department of Education Funds Benefiting Indians," Oct. 28, 2002, <http://www.ed.gov/offices/OESE/oie/benefit.html>.

${ }^{59}$ National Indian Education Association, "Statement of the National Indian Education Association, Submitted to the Senate Interior Appropriations Subcommittee on the President's Fiscal Year 2003 Budget for the Department of Interior, Bureau of Indian Affairs," Apr. 5, 2002, p. 2 (hereafter cited as NIEA, Statement of the NIEA).

${ }^{60}$ NIEA, “32nd Annual Convention,” p. 6.

${ }^{61}$ Blueeyes testimony.
} 
cent of funds for instruction that public schools spend because the rest must be used for the upkeep of school buildings. ${ }^{62}$

There is also concern that education funds for Native Americans do not always reach the students they are intended to serve. While the set-aside for BIA schools presumably is spent on Native students, it is not clear that this is the case with grants to local education agencies. Most Native Americans are educated in non-tribal public schools, not BIA schools; thus, a large share of education funding does not flow directly to Native students. School districts may or may not be in compliance with the requirement that Indian education funds be used to supplement, not supplant, other resources.

\section{School Administration}

According to NIEA, Special Programs for Indian Children should be allocated \$1 million more than the 2004 budget proposal to fund the American Indian Administrator Corps (a program supporting the recruitment, training, and in-service professional development of 500 American Indians and Alaska Natives to become effective administrators in schools with high populations of Native American students). Native American school administrators, as others, require training in how to motivate, encourage, mentor, and support their students. ${ }^{63}$ Native Americans, when they occupy positions as school administrators, not only facilitate communication between Native American students and school officials, but also can be role models.

\section{Special Education}

The lack of funds for Special Programs for Indian Adults (a program assisting Native American adults who have few if any education opportunities) illustrates that older Native American students have fared no better than younger Native American students in many respects. As of 2002, Special Programs for Indian Adults had not received funding for seven years. This program was last funded in 1995, when it was allocated $\$ 5.4$ million. ${ }^{64}$ Native Americans who depend on this program to prepare for a high school equivalency examination, for example, have been unable to reach this goal. NIEA requested that this program at least be funded at that same amount for 2002, although that request was not granted. For 2004, NIEA recommends at least $\$ 1$ million be provided for this subprogram, 81.5 percent less than it requested just two years earlier. ${ }^{65}$ This reduced request is not a result of the federal government having met the education needs of Native Americans, but a concession that any funding is better than none.

\footnotetext{
${ }^{62}$ Joe Christie, acting director, Office of Indian Education Programs, Bureau of Indian Affairs, testimony before the House Subcommittee on Early Childhood, Youth and Families of the Committee on Education and the Workforce, Washington, D.C., July 20, 1999, <http://commdocs.house.gov/committees/edu/hedcew6-60.000/hedcew6-60.htm> (hereafter cited as Christie testimony).

${ }^{63}$ Cheek testimony, 2003. The Commission did not find information on the current number of Native American school administrators.

${ }^{64}$ NIEA, "32nd Annual Convention," p. 14; Cheek testimony, 2003; U.S. Department of Education, "Archived Information," Biennial Evaluation Report-FY 93-94, Chapter 114, Special Programs for Indian Adults-Subpart 3 (CFDA No. 84.062); "Archived Information," Indian Education-Special Programs Relating to Adult Education for Indian-Subpart 3 (CFDA No. 84.060).

${ }^{65}$ NIEA, “32nd Annual Convention,” p. 14; Cheek testimony, 2003.
} 


\section{Higher Education}

DOEd also targets Native American students through other programs, including (1) the Tribally Controlled Postsecondary Vocational and Technical Institutions Program, which provides competitive grants for the operation and improvement of eligible institutions to ensure continued and expanded opportunities for Indian students, under the direction of the Office of Vocational and Adult Education; and (2) the Strengthening Tribally Controlled Colleges and Universities Program, which provides grants to eligible institutions of higher education to enable them to improve their academic quality, institutional management, and fiscal stability, and increase their self-sufficiency. Both are administered by the Office of Postsecondary Education. ${ }^{66}$ These programs fund 30 tribally controlled postsecondary vocational institutions and 34 tribal colleges and universities, each having campuses in 12 states. ${ }^{67}$ Funding for these programs increased from 1998 through 2003 . However, both programs face a decrease in 2004 from 2003 levels (see table 6.4). ${ }^{68}$

The conditions under which tribal institutions must educate Native Americans are constrained by the lack of a tax base to support them. Native American communities are not permitted to levy taxes to support higher education because they are located on federal trust lands. By contrast, property taxes are an important revenue source for non-Native community colleges. Tribally controlled colleges and universities receive just under $\$ 3,000$ annually per student, less than half of the amount annually provided per student to other community colleges, and do not have access to other state and local dollars, exacerbating the situation. ${ }^{69}$

\section{TABLE 6.4}

DOEd Funding of Select Native American Programs, FY 1998-2004 (in millions of dollars)

\begin{tabular}{|c|c|c|c|c|c|c|c|}
\hline & 1998 & 1999 & 2000 & 2001 & 2002 & 2003* & $2004^{* *}$ \\
\hline $\begin{array}{l}\text { Tribally Controlled Postsecondary Vocational } \\
\text { Institutions Program }\end{array}$ & 3.1 & 4.1 & 4.6 & 5.6 & 6.5 & 7.0 & 6.5 \\
\hline $\begin{array}{l}\text { Strengthening Tribally Controlled Colleges and } \\
\text { Universities (Title III Institutional Aid) }\end{array}$ & -- & 3.0 & 6.0 & 15.0 & 17.5 & 22.9 & 19.0 \\
\hline
\end{tabular}

Funding for these programs has always been insufficient. The $2003 \$ 22.9$ million funding level for tribally controlled colleges and universities, for example, fell far short of the \$38 million to \$42 mil-

\footnotetext{
${ }^{66}$ U.S. Department of Education, Office of Vocational and Adult Education, "Tribally Controlled Postsecondary Vocational Institutions Program,” Feb. 21, 2002, <http://www.ed.gov/offices/OVAE/CTE/tcpvi.html>; Office of Postsecondary Education, "Title III Part A Programs," Institutional Development and Undergraduate Education Programs, June 23, 2003, <http://www.ed.gov/offices/OPE/HEP/idues/title3a.html>. Although other DOEd funding programs specifically target Native Americans, the amount provided to Native Americans is not generally identified. Accordingly, the Commission is unable to learn even approximate amounts for these programs in three of the fiscal years analyzed in this report. The DOEd budget office also informed the Commission that these data, including some painstakingly assembled by the Commission from various sources, are not available from DOEd. See DOEd, "Interrogatory Response."

${ }^{67}$ Ron McNeil, chairman, President's Board of Advisors on Tribal Colleges and Universities, and president, Sitting Bull College, Fort Yates, North Dakota, testimony before the Senate Committee on Indian Affairs, Washington, D.C., Feb. 26, 2003 (hereafter cited as McNeil testimony); National Center for Education Statistics, "Digest of Education Statistics, 2001, Chapter 3. Postsecondary Education,” Mar. 30, 2003, <http://nces.ed.gov/pubs2002/digest2001/tables/dt220.asp>.

${ }^{68}$ McNeil testimony.

${ }^{69}$ Hensen and Taylor, Native America at the New Millennium, p. 76.
} 
lion NIEA estimated was needed. ${ }^{70}$ NIEA's minimally acceptable funding level is 66 percent above the funding provided by DOEd. Tribal colleges and universities remain the most poorly funded institutions of higher education in the country, a situation compounded by the failure of most state and local governments to provide funds for non-Indian students attending these institutions, thus further stretching their limited resources. ${ }^{71}$ This is no small matter, nor are the resources used for these students insignificant, as approximately 20 percent of students attending these institutions are not Native American. ${ }^{72}$ Consequently, despite the recent funding increases, tribally controlled institutions must constantly struggle to meet their mission. ${ }^{73}$ Because tribal colleges rely on federal funding to meet core operational needs, not as a supplement to other funding, adequate funding is even more critical. ${ }^{74}$

Moreover, tribal colleges educate the smallest, poorest, and most underrepresented group in higher education, a group that might otherwise not participate in higher education. This last point is especially significant in light of the fact that tribal colleges receive less federal funding per student than other colleges. The average funding level per full-time student for non-tribal community colleges was $\$ 7,000$ in 1996 . By comparison, tribal colleges received $\$ 2,900$ per full-time enrolled Native American student, or roughly 60 percent less. To make up for the lack of money caused by inadequate per student funding, tribal college tuitions are typically so high that many Native American students cannot afford them. ${ }^{75}$

According to one researcher, obtaining adequate financial resources is probably the most serious challenge for Native Americans attempting to earn a college degree. Since poverty levels among Native Americans are exceptionally high, many Native American students are unable to rely on financial assistance from their families to cover college costs. Consequently, they rely heavily on grants, loans, and work-study to cover tuition and other college-related costs. Bureaucratic hurdles and increasingly complex application procedures, coupled with unrealistic earning requirements, often mean that students do not have enough financial resources to cover costs. In the latter instance, Native American students and their families are expected to contribute a certain amount of money toward expenses. High reservation unemployment rates make this unrealistic because frequently jobs are either not available or pay very low wages. ${ }^{76}$

\section{Vocational Rehabilitation}

Set-asides for vocational rehabilitation services, that is, grants to train indigenous individuals with disabilities to prepare them for gainful employment, may be funded at $\$ 2$ million or 4.2 percent more in 2004 than in $2002 .{ }^{77}$ However, the requested 2004 amount is at the minimal level established by

\footnotetext{
${ }^{70}$ NIEA, Statement of the NIEA, p. 4.

${ }^{71}$ Hensen and Taylor, Native America at the New Millennium, p. 76; McNeil testimony. Because most tribally controlled colleges and universities are located on federal trust land, state and local governments are not obligated to fund them.

${ }^{72}$ Hensen and Taylor, Native America at the New Millennium, p. 76.

${ }^{73}$ McNeil testimony.

74 Amy Fann, “Tribal Colleges: An Overview," ERIC Digest, January 2002, <http://www.ericfacility.net/ericdigests/ ed467847.html> (hereafter cited as Fann, "Tribal Colleges").

${ }^{75}$ Fann, "Tribal Colleges."

${ }^{76}$ Deirdre A. Almeida, "Postsecondary Financial Aid for American Indians and Alaska Natives," ERIC Digest, December 2000, <http://www.ericfacility.net/ericdigets/ed438148.html $>$.

${ }^{77}$ U.S. Department of Education, Rehabilitation Services Administration, "Basic Vocational Rehabilitation Services," Apr. 10, 2002, <http://www.ed.gov/offices/OSERS/RSA/Programs/Formula/bvrs.html> (hereafter cited as DOEd/RSA, Basic
} 
Congress, exactly 1 percent. $^{78}$ This holds true for 2002 and 2003, when funding was also at 1 percent of the total fund. In 2002, the set-aside was $\$ 25.6$ million out of a total vocational rehabilitation services budget of $\$ 2.5$ billion. In 2003, the set-aside totals $\$ 26.5$ million from a budget of $\$ 2.6$ billion (see table 6.5). ${ }^{79}$

Despite increased funding, vocational rehabilitation needs among Native Americans are not being met. According to the Consortia of Administrators for Native American Rehabilitation (CANAR), of the 14 tribes or consortia of tribes that applied for services under this program in 2001, only five received funds before DOEd resources ran out. Nine tribes were unable to provide tribal members with rehabilitative services because the federal government did not provide the program with sufficient funding. A year earlier, 13 tribes were denied assistance because program funding was inadequate. The number of tribes applying for funding, however, does not include all the tribes needing services. Since obtaining agency funding is so difficult, many tribes are discouraged from even applying for this program. To remedy this situation, CANAR recommends that program funding be increased 0.1 percent annually until the Native American set-aside from total program funding reaches 2 percent. ${ }^{80}$

Inadequate funding is compounded by the requirement that tribes compete for continued funding every five years. Native American groups fortunate enough to obtain funding must endure the uncertainty of the application process all over again after a 60 -month period. CANAR recommends that instead of automatically terminating funding after five years, the government base continued funding on the success of individual programs because most projects funded through the program are more than five years in duration. Moreover, many projects have not had their funding renewed even though they adhered to the provisions of the law and regulations. Another debilitating factor is the program's failure to provide cost-of-living increases. As with other education programs, vocational rehabilitation services for Native Americans fails to compensate for the annual increases due to inflation and other expenses. ${ }^{81}$

\section{Other Native American Set-Aside Programs}

DOEd also administers set-asides, funds targeted to Native American students that are incorporated into programs available to non-indigenous individuals. These programs address such areas as English language acquisition and Even Start. The English language acquisition program, for example, provides grants that support language instruction education programs for limited-English-proficient children from diverse backgrounds, including Native Americans. ${ }^{82}$ The amount designated for set-

Vocational Rehabilitation Services); DOEd, "Responses to Follow-Up Questions to Interrogatory Response"; Cheek testimony, 2003.

${ }^{78}$ DOEd, FY 2004 Budget, Summary and Background Information, Section II. B; Cheek testimony, 2003. The maximum set-aside established by Congress is 1.5 percent.

${ }^{79}$ DOEd, FY 2004 Budget, Summary and Background Information, Section II. B; DOEd/RSA, Basic Vocational Rehabilitation Services.

${ }^{80}$ Consortia of Administrators for Native American Rehabilitation, Northern Arizona University, "The CANAR 11: Proposals for Changes to the Rehabilitation Act of 1973, as Amended," December 2001, p. 1 (hereafter cited as CANAR, "Changes to the Rehabilitation Act of 1973").

${ }^{81}$ CANAR, "Changes to the Rehabilitation Act of 1973," pp. 1-2.

${ }^{82}$ Office of English Language Acquisition, "Native American and Alaska Native Children in School Program, Notice Inviting Applications for New Awards for Fiscal Year (2002)," 67 Fed. Reg. 30,883, May 8, 2002, <http://www.ed.gov/ legislation/FedRegister/announcements/2002-2/050802d.html $>$. These other backgrounds are Alaska Native, Native Hawaiian, and Native American Pacific Islander. 
asides varies in some programs from year to year. ${ }^{83}$ Funding for four of the six programs will remain the same or be less in 2004 than in 2002 and/or 2003 (see table 6.5) ${ }^{84}$ Native American set-asides for the Even Start program, which provides funds to help break the cycle of poverty and illiteracy among disadvantaged individuals, for instance, will be 48 percent less in 2004 than in 2003 or 2002, if the President's request is approved. ${ }^{85}$ In other words, in 2004 Indian tribes and tribal organizations may have to conduct their Even Start programs with roughly half the funds they currently have. ${ }^{86}$

Even Start serves a vital role in Native American communities. Among the Cherokee Nation, for example, families participating in Even Start earn less than $\$ 10,000$ annually, with roughly 35 percent headed by a single parent. A few years ago, demand for Even Start was so great among the Cherokee that 16 families had been on the program waiting list for several years. In fact, program turnover was so low that 16 of 20 participating families had been enrolled in the program for three years. Even Start has provided critically needed services among the Cherokee, including assistance for children experiencing difficulty with writing and language skills. For adult participants, academic training has been provided so that they can earn GED certificates. Support services, such as assisting families unable to pay their utility bills, have also been essential for the Cherokee. ${ }^{87}$

TABLE 6.5

DOEd Estimated Set-Asides Directly Supporting Native American Students, FY 2002-2004 (in millions of dollars)

\begin{tabular}{|c|c|c|c|}
\hline & 2002 & 2003 & 2004 \\
\hline Vocational Education & 14.8 & 14.9 & 12.5 \\
\hline Even Start & 5.0 & 5.0 & 2.6 \\
\hline Impact Aid-Disabilities & 21.2 & 21.5 & 21.7 \\
\hline Impact Aid-Construction & 9.0 & 8.9 & 9.0 \\
\hline Vocational Rehabilitation Services & 25.6 & 26.5 & 27.6 \\
\hline English Language Acquisition & 5.0 & 5.0 & 5.0 \\
\hline Total & 80.6 & 81.8 & 78.4 \\
\hline
\end{tabular}

Source: Department of Education Response to the U.S. Commission on Civil Rights' Follow-Up Questions for Native American Project, Mar. 21, 2003, updated, July 17, 2003.

\section{Conclusion}

Native American students are frequently forced to endure educational environments that violate their rights to equal educational opportunity and ignore their cultural identities. ${ }^{88}$ Consequently, Native American students drop out of high school at rates far exceeding those of the general population. ${ }^{89}$ Schools have recently begun to address these issues through the creation of educational

\footnotetext{
${ }^{83}$ DOEd, "Responses to Follow-Up Questions to Interrogatory Response."

${ }^{84}$ DOEd/RSA, Basic Vocational Rehabilitation Services; DOEd, "Responses to Follow-Up Questions to Interrogatory Response."

${ }^{85}$ National Even Start Association, "Even Start_Family Literacy Program Description,” Jan. 27, 2002, <http://www. evenstart.org/program_description.htm>.

${ }^{86}$ Vasques testimony.

${ }^{87}$ Marjorie Levin et al., National Evaluation of the Even Start Family Literacy Program: Report on Even Start Projects for Indian Tribes and Tribal Organizations (Cambridge, MA: ABT Associates Inc., 1997), pp. 10, 13, 15.

${ }^{88}$ Clarke, "American Indian and Alaska Native Students."

${ }^{89}$ DOEd, No Child Left Behind.
} 
environments sensitive to the needs of Native American students. Inadequate federal funding, however, threatens to end these efforts in their infancy. ${ }^{90}$

Disparities in funding between Native American students and the general population perpetuate and increase unmet education needs among Native Americans. BIA and tribally operated schools, generally, use roughly 50 to 60 percent of their funds for instruction that public schools spend because the rest must be used for upkeep of school buildings. ${ }^{91}$ Inadequate federal funding of Native American colleges is compounded by the lack of a tax base to support them. Specifically, Native American institutions cannot levy taxes to support higher education because they are located on federal trust land. Conversely, non-Native community colleges obtain substantial funding from property taxes. ${ }^{92}$ Because tribal colleges do not receive sufficient federal funds, tuitions are typically so high that many Native American students cannot afford them. ${ }^{93}$

The federal government's failure to fund Native American education programs sufficiently threatens tribal efforts to provide children, and all individuals seeking an education, with the necessary tools to function in a society that requires knowledge and skills to address a constantly changing and technologically demanding world. Among the funding problems inhibiting Native American education programs are:

- Since 1980, OIE's funding has undergone several funding cuts. From 1998 to 2003, its budget increased $\$ 52.6$ million or 76.2 percent when adjusted for inflation. ${ }^{94}$ Although a substantial increase by all appearances, closer examination shows that numerous subprograms have not been funded during this period, suggesting that the increase has not been enough. ${ }^{95}$

- Funding increases for DOEd Native American programs often come at the expense of other programs. For example, the 2004 budget proposal increases funding for some Native American programs, but eliminates funding for others.

\footnotetext{
${ }^{90}$ Montana Advisory Committee, Equal Educational Opportunity, p. 7.

${ }^{91}$ Christie testimony.

${ }^{92}$ Hensen and Taylor, Native America at the New Millennium, p. 76.

${ }^{93}$ Fann, "Tribal Colleges."

${ }^{94}$ OMB, FY 2000 Budget, Appendix, pp. 351-52; OMB, FY 2001 Budget, Appendix, pp. 353-54; OMB, FY 2002 Budget, Appendix, pp. 352-53; OMB, FY 2003 Budget, Appendix, p. 352; OMB, FY 2004 Budget, Appendix, pp. 326-27; OMB, FY 2002 Budget, table S-6, p. 228; OMB, FY 2003 Budget, tables S-6 and S-7, pp. 400-01; OMB, FY 2004 Budget, tables S-6 and S-7, pp. 316-17; DOEd, Native American Information, Appendix A.

${ }^{95}$ NIEA, "Indian Education Funding, FY 1994-2003."
} 


\section{Chapter 7: Department of Agriculture}

There's no real hunger on the Sioux reservation, not in the traditional sense, insists Red Gates. No one is malnourished. No one starves. But he makes this claim with a sadness in his eyes behind his purple sunglasses, because he knows that the commodities program he runs, along with Food Stamps, WIC, school breakfast and lunch programs, are the only reasons that the Standing Rock Sioux generally have enough to eat. ${ }^{1}$

The U.S. Department of Agriculture (USDA) provides assistance to Native Americans through numerous programs and services. Programs are administered through seven mission areas: (1) Natural Resources and Environment; (2) Farm and Foreign Agricultural Services; (3) Rural Development; (4) Food, Nutrition, and Consumer Services (FNCS); (5) Food Safety; (6) Research, Education, and Economics; and (7) Marketing and Regulatory Programs. ${ }^{2}$ Each mission area contains specific programs through which USDA addresses Native American needs, including economic development and nutritional needs. ${ }^{3}$ This chapter will discuss the government's obligation to fund programs, the failure of which is evident in unemployment, poverty, lack of rural and economic development, food insecurity, and hunger.

\section{USDA Funding of Native American Programs}

USDA provides financial assistance to Native Americans from a broad range of programs, almost as diverse as the programs managed by BIA (see table 7.1). For example, not only does USDA provide animal and plant inspection services, it also provides economic research and foreign agricultural services, the latter assisting Native American farmers in selling their products to foreign markets. ${ }^{4}$ USDA also joins other federal agencies in working with Native Americans. With BIA, for example, it provides extension education services on reservations and in tribal jurisdictions. ${ }^{5}$ Because USDA works with other federal agencies in assisting Native Americans, it must closely coordinate its efforts with these other agencies to avoid wasted resources.

\footnotetext{
1 Grass-Roots.Org, "Groups That Change Communities, Standing Rock Sioux Tribe Food Distribution Program," $<$ http://www.grass-roots.org/usa/stanrock.shtml $>$.

${ }^{2}$ U.S. Department of Agriculture, Office of Congressional Relations, "Guide to USDA Programs for American Indians and Alaska Natives, Rural Development," Jan. 30, 2001, <http://www.usda.gov/news/pubs/indians/open.htm> (hereafter cited as USDA, "Guide to USDA Programs for American Indians and Alaska Natives"), submitted via e-mail, Feb. $14,2003$.

${ }^{3}$ U.S. Department of Agriculture, Office of Budget and Program Analysis, "United States Department of Agriculture, Programs for Native Americans and Native American Institutions, Program Level," submitted via e-mail, Feb. 14, 2003 (hereafter cited as USDA, "Programs for Native Americans").

${ }^{4}$ U.S. Department of Agriculture, Foreign Agricultural Service, "Building Markets Overseas,” Apr. 28, 2003, <http:// www.fas.usda.gov/aboutfas.html>.

${ }^{5}$ U.S. Department of Agriculture, Cooperative State Research, Education and Extension Service, "Background," Mar. 7, 2002, <http://www.reeusda.gov/nre/EIRP/eirp.htm>.
} 
TABLE 7.1

USDA Funding of Programs Targeting Native Americans and Native American Institutions, FY 1999-2004 (in thousands of dollars)

\begin{tabular}{|c|c|c|c|c|c|c|}
\hline & 1999 & 2000 & 2001 & 2002 & 2003 & 2004* \\
\hline \multicolumn{7}{|l|}{ Animal and Plant Inspection Service } \\
\hline Intertribal Agricultural Council (IAC) Interagency Contract & 0 & 0 & 0 & 132 & 132 & 135 \\
\hline IAC Animal Health Training Contracts (2) & 0 & 0 & 0 & 314 & 315 & 321 \\
\hline IAC Outreach Initiative & 0 & 0 & 0 & 130 & 130 & 133 \\
\hline Montana/Wyoming Indian Stockgrowers Association & 0 & 0 & 0 & 36 & 36 & 36 \\
\hline $\begin{array}{l}\text { Native American Programs Coordinated by APHIS Native } \\
\text { American Working Group (ANAWG) }\end{array}$ & 0 & 0 & 0 & 300 & 300 & 300 \\
\hline $\begin{array}{l}\text { Nez Perce Tribe Training Agreement on Biological Control } \\
\text { of Weeds }\end{array}$ & 0 & 0 & 0 & 125 & 125 & 125 \\
\hline White Mountain Apache Agreement & 0 & 0 & 0 & 25 & 0 & 0 \\
\hline Homeland Security (HLS) Preparation Funds to Tribes & 0 & 0 & 0 & 0 & 0 & 1,050 \\
\hline $\begin{array}{l}\text { HLS Cooperative Agreement with Cherokee Nation for } \\
\text { Chronic Wasting Disease }\end{array}$ & 0 & 0 & 0 & 0 & 1,000 & 0 \\
\hline Total, APHIS & 0 & 0 & 0 & 1,062 & 2,038 & 2,099 \\
\hline \multicolumn{7}{|l|}{$\begin{array}{l}\text { Cooperative State Research, Education, and Extension } \\
\text { Service }\end{array}$} \\
\hline Native American Institutions Endowment Fund (NAIEF) & 4,600 & 4,600 & 7,100 & 7,100 & 7,100 & 9,000 \\
\hline Native American Institutions Endowment Fund Interest & 674 & 981 & 1,192 & 1,487 & 2,232 & 2,508 \\
\hline Tribal Colleges Education Equity Grants & 1,552 & 1,552 & 1,549 & 1,549 & 1,549 & 2,250 \\
\hline Extension Indian Reservations Program & 1,714 & 1,714 & 1,996 & 1,996 & 1,996 & 1,996 \\
\hline Extension Services at the 1994 Institutions & 2,060 & 3,060 & 3,273 & 3,273 & 3,273 & 3,273 \\
\hline Research Capacity BIdg. At 1994 Institutions & 0 & 500 & 998 & 998 & 998 & 998 \\
\hline $\begin{array}{l}\text { Alaska Native and Native Hawaiian-Serving Institutions } \\
\text { Education Grants }\end{array}$ & 0 & 0 & 2,993 & 2,997 & 2,997 & 2,997 \\
\hline Office of Outreach Section 2051-Outreach Grant Program & 0 & 945 & 945 & 945 & 945 & 945 \\
\hline Total, CSREES & 10,600 & 13,352 & 20,046 & 20,345 & 21,090 & 23,967 \\
\hline \multicolumn{7}{|l|}{ Economic Research Service } \\
\hline $\begin{array}{l}\text { R\&D Grants to Native American Institutions of Higher } \\
\text { Education for Economic Analysis and Research }\end{array}$ & 100 & 100 & 100 & 125 & 126 & 126 \\
\hline \multicolumn{7}{|l|}{ Farm Service Agency } \\
\hline Indian Land Acquisitions Loans & 0 & 673 & 2,002 & 74 & 2,000 & 2,000 \\
\hline $\begin{array}{l}\text { Outreach Activities Administered by USDA Office of } \\
\text { Outreach }\end{array}$ & 0 & 418 & & 993 & 0 & 0 \\
\hline IAC, Outreach Initiative & & & 125 & & & \\
\hline Total, FSA & 0 & 1,091 & 2,127 & 1,067 & 2,000 & 2,000 \\
\hline \multicolumn{7}{|l|}{ Commodity Credit Corporation } \\
\hline American Indian Livestock Feed Program & 3,896 & 6,874 & 13,704 & 2,186 & 5,502 & 0 \\
\hline \multicolumn{7}{|l|}{ Rural Development } \\
\hline Earmark for Rural Community Advancement Program & 0 & 12,000 & 20,169 & 19,948 & 15,896 & 13,000 \\
\hline $\begin{array}{l}\text { Earmark for Water \& Waste Disposal Systems for Rural \& } \\
\text { Native Villages in Alaska }\end{array}$ & 0 & 19,703 & 19,780 & 24,124 & 29,209 & 11,800 \\
\hline Earmark for Community Facility Loans \& Grants & 0 & 0 & 3,984 & 3,800 & 4,000 & 0 \\
\hline $\begin{array}{l}\text { Earmark for Rural Development Loan Fund Intermediary } \\
\text { Relending Program }\end{array}$ & 0 & 0 & 3,984 & 3,000 & 3,549 & 0 \\
\hline $\begin{array}{l}\text { Total, Earmark for Rural Development Native American } \\
\text { Programs }\end{array}$ & 0 & 31,703 & 47,917 & 50,872 & 52,654 & 24,800 \\
\hline \multicolumn{7}{|l|}{ Food and Nutrition Service } \\
\hline Food Distribution Program on Indian Reservations (FDPIR) & 75,000 & 75,000 & 76,500 & 70,787 & 79,165 & 82,237 \\
\hline Food Stamp Program-Bison purchase & 0 & 0 & 3,000 & 3,000 & 3,000 & \\
\hline Total, FNS & 75,000 & 75,000 & 79,500 & 73,787 & 82,165 & 82,237 \\
\hline
\end{tabular}


TABLE 7.1 (continued)

Foreign Agricultural Service Intertribal Ag. Council (IAC) Outreach Initiative IAC \& National Tribal Development Council Readiness Seminars Total, FAS

\begin{tabular}{|c|c|c|c|c|c|}
\hline 1999 & 2000 & 2001 & 2002 & 2003 & $2004^{*}$ \\
\hline 25 & 25 & 27 & 0 & 0 & 0 \\
\hline S & 0 & 0 & 0 & 0 & 0 \\
\hline 25 & 25 & 27 & 0 & 0 & 0 \\
\hline
\end{tabular}

National Agricultural Statistics Service Recruitment and Training of Native Americans

\begin{tabular}{rrrrrr}
36 & 0 & 0 & 0 & 0 & 0 \\
\hline 104 & 0 & 55 & 0 & 0 & 0 \\
\hline $\mathbf{8 9 , 7 6 1}$ & $\mathbf{1 2 8 , 1 4 5}$ & $\mathbf{1 6 3 , 4 7 6}$ & $\mathbf{1 4 9 , 4 4 4}$ & $\mathbf{1 6 5 , 5 7 5}$ & $\mathbf{1 3 5 , 2 2 9}$ \\
\hline
\end{tabular}

Total, Native American Specific Programs

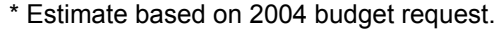

Source: U.S. Department of Agriculture, Office of Budget and Program Analysis, "United States Department of Agriculture, Programs for Native Americans and Native American Institutions, Program Level," submitted via e-mail, Feb. 14, 2003, updated July $15,2003$.

Between 1999 and 2003, USDA funding for Native American programs increased \$75.8 million or 84.4 percent after adjusting for inflation (see table 7.2). However, a large portion of the increase has been directed at only a few programs. For example, between 2000 and 2003, the Rural Development Native American set-aside increased \$21.0 million or 66.1 percent, and the Cooperative State Research, Education, and Extension Service set-aside increased \$7.7 million or 58.0 percent. In contrast, the Farm Service Agency's (FSA) Commodity Credit Corporation (aiding farmers through loans, purchases, payments, and other services) set-aside declined \$1.4 million or 20.0 percent, with no set-aside proposed for 2004. The Foreign Agricultural Service (which improves foreign market access for U.S. agricultural products) set-aside decreased by $\$ 25$ million or 100 percent (see table 7.1). ${ }^{6}$

\footnotetext{
${ }^{6}$ U.S. Department of Agriculture, Farm Service Agency, Farm Service Agency Online, "What Is the Farm Service Agency?" <http://www.fsa.usda.gov/pas/aboutus.htm>; U.S. Department of Agriculture, Farm Service Agency, Farm Service Agency Online, "Fact Sheet, Electronic Edition, Commodity Credit Corporation," November 1999, <http://www.fsa. usda.gov/pas/publications/facts.html/ccc99.htm>; U.S. Department of Agriculture, Foreign Agricultural Service, Foreign Agricultural Service Online, "Building Markets Overseas," Jan. 10, 2003, <http://www.fas.usda.gov/aboutfas.html>; USDA, "Guide to USDA Programs for American Indians and Alaska Natives."
} 
TABLE 7.2

Native American Program Funding Relative to Total USDA Budget, FY 1999-2004

(in millions of dollars)

\begin{tabular}{|c|c|c|c|c|c|c|}
\hline & 1999 & 2000 & 2001 & 2002 & 2003* & $2004^{\star *}$ \\
\hline USDA total & 92,010 & 105,399 & 103,107 & 101,475 & 106,694 & 105,730 \\
\hline & \multicolumn{2}{|c|}{$14.6 \%$} & \multicolumn{2}{|c|}{$(1.6 \%)$} & \multicolumn{2}{|c|}{$(0.9 \%)$} \\
\hline 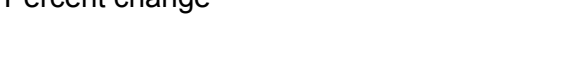 & \multicolumn{4}{|c|}{$(2.2 \%)$} & \multicolumn{2}{|c|}{$5.1 \%$} \\
\hline USDA total in constant 2003 dollars & 99,869 & 111,524 & 106,702 & 103,407 & 106,694 & 103,790 \\
\hline & & & & & & \\
\hline & & \multicolumn{2}{|c|}{$(4.3 \%)$} & \multicolumn{2}{|c|}{$3.2 \%$} & \\
\hline Average annual funding, 1999-2003 & \multicolumn{6}{|c|}{101,737} \\
\hline $\begin{array}{l}\text { Average annual funding in constant } 2003 \\
\text { dollars, 1999-2003 }\end{array}$ & \multicolumn{6}{|c|}{105,639} \\
\hline Change, 1999-2003 & \multicolumn{6}{|c|}{$\$ 14,684$ or $16.0 \%$} \\
\hline \multirow[t]{2}{*}{ Change in constant 2003 dollars, 1999-2003 } & \multicolumn{6}{|c|}{$\$ 6,825$ or $6.8 \%$} \\
\hline & 1999 & 2000 & 2001 & 2002 & 2003 & $2004^{* *}$ \\
\hline Native American programs & 89.8 & 128.1 & 163.5 & 149.4 & 165.6 & 135.2 \\
\hline & \multicolumn{2}{|c|}{$42.8 \%$} & \multicolumn{2}{|c|}{$(8.6 \%)$} & \multicolumn{2}{|c|}{$(18.4 \%)$} \\
\hline & & \multicolumn{2}{|c|}{$27.6 \%$} & \multicolumn{2}{|c|}{$10.8 \%$} & \\
\hline $\begin{array}{l}\text { Native American programs in constant } \\
2003 \text { dollars }\end{array}$ & 97.4 & 135.6 & 169.2 & 152.3 & 165.6 & 132.7 \\
\hline \multirow{2}{*}{ Percent change } & \multicolumn{2}{|c|}{$39.2 \%$} & \multicolumn{2}{|c|}{$(10.0 \%)$} & \multirow{2}{*}{\multicolumn{2}{|c|}{$(19.9 \%)$}} \\
\hline & \multicolumn{3}{|c|}{$24.8 \%$} & $8.7 \%$ & & \\
\hline Average annual funding, 1999-2003 & \multicolumn{6}{|c|}{139.3} \\
\hline $\begin{array}{l}\text { Average annual funding in constant } 2003 \\
\text { dollars, 1999-2003 }\end{array}$ & \multicolumn{6}{|c|}{144.0} \\
\hline Change, 1999-2003 & \multicolumn{6}{|c|}{$\$ 75.8$ or $84.4 \%$} \\
\hline Change in constant 2003 dollars, 1999-2003 & \multicolumn{6}{|c|}{$\$ 68.2$ or $70.0 \%$} \\
\hline \multicolumn{7}{|c|}{$\begin{array}{l}\text { "Estimated. } \\
\text { ** Estimate based on } 2004 \text { budget request. } \\
\text { Sources: U.S. Department of Agriculture, Office of Budget and Program Analysis, "FY } 2001 \text { Budget Summary," <http://www.usda.gov/ } \\
\text { agency/obpa/Budget-Summary/2001/text.htm>; U.S. Department of Agriculture, Office of Budget and Program Analysis, "FY } 2002 \text { Budget } \\
\text { Summary," <http://www.usda.gov/agency/obpa/Budget-Summary/2002/2002/budsum.htm>; U.S. Department of Agriculture, Office of Budget } \\
\text { and Program Analysis, "2003 Budget Summary," <http://www.usda.gov/agency/obpa/Home-Page/obpa.htm>; U.S. Department of Agricul- } \\
\text { ture, Office of Budget and Program Analysis, "2004 Budget Summary," <http://www.usda.gov/agency/obpa/Home-Page/obpa.htm>; U.S. } \\
\text { Department of Agriculture, Office of Budget and Program Analysis, "Programs for Native Americans and Native American Institutions, Pro- } \\
\text { gram Level," submitted via e-mail, Feb. 14, 2003, updated July 15, 2003. }\end{array}$} \\
\hline
\end{tabular}


Furthermore, although overall funding has increased, the percentage of USDA's total budget allocated to Native American programs remains miniscule. ${ }^{7}$ Table 7.3 shows that the percentage of USDA funding directly targeting Native Americans has continuously remained relatively small, despite the budget increases demonstrated above. In fact, these programs have constituted at most 0.0016 percent of USDA's budget between 1999 and 2003. At its lowest point, in 1999, Native American funding was just 0.001 percent of USDA's budget. The 2004 budget proposal reduces the portion targeted to Native Americans from the 2003 level to 0.0013 percent, roughly $\$ 28$ million less than 2001 and roughly $\$ 14.2$ million below 2002 (see table 7.3). ${ }^{8}$ A reduction of this size might appear small, but it is a significant amount for Native American communities lagging far behind the rest of the United States in the areas USDA's programs were designed to address. ${ }^{9}$

TABLE 7.3

Native American Program Funding as a Percentage of Total USDA Budget, FY 1999-2004 (in millions of dollars)

\begin{tabular}{lcccccc}
\hline & $\mathbf{1 9 9 9}$ & $\mathbf{2 0 0 0}$ & $\mathbf{2 0 0 1}$ & $\mathbf{2 0 0 2}$ & $\mathbf{2 0 0 3}$ & $\mathbf{2 0 0 4}$ \\
\cline { 2 - 6 } USDA total & 92,010 & 105,399 & 103,107 & 101,475 & $106,694^{*}$ & 105,730 \\
& 89.8 & 128.1 & 163.5 & 149.4 & 165.6 & 135.2 \\
Native American programs & or & or & or & or & or & $0.001 \% \%$ \\
& $0.001 \%$ & $0.0012 \%$ & $0.0016 \%$ & $0.0015 \%$ & $0.0016 \%$ & $0.0013 \%$ \\
\hline
\end{tabular}

Note: Numbers are rounded and percentages are approximate.

${ }^{*}$ Estimated.

** Estimate based on 2004 budget request.

Sources: U.S. Department of Agriculture, Office of Budget and Program Analysis, "FY 2001 Budget Summary," <http://www.usda.gov/ agency/obpa/Budget-Summary/2001/text.htm>; U.S. Department of Agriculture, Office of Budget and Program Analysis, "FY 2002 Budget Summary," <http://www.usda.gov/agency/obpa/Budget-Summary/2002/2002/budsum.htm>; U.S. Department of Agriculture, Office of Budget and Program Analysis, "2003 Budget Summary," <http://www.usda.gov/agency/obpa/Home-Page/obpa.htm>; U.S. Department of Agriculture, Office of Budget and Program Analysis, "2004 Budget Summary," <http://www.usda.gov/agency/obpa/Home-Page/obpa.htm>; U.S. Department of Agriculture, Office of Budget and Program Analysis, "Programs for Native Americans and Native American Institutions, Program Level," submitted via e-mail, Feb. 14, 2003, updated July 15, 2003.

\footnotetext{
${ }^{7}$ U.S. Census Bureau, “The American Indian and Alaska Native Population: 2000,” February 2002; U.S. Department of Health and Human Services, Indian Health Service, FY 2004 Budget Request, Justification of Estimates for Appropriations Committees, <http://www.ihs.gov/AdminMngrResources/Budget/FY_2004_Budget_Justification.asp>, p. 93; see Senator Ben Nighthorse Campbell, chair, and Senator Daniel K. Inouye, vice chair, Senate Committee on Indian Affairs, letter to the Senate Committee on the Budget, Mar. 1, 2002, as reported in Concurrent Resolution on the Budget, FY 2003, Report of the Committee on the Budget, United States Senate, Apr. 11, 2002, p. 120.

${ }^{8}$ USDA, "Programs for Native Americans"; U.S. Department of Agriculture, Office of Budget and Program Analysis, "FY 2001 Budget Summary," <http://www.usda.gov/agency/obpa/Budget-Summary/2001/text.htm> (hereafter cited as USDA, "FY 2001 Budget Summary"); U.S. Department of Agriculture, Office of Budget and Program Analysis, "FY 2002 Budget Summary," <http://www.usda.gov/agency/obpa/Budget-Summary/2002/2002/budsum.htm> (hereafter cited as USDA, "FY 2002 Budget Summary"); U.S. Department of Agriculture, Office of Budget and Program Analysis, "FY 2003 Budget Summary," < http://www.usda.gov/agency/obpa/Home-Page/obpa.htm> (hereafter cited as USDA, "FY 2003 Budget Summary"); U.S. Department of Agriculture, Office of Budget and Program Analysis, "FY 2004 Budget Summary," $<$ http://www.usda.gov/agency/obpa/Home-Page/obpa.htm> (hereafter cited as USDA, "FY 2004 Budget Summary").

${ }^{9}$ Senator Jeff Bingaman, "Bipartisan Group of Senators Joins Bingaman in Calling for Funds to Improve Infrastructure in Indian Country," News and Information, Apr. 9, 2003, <http://www.senate.gov/ bingaman/Press_Files/Press_Release/ press_release_1.html> (hereafter cited as Bingaman, "Indian Country").
} 


\section{Unmet Development and Nutritional Needs}

USDA programs help Native Americans end the cycle of unemployment and the accompanying poverty enveloping tribal communities. ${ }^{10}$ Through USDA's Rural Development Program tribal governments and Native American individuals and organizations receive funds to develop business enterprises within their own communities, thus providing jobs where none existed. The Food and Nutrition Service provides Native Americans with nutritious meals often, and for far too many, out of reach. In communities where hunger is common and food scarcity prevalent, USDA funds are frequently the difference between a next meal and no meal at all.

\section{Poverty and Unemployment}

Unemployment and poverty have continuously plagued the vast majority of Native American communities. On some reservations, unemployment levels have reached 85 percent. ${ }^{11}$ According to the 2000 census, average unemployment on reservations is 13.6 percent, more than twice the national rate. $^{12}$ Likewise, 31.2 percent of reservation inhabitants live in poverty, and the national poverty rate for Native Americans is 24.5 percent. ${ }^{13}$ By contrast, the national poverty rate in the United States between 1999 and 2001 was 11.6 percent. ${ }^{14}$ Having reached crisis proportions, disparities in impoverishment and unemployment offer further evidence of the federal government's failure to protect the rights of and promote equal opportunities for Native Americans.

Among the numerous tribes experiencing debilitating unemployment and poverty are the Navajo, Northern Arapaho, and Eastern Shoshone. ${ }^{15}$ Per capita income among the Navajo was \$5,599 in 1997, only 39 percent of the income for the general population a full seven years earlier (1990). In 2002, 56 percent of Navajos lived below the poverty level. ${ }^{16}$ The national poverty threshold for an individual under age 65 in 2002 was \$9,359 and \$8,628 for individuals aged 65 or older. ${ }^{17}$ The 2002 unemployment rate on the Navajo reservation was about 50 percent. ${ }^{18}$ Unemployment among the general population in 2002 was 5.8 percent. $^{19}$

\footnotetext{
${ }^{10}$ Other agencies, including the Department of Housing and Urban Development and the Department of Labor, have economic development and employment programs in place as well.

${ }^{11}$ Ardy Sixkiller Clarke, "Social and Emotional Distress Among American Indian and Alaska Native Students: Research Findings," Special Edition, ERIC Digest, January 2002, < http://www.indianeduresearch.net/edorc01-11.htm> (hereafter cited as Clarke, "American Indian and Alaska Native Students").

12 U.S. Census Bureau, "Employment Status and Commuting to Work: 2000," summary file, <http://www.factfinder. census.gov/servlet/GCTTable? ts $=75215796856>$.

${ }^{13}$ U.S. Census Bureau, "Poverty in the United States: 2001," Current Population Reports, September 2002, p. 7; U.S. Census Bureau, "Selected Social and Economic Characteristics for the 25 Largest American Indian Tribes," August 1995.

${ }^{14}$ U.S. Census Bureau, "Poverty in the United States: 2001," Current Population Reports, September 2002, p. 7.

${ }^{15}$ Navajo Nation, testimony before the Senate Committee on Environment and Public Works, Subcommittee on Transportation, Infrastructure, and Nuclear Safety, Washington, D.C., Aug. 8, 2002, <http://www.senate.gov/-epw/107th/Navaho 080802.htm $>$ (hereafter cited as Navajo testimony); Judith Antell et al., "Residential and Household Poverty of American Indians on the Wind River Indian Reservation" (University of Wyoming, Department of Sociology, 1999), pp. 7-12 (hereafter cited as Antell, "Residential and Household Poverty").

${ }^{16}$ Navajo testimony.

${ }^{17}$ U.S. Census Bureau, "Poverty 2002," Feb. 26, 2003, <http://www.census.gov/hhes/poverty/threshold/thresh02.html>.

${ }^{18}$ Navajo testimony.

${ }^{19}$ U.S. Department of Labor, Bureau of Labor Statistics, "Labor Force Statistics from the Current Population Survey," $<$ http://www.bls.gov/cps/home.htm> (hereafter cited as BLS, "Labor Force Statistics").
} 
These trends repeat themselves among the Northern Arapaho and Eastern Shoshone on the Wind River Reservation in Wyoming. In 1998, 62.4 percent of Northern Arapaho families lived below the poverty level. Fairing slightly better was the Eastern Shoshone, with 49.5 percent of its families below the poverty level in $1998 .^{20}$ The poverty threshold for a four-member family without children in 1998 was $\$ 16,813 .^{21}$ Wind River had a 38.1 percent unemployment rate in 1998 , compared with a national unemployment rate of 4.5 percent. $^{22}$

\section{Rural Development}

Persistent poverty and unemployment could largely be remedied by sustained rural development, a goal USDA has recognized since 1994 when it created the Rural Development Program. Within this program, one of the subprograms in which funds are set aside for Native Americans is the Rural Community Advancement Program, which promotes strategic development activities and collaborative efforts among federally recognized Indian tribes to maximize the effect of federal financial assistance. ${ }^{23}$

The yearly set-aside for Native Americans averaged \$17.0 million between 2000 and $2003 .{ }^{24}$ However, it fluctuated substantially during this period (see table 7.4$).{ }^{25}$ Fluctuating funding levels impede Native American groups from establishing solid economic bases in their communities. When funding is reduced, projects are left unfinished and do not fulfill their goals. Consequently, rural development fails to materialize and tribes are unable to sustain economic development. The Pueblo of Zuni in New Mexico, for example, states that stable funding is necessary to build an infrastructure, without which only limited economic development is feasible. ${ }^{26}$

TABLE 7.4

Native American Set-Aside for Rural Community Advancement Program, FY 1999-2004 (in thousands of dollars)

\begin{tabular}{lcccccc}
\hline & $\mathbf{1 9 9 9}$ & $\mathbf{2 0 0 0}$ & $\mathbf{2 0 0 1}$ & $\mathbf{2 0 0 2}$ & $\mathbf{2 0 0 3}$ & $\mathbf{2 0 0 4}$ \\
\cline { 2 - 6 } Native American set-aside & $0^{*}$ & 12,000 & 20,169 & 19,948 & 15,896 & 13,000 \\
& & & 8,169 & $(221)$ & $(4,052)$ & $(2,896)$ \\
or & or & or & or & $(1.1 \%)$ & $(20.3 \%)$ & $(18.2 \%)$ \\
\hline
\end{tabular}

* Data not available from USDA.

** Estimate based on 2004 budget request.

Source: U.S. Department of Agriculture, Office of Budget and Program Analysis, "Programs for Native Americans and Native American Institutions, Program Level," submitted via e-mail, Feb. 14, 2003, updated July 15, 2003.

\footnotetext{
${ }^{20}$ Antell, "Residential and Household Poverty," p. 9.

${ }^{21}$ U.S. Census Bureau, "Poverty 1998," Aug. 22, 2002, <http://www.census.gov/hhes/poverty/threshld/thresh98.html>.

${ }^{22}$ Antell, "Residential and Household Poverty," p. 7; BLS, "Labor Force Statistics."

${ }^{23}$ U.S. Department of Agriculture, letter to U.S. Commission on Civil Rights, Apr. 3, 2003, Responses to Interrogatory for Native American Project (hereafter cited as USDA, Responses to Interrogatory).

${ }^{24}$ USDA, "Programs for Native Americans."

${ }^{25}$ U.S. Department of Agriculture, Office of Budget and Program Analysis, "United States Department of Agriculture, New Budget (Obligational) Authority by Appropriation, Fiscal Years 1995 through 2002, and Estimates for 2003 and 2004," <http://www.usda.gov/agency/obpa/Home-Page/obpa.html> (hereafter cited as USDA, "New Budget Authority").

${ }^{26}$ Malcolm B. Bowekaty, governor, Pueblo of Zuni, testimony before the Senate Committee on Indian Affairs, Washington, D.C., June 14, 2000 (hereafter cited as Bowekaty testimony).
} 
Despite these problems, the proposed 2004 budget may decrease the set-aside by almost $\$ 7$ million or 34.8 percent from 2002 and 18.2 percent from 2003 (see table 7.4). ${ }^{27}$ The increase between 2000 and 2001 was not maintained in 2002 or 2003 and, if the 2004 budget request is approved, the setaside will have increased only $\$ 1$ million or 8.3 percent in four years (see table 7.5). The end result will be a reduction in what Native Americans are able to accomplish with the funds. ${ }^{28}$ Consequently, the National Congress of American Indians (NCAI) urges Congress to authorize 100 percent of Rural Development Program costs for the most economically disadvantaged tribes that otherwise would have no recourse. ${ }^{29}$

TABLE 7.5

Native American Set-Aside for Rural Community Advancement Program in Constant 2003 Dollars, FY 1999-2004 (in thousands of dollars)

\begin{tabular}{|c|c|c|c|c|c|c|}
\hline & 1999 & 2000 & 2001 & 2002 & 2003 & $2004^{*}$ \\
\hline $\begin{array}{l}\text { Rural Community Advancement Program } \\
\text { Native American set-aside }\end{array}$ & 0 & 12,000 & 20,169 & 19,948 & 15,896 & 13,000 \\
\hline Average annual funding, 2000-2003 & \multicolumn{6}{|c|}{17,003} \\
\hline Change, $2000-2003^{* *}$ & \multicolumn{6}{|c|}{$\$ 3,896$ or $32.5 \%$} \\
\hline In constant 2003 dollars & 0 & 12,697 & 20,872 & 20,328 & 15,896 & 12,761 \\
\hline Average annual funding, $2000-2003$ & \multicolumn{6}{|c|}{17,448} \\
\hline Change, 2000-2003 & \multicolumn{6}{|c|}{$\$ 3,199$ or $25.2 \%$} \\
\hline
\end{tabular}

* Estimate based on 2004 budget request.

** 2000-2003 is measured because no funding was set aside in FY 1999.

Source: U.S. Department of Agriculture, Office of Budget and Program Analysis, "Programs for Native Americans and Native American Institutions, Program Level," submitted via e-mail, Feb. 14, 2003, updated July 15, 2003.

Native Americans have previously seen federal program funding increase dramatically only to see it decline just as dramatically. For example, between 1979 and 1989 federal funding of Native American programs decreased 44 percent (from $\$ 4.45$ billion in 1979 to $\$ 2.5$ billion in 1989 ). ${ }^{30}$ Among the programs hit especially hard by decreased funding were those promoting economic development. ${ }^{31}$

In addition to reduced funding, Native Americans face disparate treatment when dealing with USDA. Many Native Americans state that program requirements deny them full and equitable access to USDA programs. ${ }^{32}$ The Gila River Indian Community in Arizona, for example, states that USDA regulations make reservation farmers the least likely of any group to receive USDA payments or loans. Moreover, Native American farmers must vie for USDA funds with non-indigenous farmers

\footnotetext{
${ }^{27}$ USDA, "Programs for Native Americans."

${ }^{28}$ National Congress of American Indians, "Testimony of the National Congress of American Indians on FY 2003 Department of Agriculture Appropriations," <http://www.ncai.org/main/pages/issues/other_issues/documents/Approps/AG03.pdf>.

${ }^{29}$ Ibid. See also National Congress of American Indians, "National Congress of American Indians, October 1999 Update on the FY 2000 Appropriations Process"; National Congress of American Indians, "Policy Statement of the National Congress of American Indians on Tribal Government Issues Included in the FY 2000 Appropriations Process,” Oct. 6, 1999 , p. 1.

${ }^{30}$ Nancy Cole, U.S. Department of Agriculture, Food and Nutrition Service, "The Characteristics of Native American WIC Participants, On and Off Reservations," May 2002, pp. 13-14 (hereafter cited as Cole, "WIC Participants"). Funding amounts are based on constant 1990 dollars.

${ }^{31}$ Cole, "WIC Participants," pp. 13-14.

${ }^{32}$ Senator Ben Nighthorse Campbell, chair, and Senator Daniel K. Inouye, vice chair, Senate Committee on Indian Affairs, letter to the Senate Committee on the Budget, Mar. 14, 2001, p. 10 (hereafter cited as Senators Campbell and Inouye, letter to the Senate Committee on the Budget, Mar. 14, 2001).
} 
who have an established relationship with the agency, making it even more difficult for Native American farmers to obtain funds. ${ }^{33}$

\section{Food Distribution Program on Indian Reservations}

Through the Food Distribution Program on Indian Reservations (FDPIR), FNS provides food to lowincome Native American households on and near reservations. Monthly food distributions are provided free to eligible households from what are typically warehouses located on reservations. ${ }^{34}$ Food is also dispersed by "tailgate distribution" from the rear of a truck. ${ }^{35}$ USDA provides program administration costs from a separate account, thus not affecting program funding. ${ }^{36}$

Native Americans suffer food insecurity and hunger at twice the rate of the general population. USDA found that from 1995 to 1997, 22.2 percent of Native American households were food insecure, meaning they did not have enough food to meet even their basic needs. In fact, the situation was so severe that USDA determined that from 1995 to 1997, one or more members of these households suffered from moderate to severe hunger, with 8.6 percent of households experiencing both food insecurity and hunger. ${ }^{37}$ Among the Zuni, for example, all 2,000 children living in Zuni Pueblo are eligible for free breakfasts and lunches, with two-thirds of the reservation's inhabitants enrolled in federal food programs. ${ }^{38}$

By contrast, between 8.8 and 10.5 percent of households in the general population suffered food insecurity between 1995 to $2001 .{ }^{39}$ Households in the general population suffering food insecurity with

\footnotetext{
${ }^{33}$ Ardell Ruiz, assistant community manager, Gila River Indian Community, testimony before the Senate Committee on Indian Affairs, Washington, D.C., June 14, 2000.

${ }^{34}$ U.S. Department of Agriculture, Office of Congressional and Intergovernmental Relations, "Guide to USDA Programs for American Indians and Alaska Natives, Food, Nutrition and Consumer Services," Jan. 30, 2001, submitted via e-mail, Feb. 14, 2003, <http://www.usda.gov/news/pubs/indians/open.htm>. FDPIR is authorized under Section 4(b) of the Food Stamp Act of 1977, Pub. L. No. 95-113, 91 Stat. 958 to 979 (codified as amended in scattered sections of 7 U.S.C.) and Section 4(a) of Agriculture and Consumer Protection Act of 1973, Pub. L. No. 93-87 Stat. 221 (codified as amended in scattered sections of 7 U.S.C.). The federal regulations governing the program are found at 7 C.F.R. $\S \S 250,253$, and 254 (2003). FDPIR is an alternative to the Food Stamp Program available to Indian tribal organizations.

${ }^{35}$ U.S. Department of Agriculture, "The National Nutrition Safety Net, Food Distribution on Indian Reservations," Apr. 3, 2003, <http://www.fns.usda.gov/fsec/toolkit/fdpir.html>.

${ }^{36}$ USDA, Responses to Interrogatory; U.S. Department of Agriculture, Food and Nutrition Service, "Frequently Asked Questions, Food Distribution Program on Indian Reservations," July 31, 2002, <http://www.fns.usda.gov/fdd/programs/ fdpir/fdpirfaq.htm>.

${ }^{37}$ Food Research and Action Center, "WIC in Native American Communities: Building a Healthier America," 2000 , pp. 7-8 (hereafter cited as Food Research and Action Center, "WIC in Native American Communities").

38 Ron Franscell, “Indians' Aim: Better Diet," DenverPost.com, Nov. 8, 2002, <http://www.geocities.com/aaninin/ denverpost.html>.

${ }^{39}$ U.S. Department of Agriculture, Food and Nutrition Service, Office of Analysis, Nutrition, and Evaluation, "Measuring Food Security in the United States, Household Food Security in the United States, 1995-1998 (Advance Report)," Mar. 7, 2002, <http://www.fns.usda.gov/oane/MENU/Published/FoodSecurity/fsecsum.htm> (hereafter cited as USDA, "Measuring Food Security, 1995-1998”); U.S. Department of Agriculture, Food and Nutrition Service, Office of Analysis, Nutrition, and Evaluation, "Measuring Food Security in the United States, Household Food Security in the United States, 19951997, Technical Issues and Statistical Report," December 2001, pp. 133-36 (hereafter cited as USDA, "Measuring Food Security, 1995-1997"); Barbara Cohen, James Parry, and Kenneth Yang, IQ Solutions, "Household Food Security in the United States, 1998 and 1999," June 2002, p. 38 (hereafter cited as Cohen et al., "Household Food Security"); U.S. Department of Agriculture, Economic Research Service, "Household Food Security in the United States, 2001 ," p. 47 (hereafter cited as USDA/ERS, "Household Food Security").
} 
hunger during this same period varied between 3.1 and 3.9 percent. ${ }^{40}$ Despite the arguably large percentage of households in the general population experiencing food insecurity and hunger in any one of these years, the percentages are less than half of those for Native Americans. ${ }^{41}$

As seen in table 7.6, funding of FDPIR has fluctuated between 1999 and $2003 .{ }^{42}$ Funding for FDPIR averaged \$75.3 million and 0.0024 percent of FNS' total budget between 1999 and 2003. As a percentage of FNS total funding, it was at its lowest level in $2002,0.0022$ percent (see table 7.6). ${ }^{43}$ When adjusting FDPIR funding for inflation, what appears to be a $\$ 4.2$ million or 5.6 percent increase between 1999 and 2003 is actually a decrease of $\$ 2.2$ million or 2.8 percent (see table 7.7). ${ }^{44}$ That is, over the years FDPIR has lost real spending power. Had the percentage of FNS budget to FDPIR remained at the 2001 level (0.0026 percent), FDPIR would be funded at $\$ 103.1$ million in 2004. In other words, it would receive \$21 million or 25.3 percent more funding in 2004 than the proposed level (see tables 7.6 and 7.7). ${ }^{45}$ Overall, FDPIR is a very small proportion of FNS' budget despite the documented nutrition needs among Native Americans.

TABLE 7.6

Food Distribution Program on Indian Reservations Funding Relative to Total Program Funding, FY 1999-2004 (in millions of dollars)

\begin{tabular}{|c|c|c|c|c|c|c|}
\hline & 1999 & 2000 & 2001 & 2002 & 2003 & $2004^{* *}$ \\
\hline Food and Nutrition Service ${ }^{\wedge}$ & 29,672 & 30,111 & 28,950 & 32,656 & $37,089^{*}$ & 39,645 \\
\hline Percent change & \multicolumn{4}{|c|}{$(3.9 \%)$} & \multicolumn{2}{|c|}{$6.9 \%$} \\
\hline $\begin{array}{l}\text { Food Distribution Program on } \\
\text { Indian Reservations }{ }^{\wedge}\end{array}$ & 75.0 & 75.0 & 76.5 & 70.8 & 79.2 & 82.2 \\
\hline Change from previous year & $\mathrm{N} / \mathrm{A}$ & 0 & $\begin{array}{c}1.5 \\
\text { or } \\
2.0 \%\end{array}$ & $\begin{array}{c}(5.7) \\
\text { or } \\
(7.5 \%)\end{array}$ & $\begin{array}{c}8.4 \\
\text { or } \\
11.9 \%\end{array}$ & $\begin{array}{c}3.1 \\
\text { or } \\
3.9 \%\end{array}$ \\
\hline Percent of FNS total & $0.0025 \%$ & $0.0025 \%$ & $0.0026 \%$ & $0.0022 \%$ & $0.0021 \%$ & $0.0021 \%$ \\
\hline $\begin{array}{l}\text { Note: Numbers are rounded. } \\
\text { * Estimated. } \\
\text { ** Estimate based on } 2004 \text { budget } \\
\wedge \text { Based on USDA mandatory/direc } \\
\wedge \wedge \text { Percentages are approximate. } \\
\text { Sources: U.S. Department of Agric } \\
\text { Department of Agriculture, New Bu } \\
\text { and } 2004, "<\text { http://www.usda.gov/ } \\
\text { Analysis, "United States Departme } \\
\text { mitted via e-mail, Feb. 14, 2003, up }\end{array}$ & $\begin{array}{l}\text { est. } \\
\text { propriations. } \\
\text { re, Office of } \mathrm{E} \\
\text { t (Obligation } \\
\text { ncy/obpa/Ho } \\
\text { f Agriculture, } \\
\text { ed July } 15,2\end{array}$ & $\begin{array}{l}\text { and Progr } \\
\text { hority by } \\
\text { ge/obpa.ht } \\
\text { ams for } N\end{array}$ & $\begin{array}{l}\text { alysis, } 200 \\
\text { riation, Fis } \\
\text { S. Depa } \\
\text { mericans }\end{array}$ & $\begin{array}{l}\text { get Tables, } \\
\text { ars } 1995 \text { t } \\
\text { of Agricul } \\
\text { ative Ameri }\end{array}$ & $\begin{array}{l}\text { udget Auth } \\
2002 \text {, and } \\
\text { ffice of } \mathrm{Bu} \\
\text { titutions, } \mathrm{Pr}\end{array}$ & $\begin{array}{l}\text { United States } \\
\text { ates for } 2003 \\
\text { and Program } \\
\text { n Level," sub- }\end{array}$ \\
\hline
\end{tabular}

\footnotetext{
${ }^{40}$ USDA/ERS, "Household Food Security," p. 47; USDA, "Measuring Food Security, 1995-1998”; USDA, "Measuring Food Security, 1995-1997," pp. 133-36; Cohen, "Household Food Security,” p. 38.

${ }^{41}$ Food Research and Action Center, "WIC in Native American Communities," pp. 7-8.

${ }^{42}$ USDA, "Programs for Native Americans."

${ }^{43}$ Ibid. USDA, "New Budget Authority."

${ }^{44}$ USDA, "Programs for Native Americans."

${ }^{45}$ Ibid. USDA, "New Budget Authority."
} 
According to USDA, overall participation in the program declined between 1998 and 2002 although participation increased between 1998 and 1999. ${ }^{46}$ On the Northern Cheyenne Indian reservation in Montana, for example, participation in FDPIR increased 15 percent between July 1998 and June 1999. ${ }^{47}$ Data for 2002 are preliminary and data for all years are subject to revision, however, implying that it is difficult for USDA to know exactly how many Native Americans participate each year (see figure 7.1). ${ }^{48}$

TABLE 7.7

Food Distribution Program on Indian Reservations in Constant 2003 Dollars, FY 1999-2004 (in thousands of dollars)

\begin{tabular}{|c|c|c|c|c|c|c|}
\hline & 1999 & 2000 & 2001 & 2002 & 2003 & $2004^{*}$ \\
\hline Food Distribution Program on Indian Reservations & 75,000 & 75,000 & 76,500 & 70,787 & 79,165 & 82,237 \\
\hline Average annual funding, 1999-2003 & \multicolumn{6}{|c|}{75,290} \\
\hline Change, 1999-2003 & \multicolumn{6}{|c|}{$\$ 4,165$ or $5.6 \%$} \\
\hline In constant 2003 dollars & 81,407 & 79,359 & 79,167 & 72,135 & 79,165 & 80,728 \\
\hline Average annual funding, 1999-2003 & \multicolumn{6}{|c|}{78,247} \\
\hline Change, 1999-2003 & \multicolumn{6}{|c|}{$(\$ 2,242)$ or $(2.8 \%)$} \\
\hline
\end{tabular}

*Estimate based on 2004 budget request.

Source: U.S. Department of Agriculture, Office of Budget and Program Analysis, "Programs for Native Americans and Native American Institutions, Program Level," submitted via e-mail, Feb. 14, 2003, updated July 15, 2003.

Decreasing participant rates do not necessarily mean there are fewer reservation inhabitants in need of food assistance programs. Native Americans on a Montana reservation, for example, cite the lack of transportation or gas money to pay others for transportation as obstacles to making and keeping appointments with program personnel. Lack of telephones is also a primary reason why Native Americans needing food assistance on this reservation do not participate in such programs. Individuals without telephones have limited contact with program personnel, initially or otherwise, to make or revise appointments. This point is critical because currently several visits are required to apply for benefits, and appointments are often missed because of transportation problems. Previously, program participants did not have to meet with program personnel as often and missed appointments were not automatically construed as lack of actual need or interest. However, even after successfully navigating these hurdles, many Native Americans residing on this reservation state that the massive paperwork required of program applicants and the complexity of the system prevent individuals from establishing or maintaining eligibility despite needing and falling within the established criteria for food assistance. ${ }^{49}$

Although the argument can be made that funding is adequate because participation in FDPIR has decreased since 1999, that claim would ignore several key issues. First, as discussed above, Native Americans in need of food assistance may not participate in such programs for various reasons, including lack of access to program personnel and complex enrollment procedures. ${ }^{50}$ Second, FDPIR

\footnotetext{
${ }^{46}$ U.S. Department of Agriculture, Food and Nutrition Service, "Food Distribution Program on Indian Reservations: Persons Participating," Mar. 31, 2003, <http://www.fns.usda.gov/pd/fd\$sum.htm> (hereafter cited as USDA, “FDPIR").

${ }^{47}$ Judith Davis, Rita Hiwalker, and Carol Ward, "Food Assistance Programs on a Montana Indian Reservation," Poverty Research News, vol. 5, no. 2 (March/April 2001), p. 10 (hereafter cited as Davis, "Food Assistance Programs”).

${ }^{48}$ USDA, "FDPIR."

${ }^{49}$ Davis, "Food Assistance Programs," pp. 10-11.

${ }^{50}$ Ibid. Eddie F. Brown et al., "Welfare, Work, and American Indians: The Impact of Welfare Reform," A Report to the National Congress of American Indians, Nov. 27, 2001, p. iv (hereafter cited as Brown, "Welfare, Work, and American Indians").
} 
participants also participate in other food assistance programs, implying that FDPIR alone is not adequately meeting the food needs of Native Americans. For example, 41.6 percent of Native Americans enrolled in the Special Supplemental Nutrition Program for Women, Infants, and Children (WIC) also participate in FDPIR and the Food Stamp Program. ${ }^{51}$ Third, other federal assistance programs (although not specifically food assistance but critical in ensuring Native Americans have enough to eat) do not provide Native Americans with enough monetary resources to purchase food. For example, federal Temporary Assistance for Needy Families (TANF) tribal-specific funding is not adjusted for inflation, resulting in a loss of purchasing power among enrolled Native Americans. A bad situation is made worse for some tribes since not all states match federal TANF dollars, further reducing the resources available to these tribes. ${ }^{52}$

Furthermore, some tribes have to subsidize administrative costs and food warehousing and storage facilities for FDPIR and other food assistance programs because funding has been insufficient to cover these costs. Consequently, resources that would have been used to purchase food have been redirected to cover the costs of storing food obtained through FDPIR ${ }^{53}$ Federal nutrition programs, in general, have been affected by reduced funding for their management. That is, the funds to oversee and make improvements to programs have declined as government resources directed toward this end have been limited for a number of years. ${ }^{54}$

FIGURE 7.1

Food Distribution Program on Indian Reservations Participation, FY 1998-2002

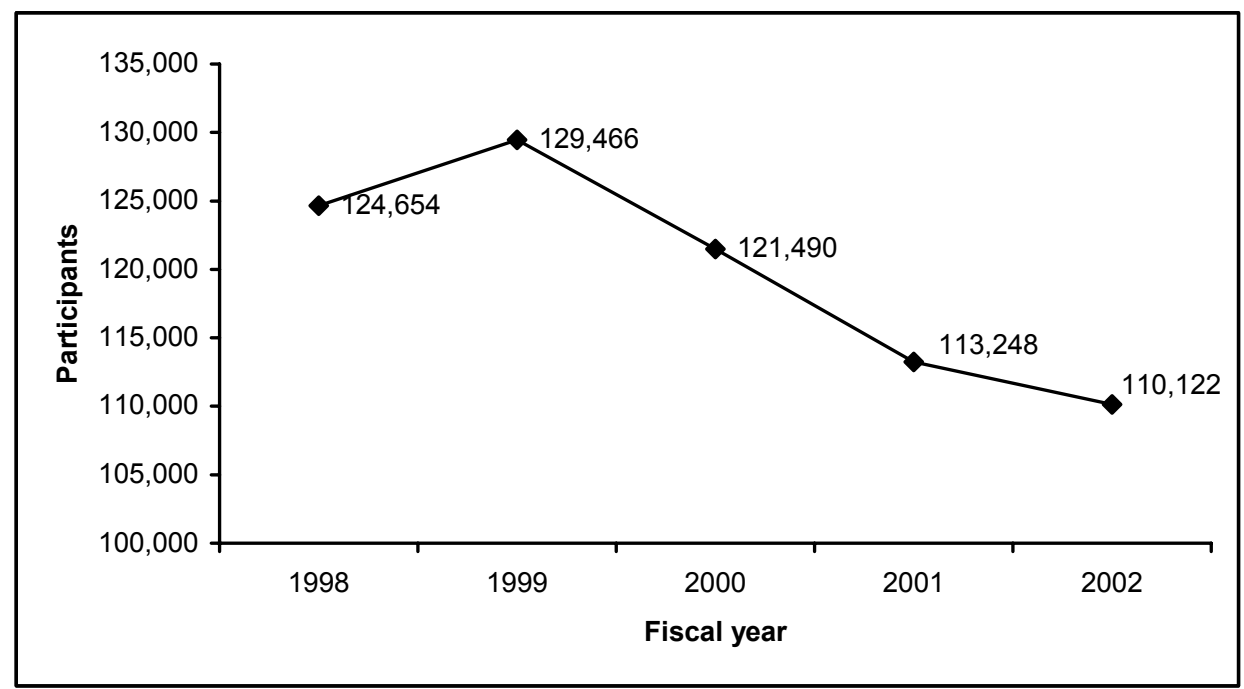

Source: U.S. Department of Agriculture, Food and Nutrition Service, "Food Distribution Program on Indian Reservations: Persons Participating," Mar. 31, 2003, <http://www.fns.usda.gov/pd/fd\$sum.htm>.

Less oversight of nutrition programs has forced Native Americans to deal with increasing bureaucracy at the same time that services have been reduced, a situation leading to less food reaching hun-

${ }^{51}$ Cole, "WIC Participants," pp. iv, 22.

${ }^{52}$ Henry J. Kaiser Family Foundation, American Indian Families and Tribes: Key Issues in Welfare Reform Authorization, April 2002, p. 3. As of April 2002, overall TANF funding was not adjusted for inflation. See ibid., p. 2.

${ }^{53}$ Bowekaty testimony.

${ }^{54}$ Dan Glickman, Secretary of Agriculture, testimony before the Senate Subcommittee on Agriculture, Rural Development, and Related Agencies, Washington, D.C., Feb. 10, 2000, <http://www.usda.gov/news/special/ctc13.htm>. 
gry families. ${ }^{55}$ The need to increase food assistance programs on reservations is clearly evident as detailed above. According to a study of federal assistance programs for Native Americans, 45 percent of residents on three Arizona reservations in 2000-2001 indicated that they sometimes could not afford to buy food. Twenty-five percent said their children went to bed or school hungry. Seventeen percent said that in the three months prior to being interviewed there was not enough food to eat, with 3 percent saying that in those three months there was often not enough food. ${ }^{56}$ The stories of these Native American families and others clearly show the need for adequate FDPIR funding to provide Native Americans with enough food to meet their needs and a healthy diet available to the general population.

\section{Conclusion}

Despite an overall increase in USDA's funding of Native American programs, the percentage of USDA funds directed at Native Americans remains miniscule. Between 1999 and 2003, Native Americans were directly targeted for 0.0016 percent of USDA's budget at most. In 1999, Native American programs received only 0.001 percent of USDA funds. ${ }^{57}$

Rural development is desperately needed in Indian Country because on some reservations unemployment is more than 70 percent, and is typically twice the national rate of unemployment for the general population. Moreover, poverty among reservation inhabitants is 31.2 percent, with the national poverty level for Native Americans reaching 24.5 percent. Poverty among the general population from 1999 to 2001 was 11.6 percent, less than half the annual rate among Native Americans. ${ }^{58}$ Fluctuating funding has hindered efforts to address these problems because projects undertaken have been subsequently discontinued for lack of funds. ${ }^{59}$ Whatever modest progress has been made as a result of the 2001 funding increase will be eroded if the 2004 budget request is approved, as it would reduce funding by nearly 35.5 percent from $2001 .^{60}$

Periods of increased funding, followed by a reduction in funding, have also hindered FDPIR ${ }^{61}$ This lack of fiscal stability compromises program effectiveness and compounds the problem of inadequate supplies of healthy food for Native Americans. This is critical because food insecurity and hunger are prevalent among Native Americans. Between 1995 and 1997, food insecurity among Native Americans was twice the national average. ${ }^{62}$

The above problems are compounded by the government's failure to ensure full and equitable access to USDA programs for Native Americans. USDA also has not provided adequate outreach to Native

\footnotetext{
55 Ibid.

${ }^{56}$ Brown, "Welfare, Work, and American Indians," p. 27.

${ }^{57}$ USDA, "Programs for Native Americans"; USDA, "FY 2001 Budget Summary"; USDA, "FY 2002 Budget Summary"; USDA, "FY 2003 Budget Summary"; USDA, "FY 2004 Budget Summary."

${ }^{57}$ Bingaman, "Indian Country."

${ }^{58}$ U.S. Census Bureau, "Poverty in the United States: 2001," Current Population Reports, September 2002, p. 7.

${ }^{59}$ Bowekaty testimony.

${ }^{60}$ USDA, "New Budget Authority."

${ }^{61}$ USDA, "Programs for Native Americans."

${ }^{62}$ Food Research and Action Center, "WIC in Native American Communities," pp. 7-8; USDA, "Measuring Food Security, 1995-1998"; USDA, "Measuring Food Security, 1995-1997,” pp. 133-36.
} 
Americans, and the performance of tribal-specific programs has not provided optimum service to Native Americans. ${ }^{63}$

The challenging conditions under which far too many Native Americans residing on reservations live demand that USDA programs geared toward providing these communities with an avenue to improve their economic conditions be fully funded. Funding, however, has generally not been sufficient for the numerous tasks facing Native American communities. These funding shortfalls can be summarized as follows:

- Although funding for USDA's Native American programs has increased during the period examined here, in 2004 funding may be \$30.3 million below 2003, \$14.2 million below 2002 , and $\$ 28.2$ million less than in 2001. Reductions of this size would have a severe impact on any group, but they are devastating for communities lagging far behind the rest of the United States in economic development and nutrition. Consequently, Native American communities may have to go without the development of tribal business ventures and adequate food supplies.

- When funding for FDPIR between 1999 and 2003 is adjusted for inflation, the program has lost $\$ 2.2$ million or 2.8 percent. The proposed 2004 budget provides $\$ 82.2$ million for this program, an increase of 3.9 percent over 2003. If funding were provided at the 2001 level, this program would receive $\$ 21$ million or 25.3 percent more funding in 2004. However, even if funding were provided at the 2001 level, it would not make up for the funding shortfalls experienced since 1999.

${ }^{63}$ Senators Campbell and Inouye, letter to the Senate Committee on the Budget, Mar. 14, 2001, p. 10. 


\section{Chapter 8: Closing the Gap-Addressing Unmet Needs Through Funding}

The magnitude of need for services in Indian Country clearly indicates that the federal government has largely failed [its] responsibility. Tribes fulfilled their promises when they ceded their lands, but the federal government has yet to fulfill its promises. ${ }^{1}$

A quiet crisis is occurring in Indian Country. Whether intentional or not, the government is failing to live up to its trust responsibility to Native peoples. The federal government undertook a legal and moral obligation to make up for what had been taken from Native Americans and to ensure their well-being. This obligation is rooted in the history of displacement of entire tribes and the confiscation of natural resources that they depended upon for their livelihood. Perennial government failure to compensate Native Americans and the residual effects of the nation's long history of mistreatment of Native peoples have increased the need for federal assistance even further. Efforts to bring Native Americans up to the standards of other Americans have failed in part because of a lack of sustained funding. The failure manifests itself in massive and escalating unmet needs in areas documented in this report and numerous others. The disparities in services show evidence of discrimination and denial of equal protection of the laws.

\section{The Growing Crisis: An Expression of Unmet Needs}

\section{Health Care}

Native Americans have lower life expectancy (nearly six years less) than any other group and higher rates of many diseases, including diabetes, tuberculosis, and alcoholism. Native Americans are also much more likely to suffer accidental death or commit suicide. Yet, health facilities are frequently inaccessible and medically obsolete; preventive care and specialty services are too few; and adequate sanitation facilities are not yet available to everyone. Most Native Americans do not have private health insurance and thus rely exclusively on the Indian Health Service for health care.

Despite widely documented health disparities, the federal government spends less per capita on Native American health care than on any other group for which it has this responsibility, including Medicaid recipients, prisoners, veterans, and military personnel. Annually, IHS spends 60 percent less on its beneficiaries than is spent on the average American for health care. Moreover, while other public health programs such as Medicare and Medicaid accrue annual interest to keep pace with inflation, IHS funds do not. The disparity in funding is amplified by the poorer health conditions of Native Americans. By most accounts, IHS has done well to work within its resource limitations and is regarded as an agency focused on the needs of Native Americans. If funded sufficiently, however, it could do more to stem the crisis.

\footnotetext{
1 Friends Committee on National Legislation, "Federal Spending and the Trust Responsibility," Feb. 28, 2001, $<$ http://www.fcnl.org/issues/nat/sup/indians_federalspending.htm>.
} 


\section{Housing}

The availability of safe, sanitary housing in Indian Country is significantly less than the need. Overcrowding and its effects are a persistent problem. It is not uncommon for large extended families to share small one-bedroom houses. In fact, a third of Native homes are overcrowded. The effects of overcrowding on children and adults alike are evident: poor performance in school; increased stress, which heightens the risk for alcoholism and abuse; unsanitary conditions; and higher rates of infectious disease.

Existing housing structures are substandard: approximately 40 percent of on-reservation housing is considered inadequate, compared with 6 percent nationwide. One in five reservation homes lacks complete plumbing, and 16 percent lack telephone service. Native American families wait twice as long as other American families for subsidized housing. They also have less access to homeownership resources, due to limited access to credit, land ownership restrictions, geographic isolation, and harsh environmental conditions that make construction difficult and expensive.

Unequal housing opportunities and standards lower than those available to other low-income individuals constitute a violation of Native Americans' civil rights. While HUD has made efforts to improve housing, lack of funding has hindered progress.

\section{Law Enforcement}

All three components of law enforcement-policing, justice, and corrections - are substandard in Indian Country compared with the rest of the nation. Native Americans are twice as likely as any other racial/ethnic group to be the victims of crime. Crimes on reservations are more likely to be violent in nature and racially incongruent (i.e., committed by non-Natives). Yet, per capita spending on law enforcement in Native American communities is roughly 60 percent of the national average, and significantly fewer police officers serve Indian Country than other rural areas. These factors, in addition to the disproportionately higher incarceration rates of Native Americans and unfair police practices, have perpetuated a profound mistrust of the criminal justice system. There is a strong perception of a dual system of justice and a correlation between race and law enforcement outcomes.

The U.S. criminal justice system often conflicts with traditional Native American culture. The divide between "mainstream" and Native justice furthers the mistrust, but efforts to develop and maintain tribal courts have been unsuccessful. Native Americans have long argued that tribal court systems do not have means to operate equal to other court systems, nor have they historically been funded sufficiently or consistently. Likewise, funding for juvenile justice programs and correctional facilities has not met the growing needs of Native communities.

There is consensus among law enforcement professionals that the dire situation in Indian Country is understated. While DOJ should be commended for its stated intention to meet its obligations to Native Americans, particularly in the late 1990s, promising projects have suffered from inconsistent or discontinued funding. Lack of adequate law enforcement has created unsafe communities that do not have fair and relevant justice systems.

\section{Education}

As a group, Native American students are not afforded educational opportunities equal to other American students. They routinely face deteriorating school facilities, underpaid teachers, weak cur- 
ricula, discriminatory treatment, and outdated learning tools. In addition, the cultural histories and practices of Native students are rarely incorporated in the learning environment. As a result, achievement gaps persist with Native American students scoring lower than any other racial/ethnic group in basic levels of reading, math, and history. Native American students are also less likely to graduate from high school and more likely to drop out in earlier grades.

The lack of educational opportunities in Native communities also extends to postsecondary and vocational programs, a problem that continues to erode and retard individual economic advancement. Special education programs for Indian adults have not been funded at all for years, and vocational rehabilitation programs that assist individuals with physical and mental challenges are too underfunded to meet the abundant need. Tribal colleges and universities receive 60 percent less federal funding per student than other public community colleges, resulting in increased financial burden for students who are already the most economically disadvantaged.

The substandard schools in Indian Country are products of debilitating poverty and lack of adequate federal funding. Because many states do not provide assistance to Native schools and because there is no local tax base to support education in Indian Country, the federal government has sole responsibility for providing education to these students - an obligation it has failed to meet.

\section{Rural Development and Food Distribution}

The USDA is largely responsible for rural development and farm and business supplements in rural communities. Native Americans rely on such programs to foster conditions that encourage and sustain economic investments by external sources. However, insufficient funding has limited the success of development programs and perpetuated unstable economies. Moreover, fluctuations in funding have impeded efforts to establish solid markets in Native communities.

Poor economic conditions have resulted in another crisis: food shortages and hunger. For all the prosperity of the United States, there remain communities that resemble developing nations with their prevalence of hunger and food insecurity. Many Native communities fall within this unacceptable category, as Native Americans are more than twice as likely as the general population to face hunger and food insecurity at any given time. High rates of unemployment and poverty render it difficult for many Native families to have regular meals, necessitating reliance on federal food distribution programs.

The inaccessibility of food and economic development programs compromises their usefulness. The isolated and rural situation of Native Americans often makes it difficult for them to meet with program administrators or to access food sources. Transportation and basic communication tools, such as telephones, are not available to Native Americans to the extent they are to other groups. Moreover, programs are less accessible to the Native American population because tribes often do not have the requisite equipment, expertise, or orientation to navigate the complex processes. By its failure to make programs to both tribes and individuals accessible, the federal government has denied Native Americans the opportunity to receive benefits routinely available to other citizens.

In sum, the Commission finds evidence of a crisis in the persistence and growth of unmet needs in the areas reviewed. A cross-cutting and universal problem is the absence of basic infrastructure in Native communities. In fact, much of the unmet need could be fulfilled with adequate funding for infrastructure that supports services, programs, and product delivery. Policymakers appear not to consider this, or the higher costs associated with providing services to geographically isolated Native 
communities. Following is a list of specific programs that, based on the Commission's analysis, are not funded in accordance with the true costs of delivery or the needs of the people they serve.

TABLE 8.1

Unmet Needs in Indian Country, by Agency

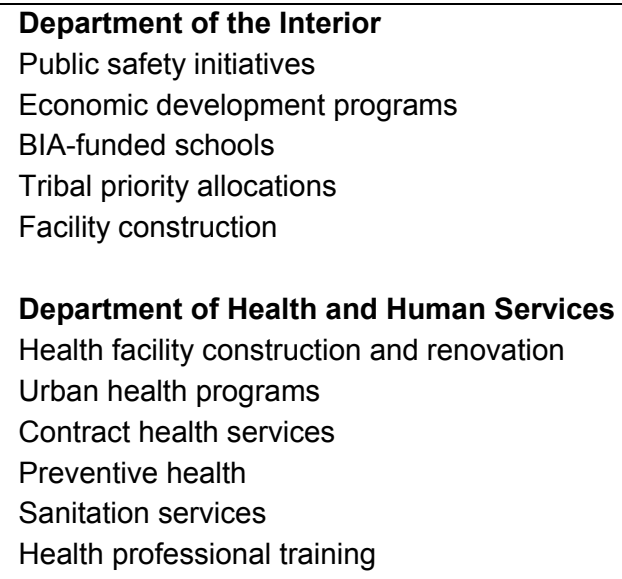

The agencies reviewed are responsible for addressing these needs; however, inadequate funding, overall and within specific program areas, has rendered doing so impossible. What is perhaps most revealing is that the conditions in Indian Country could be greatly relieved or remedied if the federal government honored its commitment to funding. Unfortunately, Native Americans living on tribal lands do not have access to the same services and programs available to other Americans, even though the government has a binding trust obligation to provide them. The trust responsibility makes the provision of services to Native Americans a legal entitlement, not just a moral, social, or economic one.

Not all federal agencies make efforts to assess actual needs, much less remedy them. Assessing the actual disparity in spending between Native Americans and other groups is difficult because rela- 
tively little comparative data are collected. For example, neither HUD nor any housing organizations collect information on expenditures for Native housing versus public subsidized housing. Analyses must be conducted of construction costs in rural Native areas versus urban centers, expenditures per housing unit and per resident, and remaining unmet needs (waiting lists, length of waiting time, etc.). Similarly, the Department of Education does not collect definitive data that would monitor per student spending in Indian Country compared with spending nationwide.

In reviewing the six agencies that control the largest share of Native American funding, the Commission has given context to the unmet obligations of the federal government. The findings that follow reveal both substantive and administrative problems. Substantively, deficiencies in funding levels have resulted in perpetuation of poor living conditions in Native communities. Administratively, the federal government fails to keep accurate and comprehensive records of its expenditures on Native American programs. Reporting is so fragmented that it renders global analysis of spending nearly impossible. Solutions to these problems are urgent and overdue.

\section{Funding Shortfalls}

Over the last 10 years, federal funding for Native American programs has increased significantly, but not to the level needed to eliminate the backlog of unmet needs or to raise the standard of living to that of other Americans. As noted above, the living conditions in Native communities remain unmatched by any other group in the United States, characterized by persistent poverty, poor health, and substandard housing and education. The severity of the situation constitutes a flagrant civil rights violation, as Native Americans are in essence denied equal opportunity by the federal government's failure to live up to its promises.

Federal spending on Native programs is relatively small in comparison to that for other populations. What might be perceived as a minor sum in other areas of federal spending is significant with respect to Indian funding. A million dollars is a large amount for the Indian Health Service, for example, when one considers the many badly needed services it could fund. Moreover, because so many tribes and communities are forced to compete for a share, decreases in Native American program funding, even when small, resonate throughout the population.

In examining the federal government's funding record over the last six years, the Commission accounted for inflation and found that many individual programs have lost spending power. In instances where funding for Native American programs has increased, those increases have been insufficient, and the budgets remain minute proportions of the overall budget authorities of the parent agencies. For examples:

- The Indian Health Service, although the largest source of federal spending on Native Americans, constitutes only 0.5 percent of the entire Department of Health and Human Services budget. Moreover, it makes up a smaller proportion of HHS' discretionary budget today than it did five years ago.

- Native American law enforcement funding increased almost 85 percent between 1998 and 2003, but the amount allocated was so small to begin with that its proportion to the Department of Justice's total budget hardly changed.

- Funding for Native American programs in the Department of Housing and Urban Development increased only slightly over the years, significantly less than the agency as a whole, and when deflated, amounted to a loss of spending power. 
- Likewise, funding for the Department of Education's Indian Education Program has decreased as a proportion of the department's total discretionary budget for the last two years.

- The Bureau of Indian Affairs receives a significant proportion of the Department of the Interior's overall appropriation each year; however, after adjusting for inflation, BIA's budget authority actually grew at a much slower rate than the department's total budget.

- The Food Distribution Program on Indian Reservations within the Department of Agriculture has also lost funding when accounting for inflation, negatively affecting available food resources and number of recipients.

These findings illustrate the federal government's withdrawal from its previous commitments and further demonstrate that Native American programs, as evidenced by their disproportionately small share of agency budgets, are not a high priority. Civil rights concerns are manifest in the fact that Native Americans often receive fewer services and less funding than other populations. Finally, this analysis proves the inversely proportional relationship between federal funding and unmet needs; as funding decreases, unmet needs increase.

\section{The Need for Agency Coordination}

It would be easy, and truthful, to simply state that greater resources are needed, and that federal funding for Native American programs should be increased across the board. But careful analysis reveals that the underlying priorities and bureaucratic hurdles of the federal government are massive, imbued, hard to quantify, and thus difficult to change. The problems in Indian Country have been studied extensively, yet no coordinated, comprehensive federal effort has been made to audit spending and develop viable solutions. The result has been a patchwork of assorted programs, not a functioning results-oriented system with appropriate program delivery and tracking. Thoughtful analysis is needed followed by swift and decisive action oriented to a system overhaul, not a tune-up. These problems cannot be resolved through minor modifications to existing mechanisms.

While some agencies are more proficient at managing funds and addressing the needs of Native Americans than others, the government's failure is systemic. Although the purpose of this report was to review appropriations, not to evaluate program administration and effectiveness, the Commission notes several areas of jurisdictional overlap, inadequate collaboration, and a lack of articulation among agencies. The result is inefficiency, service delay, and wasted resources. For example, overlap in housing responsibilities between HUD, HHS, BIA, and USDA, according to some sources, lengthens efforts to build and repair homes in Native communities. ${ }^{2}$ Moreover, it is necessary that BIA and HUD maintain open lines of communication with respect to land title, so that individuals wishing to purchase homes and businesses seeking to develop land in Indian Country are not dissuaded by bureaucracy and burdensome paperwork.

Likewise, the responsibility for providing education to Native children is shared between DOEd and BIA. DOEd's role has essentially become one of funding rather than one of coordinating, overseeing, and ensuring equal educational opportunity. Rural and economic development, as broad categories, are shared among USDA, HUD, and BIA, as well as other agencies not discussed here. More sophisticated articulation between HHS and DOJ could eliminate criminal justice problems associated with

\footnotetext{
${ }^{2}$ National American Indian Housing Council, Too Few Rooms: Residential Crowding in Native American Communities and Alaska Native Villages, 2001, p. 37.
} 
illness. Fragmented funding and lack of coordination not only complicate the application and distribution processes, but also dilute the benefit potential of the funds.

\section{Inconsistent Reporting and Tracking}

As Commission staff discovered during the research phase of this study, tracking Native American expenditures governmentwide and within individual departments is complex, incomplete, and difficult. There is no uniform reporting requirement for Native American program funding. Thus, reviewing the voluminous appropriations legislation for each federal agency - and even then there is no guarantee that actual Indian expenditures are listed - is the only conceivable way to assess how much the government spends in total each year. Even individual agencies could not easily determine how much was budgeted and how much was spent. Commission staff had to contact multiple offices within the departments reviewed to construct the information in this report. This laborious challenge renders monitoring of federal spending too difficult. Moreover, federal funding of Native American services is too fragmented, making it difficult for tribal governments, much less the public, to navigate.

Included in the annual appropriations bills under the Department of Interior and Related Agencies is a table, "Federal Funding of Indian Programs," which lists funding by department. While this list provides a general overview of funding, it does not provide detail about specific allocations. In addition, because agencies self-report their expenditures, information availability varies across agencies. Some agencies include every program from which a Native American benefits, even if the program also benefits the general population. Other agencies only track funding for Native-specific programs; still others track grant programs, but cannot easily determine how much of a grant is actually distributed to tribes.

\section{Recommendations}

Recommendation 1: Native Americans have suffered too long from inattention and halfhearted efforts, and the crisis in Indian Country must be addressed with the urgency it demands. The federal government must take immediate steps to resolve the disparate living conditions that plague Indian Country. Enough studies, including this one, have concluded that the existing patchwork of service delivery is not working. The administration should establish a bipartisan, action-oriented initiative at the highest level of accountability in the government, with representatives including elected officials, members of Congress, officials from each federal agency that funds programs in Indian Country, tribes, and Native American advocacy organizations. The action group should be charged with analyzing the current system, developing solutions, and implementing change. This process must begin immediately with feasible objectives that can be accomplished as early as the next fiscal year.

The goals of the action group should include increasing Native American participation in government programs; fostering coordination among federal agencies; improving research and data collection on Native American populations and subpopulations; and involving the public and private sectors in improving the well-being of Native Americans.

Recommendation 2: All agencies that distribute funds for Native American programs should be required to regularly assess unmet needs for both urban and rural Native individuals. Such an assessment would compare community needs with available resources and identify gaps in service delivery. Agencies should establish benchmarks for the elevation of Native American living conditions to those of other Americans, and in doing so create attainable resource-driven goals. 
In addition, each federal agency that administers Native American programs should specifically and accurately document Native American participation in its programs and account for all projects and initiatives. This inventory will provide tribal governments and Native individuals with up-to-date information on the services and programs available and will enable agencies to identify and reduce program redundancies.

Recommendation 3: The Commission commends the Indian Health Service for the progress it has made to compare federal spending on Indian health care with that of other populations. The agency's Federal Disparity Index assessment has worthy elements for assessing unmet needs and as such should be replicated by other agencies. Tribal organizations and Native American advocacy groups have consistently monitored funding issues and unmet needs, and as such should be consulted when agencies develop measures so that the true needs of their constituencies are included. The results of such examinations should be used to prepare budget estimates, prioritize spending, and assess the status of programs. Congress should require and review unmet needs analyses annually as a component of each agency's budget justification.

Recommendation 4: All federal agencies that administer Native American programs, including those not addressed here, should be required to set aside money for infrastructure building that, when coordinated, will ensure that funds are spent more wisely. This will benefit both tribes and the agencies that need these basic installations to provide their services. Examples of needed infrastructure include roads, multipurpose buildings, utilities, and communications systems. Such a fund should be jointly managed by the Bureau of Indian Affairs, representatives from each contributing agency, and a coalition of tribal leaders or representatives from existing tribal organizations/councils. The contributing agencies should develop memoranda of understanding and other formal coordination mechanisms that outline precisely how the money will be spent.

Recommendation 5: Federal agencies should avoid instituting across-the-board budget cuts because Native American programs already make up such a small proportion of agencies' budgets. Any decrease magnifies the severity of already underfunded Native American programs. Rather than reduce funding across the board, agencies must honor the government's trust responsibility and the urgent needs of Native Americans. Ignoring unmet needs and legal obligations to tribes undercuts the ability of funds to solve problems. In addition, agencies must prepare budgets that account for the proportionality of Native American funding. As this study demonstrates, an increase in funds to an agency has not always resulted in increased spending power for Native American programs.

Recommendation 6: Native American funding programs should be situated within the federal agencies that have the requisite expertise, but agencies should continually improve processes for redistributing funds as necessary to other agencies or tribal governments. The Commission does not go so far as to recommend that all Native American funding be channeled through one source, such as the BIA, because dispersed budget authority reduces the risk that problems or mismanagement in one agency would adversely affect all services. However, the Commission recommends that funding for a single purpose be consolidated to reduce redundancy and clarify accountability. A system of centralized services, according to function, would reduce the government's redundancy and wasteful spending, and streamline the bureaucratic hurdles that often limit or delay tribal and individual participation in programs.

Consolidation of funds would further enable agencies to draw on all available resources, including those not specifically designated for Native Americans, such as those for rural communities and the operation of existing facilities (schools, health clinics, etc.). However, consolidation would require more vigilant tracking and consistent reporting methods on the part of all agencies. 
Recommendation 7: Self-determination ultimately requires that Indian nations govern their own resources. To the extent possible, programs for Native Americans should be managed and controlled by Native Americans. Past experiences reveal that many funds simply are not spent on their intended purpose. Distribution of funds to tribes will require close monitoring by the source agencies to ensure that funds are used as directed. However, the methods of distribution and monitoring must be established in consultation with Native Americans and tribal governments so that the trust fund mismanagement situation does not repeat itself. The federal government must determine the most effective and ethical means of disbursing funds to tribal governments and to directly assist Native peoples.

Recommendation 8: Federal appropriations must account for costs that are unique to Indian tribes, such as those required to build necessary infrastructure, those associated with geographic remoteness, and those required for training and technical assistance. Overall, more money is needed to support independent enterprise, such as through guaranteed loans that facilitate home and business ownership, and to provide incentives for lending institutions, builders, educators, and health management companies to conduct business on Indian lands. The federal government should develop widespread incentives to facilitate education and to promote the return of services to Indian communities. In doing so, it will promote economic development in Indian Country, which will eventually reduce reliance on government services.

In addition, the unique needs of non-reservation and urban Native Americans must be assessed, and adequate funding must be provided for programs to serve these individuals. Native Americans are increasingly leaving reservations, and their way of life, not always by choice but due to economic hardships. Yet, funding for health, education, housing, job training, and other critical needs of urban Native Americans is a low priority.

Recommendation 9: Congress should require that this review be taken further, to include an analysis of the spending patterns of every federal agency that supports Native American programs. Such a review should be done by either the Congressional Research Service, which already conducts regular assessments of selected agencies, or the U.S. General Accounting Office, which has the resources to do full-scale evaluations. In addition, an independent external contractor should audit fund management of all federal agencies distributing Native American appropriations. The audit should be comprehensive, cross-cutting, and include an assessment of program efficiency; an analysis of how agencies test or evaluate programs for effectiveness; solutions for more efficient coordination among agencies; and an action plan with target dates.

Recommendation 10: Each agency should have one central office responsible for oversight and management of Indian funds, and which prepares budgets and analyses that can be compared and aggregated across agencies.

Recommendation 11: The Office of Management and Budget (OMB) should develop governmentwide, uniform standards for tracking and reporting spending on Native American programs. Agencies should be required to include justifications for each Native American project, as well as justifications for discontinuation of projects, in annual budget requests. They should be required to maintain comprehensive spending logs for Indian programs, including actual grant disbursements, numbers of beneficiaries, and unfunded programs. Such information will facilitate future short-term and longitudinal analyses. 


\section{Toward Reform}

Measured by honor of funding commitments, none of the agencies reviewed has met its obligations to Native American tribes. Plans were made to reinforce the government's commitment in the late 1990s, but lost ground when budgets were cut. The government's failure has resulted in services that are of lower quality than those provided to other Americans and inequitable access to much-needed programs.

Federal law and policy already require tribal self-determination. Thus, new agreements and studies, unless they collect badly needed evaluation data so as to eliminate wasteful and burdensome agency redundancy, are not the priority. Conversely, swift and decisive action oriented to fulfilling existing federal responsibility must be taken. Clearly, Native Americans will achieve greater political empowerment and more influence in the political process when the federal government meets its financial obligations to them. Native Americans must be given the opportunity to be heard.

Insufficiencies have roots that lie deep in the past. Through monitoring of the type that this report provides, the Commission believes that Native peoples and federal agencies profit. The void that this study has identified, unless filled, renders laws and agreements with Native peoples little more than empty promises. If pursued now, focused federal attention and resolve to remedy the quiet crisis occurring in Indian Country would signal a decisive moment in this nation's history. That moment would constitute America's rededication to live up to its trust responsibility for its Native people. Only through sustained, systemic commitment and action will this massive federal responsibility be realized. 


\section{Glossary of Terms}

Actual funding. Dollar amount appropriated in the year discussed.

Adjusted funding. Dollar value after adjusting for inflation.

Appropriation. Legal authority for federal agencies to incur obligations and make payments for specific purposes.

Budget authority. The authority provided in law to enter into legal obligations that will result in immediate or future outlays of government funds.

Constant dollars. See adjusted funding. For the purpose of this report all inflation-adjusted figures are represented in constant 2003 dollars.

Current dollars. See actual funding.

Definite authority. A dollar amount in an agency's budget authority that is legislatively set. This definite authority may be an amount not to be exceeded.

Deflator. The formula used to calculate the inflation-adjusted value of a current dollar. For this report, the deflators used by the Office of Management and Budget in the Budget of the United States, Historical Tables, Fiscal Year 2004 (table 1.3, p. 26).

Discretionary funds. Funding authorized in an annual one-time appropriations act approved by the Congress and the President.

Full funding. When the total amount of funding requested and/or statutorily required for a program and its subprograms is appropriated.

Indefinite authority. The portion of an agency's budget authority that is subject to variable factors as outlined in its authorizing legislation.

Indian Country. Geographic regions encompassing reservations and trust lands within which Indian laws and customs and federal laws relating to Indians govern.

Mandatory funds. Funding authorized through permanent legislation rather than annual appropriations.

Outlays. The amount of money the government actually spends in a given fiscal year.

Program level. An agency's budget authority and its receivables, which may include payment for products, service, and interest.

Real funding/Real spending power. The amount of purchasing power of the dollar after adjusting for inflation.

Requested appropriations. The amount of funding proposed by the President based on an agency's past spending, its future estimates, and expressed priorities.

Set-aside. The portion of a fund that is reserved for a specific purpose. In this report, a set-aside refers to the portion of a larger fund that is earmarked for Native American programs. 
Subprogram. Specific grant or smaller program within a larger program.

Trust. Generally, the federal government's obligation to provide services and support to Native Americans in exchange for land and natural resources. It also refers to the government-togovernment relationship between tribes, as sovereign political bodies, and the federal government.

Trust fund. The collection of Individual Indian Money accounts managed by the Department of the Interior on behalf of the United States. The federal government acts as trustee of accounts, holding income from land leases on behalf of individual Native American beneficiaries. 